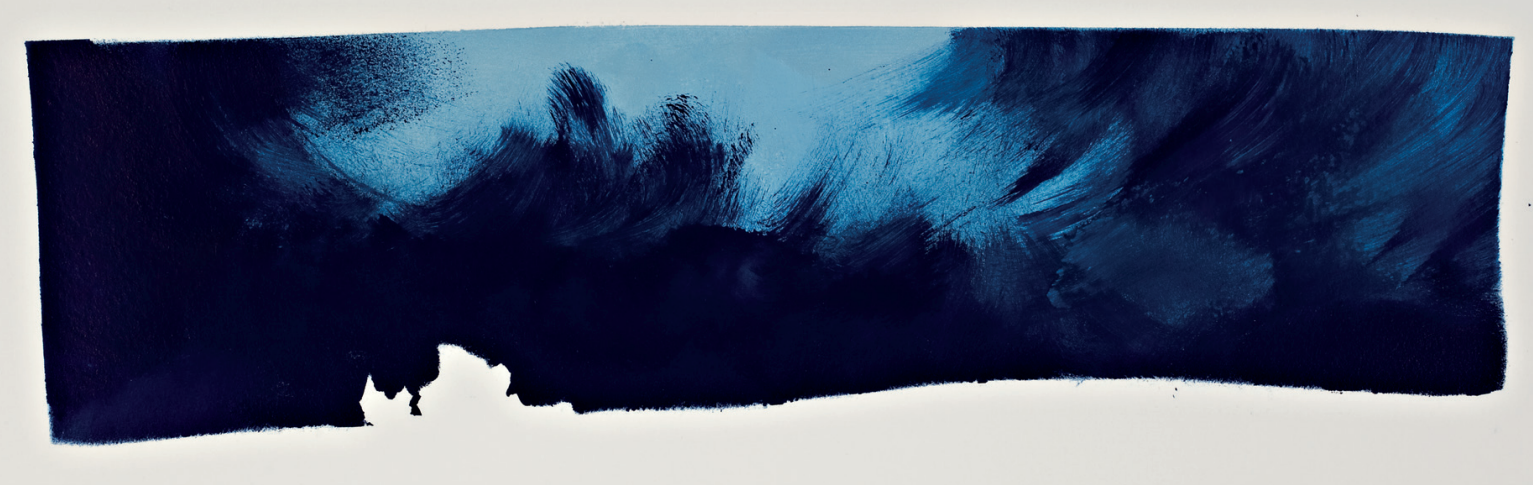

Advancement of benthic indicators and biomarker-based tools for biomonitoring and risk assessment in the Barents Sea region 
Advancement of benthic indicators and biomarker-based tools for biomonitoring and risk assessment in the Barents Sea region

Ariadna S. Szczybelski Ciordia 


\section{Thesis committee}

\section{Promotor}

Prof. Dr A.A. Koelm ans

Personal chair at the Aquatic Ecology and Water Quality Managem entGroup

Wageningen University \& Research

\section{Co-promotor}

Dr N.W. van den Brink

Associate professor, Sub-departm ent of Toxicology

Wageningen University \& Research

\section{$O$ ther members}

Prof. Dr H.H.M. Rijnaarts, Wageningen University \& Research

Prof. Dr A.J. Hendriks, Radboud University Nijm egen

Dr P.E.G. Leonards, VU Am sterdam

Dr M.J.J.E. Loonen, University of Groningen

This research was conducted under the auspices of the Graduate School for Socio-Econom ic and Natural Sciences of the Environm ent (SENSE) 


\title{
Advancement of benthic indicators and biomarker-based tools for biomonitoring and risk assessment in the Barents Sea region
}

\author{
Ariadna S. Szczybelski Ciordia
}

\section{Thesis}

subm itted in fulfilm ent of the requirem ents for the degree of doctor at Wageningen University by the authority of the Rector Magnificus, Prof. Dr A.P.J. Mol, in the presence of the

Thesis Com $m$ ittee appointed by the Academ ic Board to be defended in public on Monday 5 Novem ber 2018 at 1:30 p.m . in the Aula. 
Ariadna S. Szczybelski Ciordia

Advancem ent of benthic indicators and biom arkerbased tools for biom onitoring and risk assessm ent in the Barents Sea region,

240 pages.

$\mathrm{PhD}$ thesis, Wageningen University, Wageningen, the Netherlands (2018)

With references, with sum $m$ ary in frglish

ISBN: 978-94-6343-469-0

DOI: https://doi.org/10.18174/455054 
But that in the simple appreciation of a world not our own to define, that poised arctic landscape, we might find some solace by discovering the ki-lin hidden within ourselves, like a shaft of light.

- Barry Lopez - 


\section{CO NTENTS}

$1 \mathrm{G}$ eneral introduction...................................................................................................... 9

2 Bioaccumulation of polycyclic aromatic hydrocarbons, polychlorinated biphenyls and hexachlorobenzene by three Arctic benthic species from K ongsfjorden (Svalbard, Norway)

3 Bioaccumulation of polycyclic aromatic hydrocarbons by Arctic and temperate benthic species 61

4 Biomarker responses and biotransformation capacity in Arctic and temperate benthic species exposed to polycyclic aromatic hydrocarbons 107

5 Avoidance tests as a tool to detect sublethal effects of oil-impacted sediments 151

6 Synthesis 187

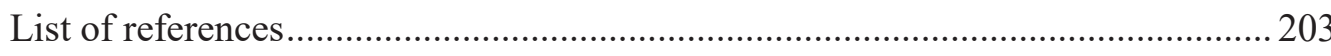

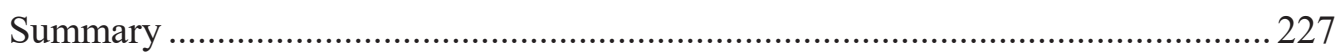

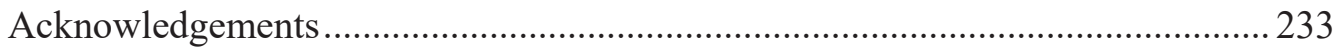

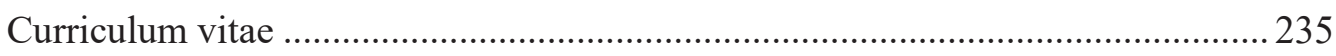

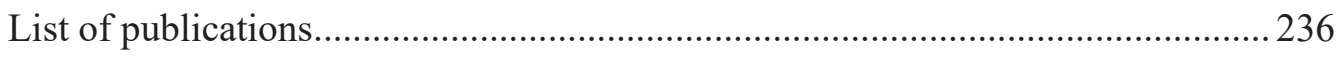

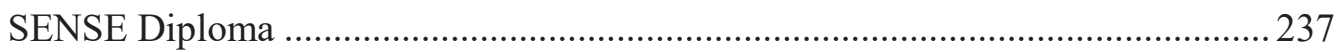


$1 \mathrm{G}$ eneral introduction 


\section{Chapter 1}

The Arctic Ocean is subject to a substantial clim ate change[1], causing Arctic $m$ arine ecosystem $\mathrm{s}$ to exhibit particularly fast changes in the com ing decades[2,3]. Sea ice loss and an extended open water period within Arctic $m$ arine areas are expected to contribute to increased hum an activities such as oil and gas $(O \& G)$ production, com $m$ ercial fisheries and tourism developm en $\{4,5]$. This raises a global concern about Arctic $m$ arine oil pollution [6,7] and its long-term im pacts [8], based on experiences and environm ental im pacts from previous oil spills in the Arctic or elsewhere $[9,10]$. Awareness is also reinforced by the vast am ounts of bunker fuel on board ships curiently transiting International Maritim e Organization Arctic waters being operated on heavy fuel oil [11], salient difficulties during oil spill response such as rem oteness, seasonal darkness, stronger winds and currents, $\mathrm{m}$ ore fragm ented sea ice and a lack of effective oil spill response $m$ ethods for icy conditions $[12,13]$. Consequently, sustained and adequate long-term $m$ onitoring of the im pacts of oil spills on Arctic ecosystem s and developm ent of plans for m itigation before and after Arctic oil spills should be im plem ented[14-16].

Current environm entalrisk assessm ent procedures contain uncertainties on the potential long term effects of oil spills and operational discharges of produced water in the Arctic[17]. Environm ental risk assessm ent com bines exposure assessm ent and chem iespecific hazard data. Oil spills $\mathrm{m}$ ay pose an acute risk to the environm at, with ecological consequences being highly dependent on the type of oil, size of spill, environm ental characteristics of the habitat, selection and effectiveness of em ergency response system \$16]. Risk assessm ent of O\& $\mathrm{G}$ and shipping activities also needs to include long-term effects of continuous exposure to drilling waste and produced water [18].

Environm ental im pact assessm ent procedureshould delineate oil pollution sources, transport $m$ echanism s, routes and duration of exposure to Arctic species or habitats prior to the im plem entation of forecasting $\mathrm{m}$ ethods to predtoO\& $\mathrm{G}$ environm ental im pacts. Arctic characteristics affecting the environm ental fate and effects of oil related chem icals $\mathrm{m}$ ay result in different exposure scenarios between Arctic and tem perate species. Therefore, environm ental $\mathrm{m}$ onitoring tools should relyon the identification of factors that are critical for the exposure to oil related chem icals and developm ent of subethal effects in Arctic biota. Such factors $\mathrm{m}$ ay be used to define acceptable environm ental assessm ent criteria and $\mathrm{m}$ onitoring $\mathrm{m}$ ethods forlte early detection of O\& $\mathrm{G}$ environm ental im pacts in the Arctic. 
For any species or group of species to be an effective indicator of $O \& G$ related chem icals, the abovem entioned factors should $\mathrm{m}$ eet the following criteria:

1. Its response is sensitive to changes in the chem ical concentration;

2. Its response is specific and causally related to the chem ical exposure;

3. Its response is adequate given the anticipated concentration of the chem ical[19];

4. The species' uptake/elimination of the chemical can be quantified;

5. The toxic effects of the chem ical can be $m$ easured/interpreted.

For the specific purpose of the thesis, biological indicators (bioindicators) are defined as biological species which $\mathrm{m}$ ay be affected by the exposure to a given O\& $\mathrm{G}$ target chem ical at different levels of biological organization and under realistic O\& G exposure scenarios. In addition, bioindicators $\mathrm{m}$ ay present different functional traits and habitat choices so that their com bined use $\mathrm{m}$ ay indicate different levels of stress for different ranges of environm ental conditions and/or exposure to an O\& G chem ical group. Since adaptations of Arctic $m$ arine individuals to their environm ent underlie their sensitivity and vulnerability to O\& $G$ chem icals, the genetic diversity and phenotypic plasticity of species traits influencingthe com bined effect of natural stressors (e.g., ocean acidification) and O\& G waste exposure should be reflected by regional im pact $\mathrm{m}$ onitoring. This ensures that bioindicators of potential pressures arising from $\mathrm{O} \& \mathrm{G}$ activities are identified, and that our $\mathbf{n d e r s t a n d i n g}$ of how certain ecological attributes increase resilience of Arctic $\mathrm{m}$ arine ecosystem $\mathrm{s}$ is im proved and used to develop oil spill restoration plans.

\section{Chem ical characterization and environm ental fate of offshore oil and gas waste in the Arctic with special em phasis on the Barents Sea region}

Waste $m$ aterials produced by offshore $O \& G$ activities that $m$ ay be discharged into the ocean are water-based drilling m uds (WBM) and cuttings, syntheticbased m ud (SBM) cuttings, treated produced water $(\mathrm{PW})$, treated sanitary and dom estic waste, deck drainage, oncethrough fire water and non-contact cooling water (Figure 1). WBM are form ulated $\mathrm{m}$ ixtures of clays, natural and synthetic organic polym ers, $m$ ineral weighting agents, and other additives, all dissolved or suspended in freshwater, saltwater, or in brine (Table 1). The com position of WBM m ay vary during drilling of a single well because different additives $\mathrm{m}$ ay be required to drill different well sections through varying geological form ations[20]. WBM cuttings that are discharged to the ocean tend to accum ulate at seafloor level downstream from the discharge source at distances of about $100 \mathrm{~m}$ to $\ngtr \mathrm{km}$. SBM cuttings do not 


\section{Chapter 1}

disperse on contact with sea water and settle rapidly when discharged, m anly exposing the (local) benthic ecosystem [21].

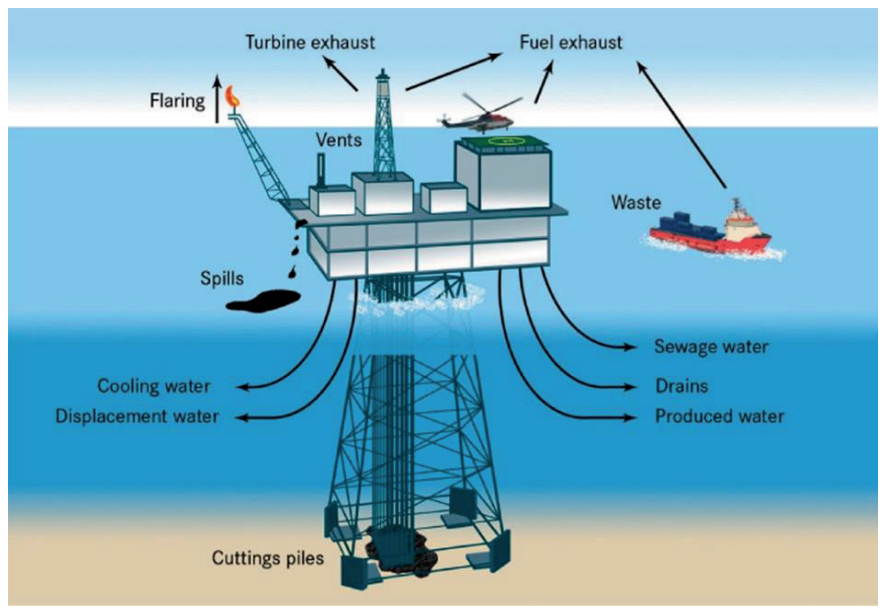

Figure 1. Offshore O\& G waste discharges and air em issions depiction.

Sewage water includes industrial household and sanitary sewage in com pliance with MARPOL 73/78 Annex V. Drains include ballast water, storm/rain water and other liquid waste in com pliance with MARPOL 73/78 Annex I, regulation 39. Produced water (PW), cutting piles (WBM attached to WBM cuttings and SBM cuttings, if allowed) and displacem ent waterdischarges are in com pliance with OSPAR Decision 2000/3. Em issions to air shall be in com pliance with the provisions of MARPOL 73/78 Annex VI. Shipping discharges to sea shall be in com pliance withthe provisions of MARPOL 73/78 Annex I-V. Source: http://www.ospar.org/workareas/oic/chem icals

Table 1. Functional categories of additives used in WBM to im prove drilling perform ance and exam ples of chem ical products as provided by the International Association of Oil and Gas Producers [20].

Functional Category of Exam ples

Additives

\begin{tabular}{ll}
\hline Weighting m aterials & barite, calcium carbonate, ilm enite or hem atite \\
Thinners & lignite, lignosulfonates, polym ers \\
Filtrate reducers & clay, lignite, polym ers, starch \\
Lost circulation & inert soluble solids (e.g., calcium carbonate, ground nut shells, graphite, \\
& m ica and cellulose fibres) \\
Shale control & soluble salts (e.g., KCl), am ines, glycols \\
Bactericides & glutaraldehyde, triazine disinfectants \\
Pipe-freeing agents & water-based lubricants, enzym es, surfactants \\
Corrosion inhibitors & am ines, phosphates \\
Viscosifiers & clay, organic polym ers \\
Flocculants & inorganic salts, acrylam ide polym ers \\
pH control & inorganic acids and bases (caustic soda) \\
Lubricants & water-based lubricants, glycols and beads \\
Em ulsifiers, surfactants & detergents, soaps, organic fatty acids \\
Defoam ers & alcohols, silicones, alum inium stearate, alkyl phosphates \\
Calcium reducers & sodium carbonate, bicarbonate, polyphosphates \\
Tem perature stability & acrylic or sulfonated polym ers, lignite, lignosulfonate \\
\hline
\end{tabular}




\section{Chapter 1}

$\mathrm{PW}$ is a com plex m ixture of dissolved and particulate organic and inorganic chem icals (Tables 2 and 3). Naturally occurring com pounds that ae dissolved or dispersed include inorganic salts, $\mathrm{m}$ etals, radioisotopes, and a wide variety of organic chem icals, $\mathrm{m}$ ainly polycyclic arom atic hydrocarbons (PAHs). Although these com pounds m ay occur naturally, local concentrations after a spill $\mathrm{m}$ ay exceed natural concentrations by several orders of $m$ agnitude, creating a nonnatural situation. Much of the petroleum hydrocarbons discharged to the ocean in properly treated PW are dissolved low-m olecularweight (LMW) PAHs and sm aller am ounts of saturated hydrocabons. Because PW treatm ent is not always optim ally effective, treated PW usually still contains som e dispersed oil which includes high-m olecular weight (HMW), less soluble saturated and arom atic hydrocarbons.If PW is discharged to shallow waters, som e m tals and HMW arom atic and saturated hydrocarbons $\mathrm{m}$ ay accum ulate in sedim ents near the PW source, with an increasing trend observed for com pounds with a relatively high octanol-water partitioning coefficient $\left(\mathrm{K}_{\mathrm{ow}}\right)$. In well-m ixed waters, high concentrations of saturated hydrocarbons and PAHs in sedim ents som etim es can be observed as far as hundreds of $m$ eters from the PW source[14,22,23].

Table 2. Concentration of naturally occurring organic chem icals in produced water worldwide as provided by Neff [24], and heavy m etals and radioisotopes in produced water from he Norwegian Continental Shelf as provided by Neff [24] and the Norwegian Radiation Protection Authority [25].

\begin{tabular}{lc}
\multicolumn{1}{c}{ Natural chem ical } & Treatm ent conc. $(\mathrm{m} \mathrm{g} / \mathrm{L})$ \\
\hline Total organic carbon & $\leq 0.1->11,000$ \\
Total organic acids & $\leq 0.001->10,000$ \\
Total saturated hydrocarbons & $17-30$ \\
Total benzene, toluene, ethylbenzene and xylenes (BTEX) & $0.068-578$ \\
Total polycyclic arom atic hydrocarbons (PAH) & $0.04-3.0$ \\
Total steranes/triterpanes & $0.14-0.175$ \\
Ketones & $1.0-2.0$ \\
Total phenols (prim arily $\mathrm{C}_{0}-\mathrm{C}_{5}-$ phenols) & $0.4-23$ \\
Metals (m ainly Barium ) & $107,000-228,000(\mu \mathrm{g} / \mathrm{L})$ \\
Radioisotopes (m ainly ${ }^{226} \mathrm{Ra}$ and $\left.{ }^{228} \mathrm{Ra}\right)$ & n.d. $-567(\mathrm{pCi} / \mathrm{L})$ \\
\hline n.d.: not detected. &
\end{tabular}




\section{Chapter 1}

Table 3. Sum $\mathrm{m}$ ary of additives in offshore produced water provided byZheng et al. [26].

\begin{tabular}{llc}
\multicolumn{1}{c}{ Function } & \multicolumn{1}{c}{ Offshore chem ical class } & Treatm ent conc. (ppm) \\
\hline Corrosion inhibitor (acid) & $\begin{array}{l}\text { Am ine im idazolines } \\
\text { Am ine salts } \\
\text { Quaternary am m onium salts } \\
\text { Nitrogen heterocyclics }\end{array}$ & $25-100$ \\
\hline Corrosion inhibitor (oxygen) & $\begin{array}{l}\text { Am m onium bisulfite } \\
\text { Bactericide }\end{array}$ & $\begin{array}{l}\text { Quaternary am ine salt } \\
\text { Am ine acetate } \\
\text { Gluteraldehyde }\end{array}$ \\
\hline Hydrate inhibitor & $\begin{array}{l}\text { Methanol } \\
\text { Ethylene glycol }\end{array}$ & $10-200$ \\
\hline Dehydration & Triethylene glycol & n.a. \\
\hline Scale inhibitor & $\begin{array}{l}\text { Phosphate esters } \\
\text { Phosphonates }\end{array}$ & n.a. \\
\hline Em ulsion breaker & $\begin{array}{l}\text { Oxyalkylated resins } \\
\text { Polyglycol esters } \\
\text { Sulfonates }\end{array}$ & $3-10$ \\
\hline Solid rem oval & $\begin{array}{l}\text { Polyam ine } \\
\text { Quaternary polyam ine }\end{array}$ & $10-200$ \\
\hline
\end{tabular}

n.a.: not available.

Am ong all pollutants released during O\& G drilling and production, alkylphenols (APs) and PAHs are seen as potential causes of long-term biological effects[23,27-29] although there is high variability in, for instance, $\mathrm{PW}$ com position between different fields and over drilling tim e (Table 2). Prolonged O\& G waste discharges could have a cum ulative effect on chronically exposed Arctic biota and their im pacts could be particularly relevant for ecosystem com ponats vulnerable to oil spills, such as benthic system s[30,31], since they $m$ ainly accum ulate hydrocarbons from sedim ents to which persistent fractions of oil rem ain adsorbed. Despite their relevance, long-term AP and PAH effects on benthic populations or com $\mathrm{m}$ unities at concentrations found in PW effluents are basically unknown[32] and there are scarce $m$ eans to evaluate their longterm im pacts on the $m$ arine environm ext 18,33$]$.

Besides, the effects of long-term exposure of Arctic benthos to oil or O\& G waste com ponents could be enhanced by increased prim ary prodictivity in seasonal ice regions where PAHs $\mathrm{m}$ ay be absorbed by phytoplankton, which in turn serves as $\mathrm{m}$ ajor food source for benthic species [34-37]. Furtherm ore, exposure to oil or O\& G waste $m$ ay be aggravated by in ited protein function (e.g., enzym atic detoxification) of benthos due to a relatively low tolerance of (sub-)Arctic tem peratures (i.e., $>5^{\circ} \mathrm{C}$ ) in polar ectotherm $\mathrm{s}[38,39]$. Chronic im pacts of O\& $\mathrm{G}$ waste discharge on Arctic benthic system s could eventually result in a reduction of the productivity of the Arctic $\mathrm{m}$ arine ecosystem since benthic system $\mathrm{s}$ are $\mathrm{m}$ ainly responsible for 


\section{Chapter 1}

carbon and nutrient recycling [30] and they form an im portant food source for $\mathrm{m}$ any top predators.

Because of the im portant role of benthic com $m$ unities within the Arctic $m$ arine ecosystem and their susceptibility to O\& G pollution, the scientific goalsof the current thesis focused on the Barents Sea region which is characterized by the highest benthic species diversity am ong the different Arctic seas [30]. Major gaps on the physical and biological conditions of the Barents Sea seabed currently prevent the integration of baseline knowledge about the benthic ecosystem in $\mathrm{O} \& \mathrm{G} \mathrm{m}$ onitoring programes and environm ental im pact assessm en[40-42].

In the following sections, I will justify and underpin the selection of PAHs and m odel Arctic benthic invertebrate species from the Svalbard inshore region as indicators for chem ical and biological pressures arising from O\& G activiies in the Barents Sea benthic system .

\section{Polycyclic arom atic hydrocarbons as oil and gas target chem icals}

PAHs are one of the m ain com ponents of crude oil and can be classified into (1) LMW PAHs which are highly toxic to aquatic organism s and highly volatle typically rem aining in the environm ent for hours to days following a spill, and (2) HMW PAHs which are less volatile and degradable, and are associated with chronic effects in biota due to their persistence in the environm ent[43]. PAHs have both natural and anthropogenic sources which overlap, particularly for com bustion, and processes such as diagenesis (i.e., alteration of sedim ents into sedim entary rock) can m odif sedim ent PAH distributions over tim e. In the Arctic Ocean, relatively high atm ospheric concentrations and increasing deposition of PAHs with increasing latitude have been attributed to com bustion of biom ass and/or coa[44]. Therefore, the environm ental fate and effects of anthropogenic PAHs m ust be evaluated against a site specific background of natural PAHs and a broad range of hydrocarbon indicators needs to be considered in order to define sources, transport and sedim entary persistence of PAHs[45].

Once released into the ocean, PAHs are subject to partitioning processes including adsorption, where the hydrocarbon attaches to the surface of a solid or other interface, and absorption, where the chem ical partitions into an (a)biotic com partm en[46]. Understanding the distribution or partitioning of PAHs between the dissolved phase, aquatic particles and sedim ent is crucial for the determ ination of fate and bioavailability $\Subset$ PAHs to $m$ arine biota, as this will strongly affect the environm ental fate of PAHs and $\mathrm{m}$ echanism $\mathrm{s}$ and $\mathrm{m}$ agnitude of exposure of aquatic organism s to PAHs[47,48]. Sim ilarly, PAH accum ulation in organism s 


\section{Chapter 1}

will be affected by PAH desorption rates from particles in biota digestive tissues and $\mathrm{m}$ etabolic rates that degrade or elim inate PAHs.

\section{Environm ental fate of PAH s: sorption to sedim ent and bioavailability}

The fate and persistence of petroleum in $\mathrm{m}$ arine system $\mathrm{s}$ are artrolled by physical, chem ical and biological properties and processes that subsequently m odify petroleum im pact. All these properties and processes are driving the weathering of oil, which however also depends on factors such as tem perature, light conditions and water m ixing by, for instance, wind. A key factor of oil weathering is based on the viscosity of the oil $\mathrm{m}$ ixture, which largely affects its tendency to spread out on surfaces [49]. Since cold tem peratures can increase the viscosity of oil, the resulting spreading of oil under Arctic conditions $m$ ay be lower than expected and so are the evaporation of volatile com ponents from oi[49,50] and from the water accom $m$ odated fraction of som e fuel oil[51]. This $m$ ay delay oil weathering and biodegradation [52] and increase PAH sorption affinity [46], particularly near river runoff sources where alluvium s of finely dispersed $\mathrm{m}$ aterials would sequestrate the suspended fractions of oil.

Desorption rate constants of PAHs from sedim ents contam inated with petroleum ainversely correlated with the logarithm of $\mathrm{K}_{\text {ow }}$ of the $\mathrm{PAH}$ com pound and directly correlated with its aqueous solubility $[53,54]$. PAHs associated with dissolved organic $\mathrm{m}$ atter (colloidal; DOC) behave like dissolved PAHs, whereas PAHs associated with suspended organic $\mathrm{m}$ atter will usually settle. They readily desorb from DOC, striving at an equilibrium between water, DOC, suspended and settled particles, defined by organic carbon norm alised partition coefficients $\left(\mathrm{K}_{\mathrm{oc}}\right)$. However, when PAHs rem ain adsorbed to sedim ent for long periods, their desorption rate will decrease since prolonged contact tim e of PAHs with organic $m$ aterials $m$ ay lead to increased $K_{b c}$ values over tim e[55]. This 'ageing' phenomenon effectively decreases the bioavailability of adsorbed PAHs [48].

Assessm ent based on bioavailability is considered a useful tool for the risk evaluation of contam inated sites. PAH bioavailability can be estim ated from PAH bioaccum ulation which results from PAH uptake by anorganism and subsequent chem ical excretion after digestion and $\mathrm{m}$ etabolism . Uptake of hydrocarbons in target tissues (bioavailability) occurs from sedim ents, suspended particulate $\mathrm{m}$ atter, the water colum $\mathrm{n}$, or through the diet, depending on the trophic level and ecological lifestyle of the organism [56]. In general, bioaccum ulation is $\mathrm{m}$ easured in order to (1) determ ine contam inan\$pecific bioavailability (for non-m etabolised 


\section{Chapter 1}

contam inants), (2) identify possible causative agent(s) of toxicity, (3) relate body residues to predator-prey accum ulation values (biom agnification factors) and (4) assess/predict effects of chronic, low-level exposures [57].

Under environm entally realistic PAH exposure scenarios, dealing with the fourth objective $\mathrm{m}$ ay seem com pelling. Since PAHs exert toxic effects following $\mathrm{m}$ etabolism, PAH body residues in organism $\mathrm{s}$ with low $\mathrm{m}$ etabolic rate such as cold stenotherm al bivalves will ainly reflect PAH bioavailability [58]. For organism $\mathrm{s}$ with a higher $\mathrm{m}$ etabolic rate, $\mathrm{m}$ easurem ent of parent PAH com pounds is difficult due to low concentrations, hence PAH m etabolic products need to be analysed to determ ine a relationship between bioaccum ulation and toxicity. However, toxicity from bioaccum ulation will also depend on the prior history of organism exposure and the differences in organism sensitivity. Thus, both bioaccum ulation of PAHs (and their derivatives) and toxic effects should be sim ultaneously reported in benthic organism s exposed to PAHs in order to identify any likely tolerance m echanism s or sensitivity under low PAH exposure level [59].

\section{Arctic benthic invertebrates as oil and gas bioindicators}

In coastal environm ents, where oil is m ost likely to strand and accum ulate, local biota will be subject to long-term im pacts at source point or in surrounding areas after oil rem obilization. In these coastal areas, or hydrodynam ic system s, a causal link between an increase of PAHs in suspended solids and higher PAH bioavailability is suggested due to frequent sedim ent resuspension and ageing $[60,61]$. This process $\mathrm{m}$ ay be enhanced by thephysical disturbance of sedim ent and increased riverine input of terrestrial PAH sources within inshore distance to land $(<200 \mathrm{~m})$. Freshwater drainage with terrigenous particles $\mathrm{m}$ ay, in addition, create steep gradients of sedim entation and salinity[62] which generally underlie a shift from filter to (sub-)surface-deposit feeders within the benthic com m unity. Allowing for the coexistence of different functional groups along such sm alkscale gradients, a com prehensive understanding of the influence of species traits on PAH uptake and selection of bioindicators $\mathrm{m}$ ay be prom oted.

Many polar benthic organism s typically display $K$ strategies [63], such as reduced developm ent and lower resource thresholds. In low water energy zones, absence or tem porary drifting of larval stages and selective feeding m ode would cause benthic invertebrates to be constantly exposed to local PAH sources and their possible PAH uptake routes could be m ore easily defined. Additionally, am ong true residents, ectotherm s m ay show a high vulnerability 


\section{Chapter 1}

to increasing tem peratures with greater fluctuations in their abundances on an inter-annual scale, depending on their recent recruitm ent[64]. Such ectotherm s $\mathrm{m}$ ay be far $\mathrm{m}$ ore vulnerable to cum ulative, but relaively $m$ inor im pacts causing local extinctions such as the com bined effect of rising tem peratures, food shortage and oil spill incidents.

\section{Validation of long-term PAH exposure indicators in Arctic benthic invertebrates}

In the Arctic, developm ent of offshoreO\& $\mathrm{G}$ has undergone extensive technological and engineering advances that have enabled the industrial sector to operate safe and efficiently from a hum an and econom ic perspective65]. One im portant aspect derived from such advances is the prioritization of early detection of environm ental effects of anthropogenic pollution sources, notably effects derived from release of com pounds included in the List of Substances/Preparations Used and Discharged Offshore that are Considered to Pose Little or No Risk to the Environm ent (PLONOR)[66]. The PLONOR list encom passes com pounds for which an array of ecotoxicological properties has been evaluated according to the Harm onized Offshore Chem ical dtification Form at (HOCNF)[67] and set against a suite of validity criteria in order to ensure environm ental risks are $\mathrm{m}$ inim ized during operational discharges. In the Lofoten-Barents Sea region, the developm ent of O\& G resouces is perm itted under a strict regulatory policy of zero discharge ofoil-based m ud (OBM) and SBM cuttings $[68,69]$, whereas $m$ ost of the additives used in WBM are either PLONOR substances or if non-PLONOR their use is restricted to em ergency situations

For the scientific com m unity, there is one key question about current ecotoxicological data validation in the Arctic, which is whether the actual param eters used in HOCNF classification criteria need to be adjusted for this region. This question is $m$ otivated by the fact that low tem peratures and regional physiological adaptations in Arctic species $m$ ay give a difference in sensitivity to oil com ponents of Arctic ecosystem s when com pared to nonArctic system s. It has been shown that in general, differences in sensitivity to oil or PW com ponents between Arctic and non-Arctic test species are sm all[70-72], the form er ones including m ainly boreal species with either a planktonic or nektonic adult stage. However, factors such as O\& G waste discharge conditions, ecological seasonal variations or a delayed $\mathrm{m}$ anifestation of toxicity in polar environm ents as recently suggested[73], could play an im portant role in establishing differences between the susceptibilities of both regional groups in the long term .

Param eters such as bioaccum ulation and biotransform ation are currently included in national or regional biom onitoring program $m$ esf the $m$ arine environm enf 74$]$, and they have been 


\section{Chapter 1}

com pared across a wide range of tem perate aquatic system $\mathrm{s}$ and benthic species, enabling us to $\mathrm{m}$ ake a read across between Arctic and tem perate species. In this thesis, both param eters are used as part of an evaluating approach for the identification of long-term PAH exposure indicators in Arctic benthic species. In addition, the thesis evaluates the sensitivity of behavioural indicators in benthic m odel species to reflect on their potentid use for the prediction of sublethal effects of oil from the perspective of Arctic benthic biota.

\section{PAH bioaccum ulation from sedim ent: biotsedim ent accum ulation factors (BSAFs) for}

\section{Arctic benthos}

Bioconcentration of PAHs from water is directly proportional to their respective $\mathrm{K}_{\mathrm{ow}}$ value, whereas bioaccum ulation from sedim ents and food involves an interm ediate step in which PAHs desorb from the solid $m$ atrix and partition into the lipid tisses of the organism via the aqueous gut content. Bioaccum ulation m odels generally assum e that (1) both uptake and elim ination routes are regulated by passive partitioning and will finally result in steady-state conditions and that (2) there is no biological $\mathrm{m}$ etabolism once the PAH is absorbed. Bioaccum ulation from ingestion has been neglected by traditional m odels suchsathe Equilibrium Partitioning Theory (EPT) [75]. The EPT $m$ ethod assum es that organic chem icals such as PAHs partition between the sedim ent organic carbon and biota lipid phase and that there is an equilibrium. However, the use of EPT m ethodology and the validity of its extrapolation to sedim entdwelling organism s have been questioned because of the large variability in tissue PAH concentrations across species and environm ental conditions $[56,76,77]$. Hence, bioaccum ulation processes are not solely explained by passive partitioning.

In both filter- and deposit-feeding organism s, PAHs arem ainly accum ulated via food intake as these chem icals are generally adsorbed on dissolved and particulateorganic $\mathrm{m}$ atter (OM). Because of the high affinity of PAHs for (sedim ent) condensed carbon (e.g.,black carbon; $\mathrm{BC}$ [ [78], there is an inverse relationship between the concentration of $\mathrm{BC}$ in sedim ents and the bioavailability of PAHs in sedim ents to $m$ arine organism 579]. Additionally, the relative contribution of water, food and sedim ent PAH sources to the total body burden greatly varies from one species to another $[56,76,77,80]$. Within the EPT context, the estim ation of a PAH com pound concentration in a certain species $\mathrm{m}$ ay be obtained by $\mathrm{m}$ ultiplying its sedim ent concentration by an em pirically derived biotasedim ent accum ulation factor (BSAF) for that sam e PAH, species and sedim ent quality/com position. In practical term s, the observed 


\section{Chapter 1}

variability in PAH concentrations requires a broad interpretation since the bioavailability of PAHs will be m odified by the species behaviour and the com positia of their sorbent.

The BSAF has been used as a m etric to evaluate the bioaccum ulation of contam inants from sedim ent and has been com pared across a wide range of aquatic ecosystem $556,80-83]$. The use of the BSAF concept assum es that the concentration of chem icals in organism $\mathrm{s}$ is a linear, non-threshold function of the concentration in sedim ent.However, assum ptions of steady state conditions and absence of $\mathrm{m}$ etabolism $\mathrm{m}$ ay not always be suitable, particularly if food sources are predom inantly waterborne or if PAHs are effectively m etabolised after sum m er periods of intense foraging. In the Arctic, BSAFs for organic pollutants have been barely reported for benthic biota under field or laboratory conditions $[84,85]$, and have never been reported for PAHs in benthic biota.

\section{A PAH biotransform ation approach: biom arkers of PH exposure and pyrene m etabolites in Arctic benthos}

Biom arkers of chem ical exposure $\mathrm{m}$ ay be useful as estim ators of chem ical stress to $\mathrm{m}$ onitor trends in ecological im pacts of O\& G activities[86,87]. For instance, arom atic xenobiotics $\mathrm{m}$ ay enhance the production of intracellular reactive oxygen species (ROS) through induction of the cytochrom e P450 system (CYP). CYP is a m ultigene fam ily of haetmontaining enzym es, which catalyse a variety of oxidative reactions, including hydroxylation, epoxidation, dealkylation, deam ination, sulfoxidation, and desulfuration (i.e., Phase I). During these reactions, the lipophilicity of the xenobiotic is lowered by the addition of a polar functional $\mathrm{m}$ oiety, which often $\mathrm{m}$ akes the $\mathrm{m}$ etaboite $\mathrm{m}$ ore hydrophilic and, in $\mathrm{m}$ ost cases, ready for further conjugation and/or excretion. Metabolites produced in Phase I reactions can be elim inated or covalently conjugated to various endogenous com pounds (e.g., reduced glutathione, glucuronic acid, sulfate) to further decrease their lipophilic properties. Such reactions, com m only known as Phase II, are catalysed either by glutathione transferases (GSTs), uridine-diphosphate-glucuronosyl-transferases (UDPGTs), or sulfotransferases (STs), usually yielding water-soluble products that can be readily excreted. Suites of biom arkers have been successfully applied at low levels of biological organization in com bination with chem ical body residues in fish and invertebrates[74,88,89]. However, the use of biom arkers also has been criticized as a result of the lack of a clear ecological relevance [86] and of difficulty in data interpretation due to the influence of confounding factors [90] or lack of baseline values [91]. 


\section{Chapter 1}

The $\mathrm{m}$ ajor trait that could enhance oxidative stress sensitivity in polar species is the elevated unsaturation level in $\mathrm{m}$ em brane lipids[92]. A higher percentage of the polyunsatured fatty acid (PUFA) represents an im portant $\mathrm{m}$ echanism by which polar ectotherm $\mathrm{s} \mathrm{m}$ aintain biological $\mathrm{m}$ em brane structural and functional properties against low tem peratureSince PUFAs are highly susceptible to ROS attack, and high unsaturation levels enhance the velocity and propagation of lipid radical chain reactions, the difference in fatty acid com position increases the vulnerability of polar organism s to oxidative stres. PAH $m$ etabolites $m$ ay, in addition, exert preoxidant effects through the redox cycle, a well-known source of chem ically-m ediated ROS generation[93], while m etabolites containing an epoxide $m$ ay be $m$ utagenic and/or carcinogenic or even inhibi som e CYP com ponents94]. From a practical point of view, the analysis of PAH $\mathrm{m}$ etabolites in polar benthos $\mathrm{m}$ ay facilitate the definition of acceptable oxidative stress thresholds since $\mathrm{m}$ etabolic responses $\mathrm{m}$ ay not rely a a large variety of hom eostatic controls and feedback m echanism $s$ as in the case of changes in enzym atic induction (i.e., gene expression and protein production), which ensures their m eaningful interpretation[95].

\section{Behavioural response approach: avoidance of Distillate Marine grade A (DMA) oil-spiked sedim ent}

Active spatial avoidance ('escape') of contaminated sediment relates to the ability of an organism to detect toxicants via olfaction or taste and to $\mathrm{m}$ ove to a lesser contam inated area [96]. Such behaviour can be up to 1000 tim es m ore sensitive than conventional lethal endpoints (e.g., LC50), and it may also potentially reflect changes at a population level [97]. Am ong benthic invertebrates, am phipods have been extensively used in avoidance assays $[98$ 101] since they are equipped with a sensory system and they form an im portant food source for benthic fishes and other organism s. To date only few studies have addressed avoidance behaviour of oil-contam inated sedim ent by benthic am phipods, all of which were restricted to tem perate $\mathrm{m}$ arine or estuarine species such asCorophium volutator or Melita plumulosa.

In the Arctic, exposure to the water-soluble fraction (WSF) of oil revealed little m ortality in sea-ice am phipods (i.e.,Gammarus wilkitzkii), although biom arker results indicated subethal effects after exposure to WSF [102]. However, oil toxicity in pelagic am phipods $m$ ay be quickly dam pened due to considerable evaporation and dissolution of oil in the water colum $n$. This $m$ ay not be thecase in the water-sedim ent interface where $m$ icrobial degradation of oil under Arctic conditions [103] $\mathrm{m}$ ay result in persistent and localised sedim ent oil sources. 


\section{Chapter 1}

These $m$ ay trigger an escape response in benthic am phipods, while their response to lethal concentrations $\mathrm{m}$ ay be slower than avoidance as previously observed inam phipods exposed to the water-accom m odated fractionof oil $[104,105]$.

Since heavy fuel oils are being gradually replaced with $\mathrm{m}$ arine distillate fuel oils (e.g., DMA) where increased $\mathrm{m}$ arine traffic is expected[106] and the organic fraction of distillate fuels $\mathrm{m}$ ight be able to persist sufficiently long to adsorb to sedim ent and cause toxicity on a sim ilar scale than heavier fuels [51,107], escape by Arctic benthic am phipods from oilspiked sedim ent could becom e a sensitive tool forthe early detection of oil sublethal effects in benthic com m unities[108,109]. So far, studies have been perform edon the toxicity of diesel in sedim ent to polar benthic species such as the ophiuroidOphiura crassa [110] and the am phipodGammarus setosus [111], but their ability to avoid oil-contam inated sedim ent has never been addressed under field or laboratory conditions. Integrating escape responses in oil risk assessm ent for the Arctic m ay not only give an indication on benthic am pilpods' spatial distribution, which is inversely related to sedim ent toxicity, but also on oil related adverse effects from chronic exposure.

\section{Aim and scope of the thesis}

As described in the foregoing sections there are four $\mathrm{m}$ ain knowledge gaps presently ham pering our ability to $\mathrm{m}$ onitor longterm im pacts of $\mathrm{O} \& \mathrm{G}$ activities on Arctic benthic ecosystem s:

- BSAFs for organic pollutants have been barely reported for Arctic benthic biota, neither evaluated as possible indicators of sedim ent PAH bioavailability.

- Biomarkers of exposure to organic pollution and their responsiveness to sedim ent pollution sources have not been evaluated in Arctic benthos chronically exposed to PAHs.

- Biotransform ation m etabolites of PAHs and their persistence along sedim ent exposure have not been evaluated in Arctic benthos chronically exposed to PAHs.

- Avoidance of DMA-spiked sedim ent and its potential as an oil im pact assessm ent tool have never been studied from the perspective of Arctic benthic biota.

\section{Aim of thesis}

The aim of this thesisis to develop candidate $m$ ethods for the early identification of Arctic bioindicators of $\mathrm{O} \& \mathrm{G}$ and shipping related chem ical stress in Arctic coastabenthic system s. The bioindicator potential of som e Arctic benthicinvertebrate species is evaluated by 


\section{Chapter 1}

specifically m easuring the species traits influence on their PAH uptake and PAH biotransform ation induction during PAH exposure. Species with either sessile or with reduced m obility, different feeding m ode, food selectivity and low dispersal capacity are usedto define a sensitivity range to PAHs and other stressors within our chosen taxa. From that perspective, two of the m ost representative Barents Sea and Chukchi Sea bivalve species, with differing feeding and reproduction traits, the filter feeder Astarte borealis (Schum acher, 1817) and the filter/deposit feeder Macoma calcarea (Gm elin, 1791) were selected as target species in com bination with a predator polychaete,Nephtys ciliata (O.F. Müller, 1776) [112$115]$.

\section{Research questions:}

Q 1:Can PAH body residues or BSAFs be used as bioavailability indicators in Arctic coastal benthic system $\mathrm{s}$ and which target species is $\mathrm{m}$ ost suitable to detect trends?

Q 2: Can species traits explain differences in PAH bioaccum ulationbetween Arctic benthic invertebrates?

Q 3:Does bioaccum ulation of PAHs differ between Arctic and tem perate benthic invertebrate species with different traits, and can m odelling assist in reading across between species?

Q 4: What is the feasibility of using biom akers of exposure to $\mathrm{m}$ onitor PAH pollution in the Arctic? Is the identification of biotransform ation $\mathrm{m}$ etabolites a better alternative?

Q 5:Can behavioural tests like avoidance behaviour becom e a suitable $\mathrm{m}$ onitoring tool for oil im pact assessm ent in the Arcit?

Q 6: What are prospects and advantages of using Arctic benthic bioindicator species for $\mathrm{m}$ onitoring longterm im pacts of $\mathrm{O} \& \mathrm{G}$ and other $\mathrm{m}$ aritim e activities in the Arctic?

The above research questions are answered through a com bination of field and labordory research, and m odelling.

To address $\mathbf{Q} \mathbf{1}$, PAHs, PCBs and HCB body residues were $\mathrm{m}$ easured in the field in $A$. borealis, $M$. calcarea and $N$. ciliata. Differences in body residues am ong two locations in Kongsfjorden ecosystem (Svalbard, Norway), chem icals an species were assessed and BSAF values were obtained. Whether the BSAF $m$ etric is useful as an indicator of PAH availability in Arctic benthic invertebrates under field conditions is investigated in Chapter 2. 


\section{Chapter 1}

To address $\mathbf{Q}$ 2and $\mathbf{Q} 3$ PAH body residues were measured and BSAF values were obtained for the aforem entioned Arctic invertebrates and two Atlantic counterpart species (i.e., Limecola balthica [Linnaeus, 1758] and Alitta virens [Sars, 1835]) under laboratory conditions. PAH bioaccum ulation and bioavailability were com pared between both regional groups and bioaccum ulation was $\mathrm{m}$ odelled in order to $\mathrm{m}$ ake BSAF reading across between groups possible. Results from laboratory experim ents and $\mathrm{m}$ odelling exercises are discussed in Chapter $\mathbf{3}$ and set against field bioaccum ulation conclusions inChapter 2.

To address $\mathbf{Q} \mathbf{4}$ the responsiveness of som e biochem ical biom arkers of exposure, nam ely acyl-CoA oxidase (AOX) and glutathione S-transferase (GST), or acetylcholinesterase (AChE) inhibition in the Arctic bivalve $A$. borealis exposed to a PAH-contam inated sedim ent in laboratory conditions were studied. Additionally, two biotransform ation m etabolites of the m odel PAH pyrene (e.g., 1-hydroxypyrene [OHPyr] and pyrene-1-glucuronide [GluPyr]) were $m$ easured in Arctic (M. calcarea, N. ciliata) and tem perate (L. balthica, A. virens) bivalves and polychaetes exposed to the sam e sedim ent and differing (Arctios tem perate) laboratory conditions. Both groups' PAH biotransformation capacity and estimated chronic toxicity derived from PAH m etabolites bioaccum ulation are discussed inChapter 4.

To address Q $\mathbf{5}$, short-term avoidance by the tem perate freshwater am phipođrammarus pulex (Linnaeus, 1758) and tem perate $\mathrm{m}$ arine benthic am phipođrammarus locusta (Linnaeus, 1758) to DMA-spiked sedim ent was studied and set against results from the available literature in Chapter 5. How and to what extent avoidance $m$ ay affect the longterm perform ance of the am phipods and how the response of the Arctic benthic am phipods $m$ ay differ from their tem perate canterparts are discussed in Chapter 6, based on available literature on oil acute toxicity in Arctic sea-ice and benthic am phipods.

Lastly, m otivated by $\mathbf{Q} \mathbf{6}$ a synthesis is provided in Chapter $\mathbf{6}$ which discusses how physiological and ecological traits $\mathrm{m}$ ay render Arctic coastal benthic species particularly vulnerable to chronic exposure to $O \&$ G related chem icals and how we can identify those at an early stage during $\mathrm{O} \& \mathrm{G}$ production as part of existing biom onitorig program $\mathrm{m}$ es. Incorporating sublethal effects and long-term im pacts of O\& $\mathrm{G}$ waste on Arctic benthic system $\mathrm{s}$ into biom onitoring and risk assessm ent procedures will help to determ ine the odds of oil spill and O\& G im pacts on Arctic m arine ecosystem s and thus, im prove environm ental assessm ent and restorationplanning. 
2 Bioaccumulation of polycyclic aromatic hydrocarbons, polychlorinated biphenyls and hexachlorobenzene by three Arctic benthic species from K ongsfjorden (Svalbard, Norway)

Ariadna S. Szczybelski, Martine J. van den Heuvel-Greve, Tineke Kam pen, Chenwen Wang, Nico W. van den Brink \& Albert A. Koelm ans

Based on:

Szczybelski, A.S., M.J. van den Heuvel-Greve, T. Kam pen, C. Wang, N.W. van den Brink \& A.A. Koelm ans (2016)Bioaccum ulation of polycyclic arom atic hydrocarbons, polychlorinated biphenyls and hexachlorobenzene by three Arctic benthic species from Kongsfjorden (Svalbard, Norway).Marine Pollution Bulletin 112(1-2), 65-74. 


\title{
Chapter 2
}

\begin{abstract}
The predicted expansion of oil and gas $(O \& G)$ activities in the Arctic urges for a better understanding of im pats of these activities in this region. Here we investigated the influence of location, feeding strategy and anim al size on the bioaccum ulation of polycyclic arom atic hydrocarbons (PAHs), polychlorinated biphenyls (PCBs) and hexachlorobenzene (HCB) by three Arctic benthic species in Kongsfjorden (Svalbard, Norway). No toxicity was expected based on biota PAH critical body residues. Biota PCB levels were m ainly below lim it of detection, whereas sam ples were m oderately polluted by HCB. PAH concentrations in bota and biota-sedim ent accum ulation factors (BSAFs) were generally higher in Blom strandhalvøya than in NyÅlesund, which was explained by a higher abundance of black carbon in Ny-Ålesund harbour. BSAFs differed significantly am ong species and stations. We conclude that contam inant body residues are a less variable and $\mathrm{m}$ ore straightforward $\mathrm{m}$ onitoring param eter than sedim ent concentrations or BSAFs in Arctic benthos.
\end{abstract}




\section{Introduction}

The Arctic region is undergoing an unprecedented change, with global rising tem peratures causing an annual sum $\mathrm{m}$ er retreat of sea ice and changes tofor instance, seasonal weather patterns and even ecosystem $\mathrm{s}[116,117]$. The retreat of sea ice will allow expansion of oil and gas $(\mathrm{O} \& \mathrm{G})$ activities in the next decades, posing possible im pacts on the Arctic ecosystem [14]. Besides $O \& G$ activities, changes in clim atic param eters as such $m$ ay affect contam inant transport to and cycling in the Arctic. Furtherm ore, prim ary productivity and food web energetics $\mathrm{m}$ ay be affected and thus the trophic transfer of contam inants. Besides allowing possible expansion of $\mathrm{O} \& \mathrm{G}$ activities, retreat of ice also opens alternative com $\mathrm{m}$ ercia shipping routes, with associated anthropogenic activities and risk of $\mathrm{m}$ aritim e accidents.

It has been claim ed that baseline inform ation on effects of O\& $\mathrm{G}$ activities on the Arctic ecosystem or ecosystem com ponents is still inadequate or unavailablę72]. Further research on linking effects in organism s to exposure to $O \& G$ related contam inants is therefore essential. In this context, identifying chem ical (e.g, petroleum $\mathrm{m}$ arker om pounds like petrogenic PAHs), biological indicators for cum ulative effects of $\mathrm{O} \& \mathrm{G}$ activities that can be applied across the Arctic is highly relevant. Petroleum hydrocarbons are generally considered to be one of the $\mathrm{m}$ ain pollutants related to $\mathrm{O} \& \mathrm{G}$ activilies. Although anthropogenic inputs of PAHs are only a sm all proportion of total hydrocarbon burden in the Arctic environm ent [118], they can create substantial local pollution [119]. Several studies suggest that atm ospheric transport of polycyclic arom atic hydrocarbons (PAHs) has only a m inor influence on sedim entary PAH distributions in the Arctic Ocean[45,120]. However, petrogenic and pyrogenic PAHs have been identified as an em erging concern in the Arctic [121] and there is little inform ation on PAH bioaccum ulation in Arctic benthic species[122]. Since the hydrophobicity of PAHs $m$ ay prom ote their adsorption to settling organic $m$ atter $(\mathrm{OM}), \mathrm{m}$ arine sedim ents and benthic system $\mathrm{s} \mathrm{m}$ ay act first as a sink and ultim ately as a secondary source of PAHs.

Besides PAHs, legacy persistent organic pollutants (POPs) like polychlorinated biphenyls (PCBs), are still ubiquitous in Arctic regions. Local sources are $\mathrm{m}$ ainly found in the form of secondary sources after, for instance, breakdown and decom $\mathrm{m}$ ission of equipm ent and dem olishing of buildings, although long range atm ospheric transport also greatly contributes to the general supply. Contam inants deposited in polar regions typically becom e $\mathrm{m}$ obile during the sum $\mathrm{m}$ er $\mathrm{m}$ onthas glaciers, sea ice and snow $\mathrm{m}$ elting $\mathrm{m}$ ay introduce POPs into the 


\section{Chapter 2}

$m$ arine system $[123,124]$. Input of these contam inants $m$ ay directly im pact the pelagic system when taken up by algae and zooplankton $[125,126]$, and indirectly the benthic com m unities due to a strong pelagic-benthic coupling in the Arctic [127]. PCBs are persistent and hydrophobic organochlorine contam inants with a wide range of biological effects in chronic exposed biota. This $\mathrm{m}$ akes them a suitable chem ical group for environm ental $\mathrm{m}$ onitoring in general.

Hexachlorobenzene (HCB) is another chem ical that is known for its persistence and ability to being transported to the cold polar regions [128]. Potential sources of HCB to the m arine ecosystem m ay com prise b-products and waste such as solid and liquid residues, solid waste, oils and wastewater.

Coal, crude oil and atm ospheric dust have been identified as possible PAH sources in sedim ent sam ples of Svalbard[129]. PAH patterns in sedim ent sam ples showed predom inance of petrogenic PAHs $(20-60 \% \Sigma \mathrm{PAH})$ and Svalbard coal was identified in all sedim ent sam pling stations[129]. Kongsfjorden is a relatively pristine fjord, as direct anthropogenic im pact on the $\mathrm{m}$ arine system at local scales is generally $\mathrm{m}$ uch lower in Svalbard than along the Norwegian coast and in European waters [130]. Strict environm ental policy has resulted in a lim ited contam ination of the Kongsfjorden environm en[1131], although accidental spills or chronic im pacts from local anthropogenic activities still $\mathrm{m}$ ay occur.

Arctic benthic species can be applied as relevant and sensitive bioindicators for the im pact assessm ent of O\& G activities in the Arctic[122,132]. Markert et al. [133] defined a bioindicator as an "organism (or a part of an organism or a community of organisms) that contains information on the quality of the environment (or a part of the environment)". Arctic benthic system s are characterised by a high trophic diversity, relatively long lifespan, and sedentary lifestyles of the species [134]. This $\mathrm{m}$ akes them well suited for studying spatial but also tem poral variability of $O \& G$ related pollution. Om nivore strategies are com $m$ on am ong $\mathrm{m}$ any benthic speciesfrom Arctic shallow benthic com $\mathrm{m}$ unities such as scavenging am phipods[135] $\mathrm{m}$ aking them resilient to changes in seasonal conditions which results in little change in food web structure through the year [136]. Benthic invertebrates are an im portant food sourcefor higher trophic levels in the Arctic such as benthic fishes, bottomfeeding seals (e.g., bearded seals, walruses) and birds (such as the eider duck) [137,138]. The accum ulation and effects of contam inants in benthic species dependson both biological traits 


\section{Chapter 2}

such as diet, habitat preference and longevity [56], and sedim ent characteristics such as grain size and organic carbon content [80]. This results in differences in bioaccum ulation potential am ong benthic invertebrate species, which $\mathrm{m}$ ay be further enhanced by differences in thir biotransform ation capacity of contam inants[139]. Som e inform ation is available on contam inant levels in Arcticbenthic species [140,141], however effects of contam imants in Arctic invertebrates are still poorly understood [142].

The biota-sedim entaccum ulationfactor (BSAF) has been used as a $m$ etric to assess the bioaccum ulation of contam inants in sedim ent and has been com pared across a wide range of aquatic ecosystem s[80-82]. Only a few exam ples of BSAFs for Arctic species are available. BSAFs are reported for PCBs in (sub-)Arctic shorthorn sculpins [84] and for volatile siloxanes in Svalbard Atlantic cods and shorthorn sculpins [85]. We are aware of only one study reporting BSAFs for Arctic benthic invertebrates. PCB BSAFs have been published for Astarte sp. and Nephtys incisa from an Atlantic tem perate region[143].

Aim of the present study was to provide a $m$ ore sysm atic evaluation of bioaccum ulation of PAHs, PCBs and HCB by three Arctic benthic species. This includes assessing differences between species, size classes within species, contam inant groups and sam pling stations. In this study we explore for the first tim e to what extent the BSAF m etric is useful as an indicator for PAH, PCB and $\mathrm{HCB}$ accum ulation in Arctic benthic invertebrate species. The results will be interpreted in light of the usefulness of such $m$ etric for assessm ent of potential im pact of future O\&G activities in the Arctic.

Biota was collected in Kongsfjorden (Svalbard, Norway). Three benthic species (Astarte borealis, Macoma calcarea and Nephtys ciliata) were selected based on their feeding habits, sessility and relative abundance or Valuable Ecosystem Com ponent (VEC) condition (i.e. species that are specifically abundant at ecologically relevant habitats) [144].

Results of this study show the bioaccum ulation potential of PAHs, PCBs and HCB in Arctic benthic species in the field and are used to select the most relevant benthic species and tools for $\mathrm{m}$ onitoring organic contam inants in Arctic sedim ent. 


\section{Chapter 2}

\section{Materials and Methods}

\subsection{Study sites}

Sedim ent was collected in an (stb-)Arctic fjord (Kongsfjorden Bay, Svalbard) and an offshore region (Barents Sea) (Figures 1A-1B). The Svalbard inshore and Barents Sea study areas were located between $71^{\circ}$ and $79^{\circ}$ latitude (Table S3) along which the waters are influenced by the West Spitsbergen Current (WSC). Barents Sea sampling stations depth ranged 110 to $320 \mathrm{~m}$. For a general description of PAH levels in the W Barents Sea the reader is referred to Boitsov et al. [118].

Kongsfjorden ecosystem is a highlatitude (sub-)Arctic fjord $\left(79^{\circ} \mathrm{N}, 12^{\circ} \mathrm{E}\right)$, but the waters are influenced by both the Atlantic water m asses of the WSC as well as the Arctictype coastal waters, and additionally glacial input of $m$ elt water[145]. Depths in the outer basin average 200 to $300 \mathrm{~m}$, whereas the inner basin is considerably shallower (average depth 50-60 m ). Muds dom inate the subtidal sedim ents throughout the fjord. Kongsfjorden inner and outer basins differ with respect to differences in their deposition rates, which are $m$ uch higher in the inner basin, and differences in bioturbatory activity by infaunal organism s distribution[131].

Kongsfjorden shallow benthic $\mathrm{m}$ acrofauna distribution and abundance are influenced by sedim ent characteristics such as grain size, water currents, as well as by different carbon sources such as fresh settling OM, reworked settling OM, m icrophytobenthos and terrestrial OM $[127,136,141,146]$. Two faunal com $m$ unities can $\mathbf{b}$ distinguished in the Kongsfjorden ecosystem according to the frequency of species occurrence, and to several indices of com $m$ unity fidelity of each species in each com m unitfy 47]. The Glacial Bay com m unity (inner basin) is dom inated by sm all m obile bivalves (e.g.Yoldiella solidula) while the Outer Basin com m unity is dom inated by larger, often less $m$ obile, $m$ ostly tubiculous polychaetes (e.g., Pectinaria hyperborea).

\subsection{Collection of field samples}

Sam pling of sedim ent and biota in Kongsfjorden was perform ed at a locally im pacted harbour station (Ny-Ålesund) $[148,149]$ and two reference stations (Blom strandhalvøya and Kapp Guissez) (Figure 1C). Sam pling took place outside the protected areas of Kongsfjorden on board of research vessel MS Teisten (Kings Bay AS, Ny-Ålesund) between 15 and 19 July 2013 and within the Outer Basin com m unity distribution area as defined by Włodarska 


\section{Chapter 2}

Kowalczuk and Pearson [147]. Additionally, sedim ent sam ples were collected at five statios in the West Barents Sea on board of the R/V Lance (Norwegian Polar Institute, Trom sø) between 3 and 10 October 2013 (Table S3). Sedim ent sam ples consisted of soft bottom substrates and were collected using a Van Veen grab $\left(0.1 \mathrm{~m}^{2}\right)$. Biota sam ples were collected at Ny-Ålesund and Blom strandhalvøya using either a Van Veen grab, or a sm all dredge. Three Arctic $m$ arine benthic invertebrate species with different feeding behaviours were collected: A. borealis (Schum acher, 1817) (m ollusc; suspension feeder), M. calcarea (Gm elin, 1791) (m ollusc; deposit and suspension feeder), andN. ciliata (O.F. Müller, 1776) (polychaete; om nivore). Sedim ent sam ples were preserved in $250 \mathrm{~m}$-glass jars at $-20{ }^{\circ} \mathrm{C}$ until analysis. The organism s were allowed to depurate for $24 \mathrm{~h}$ in dean sea water from the fjord before dissection. Anim als were weighed, m easured, dissected andpooled by size class (Table S2). Size classes were defined such that each class had sufficient num bers of individuals to allow statistical testing. The soft tissue of bivalves was rem oved from the shell and sam ples were pooled in groups of 5 to 12 individuals before freezing at- $20{ }^{\circ} \mathrm{C}$. Sedim ent and biota sam ples were all shipped frozen in dry-ice to Wageningen University (Wageningen, the Netherlands) for chem icalanalysis.

\subsection{Chemical analysis}

Chem ical analysis was described before[150]. The following PAHs and POPs were analysed: Phenanthrene (PHE), Anthracene (ANT), Fluoranthene (FLT), Pyrene (PYR), Benz(a)anthracene (BaA), Chrysene (CHR), Benzo(e)pyrene (BeP), Benzo(b)fluoranthene $(\mathrm{BbF})$, Benzo(k)fluoranthene (BkF), Benzo(a)pyrene (BaP), Indeno(1,2,3-cd)pyrene (Ind123P), Dibenz( $a, h)$ anthracene (dBahA), Benzo(ghi)perylene (BghiP), hexachlorobenzene (HCB), PCB-18, -20, -28, -29, -31, -44, -52, -101, -105, -118, -138, -153, -170, -180, -194, 204 and -209 .

For details on extraction, clean-up and instrum ental analysis see the Supporting Inform ation (SI). In short: sedim entand biota sam ples were Soxhletextracted with hexane/acetone.

Extracts were cleaned over $\mathrm{Al}_{2} \mathrm{O}_{3}(\mathrm{PAH})$, or $\mathrm{Al}_{2} \mathrm{O}_{3} /$ silica (HCB and PCBs) and analysed using HPLC-UV and GC-ECD, respectively. Recoveries were 53 to 77\% (PAHs in biota), 66 to $79 \%$ (HCB and PCBs in biota), 57 to 67\% (PAHs in sedim ent) and 79 to $103 \%$ (HCB and PCBs in sedim ent). Besides recoveries, num erous blanks were used. All data wee corrected for the resulting values. 


\section{Chapter 2}

Subsam ples of each sedim ent sam ple were analysed for weight perentages (wt. \%) of OM content, $\mathrm{m}$ easured as loss on ignition $\left(550^{\circ} \mathrm{C}, 3 \mathrm{~h}\right)$. Biota lipids were extracted with chloroform :m ethanol:water and quantified graim etrically.

\subsection{Data analyses}

Lipid-norm alised biota concentrations were calculated. BSAFs were calculated as $\left(\mathrm{C}_{\text {org }} / f_{\text {lip }}\right) /\left(\mathrm{C}_{\text {sed }} / \mathrm{f}_{\text {SOM }}\right)$ with $\mathrm{C}_{\text {org }}$ being the chem ical concentrationin the organism in wet weight (wet wt.; $\mu \mathrm{g} / \mathrm{kg}$ ), $\mathrm{C}_{\text {sed }}$ the chem ical concentration in sedim ent in dry weight (dry wt.; $\mu \mathrm{g} / \mathrm{kg}$ ), $\mathrm{f}_{\text {lip }}$ the fraction of lipids in the organism based on wetwt., and $\mathrm{f}_{\mathrm{SOM}}$ the fraction of sedim ent organic m atter (SOM) based on dry wt. BSAFs of a specific com pound were calculated provided that there were at least three detects (i.e., >LOD) for the sam e com pound in sedim ent sam ples. Only those com pounds for which $\geq 90 \%$ BSAF values were above zero in both stations were included in the statistical analysis. Data were checked for norm ality with Q-Q plots and Shapiro-Wilk test and equality of variances with Levene's test. Lipidnorm alised biota concentrations and BSAFs were tested for location and size effect with the Mann-Whitney $U$ test and Kruskal-Wallis test, respectively for each PAH and PCB com pound as well asfor HCB and the sum of PAHs $\left(\Sigma_{13} \mathrm{PAH}\right)$ and $7 \mathrm{PCBs}\left(\Sigma_{7} \mathrm{PCB}\right)$. Significance level of an overall statistical com parison was set at $p \leq 0.05$, while for pairwise com parisons a Bonferroni correction was applied. All statistical calculations were perform ed using SPSS version 22.

PAH diagnostic ratios were applied to assess em ission sources of PAHs in sedim ent. Sources can be pyrogenic (originated from com bustion), petrogenic (originated from oil) or a com bination of these. It has been shown that PAH isom ers with $\mathrm{m}$ asse202 (e.g., FLT, PYR) and 276 (e.g., BghiP, Ind123P) have the greatest range in stability of PAHs, thus they are good indicators of petroleum $v s$ com bustion sources[120,151]. PAH ratios FLT/(FLT+PYR) and Ind123P/(Ind123P+BghiP) were calculated. A FLT/(FLT+PYR) ratio of $<0.4,0.4-0.5$ and $>0.5$ points out to petrogenic sources, fuel com bustion or grass/wood/coal com bustion, respectively. A Ind123P/(Ind123P+BghiP) ratio of $<0.5$ or $>0.5$ points out to fuel com bustion or grass/wood/coal com bustion, respectively. However, this relationship is not universal and interpretation of this m easure should only be used indicatively.

Sedim ent (based on drywt.) and biota (based on lipid wt.) PAH and PCB concentrations were evaluated based on Environm ental Quality Standards (EQSs) established by the Norwegian 
Environm ent Agency[152], Environm ental Assessm ent Criteria (EACs) established by the OSPAR Com m ission[153] and Critical Body Residues (CBRs) established by the USEPA [154].

Concentrations below the EACs are considered to present no significant risk to the environm ent, and to that extent $\mathrm{m}$ ay be considered as being related to the EQSs applied to concentrations of contam inants inwater [155]. CBRs established by the USEPA are based on the target lipid m odel suggested by Di Toro et al.[156].

\section{Results and Discussion}

\subsection{Concentrations of PAH s, PCBs and H CB in sediment}

PAHs in sediment. For Kongsfjorden sam ples, concentrations of $\Sigma_{13} \mathrm{PAH}$ varied between 12 and $2315 \mu \mathrm{g} / \mathrm{kg}$ dry wt. (geom etric m ean 139 $\mathrm{g} / \mathrm{kg}$ dry wt.), whereas for Barents Sea sam ples, this range was between 39 and $4270 \mu \mathrm{g} / \mathrm{kg}$ dry wt. (geom etric m ean $823 \mu \mathrm{g} / \mathrm{kg}$ dry wt.) (Table S4). Ny-Ålesund sedim ents were contam inated quid uniform ly with $\Sigma_{13} \mathrm{PAH}$ concentrations ranging from 1815 to $2315 \mu \mathrm{g} / \mathrm{kg}$ dry wt. (geom etric m ean $2011 \mu \mathrm{g} / \mathrm{kg}$ dry wt.). Towards the northern fjord shelf (Blom strandhalvøya) and the inlet from Kongsfjorden to Krossfjorden (Kapp Guissez), PAH levels decreased. In the Barents Sea, significant differences were found for PHE and BeP am ong distant stations (e.g., SE Edgeøyavs Snøhvit, Figures 1A-1B). This $\mathrm{m}$ ay indicate differences in deposition, the presence of local sources such as natural seepages of oil or other organic fossils, or differences in SOM content. No significant differences were found am ong stations relatively close to each other (e.g., SE Edgeøya S2-S4) or am ong distant stations located within the NW Barents Sea study area (e.g., E Kong Karls Land vs SE Edgeøya).

Sediment PAH diagnostic ratios. Based on PAH ratios, sedim ent PAHs seem ed to originate from com bustion of grass, wood, coal or petroleum (Barents Sea, N-ẙlesund), from com bustion of grass, wood and coal (Kapp Guissez), and from com bustion of rgss, wood and coal or from petroleum (Blom strandhalvøya) (Table 1). In N-ẙlesund sedim ents, uncom busted coal also is relevant. After all, PAHs from coal are ubiquitous in the Svalbard environm ent where extensive coal m ining was carried out by Kings Bayni Ny-Ålesund until 1962 [157]. In a study of surface sedim ent collected between the Barents and Kara Sea shelves, the highest pyrogenic PAH levels (sum of 4 to 6-ring hydrocarbons, perylene 


\section{Chapter 2}

excluded) were found in sedim ents from Kola, the Pechenga Bays and Svalbard inshore [129]. Highest pyrogenic PAH levels in Barents Sea and Kongsfjorden were reached in sedim ents from station 2 (SE Edgeøya) and 8 (Kapp Guissez) (Table 1).

Table 1. Sedim ent parent PAH diagnostic ratios.

\begin{tabular}{|c|c|c|c|c|c|c|c|c|c|}
\hline & & \multicolumn{5}{|c|}{$\begin{array}{c}\text { Barents Sea } \\
\text { (October 2013) }\end{array}$} & \multicolumn{3}{|c|}{$\begin{array}{c}\text { Kongsfjorden } \\
\text { (July 2013) }\end{array}$} \\
\hline \multicolumn{2}{|l|}{ PAH ratio } & S1 & S2 & $\mathrm{S} 3$ & S4 & S5 & S6 & S7 & S8 \\
\hline \multirow{2}{*}{$\mathrm{FLT} /(\mathrm{FLT}+\mathrm{PYR})$} & Min & $\begin{array}{l}0.43 \\
\text { (B) }\end{array}$ & $\begin{array}{l}0.53 \\
(\mathrm{C})\end{array}$ & $\begin{array}{l}0.45 \\
\text { (B) }\end{array}$ & $\begin{array}{l}0.44 \\
\text { (B) }\end{array}$ & $\begin{array}{l}0.00 \\
\text { (A) }\end{array}$ & $\begin{array}{l}0.63 \\
(\mathrm{C})\end{array}$ & $\begin{array}{l}0.31 \\
\text { (A) }\end{array}$ & $\begin{array}{l}0.48 \\
\text { (B) }\end{array}$ \\
\hline & Max & $\begin{array}{r}0.47 \\
\text { (B) }\end{array}$ & $\begin{array}{r}0.57 \\
(\mathrm{C})\end{array}$ & $\begin{array}{l}0.48 \\
\text { (B) }\end{array}$ & $\begin{array}{l}0.49 \\
(\mathrm{~B})\end{array}$ & $\begin{array}{l}0.52 \\
\text { (C) }\end{array}$ & $\begin{array}{l}0.65 \\
\text { (C) }\end{array}$ & $\begin{array}{l}0.35 \\
\text { (A) }\end{array}$ & $\begin{array}{l}0.55 \\
\text { (C) }\end{array}$ \\
\hline \multirow{2}{*}{ Ind123P/(Ind123P+BghiP $)$} & Min & $\begin{array}{l}0.80 \\
(\mathrm{C})\end{array}$ & $\begin{array}{l}0.82 \\
\text { (C) }\end{array}$ & $\begin{array}{l}0.77 \\
(\mathrm{C})\end{array}$ & $\begin{array}{l}0.79 \\
(\mathrm{C})\end{array}$ & $\begin{array}{l}0.81 \\
(\mathrm{C})\end{array}$ & $\begin{array}{l}0.34 \\
\text { (B) }\end{array}$ & $\begin{array}{l}0.21 \\
\text { (B) }\end{array}$ & $\begin{array}{l}0.83 \\
(\mathrm{C})\end{array}$ \\
\hline & Max & $\begin{array}{l}0.83 \\
\text { (C) }\end{array}$ & $\begin{array}{l}0.85 \\
\text { (C) }\end{array}$ & $\begin{array}{l}0.79 \\
\text { (C) }\end{array}$ & $\begin{array}{l}0.80 \\
\text { (C) }\end{array}$ & $\begin{array}{l}0.87 \\
(\mathrm{C})\end{array}$ & $\begin{array}{l}0.43 \\
\text { (B) }\end{array}$ & $\begin{array}{l}0.79 \\
\text { (C) }\end{array}$ & $\begin{array}{l}0.86 \\
\text { (C) }\end{array}$ \\
\hline
\end{tabular}

(A) Petrogenic sources; (B) Fuel com bustion sources; (C) Grass/wood/coal com bustion sources.

Sediment Quality Assessment based on PAH concentrations. Effect Range (ER) values were established as sedim ent quality guidelines to be used to predict adverse biological effects on $m$ arine organism \$158]. ERL (ER lower tenth percentile) values are available for 9 individual PAHs (PHE, ANT, FLT, PYR, BaA, CHR, BaP, Ind123P and BghiP) below which adverse effects on organism s are rarely observed. An ERL in sedim ent for the sm of PAHs (2990 $\mu \mathrm{g} / \mathrm{kg}$ dry wt.) was calculated as the sum of the 9 PAH ERLs. The geom etric $\mathrm{m}$ eans of the sum of 9 PAHs in sedim ent sam ples from our study (Barents Sea and Kongsfjorden, respectively) were 32 to 39 tim es lower than the 9 PAH ERL. However, in alm ost all Barent Sea (S2-S4) and all Ny-Ålesund (S6) sam ples PHE concentrations were above its individual ERL value (i.e., $240 \mu \mathrm{g} / \mathrm{kg}$ dry wt.). Additionally, FLT, BbF, dBahA and Ind123P concentrations in som e Barents Sea sam ples (stations S3-S4, Figure 1A) were within the interval of acute effects for short term exposure (Class IV) established by the Norwegian Environm ent Agency[152]. In som e cases (station S4), PYR concentrations were even within the interval of severe toxic effects ( $>140 \mu \mathrm{g} / \mathrm{kg}$ dry wt., Class V) established by this sam e institution. 

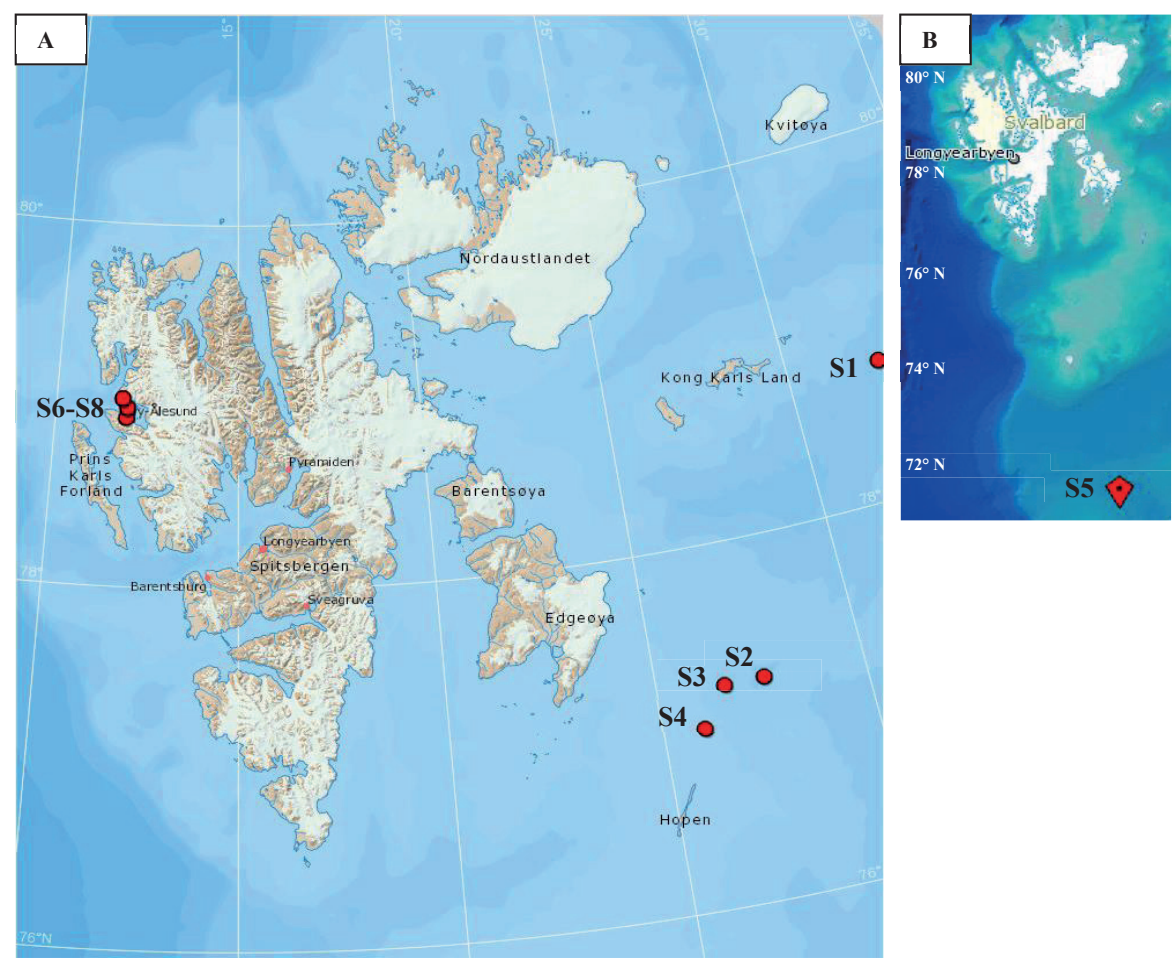

Figure 1. A: Barents Sea (S1-S4) and Kongsfjorden (S6-S8) sam pling stations (Basem ap (C) Norwegian Polar Institute). B: Snøhvit sam pling station (S5) (MAREANO m apping (C) Institute of Marine Research).

PCBs in sediment. For Kongsfjorden sam ples, $\Sigma_{7} \mathrm{PCB}$ concentrations varied between 0.00002 and $0.13 \mu \mathrm{g} / \mathrm{kg}$ dry wt. (geom etric m ean $0.001 \mu \mathrm{g} / \mathrm{kg}$ dry wt.), whereas for Barents Sea sam ples this range was between below lim it of detection and $0.04 \mu \mathrm{g} / \mathrm{kg}$ dry wt. (geom etric $\mathrm{m}$ ean below lim it of detection) (Table S5)Highest concentrations of $\Sigma_{7} \mathrm{PCB}$ were detected in Ny-Ålesund sedim ents where concentrations varied between 0.002 and $0.13 \mu \mathrm{g} / \mathrm{kg}$ dry wt. (geom etric m ean $0.01 \mu \mathrm{g} / \mathrm{kg}$ dry wt.). Significant differences were found between $\mathrm{Ny}$ Ålesund and Blom strandhalvøya station for PCB-18, -105, -118, -138 and -155 (MannWhitney $U$ test, $p<0.05$ ). PCB concentrations in Kongsfjorden sedim ent were within the range of earlier reported PCB concentrations in Kongsfjorden sedim ent[149]. In other Svalbard fjords, $\Sigma_{7} \mathrm{PCB}$ sedim ent concentrations of 0.74 to $5.41 \mu \mathrm{g} / \mathrm{kg}$ dry wt. in Barentsburg (Grønfjorden) and 1.8 to $20.2 \mu \mathrm{g} / \mathrm{kg}$ dry wt. in Pyram iden (Billefjorden) were reported in 2008, showing 6 to 14 orders of m agnitude higher concentrations than in $\mathrm{Ny}$ - $\AA$ lesund sam ples included in our study $[159,160]$. PCB-138 and PCB- $153 \mathrm{~m}$ ade up $60 \%$ of $\Sigma_{7} \mathrm{PCB}$ in som e $\mathrm{Ny}$ 


\section{Chapter 2}

Ålesund sedim ent sam ples and 53\% o $£_{7} \mathrm{PCB}$ in Barentsburg sedim ent sam ples in 2008[159] which $m$ ay point to different local sources[140,161,162].

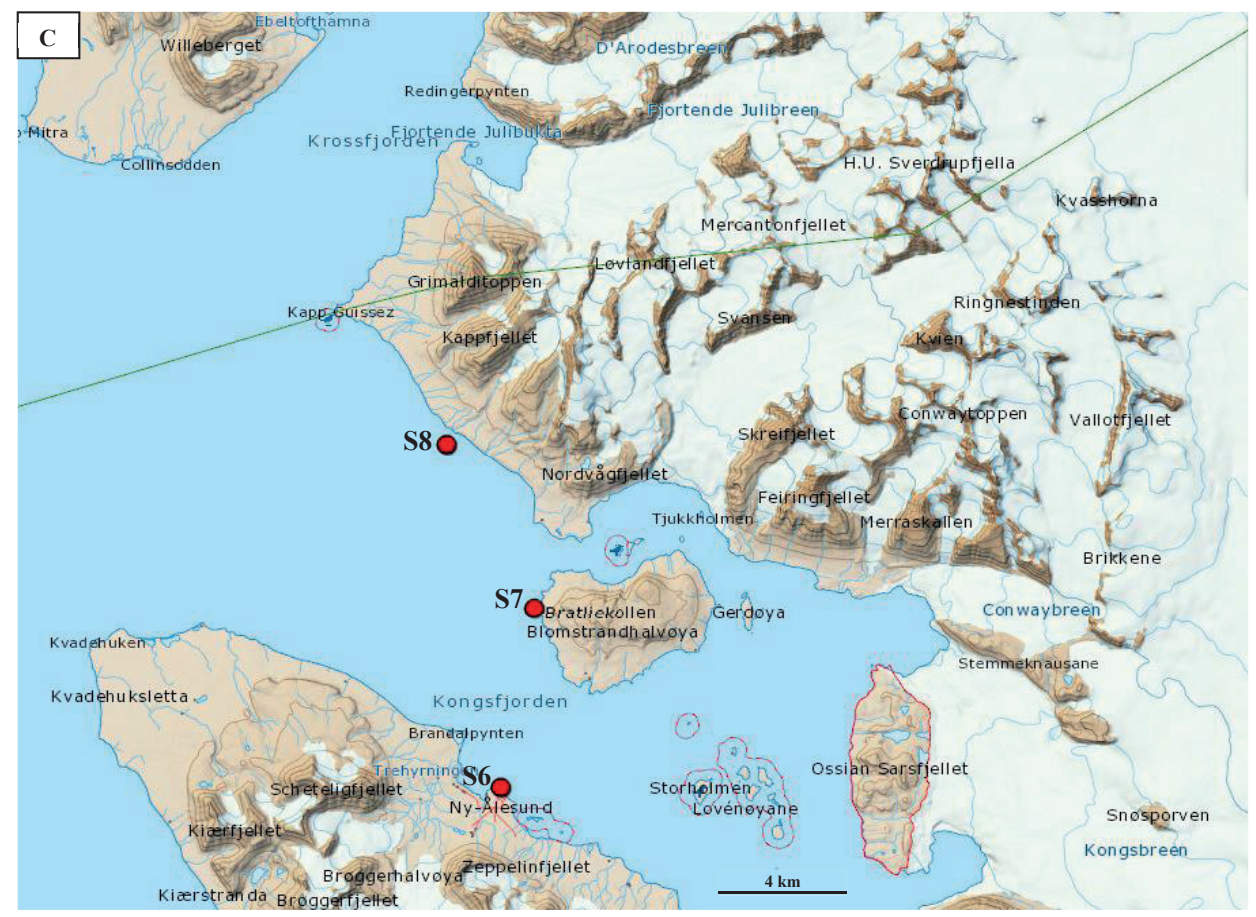

Figure 1. C: Kongsfjorden sam pling stations (S6-S8). From north to south: Kapp Guissez (S8), Blom strandhalvøya (S7) and Ny-Ålesund (S6) harbour (Basem ap C Norwegian Polar Institute).

HCB in sediment. HCB concentrations in Kongsfjorden sam ples were between below lim it of detection and $0.01 \mu \mathrm{g} / \mathrm{kg}$ dry wt., whereas concentrations of the Barents Sea sedim ent sam ples varied between below lim it of detection and $0.37 \mu \mathrm{g} / \mathrm{kg}$ dry wt. (Table S5). For Kongsfjorden and Barents Sea sam ples, significant differences were found between $\mathrm{Ny}$-Ålesund and Blom strandhalvøya station (Kruskal-Wallis test, $p=0.037$ ) as well as between SE Edgeøya (S3) sedim ents whereHCB concentrations ranged 0.17 to $0.37 \mu \mathrm{g} / \mathrm{kg}$ dry wt. and Snøhvit (S5) sedim ents where HCB concentrations were $\leq 0.00003 \mu \mathrm{g} / \mathrm{kg}$ dry wt. (Kruskal-Wallis test, $p=$ 0.037). 


\subsection{Sediment organic matter content}

For Kongsfjorden, SOM percentages varied between 3.7\% in Kapp Guissez and 6.3\% in NyÅlesund, and for the Barents Sea sam ples between $4.9 \%$ in E Kong Karls Land and $9.1 \%$ in SE Edgeøya (S2) (Table S4).

\subsection{Concentrations of PAH s, PCBs and $\mathrm{H} \mathrm{CB}$ in biota}

\subsubsection{Polycyclic aromatic hydrocarbons}

PAH concentrations in biota. Am ong species and stations, $\Sigma_{13} \mathrm{PAH}$ concentrations in benthic invertebrates of Kongsfjorden varied between 27 and $9185 \mu \mathrm{g} / \mathrm{kg}$ lipid wt. (geom etric m ean $729 \mu \mathrm{g} / \mathrm{kg}$ lipid wt.) (Table S9). Lowest $\Sigma_{13} \mathrm{PAH}$ concentrations were found in A. borealis at the Ny-Ålesund sam pling station, whereas highest $\Sigma_{13}$ PAH concentrations were observed in N. ciliata sam ples at Blom strandhalvøya (Figre 2). In general the highest concentrations in A. borealis and N. ciliata were found in Blom strandhalvøya sam ples, whereas concentrations in M. calcarea sam ples didnot differ m uch between stations. In our study,A. borealis specim ens ( $\mathrm{Ny}$ Ålesund) were $\mathrm{m}$ ainly exposed to both petroleum and coal com bustion derived PAH sources in the field based on the agreem ent between m ean PAH ratios (FLT/[FLT+PYR] and Ind123P/[Ind123P+BghiP]) calculated for both $\mathrm{Ny}-\AA$ Alesund bivalves $(0.49 / 0.52)$ and sedim ent $(0.64 / 0.38)$ sam ples[ 163,164$]$. 


\section{Chapter 2}

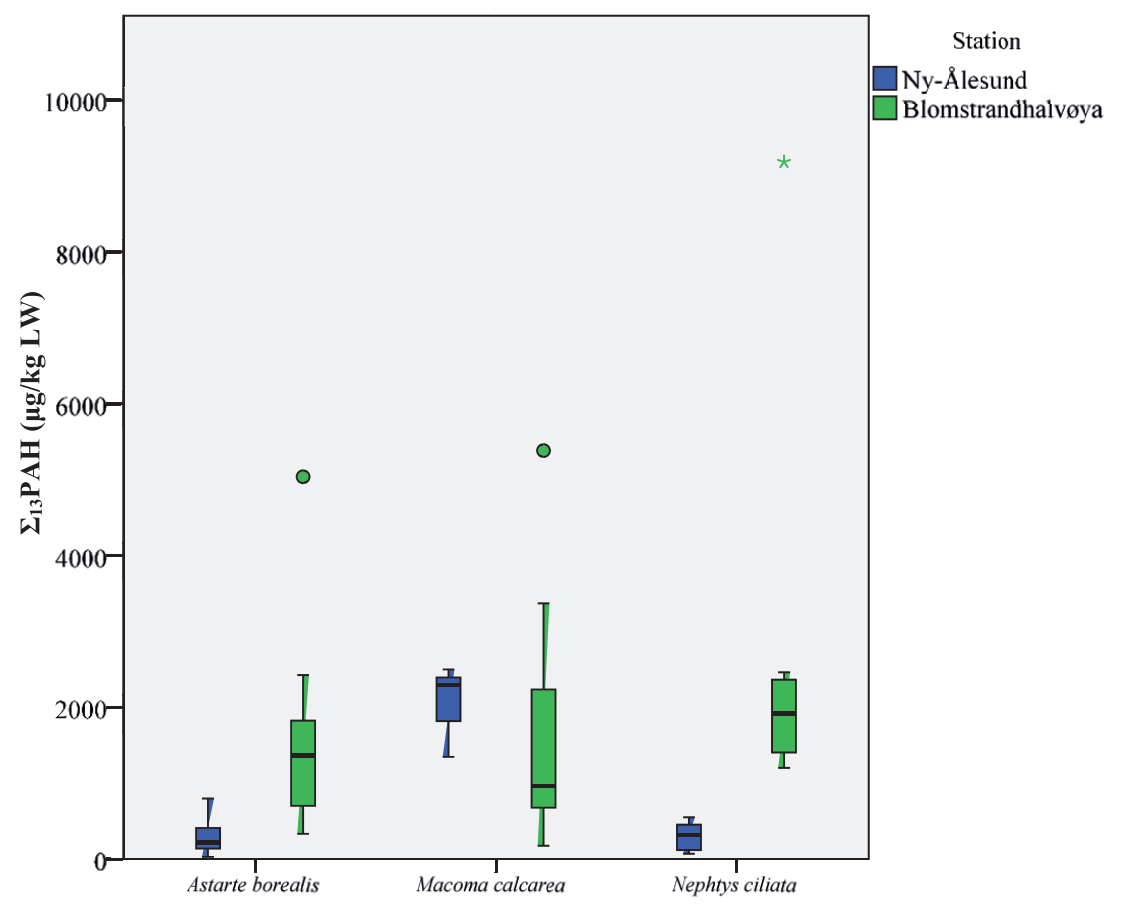

Figure 2. $\Sigma_{13} \mathrm{PAH}$ concentrations ( $\mu \mathrm{g} / \mathrm{kg}$ lipid wt.) in benthic invertebrates of Kongsfjorden.

PAH Critical Body Residues. To assess potential effects resulting from PAH bioaccum ulation, the $m$ easured concentrations can be com pared to USEPA CBR levels. Hansen et al[154] calculated a $\Sigma_{13} \mathrm{PAH}$ total lipid LC50 body burden ( $96 \mathrm{~h}$ ) for $N$. arenaceodentata (polychaeta) and for L. stagnalis (gastropoda) as 280,000 and 330,000 $\mu \mathrm{g} / \mathrm{g}$ lipid wt. (using a $\Sigma_{13} \mathrm{PAH} \mathrm{W}_{\mathrm{m}}$ $(\mathrm{m}$ olar weight $)=3058 \mu \mathrm{g} / \mu \mathrm{m} \mathrm{ol})$. This is a factor of 30,500 to $65,500 \mathrm{tim}$ es higher than the $\mathrm{m}$ ean $\Sigma_{13}$ PAH lipid-norm alisedconcentrations found in any of our species

(Blom strandhalvøya).

Hwang et al. [165] found a CBR of $\Sigma_{24} \mathrm{PAH}$ for lysosom al destabilization (at least $50 \%$ of destabilized cells) of $2100 \mu \mathrm{g} / \mathrm{kg}$ dry wt. in eastern oysters (C. virginica). Assum ing a $20 \%$ and $12 \%$ dry wt. (based on soft tissue wet wt.) in A. borealis [166] and in M. calcarea [167], respectively, the m axim $u \Sigma_{13} \mathrm{PAH}$ values detected in Blom strandhalvøya $A$. borealis and $M$. calcarea specim ens are 3 to 8 tim es lower (258 and $620 \mu \mathrm{g} / \mathrm{kgdry}$ wt., respectively) than the $\Sigma_{24} \mathrm{PAH}$ CBR calculated by Hwang et al. [165]. 
Based on EACs for PAHs established in m ussels and oysters[153], and assum ing 20\%dry wt. in A. borealis, $\mathrm{m}$ ean concentrations of PHE, FLT and PYR inA. borealis Blom strandhaløya specim ens were 22, 6 and 2 tim es lower than the corresponding EAC.

Liu et al. [168] observed the induction of aryl hydrocarbon hydroxylase (AHH) and 7ethoxyresorufin O-deethylase (EROD) enzym atic activities in $R$. philippinarum individuals with internal $\mathrm{BaP}$ concentrations of approxim ately $2.02 \mu \mathrm{g} / \mathrm{g}$ dry wt. in the digestive gland. Assum ing 20\% and 12\%dry wt. (based on soft tissue wet wt.) in A. borealis and M. calcarea, respectively, and accepting that a great proportion of $\mathrm{BaP}$ should be accum ulated in the digestive gland of bivalves $[169,170]$, then the $\mathrm{m}$ axim um $\mathrm{BaP}$ concentrations detected ind. borealis (Blom strandhalvøya) andM. calcarea (Ny-Ålesund) would be 108 to 465 tim es lower ( 0.02 and $0.004 \mu \mathrm{g} / \mathrm{g}$ dry wt., respectively) than the sam e concentration doserved by Liu et al. [168].

In sum $\mathrm{m}$ ary, no potential toxicity o $£_{13} \mathrm{PAH}$ to A. borealis, M. calcarea or $N$. ciliata Blom strandhalvøya populations was indicated according to hree CBRs m entioned. Biotransform ation enzym atic activity $\mathrm{m}$ ight be also negligible in the case of bivalves, according to the results obtained by Liu et al. [168] for R. philippinarum.

Differences in PAH concentrations among stations. Several factors were identified that can explain differences in PAH bioaccum ulation between $\mathrm{Ny}$-Ålesund (NY) and Blom strandhalvøya (BL). A sum $\mathrm{m}$ ary of factors in relation to ecological processes is provided as Figure 3, and in the discussion below we refer to these factors and processes as NY- $x$ and BL- $y$, where $x$ and $y$ correspond to the num bers as indicated in Figure 3. Nearly all lipid-norm alisedindividual PAH concentrations in the polychaete $N$. ciliata were significantly higher in Blom strandhalvøya than inNy-Ålesund specim ens (Table S6). The lower $\Sigma_{13} \mathrm{PAH}$ content in Ny-Ålesund specim ens (Table $\$$ ) can be explained by different factors. The $\mathrm{m}$ ost im portant factor $\mathrm{m}$ ay be differences in bioavailabilityrelated to differences in OM quality between sites. For instance, sedim ent in $\mathrm{Ny}$ Ålesund harbour contained clearly visible black carbon (BC) particles that are known to strongly bind organic contam inants such as PAHs $\mathrm{m}$ aking them less available for uptake[78] (Figure 3, factor NY-7). BC particles ( $\geq 10 \mu \mathrm{m}$ ) predom inate in surface sedim ents from the $\mathrm{m}$ iddle part of the Kongsfjorden com pared to the outer part [171]. $\mathrm{BC} \geq 10 \mu \mathrm{m}$ are usually associated with local sources such as fossitfuel fired power stations located in different Svalbard hum an settlem ents. Secondly, transport of coal particles from form er coal $\mathrm{m}$ ines within the Bayelva river catchm ent area, west of $\mathrm{Ny}$ 


\section{Chapter 2}

Ålesund, $\mathrm{m}$ ight also influence the final bioavailability of sedim entbased PAH sources, particularly in Ny-Ålesund A. borealis and N. ciliata specim ens[148,172]. Thirdly, ongoing degradation of weathered oil in Ny-Ålesund $[148,172]$ could have a highly significant im pact on Ny-Ålesund individuals (Figure 3, factor NY-6) as this would m inim ize their in depth and deposit feeding in the weathered oil im m ediately surrounding area.

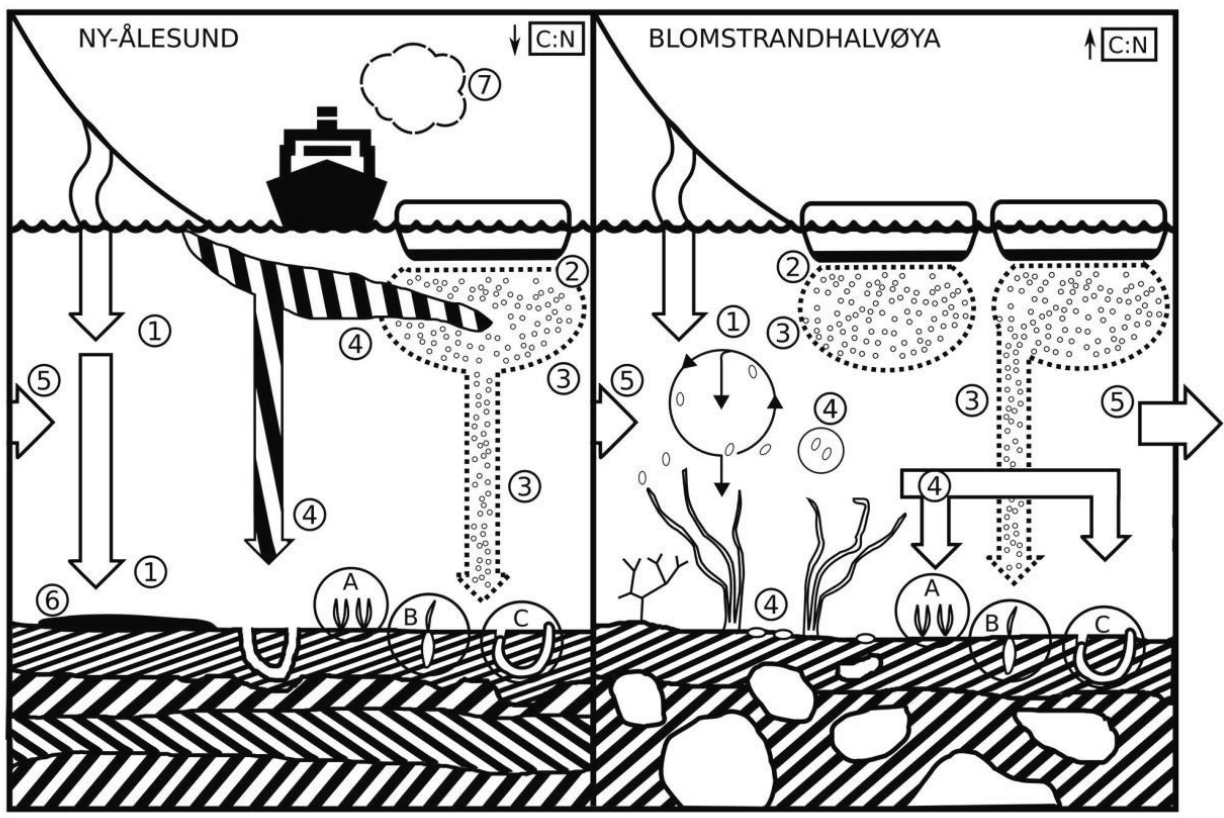

Figure 3. Possible factors contributing to observed differences between sam pling stations. Ny-Ålesund (NY): (1) terrestrial particulate organic m atter (POM), (2) ice algae, (3) fresh pelagic/settling organic $\mathrm{m}$ atter $(\mathrm{OM})$, (4) clayish river runoff, (5) advected and reworked detritus, (6) weathered oil, (7) volatile organic com pounds (VOCs).Blomstrandhalvøya (BL): (1) terrestrial POM, (2) ice algae, (3) pelagic/settling OM, (4) brown m acroalgal $\mathrm{m}$ aterial, (5) advected and reworked detritus. A:Astarte borealis, B: Macoma calcarea, C: Nephtys ciliata.

Additionally, differences in OM quality related to differences in species and biom ass com position ofphytoplankton bloom $\mathrm{s}$ and in $\mathrm{m}$ acroalgae biom ass would partly explain different benthic PAH bioaccum ulation patterns between stations. A higher predom inance of ice diatom s (Figure 3, factor BL-2) prom oted by the resuspension of nutrients as a direct consequence of the continuous down-fjord advection of deep freshwater [145] (Figure 3, factor BL-5), as well as a higher input of m acroalgal detritus[173] (Figure 3, factor BL-4), 


\section{Chapter 2}

are expected to increase the PAHs partitioning from the water phase $\mathbf{b}$ fresh settling OM (Figure 3, factor BL-3) as both algal $\mathrm{m}$ aterials are rich in polyunsaturated fatty acids (PUFAs) [174]. A higher relative intake of PUFA-rich $m$ aterialm ay increase the bioavailability of PAHs in Blom strandhalvøya, particularly in the case of filter feeders (e.g, A. borealis). Finally, stream s leaving Blom strandhalvøya carried a m uch higdr terrestrial settling OM (Figure 3, factor BL-1) concentration per both water volum e and dry wt of suspended $\mathrm{m}$ atter than the Bayelva river (Ny-Ålesund) [146] (Figure 3, factor NY-1). A higher input of terrestrial $\mathrm{OM}$ in Blom strandhalvøya can contribute to the $\mathrm{m}$ ineralization of settling $\mathrm{OM}$ during sedim entation which evertually would increase the OC-norm alisedpartition coefficients in settling particles [175-177].

A short response tim e to fresh settling OM m ay also increase PAH bioaccum ulation iM. calcarea as concentrations of ANT, $\mathrm{BaA}, \mathrm{BaP}$ and $\mathrm{dBahA}$ in $M$. calcarea $\mathrm{Ny}-\AA ̊$ lesund specim ens were significantly higher than in Blom strandhalvøya specim ens. Bayelva river outflow usually contains a high proportion of clay m aterials (Figure3, factor NY-4) that could also enhance phytoplankton $\mathrm{m}$ ortality while zooplankton $\mathrm{m}$ ay suffer from direct $\mathrm{m}$ ortality[131]. The im $\mathrm{m}$ ediate decrease of phytoplankton grazing by zooplankton due to the oxygen depletion of surface waters, would ultim ately favour the sedim entation $\delta \mathrm{m}$ ore fresh phytoplankton (Figure 3, factors NY-2 and NY-3), which M. calcarea basically feeds on and to which PAHs $\mathrm{m}$ ay adsorb.M. calcarea is also one of the few benthic species in the Kongsfjorden of which a low trophic level and $\delta^{13} \mathrm{C}$ m ay suggest that this species is $\mathrm{m}$ ainly reliant on fresh phytoplankton or fresh phytodetritus during sum m er[136,178]. Additionally, a lower PAH excretion capacity in $M$. calcarea $[179,180]$ com pared to the other two species $\mathrm{m}$ ay contributeto the observed differences between Ny-Ålesund and Blom strandhalvøya $M$. calcarea individuals.

In sum $\mathrm{m}$ ary, lipienorm alised PAH concentrations in all species seem ed to be affected by som e station related variation. This $\mathrm{m}$ ay be explained by either a differece in SOM content, origin and sedim entation rate of settling $\mathrm{OM}$ and $\mathrm{BC}$ strength source between stations.

Differences in PAH concentrations among species. BaP, dBahA and Ind123P burden in $N$. ciliata was significantly higher than in both bivalve species at Blom strandhalvøya (Table S7). This $\mathrm{m}$ ay be caused by a $\mathrm{m}$ ore opportunistic feeding pattern ofN. ciliata when com pared to the bivalve species. Regarding Ny-Ålesund sam ples, nearly all lipidnorm alisedindividual PAHs concentrations were significantly higher in $M$. calcarea com pared with the other two 


\section{Chapter 2}

species (Table S7). Since steady-state PAH body burdens in polychaetes can also be greatly influenced by biotransform ation processes[139,181], chronic PAH exposure is suggested to increase the inducibility of PAH biotransform ation enzym es (e.g.CYP) in Ny-Ålesund polychaetes, and thus the probability of finding lower PAH body burdens in Ny-Ålesund individuals [182]. Additionally, specific CYP enzym es involved in xenobiotic biotransform ation often are induced by substrates upon which they act, so that the $\mathrm{m}$ ere presence of som e PAHs m ay trigger the expression of CYP enzym es (e.g.PYR and PYR hydroxylase) [183]. However, long-term PAH detoxification $\mathrm{m}$ ight be slower, if not negligible as explained in the PAH critical body residues section, in bivalves since the $\mathrm{m}$ ajor site of uptake and accum ulation in these organism $\mathrm{s}$ is the digestive gland [169] whereas CYP genes transcription has been described as a tissue specific process reflecting the im portance of gills in PAH detoxification [184].

In general, ingestion of SOM has been described as the $\mathrm{m}$ ajor uptake pahway of organic contam inants in tem perate benthic species (1. virens, L. balthica) [56]. Additionally, a higher ingestion rate, $\mathrm{m}$ ore pportunistic diet and higher derm al exposure of $N$. ciliata could lead to an extended bioaccum ulation of sedim entbound PAHs [185]. A. borealis (filter-feeder) and M. calcarea (deposit-feeder) feed m ainly on fresh phytoplankton or fresh phytodetritus, as shown by an abundance in algal-derived fatty acids in the sam e species[186,187]. In a Chukchi Sea study perform ed by Neff et al.[188], इPAH (parent and alkylated com pounds) concentrations were also higher in Macoma sp. clam s and m aldanid worm s than indstarte sp. This $\mathrm{m}$ ay be due to the fact that, as a deposit-feeder, M. calcarea $\mathrm{m}$ ay also actively ingest SOM.

In general, differences in species-specific PAH accum ulation patterns were seen between the three species, which can be explained by differences in uptake and elim ination rates between these species due to underlying $\mathrm{m}$ echanism $\mathrm{s}$ that however could not be assessed unam biguously from the data.

Differences in PAH concentrations among species size-classes. For the Kruskal-Wallis test, a Bonferroni correction was applied and all effects are reported at a 0.0167 level of significance. We conclude that there is no significant size-class effect on A. borealis lipidnorm alised PAHconcentrations (Table S10), neither on M. calcarea (Blom strandhalvøya) PAH concentrations. Sim ilarly, no significant differences were found in $\Sigma_{13} \mathrm{PAH}$ lipidnorm alised concentrations between both bivalves sizeclasses. 


\subsubsection{Polychlorinated biphenyls}

Concentrations of PCBs in biota were below lim it of detection in $\geq 90 \%$ of the biota sam ples analysed for every species and from both $\mathrm{Ny}$ Ålesund and Blom strandhalvøya station. PCBs were therefore excluded from further analyses.

\subsubsection{H exachlorobenzene}

Am ong species and stations, concentrations of $\mathrm{HCB}$ varied between $<0.01$ and $14.16 \mu \mathrm{g} / \mathrm{kg}$ lipid wt. The $\mathrm{m}$ inim um and $\mathrm{m}$ axim um values were detectedAnborealis ( $\mathrm{Ny}$-Ålesund) and M. calcarea (Blom strandhalvøya), respectively. In general the highest concentrations in biota tissues were found in Blom strandhalvøya specim ens M. calcarea Blom strandhalvøya individuals were assessed as m arkedly polluted (Class Ito Class III for HCB, between 0.1 and $1 \mu \mathrm{g} / \mathrm{kg}$ wet wt.) according to the EQSs for blue m ussels defined by the Norwegian Environm ent Agency[189]. HCB lipid-norm alisedconcentrations were found to be significantly higher in A. borealis (Mann-Whitney $U$ test, $p<0.001$ ) and M. calcarea (MannWhitney $U$ test, $p=0.005$ ) Blom strandhalvøya specim ens than in their NyÅlesund counterparts. An interspecies com parison within Blom strandhalvøya station sam ples showed significantly higher (Kruskal-Wallis test, $p=0.027$ ) HCB lipid-norm alisedconcentrations in A. borealis specim ens. No size effect on HCB lipidnorm alisedconcentrations was reported after applying a Bonferroni correction.

\subsection{Biota-sediment accumulation factors}

For organism $\mathrm{s}$ that are closely linked to the sedim ent and are exposed $\mathrm{m}$ ainly to sedim ent bound contam inants, the BSAF has been shown to be a useful $m$ etric of boaccum ulation $[56,82]$. Here we explore to what extent BSAF is useful to assess bioaccum ulation in the Arctic species studied, hypothesizing that BSAF has the lowest value for suspension feeder $A$. borealis. Data were sufficient to calculate BSAF values only for PAHs. Mean BSAF values are presented in Tables S11, S13 and S15 for both stations.

For Blom strandhalvøya, the 1090th percentile range of $\Sigma_{13}$ PAH BSAF values per species was 0.59 to 3.50 for A. borealis, 0.35 to 4.76 for M. calcarea and 1.88 to 5.50 for N. ciliata, which thus shows a som ewhat higher accum ulation than the value of BSAF $=12$ as predicted by Equilibrium Partitioning Theory (EPT) for hydrophobic contam inants[190]. Sim ilar BSAF values have been reported earlier in the literature [56,83,191-193]. One explanation is 


\section{Chapter 2}

that EPT neglects the ingestion pathway, whereas this pathway is relevant in nature. Another potential explanation is that uptake was not from the sedim ent com partm ent but $m$ erely from freshly deposited or settling suspended solids and their am bient water[136,194], having higher chem ical concentrations than the sam pled sedim entdue to atm ospheric or m eltwater based sources of PAHs $[121,177,195]$. In Ny-Ålesund, the 10-90th percentile range of $\Sigma_{13}$ PAH BSAF values per species was 0.00 to 0.02 for $A$. borealis, 0.05 to 0.07 for $M$. calcarea and 0.00 to 0.02 for $N$. ciliata. These general ranges of the $\Sigma_{13} \mathrm{PAH}$ BSAF values in Ny-Ålesund com ply very well with the BSAF values found for BC im pacted sites[196,197]. Sedim ents in Ny-Ålesund contain BC [171,198]. This is consistent with inform ation from the m ean PAH diagnostic ratios FLT/(FLT + PYR) and Ind123P/(Ind123P + BghiP), which were $>0.5$ and $0.2-0.5$, respectively (Table 1 ), and reflect a pyrogenic origin of these chem icals [120].

PAH BSAF values were significantly higher in Blom strandhalvøya specim ens com pared to Ny-Ålesund specim ens (Tables S12, S14 and S16). In the case of A. borealis, all considered BSAFs were significantly higher (Mann-Whitney $U$ test, $p<0.001$, Table S12) in Blom strandhalvøya specim ens. As forM. calcarea and N. ciliata Blom strandhalvøya sam ples, significant differences between the stations were found in FLT, PYR, BaA, CHR and BghiP (Mann-Whitney $U$ test, $p<0.05$, Table S14) BSAFs and FLT, BaA, CHR, BbF, BghiP and Ind123P (Mann-Whitney $U$ test, $p<0.05$, Table S16) BSAFs in the first and second species, respectively.

An interspecies com parison within Blom strandhalvøya station sam ples showed significantly higher BbF BSAFs in A. borealis (Kruskal-Wallis test, $p=0.006$ ) whereas the sam e com parison within $\mathrm{Ny}-\AA$ Alesund showed significantly higher FLT, BaA and CHR BSAFs in M. calcarea (Kruskal-Wallis test, $p<0.05$ ). No size class effect was observed in either of the species PAH BSAFs.

\section{Implications and Conclusions}

Our data analysis provides the first system atic evaluation of BSAF patterns across chem icals, locations and species in the Arctic. PAH concentrations and BSAFs were higher in Blom strandhalvøya specim ens which was explainedby stronger sorption to $\mathrm{BC}$ and lesser uptake from ingested sedim ent in NyÅlesund which in turn im plies that the use of the BSAF concept is not straightforward in these ecosystem s. We conclude that PAH body residues can 
be applied as a less variable and $m$ ore straightforward pollution $m$ onitoring param eter than sedim ent concentrations or BSAFs as biota body concentrations in low trophic level species give a good estim ate of the bioavailable fraction of organic contam inants present in the system . Based on thisfield study, the filter/deposit-feeding bivalve $M$. calcarea is proposed as a (sub-)Arctic indicator of O\& G-derived environm ental im pacts due taits ability to accum ulate PAHs in low O\& G im pacted areas (e.g.Ny-Ålesund) regardless of its body size class and to its selective feeding m ode which decreases uncertainty on the species bioavailable PAH sources.

\section{Acknowledgements}

Axel Meldahl (captain of the Teisten research vessel of Kings Bay AS [Ny-Ålesund, Svalbard] in sum m er 2013), Ben Frederiks (sam pling asstance), Anja Johansen Haugerud (Equinor ASA, logistics assistance), Anita Evenset, Oddm und J. Isaksen andKristine Hopland (Akvaplan-niva AS, logistics assistance) are highly thanked for their contributions. Diego Rivera is kindly thanked for his contribution on Figure 3 drawing. Equinor ASA and the Wageningen UR TripleP@Sea innovation program m e (The Netherlands) are acknowledged for funding the ARCIND project. 


\section{Chapter 2}

\section{Supporting Information}

\section{Extraction, clean-up and instrumental analysis}

Frozen sedim ent sam ples(Barents Sea) and freeze-dried sedim ent sam ples (Kongsfjorden) were thawed at room tem perature. Frozen pooled biota sam ples were thawed at room tem perature and subdivided into replicates of equal weight before drying. Sedim ent subsam ples and biota replicats were dried and grinded with diatom aceous earth and Soxhlet extracted for $40 \mathrm{~m}$ in with hexane/acetone (3:1) (DionexASE 350 System, Therm o Scientific). All extracts were split in two. One part was cleaned-up over an $\mathrm{Al}_{2} \mathrm{O}_{3}$ colum $\mathrm{n}$ and used for PAH analysis, which was carried out on an HP 1100 HPLC equipped with a $4.6 \mathrm{~m} \mathrm{~m}$ Vydac guard and analytical reverse phase C18 colum n (201GD54T and 201TP54, respectively) which were kept at $22.00{ }^{\circ} \mathrm{C}$. Detection was perform ed by an HP $1100 \mathrm{~m}$ ultiwavelength fluorescence detector operating in the $\mathrm{m}$ ultiem ission wavelength $\mathrm{m}$ ode. The $\mathrm{m}$ obile phase consisted of $\mathrm{m}$ ethanol/water ( $\mathrm{m}$ ixture and flow gradient). The injection volum e was $20 \mu \mathrm{L}$.

The other part was cleaned-up using an $\mathrm{Al}_{2} \mathrm{O}_{3}$ /silica colum n, desulfurized with Cutpowder, and used for PCB and HCB analysis. PCBs were m easured by splitless injection of $1 \mu \mathrm{L}$ of sam ple in an upgraded HP 5890 series II gas chrom atograph equipped with an HP 7673A autosam pler system, two fused silica capillary colum ns, CP Si8 CB and CP Sil-5 CB (both 50 m.; i.d. $0.15 \mathrm{~m} \mathrm{~m}$; d.f. $0.20 \mu \mathrm{m})$, and tw $8^{3} \mathrm{Ni}$ electron capture detectors. The injector and detector tem peratures were 250 and $325^{\circ} \mathrm{C}$, respectively. Carrier gas was $\mathrm{N}(1 \mathrm{~m} \mathrm{~L} / \mathrm{m}$ in $)$.

Besides recoveries 3 blanks per each batch of 30 sam ples were used, and values were corrected for blanks. 
Chapter 2

Table S1. HCB and PCBs lim it of detection (LOD, $\mu \mathrm{g} / \mathrm{L}$ ) and lim it of quantification (LOQ, $\mu \mathrm{g} / \mathrm{L}$ ).

\begin{tabular}{lll} 
Com pound & LOD & LOQ \\
\hline HCB & 0.08 & 0.27 \\
\hline PCB 18 & 0.25 & 0.85 \\
\hline PCB 20 & 0.13 & 0.43 \\
\hline PCB 28 & 0.13 & 0.42 \\
\hline PCB 29 & 0.47 & 1.58 \\
\hline PCB 31 & 0.11 & 0.37 \\
\hline PCB 44 & 0.34 & 1.14 \\
\hline PCB 52 & 0.76 & 2.53 \\
\hline PCB 101 & 0.12 & 0.40 \\
\hline PCB 105 & 0.09 & 0.30 \\
\hline PCB 118 & 0.09 & 0.32 \\
\hline PCB 138 & 0.08 & 0.28 \\
\hline PCB 153 & 0.13 & 0.42 \\
\hline PCB 155 & 0.09 & 0.29 \\
\hline PCB 170 & 0.08 & 0.28 \\
\hline PCB 180 & 0.07 & 0.23 \\
\hline PCB 194 & 0.08 & 0.27 \\
\hline PCB 204 & 0.03 & 0.09 \\
\hline PCB 209 & 0.10 & 0.32 \\
\hline
\end{tabular}

Table S2. Biota sam ples size classification.

\begin{tabular}{|c|c|c|c|c|}
\hline Species & $\begin{array}{l}\text { Size } \\
\text { class }\end{array}$ & $\begin{array}{l}\text { Shell/body length } \\
(\mathrm{m} \mathrm{m})\end{array}$ & $\begin{array}{c}\text { Blom strandhalvøya } \\
\text { specim ens }\end{array}$ & $\begin{array}{c}\text { Ny-Ålesund } \\
\text { specim ens }\end{array}$ \\
\hline \multirow{4}{*}{ Astarte borealis } & 1 & $\leq 35.9$ & 39 & \\
\hline & 2 & $36.0-37.9$ & 20 & \\
\hline & 3 & $38.0-39.9$ & 15 & 25 \\
\hline & 4 & $\geq 40.0$ & 12 & 45 \\
\hline \multirow{3}{*}{$\begin{array}{l}\text { Macoma } \\
\text { calcarea }\end{array}$} & 1 & $\leq 25.5$ & 30 & \\
\hline & 2 & $25.6-26.5$ & 15 & 10 \\
\hline & 3 & $\geq 26.6$ & 30 & \\
\hline \multirow{4}{*}{ Nephtys ciliata } & 1 & $\leq 84.9$ & 20 & \\
\hline & 2 & $85.0-93.9$ & 25 & \\
\hline & 3 & $94.0-102.9$ & & 10 \\
\hline & 4 & $\geq 103.0$ & & 15 \\
\hline
\end{tabular}




\section{Chapter 2}

Table S3. Sam pling stationsin Barents Sea and Kongsfjorden Bay (Svalbard, Norway).

\begin{tabular}{|c|c|c|c|c|c|c|}
\hline Location & Station & Latitude & Longitude & $\begin{array}{c}\text { Water } \\
\text { depth } \\
(\mathrm{m})\end{array}$ & $\begin{array}{l}\text { Sedim ent } \\
\text { sam ples } \\
\left(0.1 \mathrm{~m}^{2}\right)\end{array}$ & Biota spp. \\
\hline E Kong Karls Land & S1 & $78^{\circ} 45.8^{\prime}$ & $32^{\circ} 53.6^{\prime}$ & 250 & 4 & n.a. \\
\hline SE Edgeøya & S2 & $77^{\circ} 14.0^{\prime}$ & $27^{\circ} 37.0^{\prime}$ & 230 & 3 & n.a. \\
\hline SE Edgeøya & S3 & $77^{\circ} 13.8^{\prime}$ & $26^{\circ} 39.6^{\prime}$ & 130 & 3 & n.a. \\
\hline SE Edgeøya & S4 & $77^{\circ} 00.0^{\prime}$ & $26^{\circ} 00.0^{\prime}$ & 110 & 3 & n.a. \\
\hline Snøhvit & S5 & $71^{\circ} 37.1^{\prime}$ & $21^{\circ} 04.3^{\prime}$ & 320 & 5 & n.a. \\
\hline Ny-Ålesund & S6 & $78^{\circ} 55.0^{\prime}$ & n.a. & $15-20$ & 4 & $\begin{array}{c}\text { Astarte borealis, } \\
\text { Macoma calcarea, } \\
\text { Nephtys ciliata }\end{array}$ \\
\hline Blom strandhalvøya & S7 & $78^{\circ} 59.0^{\prime}$ & n.a. & $20-25$ & 4 & $\begin{array}{c}\text { Astarte borealis, } \\
\text { Macoma calcarea, } \\
\text { Nephtys ciliata }\end{array}$ \\
\hline Kapp Guissez & S8 & $79^{\circ} 02.0^{\prime}$ & n.a. & $45-50$ & 4 & $\begin{array}{c}\text { Astarte borealis, } \\
\text { Nephtys ciliata }\end{array}$ \\
\hline
\end{tabular}




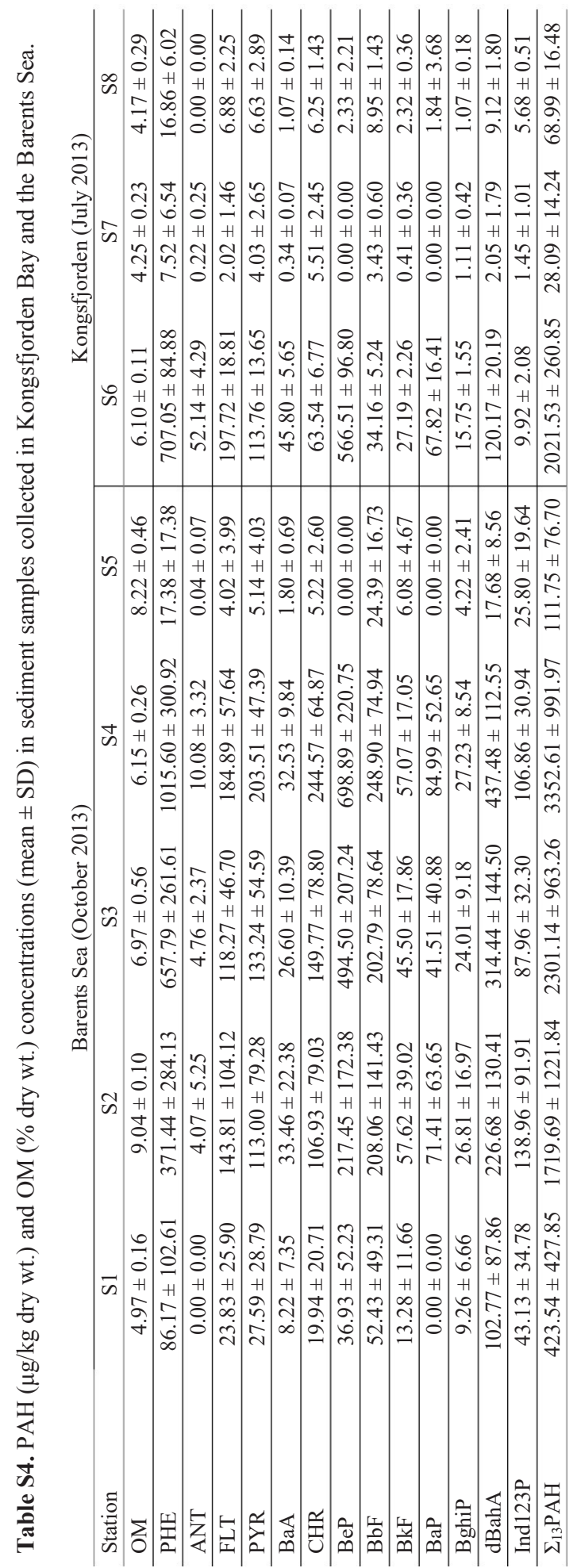


Chapter 2

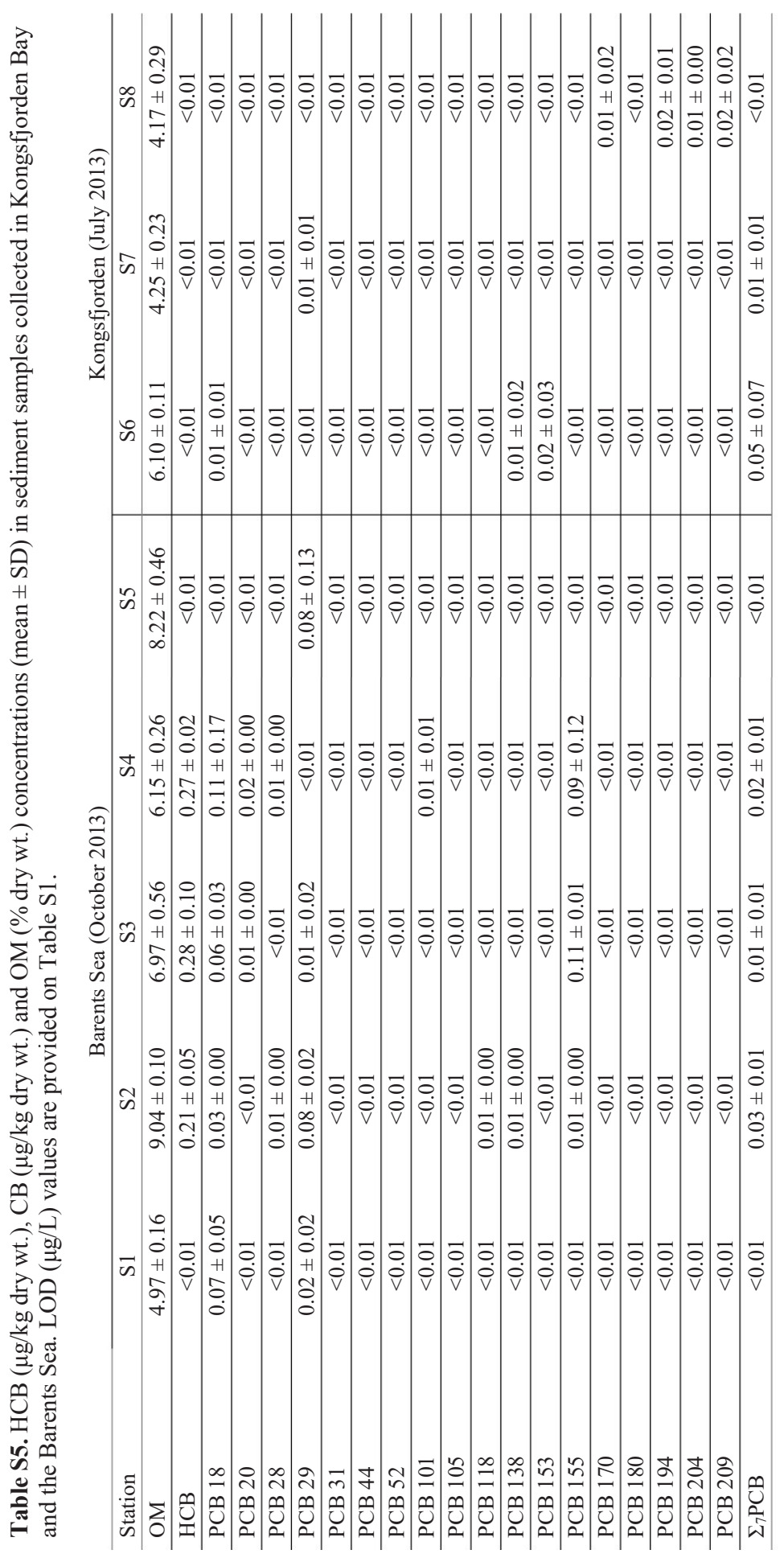

50

Ariadna Szczybelski Thesis Headers.indd 50

26-09-18 09:23:01 
Chapter 2

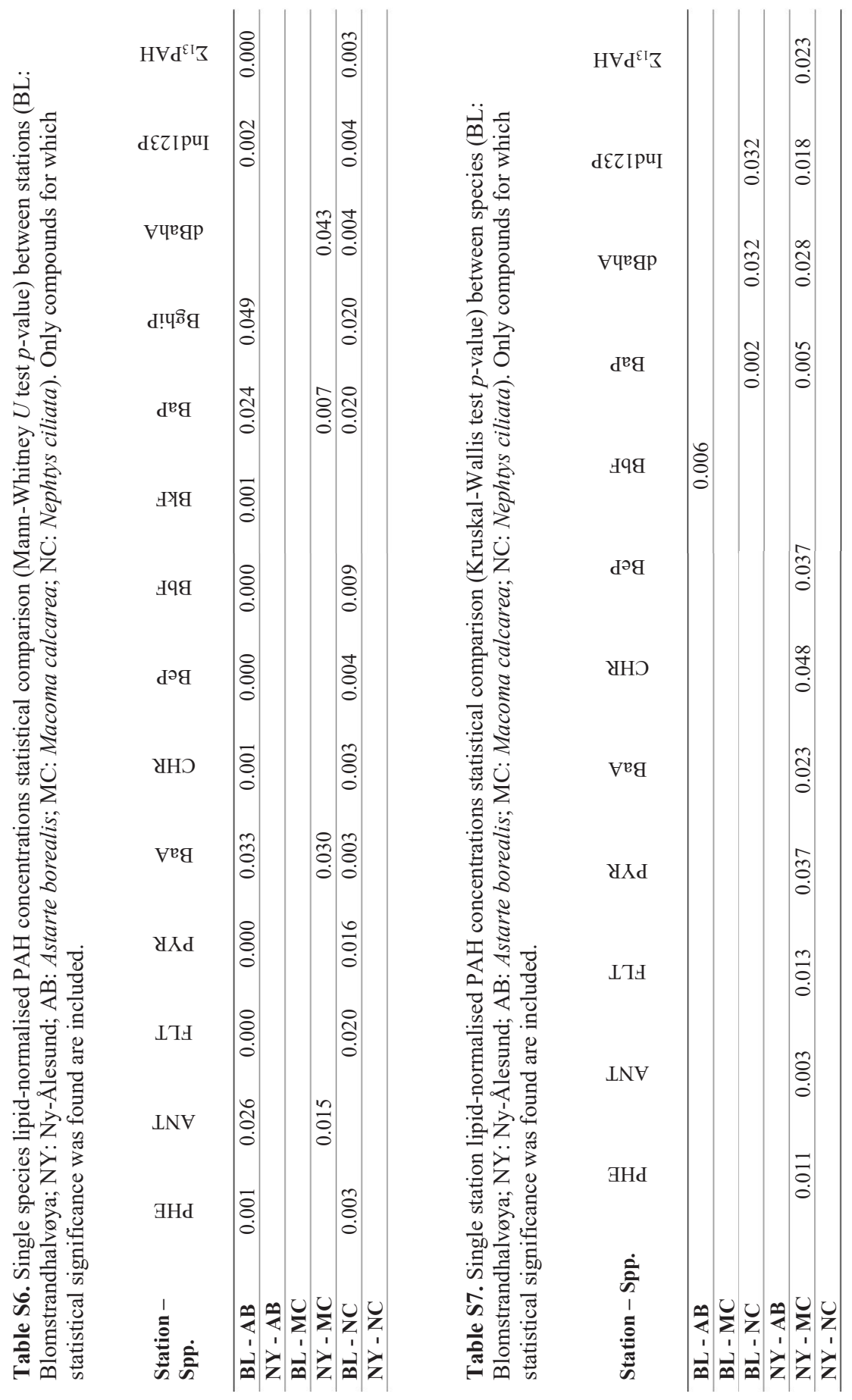

$\oplus$ 


\section{Chapter 2}

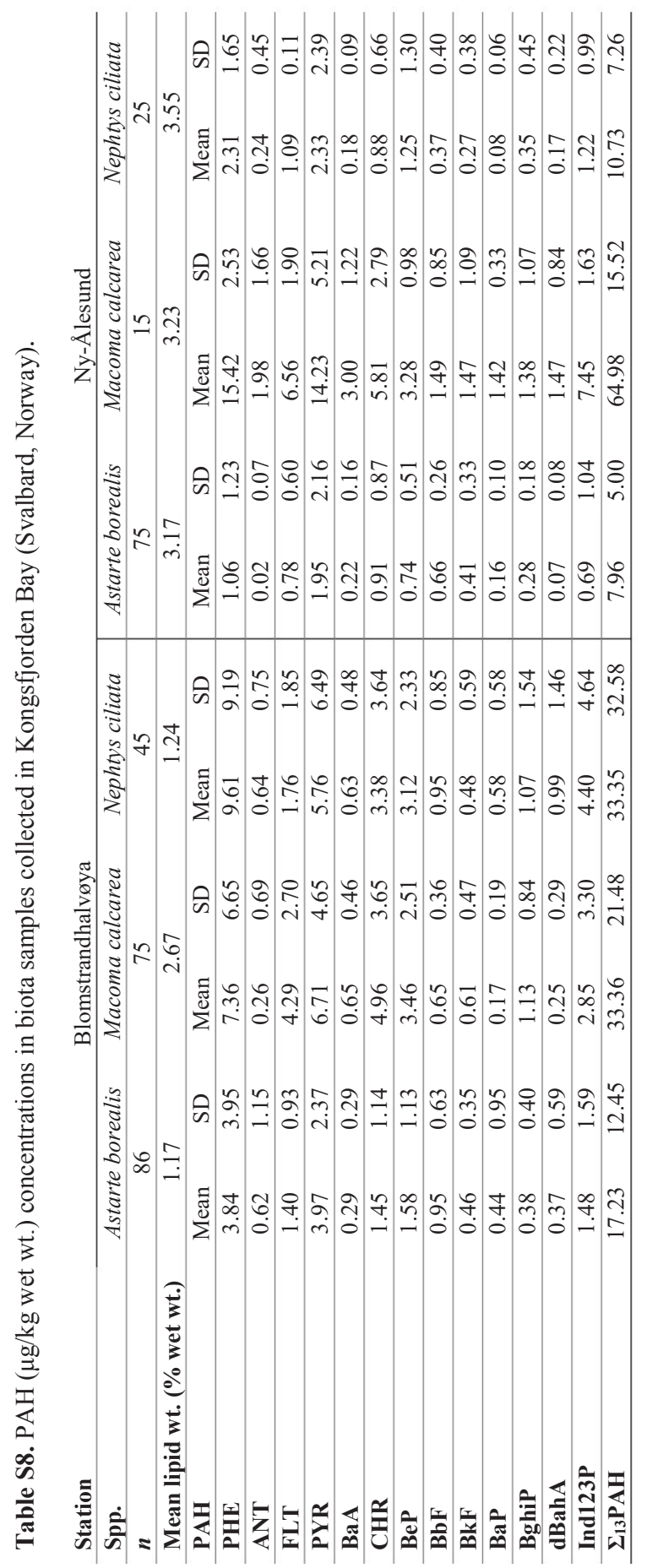




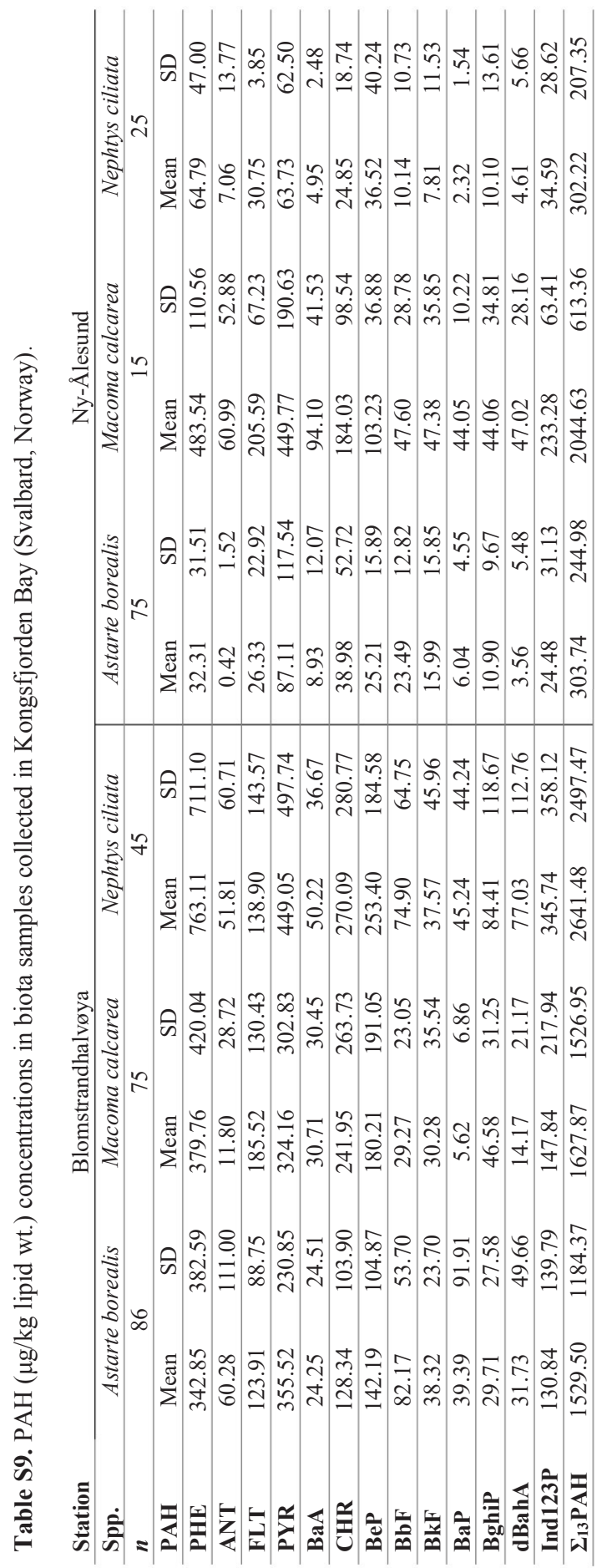




\section{Chapter 2}

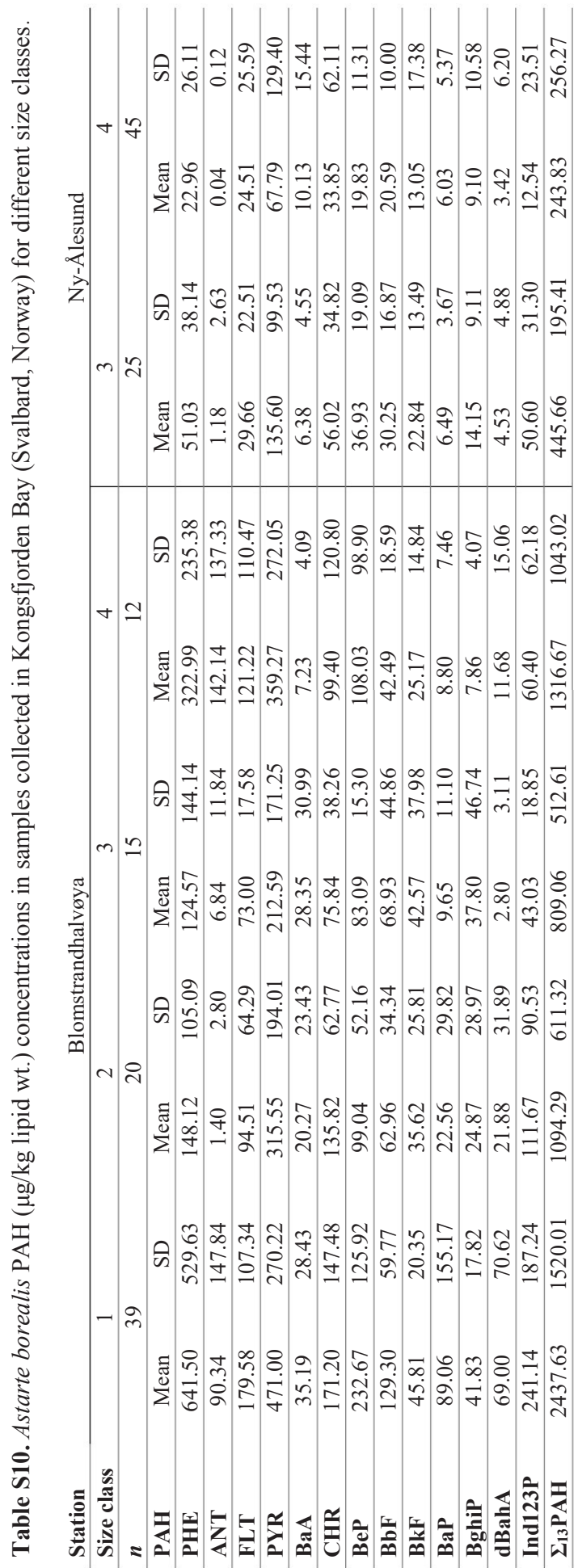




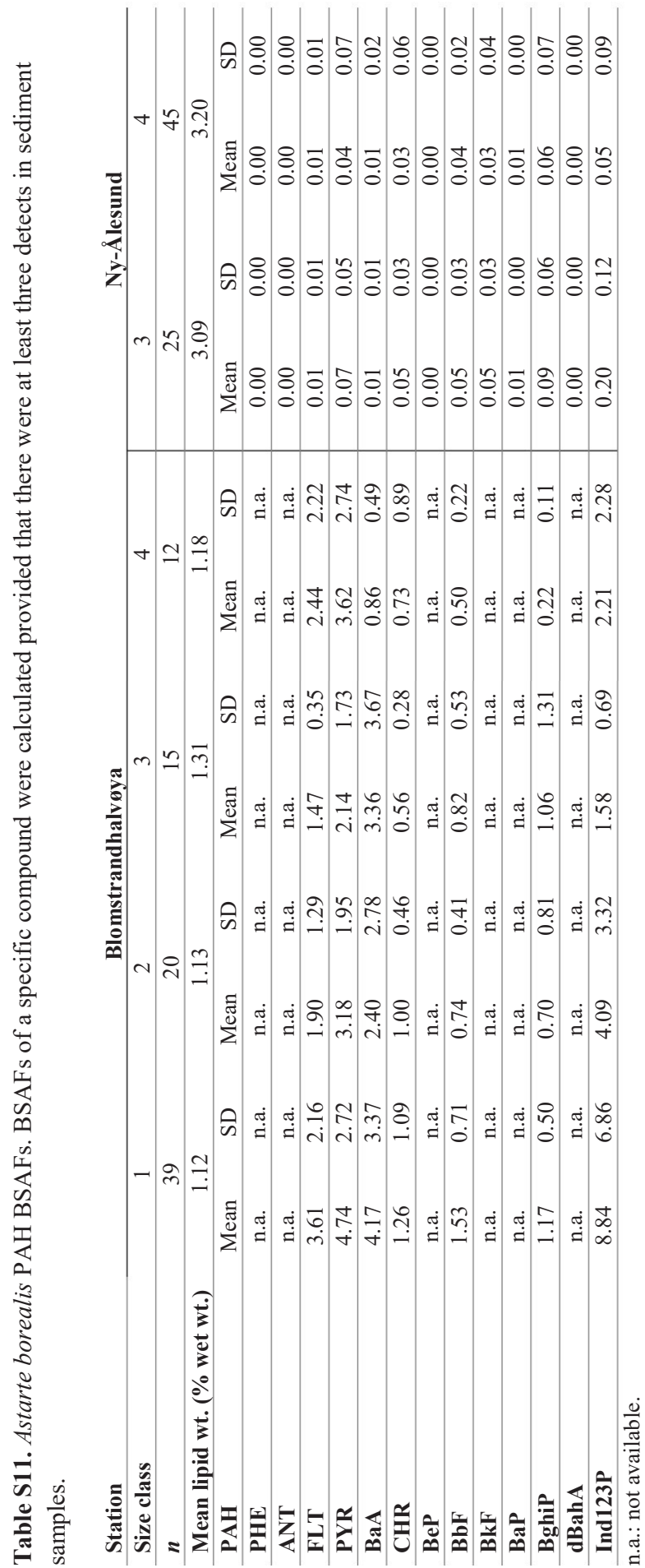




\section{Chapter 2}

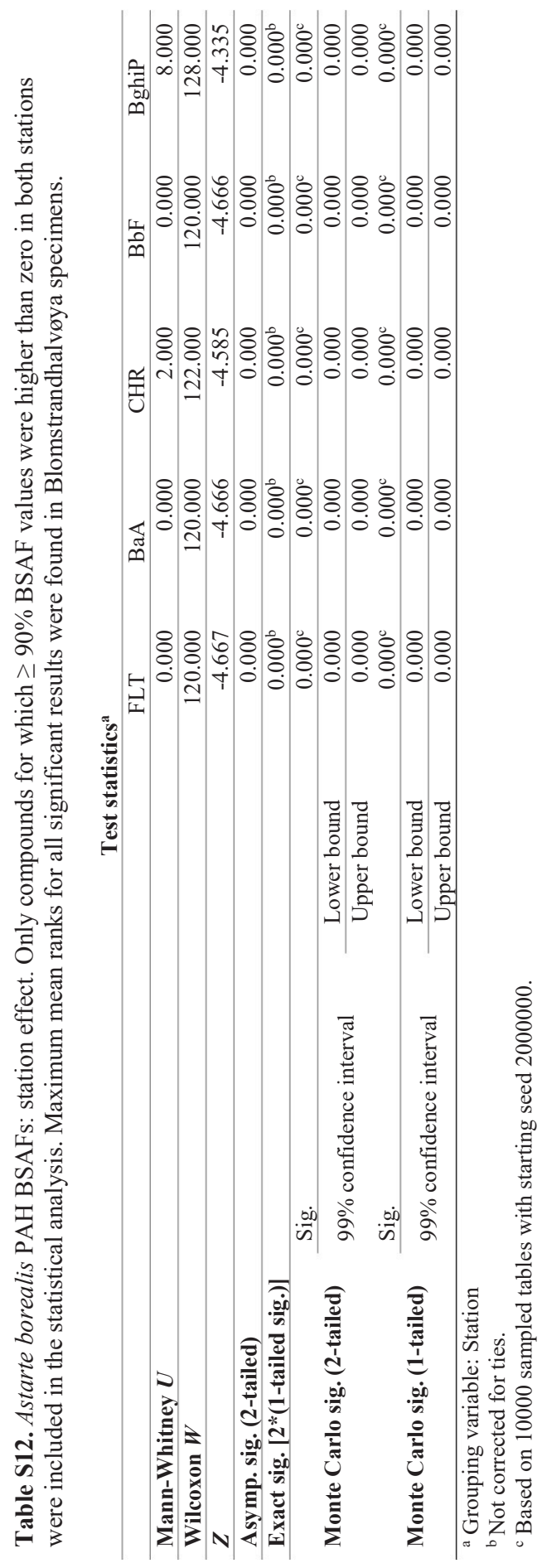


Chapter 2

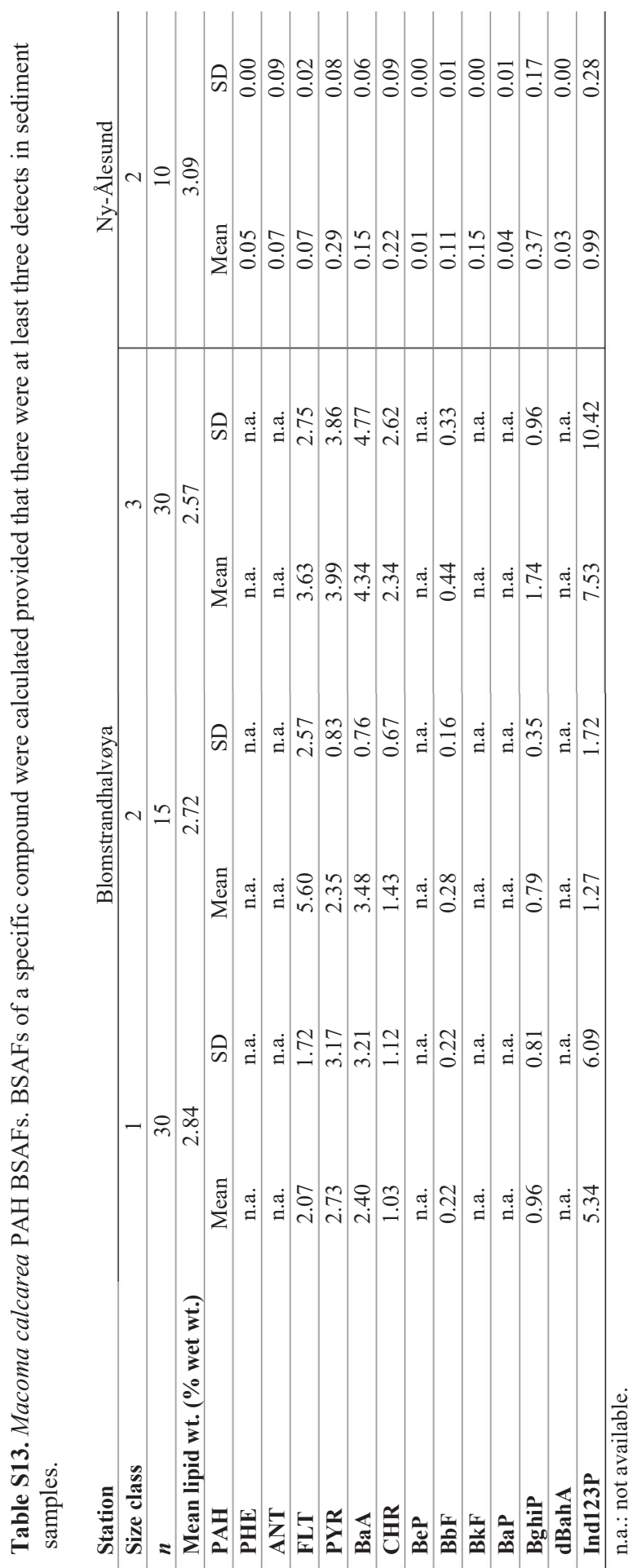




\section{Chapter 2}

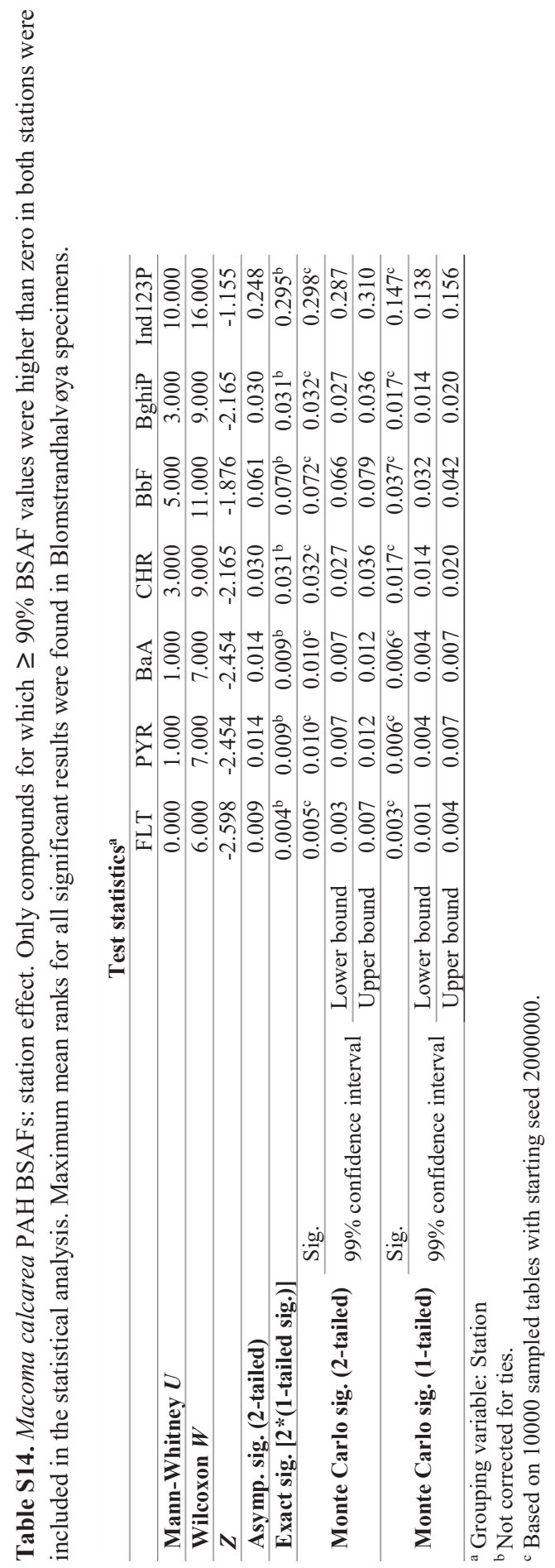

$\oplus$ 
Chapter 2

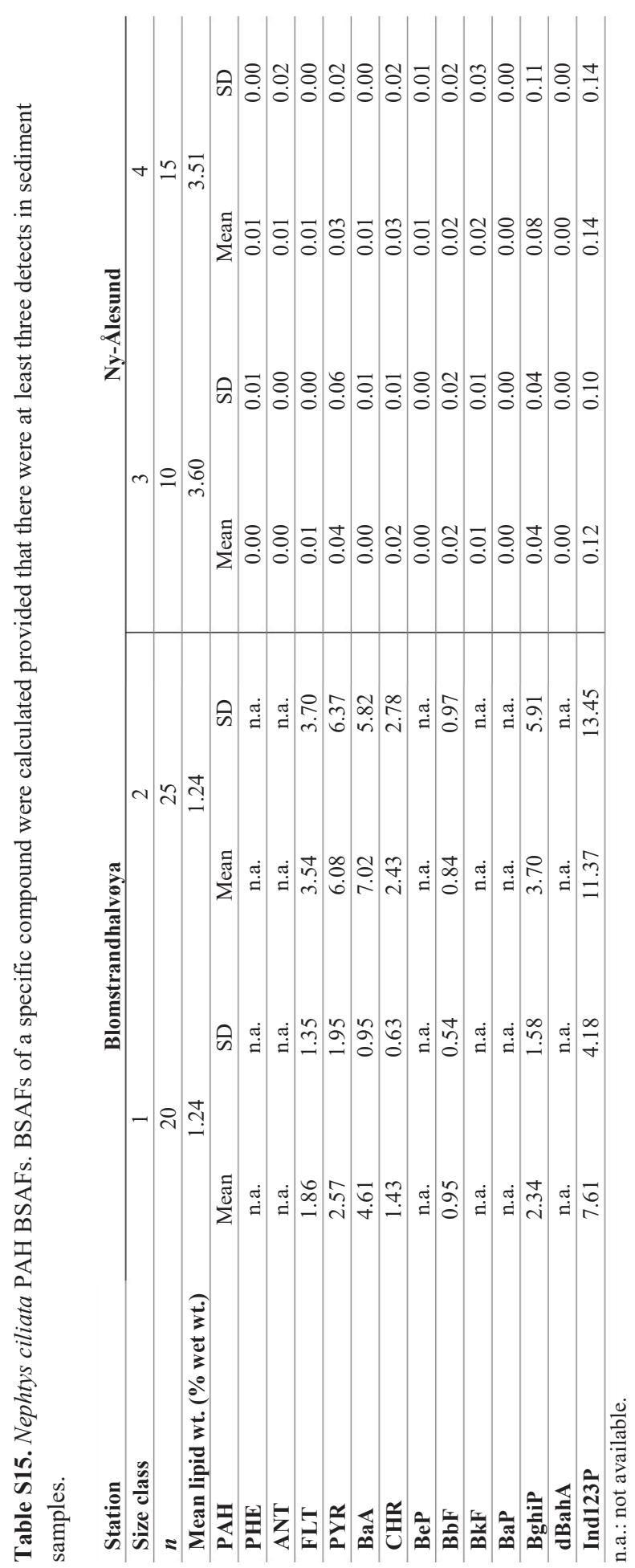




\section{Chapter 2}

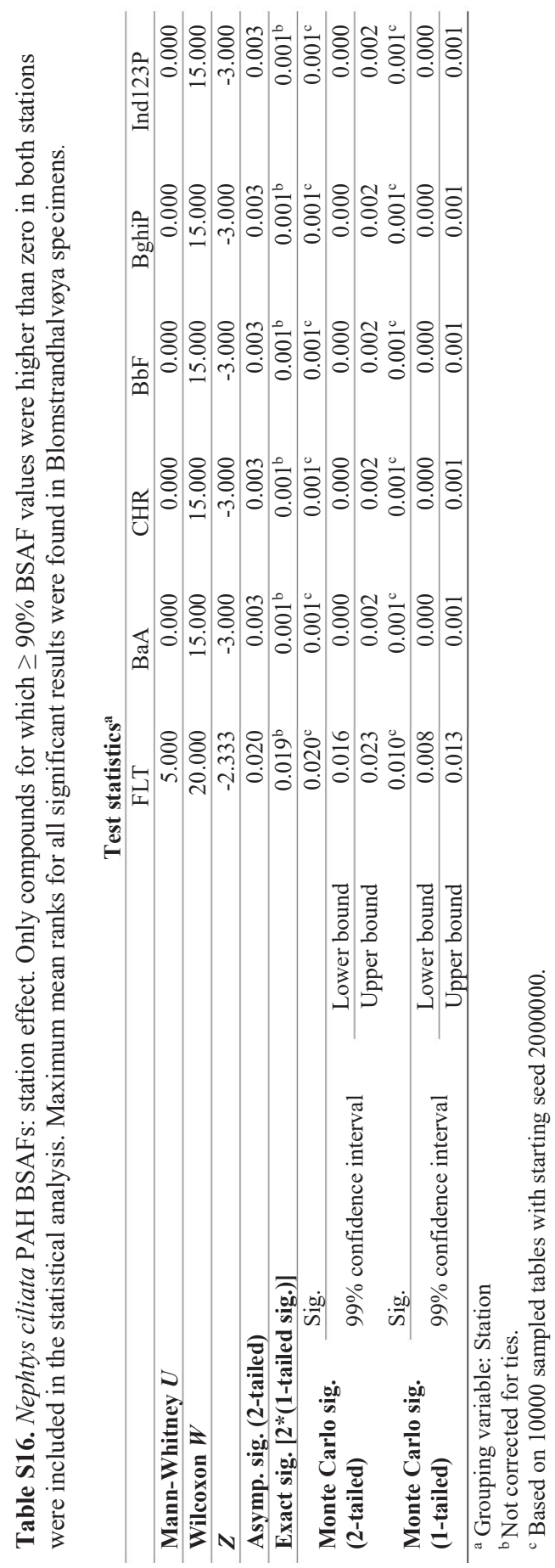




\section{Bioaccumulation of polycyclic aromatic hydrocarbons by Arctic and temperate benthic species}

Ariadna S. Szczybelski, Noël J. Diepens, Martine J. van den Heuvel-Greve,

Nico W. van den Brink \& Albert A. Koelm ans

Environmental Toxicology and Chemistry, under revision 


\title{
Chapter 3
}

\begin{abstract}
Increasing oil and gas activities $m$ ay substantialy increase chem ical stress to benthic ecosystem s in the Arctic. Polycyclic arom atic hydrocarbons (PAHs) can be used as indicator com pounds for this increase. For tem perate benthos, $m$ ore inform ation is available on the potential accum ulation of PAHs, which $\mathrm{m}$ ay be useful to address Arctic species. Here we com pare for the first tim e, the bioaccum ulation oPAHs by Arctic benthic invertebrate species, with that of tem perate invertebrate species.PAH biota-sedim ent accum ulation factors (BSAFs) ranged 0.01 to 2.48 and were generally higher in the tem perate bivalve (Limecola balthica) than in the Arctic bivalve (Macoma calcarea, ranging $0.00-0.21$ ). Arctic polychaetes (Nephtys ciliata) showed higher BSAFs $(0.00-1.79)$ than tem perate polychaetes (Alitta virens, $0.00-0.34$ ). Differences in bioaccum ulation were found am ong Arctic and tem perate species, reflecting speciesspecific feeding m odes and traits. Bioaccum ulation m odelling revealed that steady state was not likely to be reached in the 28 -d tests for all chem icals and organism sDue to low num bers of individuals, most species-specific param eters carried too $\mathrm{m}$ uch uncertainty to reveal differences between Arctic and tem perate species. No preference for ingestion of sedim ent organic $m$ atter $(\mathrm{OM})$ over that of supended $\mathrm{OM}$ was detected, indicating a high PAH affinity for OM. The results from the present study did not detect crucial differences in bioaccum ulation between tem perate and Arctic species. This $\mathrm{m}$ eans thatthere is no indication that data from tem perate spcies cannot be used as a proxy for Arctic species in risk assessm ent.
\end{abstract}




\section{Chapter 3}

\section{Introduction}

The Arctic has a high sensitivity to oil spill im pacts and has lim ited capacity for natural recovery due to a very pronounced seasonality, $m$ ainly dictated by the reduction in sea ice. Sensitivity $m$ ay be increased by expanding shipping and oil and gas $(O \& G)$ activities and the lack of appropriate oil spill response m ethods for this area[199]. Therefore, biological targets (i.e., bioindicators) for priority $\mathrm{m}$ onitoring during all phases of $\mathrm{O} \& \mathrm{G}$ activities should be used, to assess, $m$ inim ize and $m$ itigate adverse effect[199]. Polycyclic arom atic hydrocarbons (PAHs) constitute a large group of hydrophobic contam inants and have been the focus of previous environm ental assessm ents because of their potential toxicity and bioaccum ulation[23,200]. Such chem ical properties $m$ ay be used to select appropriate bioindicators of acute and chronic effects of $\mathrm{O} \& \mathrm{G}$ production.

Besides knowledge about chem ical concentrations in the abiotic environm ent, bioindicators are considered particularly useful to $\mathrm{m}$ onitor trends in $\mathrm{O} \& \mathrm{G}$ related pollution, as they integrate chem ical and nonchem ical stress and account forin situ ecological conditions [74,201]. Arctic benthic system s are characterised by a high trophic diversity, relatively long life-span and sedentary lifestyles of species [134], which $m$ akes them suitable for $m$ onitoring purposes, particularly in areas of $\mathrm{O} \& \mathrm{G}$ production. A particularly useful exposure $\mathrm{m}$ etric to define the bioindicator potential of $\mathrm{O} \& \mathrm{G}$ related bioaccum ulative chem icalin benthic invertebrates is the biota-sedim ent accum ulation factor (BSAF) of PAHs, which can adequately $m$ irror the pollution state of the local Arctic ecosystem near O\& G activitie[202]. Com pared to bioaccum ulation (i.e., net result of influx (uptake) and efflux of contam inants) by tem perate species, little is known on bioaccum ulation of PAHs from sedim ent by Arctic benthic species. Cross-chemical extrapolation techniques such as read-across $\mathrm{m}$ ay help to predict PAH bioaccum ulation by Arctic species in the absence of experim ental data[203]. If bioaccum ulation would be com parable between Arctic and tem perate species with sim ilar traits, risk assessm ent for the Arctic $m$ ight be sin plified by using tem perate species data as a surrogate for Arctic species. Therefore, it is useful to explore (a) the potential for reading across Arctic and tem perate species and (b) the potential for reading across species with different feeding traits and from the sam e region, with respect to bioaccum ulation. Sim ilarity between Arctic and tem perate species however $m$ ay not be selfevident. For instance, exposure tim es to contam inants $m$ ay be longer in Arctic system s due to, for instance, Arctic species having a longer life-span or biological reaction tim es being generally slower in polar 


\section{Chapter 3}

biota than in tem perate biota[125]. Clearance of PAHs and their $m$ etabolites $m$ ay also be slower in Arctic invertebrates, since chem ical elim ination rates aretem peraturedependent and affected by seasonal variability in lipid content [14]. Finally, seasonality in the environm ental conditions in the Arctic $m$ ay have a m ajor im pacon the physiology of local species [36].

The BSAF has traditionally been used as a $m$ etric to assess the bioaccum ulation of contam inants from sedim ent and has been com pared across a wide rargof aquatic ecosystem s[80-82]. If Equilibrium Partitioning Theory (EPT) applies, BSAF values can be expected to range between 1 and 2 [204]. This is based on the assum ption that chem icals partition between biota lipids and sedim ent organic carbon. However, EPT does not consider the possibility of feeding as a route of uptake leading to higher than equilibrium steadystate concentrations. In order to accom m odate such situations where EPT does not apply, a kinetic BSAF $m$ odel was used [5683]. Potentially, the BSAF $m$ ay be a useful $m$ etric to com pare effects of species traits on bioaccum ulation, because it can correct for differences in chem ical concentration, sedim ent organic m atter (OM) as well as organism lipid content between the sites or species that are com pared. For benthic invertebrates, of which thegeographic distribution can span to (sub-)Arctic areas, we are aware of only two studies reporting BSAFs [143, Chapter 2].

The objective of the present study is to com pare bioaccum ulation betweenfour Arctic and two tem perate species, with different species traits, using 28 d whole-sedim ent tests[56,83]. An additional objective was to assess whether the results can be generalized by using a tim e dependent BSAF m odel, previously used for describing bioaccum ulation in tem perate $\mathrm{m}$ arine and freshwater benthic invertebrates $[56,83]$. For the first tim e, we explore to what extent BSAF is useful as a m etric for bioaccum ulaiton in Arctic benthic invertebrate species and for conducting a com parison between Arctic and tem perate species for bioaccum ulation.

\section{Materials and Methods}

Based on their feeding habits, sessility and relative abundance [144], four Arctic benthic species were selected; three bivalve species: Astarte borealis (Schum acher, 1817),Macoma calcarea (Gm elin, 1791),Nuculana pernula (O.F. Müller, 1771) and a polychaete species: Nephtys ciliata (O.F. Müller, 1776). These species are prim arily abundant in Arctic clim ate zones, although they are not restricted to this area (Table S1). Additionally, two tem perate benthic species (a bivalve: Limecola balthica [Linnaeus, 1758] and a polychaete: Alitta virens 
[Sars, 1835], form erly known asMacoma balthica and Nereis virens) were selected based on their com parable feeding habits, sessility, availability of chronic test protocols and thus the potential for a com parison with the Arctic species. We Im ited the present study to two tem perate species because we prioritized com paring bioaccum ulation am ong Arctic and tem perate deposit feeding bivalves and polychaetes. Due to scarcity of $M$. calcarea individuals at the sam pling area, a second Arctic depositfeeder (N. pernula) was included. Since $M$. calcarea $\mathrm{m}$ ay feed both on suspended and sedim ent OM, an obligate suspension feeder (A. borealis) was also included to estim ate the contribution of suspended OM to the bioaccum ulation of PAHs byM. calcarea.

\subsection{Test organisms}

We perform ed a $28 d$ sedim ent bioaccum ulation experim ent, with Arctic species and conditions at Kings Bay AS (Ny-Ålesund, Svalbard) between Septem ber and October 2014, here onwards named as "AE" (Arctic Experiment); and one with temperate species and conditions at Wageningen Marine Research (Yerseke, the Netherlands) between July and August 2014, here onwards named as "TE" (Temperate Experiment). Sediments in the Arctic (AE) and tem perate (TE) experim ents were the sam e for the sam e phylum . Emapis was on sim ulating environm entally realistic PAH exposure levels, which im plied use of representative species of the $\mathrm{m}$ acrobenthic com $\mathrm{m}$ unity of each clim ate region and fietd contam inated sedim ents. This also im plied that som etim es num bers of individsıakere too low to allow for testing all sedim ent treatm ents. This is a lim itation inherent to Arctic $\mathrm{m}$ arine ecological research.

Perm ission for sam pling of Arctic and tem perate species was issued by The Governor of Svalbard and the Province of Zeeland, respectively. Sam pling of Arctic species was perform ed along a transect from Tønsneset (790'22"N, 11 $\left.57^{\prime} 10^{\prime \prime} \mathrm{E}\right)$ to Blom strandhalvøya

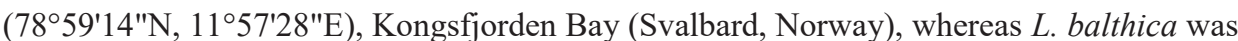
collected at low tide at the Oesterdam (The Netherlands, 51 $26^{\prime} 24^{\prime \prime} \mathrm{N}, 4^{\circ} 13^{\prime} 16^{\prime \prime} \mathrm{E}$ ). A. virens was obtained from a professional bait farm, Topsy baits (Wilhelm inadorp, the Netherlands). Arctic and tem perate species were acclim atized under test conditions. Arctic species were kept in filtered natural sea water $(20 \mu \mathrm{m})$ during 2 to $6 \mathrm{~d}$ without food supply, whereas in the TE experim ent anim als were kept in filtered natural seawater $(0.2 \mu \mathrm{m})$ during $5 \mathrm{~d}$ and were fed once at the start of the acclim atization. For further details of the acclim atization of $₫$ st species and sedim ent collection, see the Supporting Inform ation (SI). 


\section{Chapter 3}

\subsection{Sediment treatments preparation}

Since both $A$. borealis and $M$. calcarea usually reside in sandy sedim ent and $N$. ciliata is generally found in sandy $\mathrm{m}$ ud[40], two different batches of sedim ent were prepared after sedim ent collection to ensure an optimal habitat for the test species. Each contained different ratios of m uddy and coarse sedim ent, respectively defined as $\varangle 0.5$ and $0.5-1 \mathrm{~m} \mathrm{~m}$ grain size. Bivalves sedim ent (BS) contained twothirds of coarse and one-third of m uddy sedim ent, whereas polychaetes sedim ent (PS) contained twothirds of m uddy and onethird of coarse sedim ent, based on volum e. Sedim ent was collected in the Oosterschelde estuary (The Netherlands, 51 $\left.{ }^{\circ} 36^{\prime} 13.5^{\prime \prime} \mathrm{N}, 3^{\circ} 47^{\prime} 49.3^{\prime \prime E}\right)$ on 24 to 25 April 2014 and 2 May 2014 and used to create the sedim ent treatm ents for both the $\mathrm{AE}$ and $\mathrm{TE}$ experim ents. This was done to ensure hom ogeneity of exposure of treatm ents am ong experim ents. These sedim ent $m$ ixtures contain background PAH levels and therefore are referred to as the 'low' (L) treatment hereafter (BSL, PSL). PAH concentrations differed between BSL and PSL treatm ents (Tables S2 and S3) due to differences in their m ud content and other variables creating sedim ent heterogeneity, and were one order of $\mathrm{m}$ agnitude higher than in sedim ent previously colected at the Arctic species collection site (Blom strandhalvøya)(Chapter 2).

From each of these two initial batches with low chem ical concentration, another two sedim ent treatments were prepared with a higher chemical concentration, referred to as the 'medium' (M) and 'high' (H) concentration. The 'medium' treatment contained 5\% (vol.) of harbour sediment (Rotterdam, the Netherlands), while the 'high' treatment contained 10\% (vol.) of harbour sedim ent. These percentages were used (a) on a precautionary basis since neither the harbour sedim ent chem ical concentrations nor the effect threshold for each of the species were known and (b) to be able to link non-lethal effects of chem ical concentration to endpoints studied (Chapter 4). These preparations thus resulted in six sedim ents: three for bivalves (BSL, BSM, BSH) and three for polychaetes (PSL, PSM, PSH) (Figure S1). All sedim ent treatm ents were thoroughly $\mathrm{m}$ ixed with a turbine $\mathrm{m}$ ixer for approxim ately $15 \mathrm{~m}$ in before storage/transport from the Netherlands to Svabard and again right before use in the exposure experim ents. Of all sedim ent treatm ents, chem ical concentrations and other chacheristics (i.e., dry wt. and OM content) were assessed (Tables S2 and S3). Due to logistics, storage tim e $\left(3-7^{\circ} \mathrm{C}\right)$ for sediment treatm ents was 9 weekslonger in the AE than in the TE experim ent. Prior to start of exposure, sedim ent treatm ents were allowed to stay in contact with filtered sea water in a 1:6 sedim entto-water volum e ratiowithout aeration for $3 \mathrm{~d}$ and 
with aeration for the following $4 \mathrm{~d}$. Som e experim ental units in the AE experim ent were aerated for 12 to $17 \mathrm{~d}$ because biota field sam pling took place for a longer period than initially expected (the first 3 weeks since the aeration started).

\subsection{Experimental design}

Experim ental designs were sim ilar for $\mathrm{AE}$ and TE except for am bient tem perature and photoperiod. The AE experim ent was a $28 \mathrm{~d}$ test in a tem perature controlled room at $3{ }^{\circ} \mathrm{C}$ under a photoperiod of $12 \mathrm{~h}$ light: $12 \mathrm{~h}$ dark. All planned sedim ent treatm ents were runwith $N$. ciliata (PSL, PSM and PSH) ( $n=1-3$; Table S4). However, due to low num bers of available organism s, only two treatm ents (BSL and BSH) were tested withM. calcarea $(n=1$ $-2)$ and only one treatm ent (BSH) was tested withA. borealis and $N$. pernula $(n=2-3$; Table S4).

The TE experim ent was a $28 \mathrm{~d}$ test in a tem perature controlled room at $18^{\circ} \mathrm{C}$ under a photoperiod of $16 \mathrm{~h}$ light: $8 \mathrm{~h}$ dark. All sedim ent treatm ents were tested with $A$. virens (PSL, PSM and PSH) $(n=2-3)$. Due to low availability of test organism s only two treatm ents were tested with L. balthica (BSL and BSH) $(n=1-3)$.

For statistical purposes, only m easured data for BSH and PSH treatm ents were used due to either a low level of replication of BSL and PSM treatm ents (Table S4) orthe heterogeneity am ong PSL replicates in their OM content (Tables S2 and S3). Data for all treatm ents were used for bioaccum ulation m odelling.

Individuals were random ly divided in groups of 16 to 50 individuals per experim ental unit (Table S4). Anim als were not fed during exposure, although sedim ent OM content (2-6\%) and in som e cases food supply during acclim atization (i.e., tem perate species) prevented body [56] and lipid weight loss (Tables S5 and S6) during the experim ent.

\subsection{Endpoints}

Prior to the start and at end of the experim ents, organism s were allowed to depurate their guts for $24 \mathrm{~h}$ in filtered sea water. At the end of each experim ent, anim als were weighed, m easured for body or shell length, dissected (e.g., bivalves) and pooled by species. Sam ples were stored at $-20^{\circ} \mathrm{C}$ for later determ ination of wet ut. and lipid fraction, expressed as $\%$ wet wt., and chem ical concentrations $(\mu \mathrm{g} / \mathrm{kg}$ wet wt.). Experim ental units were checked daily for $\mathrm{m}$ ortality (i.e., anim als at surface and im $\mathrm{m}$ obile after poked), and dead organism s were rem oved daily. 


\section{Chapter 3}

At the start of the AE experim ent only subsam ples of $A$. borealis and $N$. pernula were archived, to assess the initial conditions ('Background'). This was however, not feasible for M. calcarea and N. ciliata due to the low num ber of individuals. At the end of the experim ents, sam ples of each sedim ent treatm ent were stored $\mathrm{a} 20{ }^{\circ} \mathrm{C}$ for later determ ination of dry wt., OM content and chem ical concentrations ( $\mu \mathrm{g} / \mathrm{kg}$ dry wt.). Sedim ent sam ples were also taken at the beginning of the AE experim ent (Table S2). Biota and sedim ent sam ples from both experim ents were shipped frozen in dryice to Wageningen University (Wageningen, the Netherlands) for chem ical analysis.

\subsection{Chemical analysis}

Chem ical analysis was conducted according to m ethods used byKupryianchyk et al. [150]. The following PAHs were analysed: Phenanthrene (PHE), Anthracene (ANT), Fluoranthene (FLT), Pyrene (PYR), Benz(a)anthracene (BaA), Chrysene (CHR), Benzo(e)pyrene (BeP), Benzo(b)fluoranthene (BbF), Benzo(k)fluoranthene (BkF), Benzo(a)pyrene (BaP), Benzo(ghi)perylene (BghiP), Dibenz(a,h)anthracene (dBahA) and Indeno(1,2,3-cd)pyrene (Ind123P). PAH recoveries were 85 to $94 \%$ and 64 to $75 \%$ for biota and sedim ent sam ples, respectively. Three blanks per each batch of 30 sam ples were used, and values were corrected for blanks. Benzo(k)fluoranthene and benzo(a)pyrene could not be accurately determ ined due to overlapped retention tim es with an unknown com poundFor further details on extraction, clean-up and instrum ental analysis see the SI.

\subsection{Data analyses}

Lipid-norm alisedconcentrations after $28 \mathrm{~d}$ were calculated in biota sam ples for all available sedim ent treatm ents. Biotasedim ent accum ulation factors were calculated as $\left(\mathrm{C}_{\text {org }} / f_{\text {lip }}\right) /\left(\mathrm{C}_{\text {sed }} / \mathrm{foC}_{\mathrm{O}}\right)$ with $\mathrm{C}_{\text {org }}$ being the chem ical concentrationin the organism $(\mu \mathrm{g} / \mathrm{kg}$ wet wt.), $\mathrm{C}_{\text {sed }}$ the chem ical concentration in sedim ent $\left(\mathrm{kg} / \mathrm{kg}\right.$ dry wt.), $\mathrm{f}_{\text {lip }}$ the fraction of lipids in the organism based on wet weight and $f_{c}$ the fraction of sedim ent organic carbon (OC) based on loss of ignition and an OC/OM conversion ratio of $0.4[56,83]$. Lipid-norm alised biota concentrations and BSAFs of BSH exposed bivalves and PSH exposed polychaetes were checked for norm ality with QQ plots and Shapiro-Wilk test and equality of variances with Levene's test. If data were norm ally distributed lipid-norm alised biota concentrations and BSAFs were tested for species and clim ate region effect with a oneway ANOVA or an independent $t$ test, respectively, for each PAH com pound. If data were nonnorm ally 
distributed, these were log-transform ed, and in case a norm al distribution still was not reached, lipid-norm alised biota concentrations and BSAFs were tested for species and clim ate region effect with the Kruskal-Wallis test and Mann-Whitney $U$ test in com binationwith Kolm ogorov-Sm irnovZ test, respectively, for each PAH com pound Significance level of an overall statistical com parison was set at $p \leq 0.05$, while for pairwise com parisons am ong species or chem icals the Bonferroni and Holm 's sequential Bonferroni corrections were applied, respectively. All statistical calculations were perform ed using SPSS version 22.

\subsection{Bioaccumulation modelling}

The usefulness of m odeling bioaccum ulation in invertebrate lipids was explored according to $m$ ethods described inDiepens et al. [56], following previously published m odels (e.g.,[205]). In short:

$B S A F_{t}=\frac{C_{L, t=0}}{C_{O C, t=0}^{S E D}} \times e^{-\left(k_{e}+k_{g}\right) t}+\frac{\frac{k_{e} \times K_{l i p}}{K_{O C}^{S E D}}+\alpha \times I \times[\beta+(1-\beta) \times \gamma]}{\left(k_{e}+k_{g}\right)} \times\left(1-e^{-\left(k_{e}+k_{g}\right) \times t}\right)$

in which $C_{L, t=0}\left(\mu \mathrm{g} \times \mathrm{kg}^{-1}\right)$ is the measured concentration in the biota at tim e zero,norm alised to lipid content, $C_{O C, t=0}^{S E D}\left(\mu \mathrm{g} \times \mathrm{kg}^{-1}\right)$ is the m easured concentration in sedim ent at tim e zero, norm alisedto OC content, $t(\mathrm{~d})$ is tim e, $k_{e}$ and $k_{g}\left(\mathrm{~d}^{-1}\right)$ are the rate constants for overall elim ination and growth dilution, $K_{l i p}$ is the ratio $k_{w} / k_{e}$ which equates to an apparent lipidwater partition coefficient, and $k_{w}$ the rate constant for derm al uptake $\left(\mathrm{L} \times \mathrm{kg}^{-1} \times \mathrm{d}^{-1}\right), \alpha(-)$ is the chem ical assim ilation efficiency (assum ed to be indepedent of food source) and $I(\geq 0$, $\mathrm{kg}_{\mathrm{OC}} \times \mathrm{kg}_{\text {Lipids }}{ }^{-1} \times \mathrm{d}^{-1}$ ) represents the $\mathrm{m}$ ass of ingested OC per unit of tim e and organism lipid weight, $\beta(0<\beta<1)$ is the fraction of ingested OC originating from the sedim ent, whereas 1$\beta$ is the fraction of ingested $\mathrm{OC}$ originating from the suspended and freshly deposited (sedim ent top layer) solids, and $\gamma$ is a constant ratio between the sorption affinities for suspended OC and sedim ent OC $\left(K_{O C}^{S S}=\gamma K_{O C}^{S E D}\right)$. Note that Eq. (1) m odels an OC based BSAF, whereas Diepens et al. [56] used a sim ilar version yetnorm alisedon OM. The ingested OC is thus allowed to originate partly from suppended solids (SS) from the overlying water and partly from the sedim ent (SED). Ingestion of $m$ ultiple food item $\mathrm{s}$ by benthic invertebrates has been $\mathrm{m}$ odelkd before in a sim ilar $\mathrm{m}$ anner $[56,80,83]$.

The param etrization process and calculations of the percentage of uptake through water and of the fraction of steady state reached in the bioaccum ulation test have been described before 


\section{Chapter 3}

$[56,83]$ and are provided in the SI. For further explanation of m odeling and calculation of $90 \%$ Confidence Intervals (CIs) the reader is referred to the SI.

\section{Results and Discussion}

\subsection{PAH background concentrations}

In the Arctic bivalve $A$. borealis average $\Sigma_{13} \mathrm{PAH}$ concentrations when the anim als were collected were $9.4 \mathrm{~m} \mathrm{~g} / \mathrm{kg}$ lipid wt. This was 9 tim es higher than inA. borealis individuals collected by Szczybelski et al. (Chapter 2) at the sam e sam pling area (Blom strandhalvøya) in July 2013 (Figure S4; Table S10). Concentrations of PHE and CHR were highest (46\% of the $\left.\Sigma_{13} \mathrm{PAH}\right)$ in $A$. borealis collected in Septem ber, whereas individuals collected in July accum ulated PHE and PYR ( $46 \%$ of the $\Sigma_{13} \mathrm{PAH}$ ) which was sim ilar to concentrations analysed in local sedim ents bySzczybelski et al. (Chapter 2). Changes of an order of $\mathrm{m}$ agnitude in PAH concentrations between both years were observed for PHE, ANT, CHR and BghiP. A significant increase in CHR A. borealis concentration would com ply with generally high 4-ring PAHs concentration in sedim ent surface layers from the inner areas of Kongsfjorden [206], whereas an increase in BghiP $\mathrm{m}$ ight be linked to som e disturbance of deeper layers [206] and/or deposition of terrestrial petrogenic PAHs after bedrock erosion and sedim ent transport by Blom strandhalvøya rivers and tributary stream s during late sum $\mathrm{m}$ er [207].

In the tem perate bivalve $L$. balthica average $\Sigma_{13} \mathrm{PAH}$ concentrations in individuals collected at Oesterdam (The Oosterschelde National Park, the Netherlands) were $35.5 \mathrm{~m} \mathrm{~g} / \mathrm{kg}$ lipid w.t (Table S6). Concentrations of PYR and BaA were below concentrations found in L. balthica collected in the Westerschelde estuary (The Netherlands) [208]. In the tem perate polychaete A. virens, $\Sigma_{13}$ PAH concentrations were lower than in L. balthica $(10.4 \mathrm{~m} \mathrm{~g} / \mathrm{kg}$ lipid wt.) (Table S6). This $\mathrm{m}$ ay be expected as $A$. virens were obtained from an aquaculture farm andL. balthica were collected in the field.

\subsection{Effects of Arctic species traits on PAH bioaccumulation}

Lipid-norm alised $\Sigma_{13} \mathrm{PAH}$ concentrations in Arctic invertebrates in the high treatm ent (BSH or PSH) were $13.1 \mathrm{~m} \mathrm{~g} / \mathrm{kg}$ inM. calcarea, $20.2 \mathrm{~m} \mathrm{~g} / \mathrm{kg}$ in $N$. ciliata, $37.7 \mathrm{~m} \mathrm{~g} / \mathrm{kg}$ inA. borealis and $144.8 \mathrm{~m} \mathrm{~g} / \mathrm{kg}$ in $N$. pernula (Table S5). The 3- to 4-ring PAHs were generally accum ulated by the filter feeder $A$. borealis which agreed with a higher fraction of these com pounds in 


\section{Chapter 3}

BSH sedim ent. The 5- to 6-ring PAHs were strongly accum ulated (i.e., up to one order of m agnitude higher than background concentrations)by the deposit feeder $N$. pernula which did not show this sam e agreem ent with BSH sedim ent com position. This disagreem ent $m$ ight be explained by a higher PAH accum ulation by $N$. pernula than the other two Arctic bivalves prior to the experim ent start[209], slow PAH excretion [210] and non-equilibrium between $N$. pernula lipid tissue and sedim ent during the AE experim ent.

The 3- to 4-ring PAHs (i.e., PHE, ANT, FLT and PYR) concentrations were on average 2.5 to 4 tim es higher in the BSH exposed filter feeder $A$. borealis compared to the deposit feeding bivalves (M. calcarea and N. pernula). An increase in FLT and PYR concentrations can be explained by the fact that the concentrations of these PAHs in BSH sedim ent were also high (Table S2). Concentrations of CHR were on average 42 tim es higher in BSH exposed $N$. pernula than A. borealis (Table S5), although CHR concentration in BSH sedim ent was very low (Table S2). In this case, considerably high CHR concentrations in $N$. pernula $\mathrm{m}$ ight be explained by the species ability to ingest sedim ent to a larger extent than the other Arctic bivalves [209] and to retain PAHs as observed by Neff et al. [210]. In the polychaete $N$. ciliata, differences in the concentration of PHE, FLT, PYR, BaA, BbF and BghiP between the low (PSL) and high (PSH) exposed individuals reflected the difference in concentrations $m$ easured in the PSL and PSH sedim ents (Tables S2 and S5).

No statistical differences in PAH concentrations were found between the deposit feeding bivalves M. calcarea and N. pernula in the BSH exposures. However, this conclusion should be $m$ ade with caution as the num ber of sam ples available per species was low and the two species show different feeding behaviours (Table S1; [136,209,211]). Variability in m etabolism $\curvearrowleft$ PAHs by som e of our target species (A. virens, L. balthica) is well described in the literature [139], with generally higher $m$ etabolism rates in tem perate polychaetes than bivalves. Although not evaluated in the present study, an increase in general $\mathrm{m}$ etabolic activity $[212,213]$ and a m oderate production of reactive oxygen in Arctic species at the end of sum $\mathrm{m}$ er $\{14,215] \mathrm{m}$ ay prom ote the efficiency and prevent the inhibition of PAH biotransform ation, respectively. Metabolism of PAHs in Arctic species is expected to be lower than in tem perate species due to low tem perature andgenerally low food availability $[73,104]$.

Polycyclic arom atic hydrocarbons BSAFs were generally low (1.e., BSAF $<1$ ) and higher in BSH exposed A. borealis than PSH exposed $N$. ciliata. This m ay be linked to a higher black 


\section{Chapter 3}

carbon (BC) and am orphous OM content in PSH sedim ent, which would decrease PAH bioavailability in polychaetes. Harbour sedim ents are known to contain m ore BC 53,216$]$ than sedim ents from the collection site (The Oosterschelde National Pak, the Netherlands) and the Rotterdam harbour area has been subject to considerable BC deposition[217]. The BSAFs for all PAHs ranged from $<0.0001$ to 18 , but they were often sm aller than one which is considered to be caused by the strong sorption of the planar PAHs to BC [196,218]. The 1090th percentiles of the BSAF for all PAHs in the high treatm ent (BSH or PSH) exposed biota ranged 0.02 to 1.13 for $A$. borealis, 0.01 to 0.21 for $M$. calcarea, 0.03 to 16.64 for $N$. pernula and 0.01 to 1.70 for N. ciliata (Figure 1; Table S11). The BSAFs for PHE, ANT, FLT and PYR were on average 2 to 5 tim es higher in A. borealis com pared to the deposit feeding bivalves, whereas CHR BSAFs were up to 58 tim es higher in $N$. pernula than in the other two Arctic bivalves. 

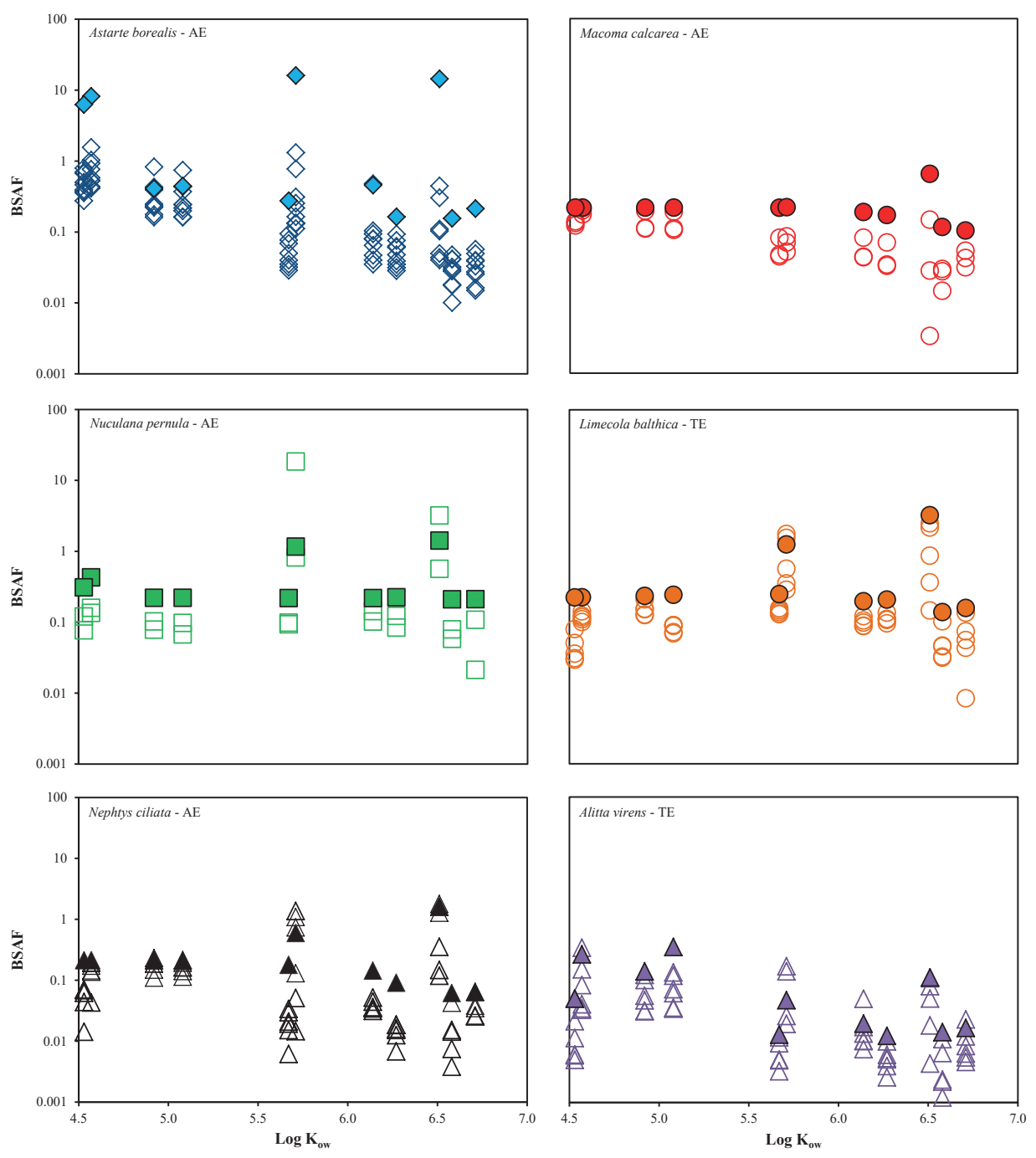

Figure 1. Modelled biota-sedim ent accum ulation factors (BSAFs) (closed sym bols) based on the minim um sum of squares and actual measured BSAFs (open sym bols) for different polycyclic arom atic hydrocarbons in Arctic and tem perate species «posed to the high treatm ent (BSH/PSH). AE: Arctic experim ent; TE: tem perate experim ent.

Significantly higher BSAFs were found for ANT in BSH exposed A. borealis than in PSH exposed N. ciliata (Tables S11 and S15). Higher PAH BSAFs in bivalves com pared to polychaetes $\mathrm{m}$ ay be explained by a higher BC content in PSH than in BSH sedim ent, which would decrease PAH bioavailability in the polychaete experim ent, and by a higher OM content in PSH than in BSH sedim ent, which $\mathrm{m}$ ay result in a higher nutritional valueof PSH 


\section{Chapter 3}

and reduction in polychaetes feeding. Both $\mathrm{BSH}$ and $\mathrm{PSH}$ treatm ents presented a sim ilar pyrogenic $\mathrm{PAH}$ com ponent, which $\mathrm{m}$ ay be indicative of $\mathrm{BC}$ presence in both sedim ent treatm ents[151].

\subsection{Effects of temperate species traits on PAH bioaccumulation}

Lipid-norm alised $\Sigma_{13} \mathrm{PAH}$ concentrations in the high treatm ent (BSH or PSH) exposed invertebrates were $32.9 \mathrm{~m} \mathrm{~g} / \mathrm{kg}$ in L. balthica and $9.4 \mathrm{~m} \mathrm{~g} / \mathrm{kg}$ in A. virens (Table S6). $L$. balthica accum ulated PAHs to a larger extent or excreted less than the polychaete $A$. virens, yet increasing PAH concentrations between the low and high treatm ent were reflected better by $A$. virens body residues. Increasing PAH concentrations in clam s and sedim ent did not correlate between the low and high treatm ents. Such lack of correlation $\mathrm{m}$ ight be explaind by other PAH uptake routes being dom inant inL. balthica such as derm al absorbance or suspended solids ingestion.

Concentrations of PAHs were significantly higher in the BSH exposed deposit feeder $L$. balthica than in the PSH exposed polychaete A. virens (Tables S6 and S17). This $\mathrm{m}$ ay be related to several factors, like higher PAH background concentrations, higher bioavailability, lower elim ination rates, longer exposure tim es and high food selectivity inL. balthica $[56,179]$.

In L. balthica, PAH concentrations were 2-fold (FLT, BbF, dBahA, Ind123P), 3-fold (PYR, $\mathrm{BeP}$ ) or 4-fold (BaA) higher in BSH than BSL individuals, whereas the concentrations were 4 to 10 tim es higher in BSH than in BSL sedim ent (Tables S3 and \$). An explanation to this disproportionality between organism $\mathrm{s}$ and sedim ent $\mathrm{m}$ ay be either a low PAH uptake from sedim ent com pared to derm al uptakẹ56,219] or differences in congener-specific absorption efficiencies from sedim ent inL. balthica [220].

In A. virens, a 2-fold increase in FLT, PYR, BeP and dBahA body residue was observed between the low and high treatm ent exposed individuals which was expected from the congeners increase between PSL and PSH sedim ent concentrations. Fluoranthene (FLT), pyrene (PYR) and benzo(e)pyrene (BeP) were also correlated between $A$. virens body residue (wet wt. basis) and sedim ent concentrations after $28 \mathrm{~d}$ of exposure to polluted sedim ents from Oslo (Norway) [221]. 
Polycyclic arom atic hydrocarbons BSAFs were higher in BSH exposed L. balthica than in PSH exposed A. virens which is likely due to differences in biota PAH background concentrations and bioavailability between sedim ent treatm ents. The 1090th percentiles for BSAFs for all PAHs in high treatm ent exposed biota ranged from 0.02 to 2.36 forl. balthica and 0.00 to 0.25 for $A$. virens (Figure 1; Table S12). Biota-sedim ent accum ulation factors were on average 1.5 to 24 tim es higher in BSH exposed $L$. balthica than in PSH exposed $A$. virens. This $\mathrm{m}$ ay be explained by a com bination of different factors such as lower PAH bioavailability in $A$. virens due to a probably higher $\mathrm{BC}$ and other organic $\mathrm{m}$ aterial content in PSH than BSH sedim ent[222], lower sedim ent ingestion by A. virens com pared toL. balthica [56] and generally higher PAH biotransform ation capacity in polychaetes[181].

\subsection{PAH bioaccumulation among Arctic and temperate species}

Lipid-norm alisedPAH concentrations were generally higher in the tem perate deposit feeding bivalve (L. balthica) than the Arctic one (M. calcarea), when exposed to the sam e sedim ent treatm ent (e.g., BSH). Only ANT concentrations were found to be 2 tim es higher in $M$. calcarea when com pared toL. balthica (Figure 2; Tables S5 and S6). This m ay be explained by the fact that tem perature affects OM-water and lipid-water partition coefficients, and thus bioaccum ulation and BSAF values if other conditions are the sam e. Lower tem perature has been found to increase PAH affinity to OM [223], and also to decrease lipid partitioning [224]. In the case of M. calcarea, these processes probably play a role but it was not possible to unam biguously identify the $\mathrm{m}$ ain reason for the apparent difference between the species. 


\section{Chapter 3}

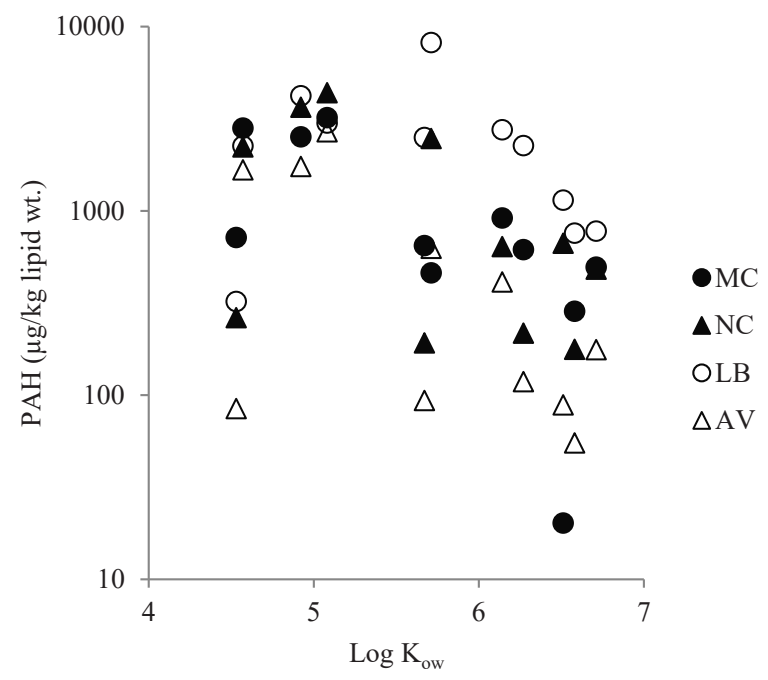

Figure 2. Geom ean polycyclic arom atic hydrocarbons (PAHs) conentrations ( $\mu \mathrm{g} / \mathrm{kg}$ lipid wt.) in Arctic and tem perate species exposed to the high treatm ent (BSH/PSH).MC: Macoma calcarea; NC: Nephtys ciliata; LB: Limecola balthica; AV: Alitta virens.

Additionally, differences between field-sam pledL. balthica and M. calcarea and differences in food selectivity $m$ ay have led to differences in their general perform ance during the TE and $\mathrm{AE}$ experim ents. For instance, in the case of $M$. calcarea, strong tem perature gradient $(0-4$ $\left.{ }^{\circ} \mathrm{C}\right)$ described at sam pling depth $(20 \mathrm{~m})$ withn a $2 \mathrm{~m}$ onth period in late sum $\mathrm{m}$ er[ 145,225$]$ could have increased energy allocation to physiological $m$ aintenance in the Arctic bivalves decreasing their energy budget $[38,226]$, whereas the absence of phytoplankton input in the experim ent can cause a rapid onset of lowered m etabolic rate inM. calcarea adults [136,227].

The Arctic polychaete (N. ciliata) showed on average 2 to 3 tim eshigher ANT, PYR, BaA and BbF concentrations than the tem perate polychaete (A. virens) (Figure 2; Tables S5 and S6). This $\mathrm{m}$ ay be related to the fact that food conversion can be $\mathrm{m}$ ore effective inN. ciliata under low tem perature com pared toA. virens [228], thus lowering energy loss and im proving the Arctic polychaete's fitness. Reproductive and morphological differences between the species can also affect their feeding activity rates and PAH bioaccum ulation. A $<12 \mathrm{~h}$ photophase is known to trigger onset of sexual $\mathrm{m}$ aturity in polychaetes and to reduce their feeding rate [229,230]. It is possible that the feeding rate for the Arctic species N. ciliata was reduced during the period of sam pling ( $8-26$ Septem ber), when the natural photophase rapidly reaches $<12 \mathrm{~h}[229,231]$. In the case of the tem perate species $A$. virens, both farm 
growing and TE conditions (photophase $>12 \mathrm{~h}, 18^{\circ} \mathrm{C}$ ) ensured gam etogenic developm ent arrest in $\mathrm{m}$ ature fem ale§ 232$]$.

Following this last assum ption, stable feeding activity would have m ade a PAH assim ilation peak possible, which in this case was assum ed to have been reached at an earlier exposure tim e in the tem perate polychaeteA. virens than in the Arctic polychaete N. ciliata. This can be due to continuous feeding by $A$. virens, which $\mathrm{m}$ ay not only increase the contact tim e of the species intestinal epithelium and coelom ic fluids with PAHs[233], and thus increase PAH solubilisation, but $\mathrm{m}$ ay also lead to oxidative stress and ultim ately to biotransform ation enzym es induction[181,234]. Nephtyidae species such as $N$. ciliata, usually have a m uch sm aller gut volum e than other deposit feeding polychaetes and take discrete $\mathrm{m}$ eals as part of their carnivore diet [235]. This $\mathrm{m}$ ay to som e extent restrict the species PAH absorption[236], although stable pre-oogenesis conditions ( $12 \mathrm{~h}$ light: $12 \mathrm{~h}$ dark) in the absence of anim al food (i.e., AE experim ental conditions), would $\mathrm{m}$ ake it necessary for the anim als to increase their deposit feeding activity over tim e in order to $\mathrm{m}$ aintain PAH tolerance $\mathrm{m}$ echanism $\mathrm{s}$. Although we have no conclusive evidence for this explanation, this could have possibly created a difference between both species so that $A$. virens energy budget at exposure start and also its PAH bioaccum ulation were higher than in $N$. ciliata.

Biota-sedim ent accum ulation factors for $z$ to 3-ring PAHs were higher in BSH exposed $M$. calcarea than in L. balthica which, sim ilarly to the differences between PAH lipid-norm alised concentrations, could be explained by higher waterborne PAH uptake in M. calcarea. Biotasedim ent accum ulation factors for PAHs were generally higher in PSH exposedN. ciliata than in A. virens. Ranges of BSAFs for all PAHs were $<0.0001$ to 18 , in the order M. calcarea $\approx$ A. virens $<A$. borealis $<N$. ciliata $<L$. balthica $<N$. pernula. However, only species exposed to the sam e sedim ent treatm ent (BSH or PSH) under different clim atic conditions (AES TE) and with the sam e feeding m odes can be directly com pared (i.e.M. calcarea vs L. balthica and $N$. ciliata vs A. virens). The BSAF 10-90th percentile ranges for all PAHs in the high treatm ent exposed biota were 0.01 to 0.21 forM. calcarea, 0.02 to 2.36 for L. balthica, 0.01 to 1.70 for $N$. ciliata and 0.00 to 0.25 for A. virens. Phenanthrene (PHE), anthracene (ANT) and fluoranthene (FLT) BSAFs were 2 to 3 tim es higher in the Arctic bivalve com pared to the tem perate one, whereas PAH BSAFs were generally 2 to 17 tim es higher in the Arctic polychaete com pared to the tem perate one (Tables S1 land S12), pointing to a generally higher PAH uptake from water in the Arctic species com pared to the tem perate ones. 


\section{Chapter 3}

\subsection{Modelling PAH bioaccumulation by Arctic andtemperate species}

The $\mathrm{m}$ odelkd BSAFs $\mathrm{m}$ atched well with the m easured BSAF data. Confidence Intervals (CIs) for $\mathrm{m}$ odelkd BSAFs however were generally wide for $\mathrm{m}$ ost param eters and species, reflecting the variability in the biological data (Figure 1; Table S21). Com plete data sets, with all treatm ents, were available for $N$. ciliata and $A$. virens and only data for the high treatm ent were present for all species. This also defines the cases for which param eters were estim ated (Table S21).

The intercept $b$ in the relation $\log K_{O C}^{S E D}=\log K_{O W}+b$, determ ining the affinity of chem ical partitioning to $\mathrm{OC}$, was optim ized to a value of $1.07(0.81-1.33 ; 90 \% \mathrm{CI})$. This is higher than the well-established value of -0.21 for natural sedim ent[237], and can be explained from PAHs being efficiently bound to BC present in the sedim ent[78,197]. This is consistent with the aforem entioned PAH diagnostic ratios indicating pyrogenic PAH sources, and with $\mathrm{m}$ any $\mathrm{m}$ easured BSAF values being sm aller than one.The sorption affinity ratio $\gamma$ was fitted and appeared indistinguishable from one, whereas the fractions of ingested sedim ent (param ete $\beta$ ) had $90 \%$ CIs extending beyond param eter constraints and were overlapping am ong species. This im plies that the present experim ents did not identifya difference in sorption to suspended $\mathrm{OM}$ and sedim ent $\mathrm{OM}$ (i.e., $K_{O C}^{S S}=K_{O C}^{S E D}$ ), and thus that it does not $\mathrm{m}$ atter what type of $\mathrm{OM}$ is ingested. Accordingly, the fraction of ingested sedim ent (param eter $\beta$ ), was set to one. This reduced the num ber of param eters fitted $k=19$; Table S21), which yielded narrower CIs for the rem aining param eters. Hence, the present m odel analysis was less rigorous as those provided by Diepens et al. [56] and Sidney et al. [83] who detected significant values for $\beta$ based on larger data sets.

In general, BSAFs decreased or rem ained at a constant value with increasing log $\mathrm{K}_{\text {ow }}$ (Figures 1 and S5), which agrees with earlier findings $[56,83]$. One explanation for this, as discussed by Diepens et al. [56], m ay be that steadystate was only reached for PHE, ANT, FLT and PYR in M. calcarea and L. balthica during the 28-d experim ent (Table S22).

However, for two chem icals (CHR and BghiP) high BSAF values were m easured and predicted, which was not in line with the other values and expected trends with $\log \mathrm{K}_{\mathrm{ow}}$. This can be explained by the high $\mathrm{CHR}$ and BghiP background concentrations in the organism s, at start of the experim ent (Tables S5and S6), and low clearance rates. 
Since particle ingestion $\mathrm{m}$ ay be a dom inant PAH uptake route in benthic organism $\$ 80]$, ingestion rates $(I)$ were fitted and expressed on an OM basis. In general, ingestion rates were low or even zero (Figure 3; Table S21). For Arctic species a low ingestion rate would be expected as $\mathrm{m}$ etabolic rates are reduced and growth rates are constrained in coldadapted stenotherm s [38]. However, com parison of the tem perate speciesL. balthica and A. virens to previously published data shows that these values are below the lower $90 \%$ CI boundary and below the range of 0.13 to $0.62 \mathrm{kgOM} \times \mathrm{kg}_{\text {Lipids }}{ }^{-1} \times \mathrm{d}^{-1}$ reported by Thom annet al. [238]. We speculate that the low apparent ingestion rates $m$ ay be caused by a high nutritional value of the sedim ent, resulting in the dom inance of derm al uptake.

For $M$. calcarea and A. borealis, the values for proportionality parameter 'a' in ' $\log k_{e}=-\log$ $\mathrm{K}_{\mathrm{ow}}+\mathrm{a}$, required to calculate the elimination rate $\left(k_{e}\right)$, were either overlapping or above previously published CIs for L. balthica, respectively (Table S21). For N. ciliata it was higher than previously published CIs for A. virens [56]. The magnitudes of 'a' for the temperate species L. balthica were higher than previously published CIs for PCBs [56,239]. For $A$. virens, magnitudes of 'a' were lower than previously published CIs for PCBs [56], whereas PAHs often are considered to be $m$ etabolised easier than PCBs $[139,181]$.

The relative im portance of chem ical uptake pathways depends on the species, the chem ical, treatm ent and estim ated value of the ingestion param eter (Table S21).nl all cases where the ingestion param eter fitted rates were zero, consequently the contribution of the OM ingestion pathway is m odeled as $0 \%$. In the high treatm ent (BSH or PSH), $N$. pernula and $A$. virens show $100 \%$ uptake from OM ingestion, whereas for A. borealis, M. calcarea and N. ciliata the m odel suggests $100 \%$ uptake from water (Table S23). Forl. balthica, the chem ical uptake from sedim ent increases with increasing $\log \mathrm{K}_{\mathrm{ww}}$. These patterns and values agree with earlier published data $[56,239,240]$. Although lower elim ination rates and ingestion rates for Arctic species com pared to their tem perate counterparts $m$ ay be expected, this cannot be seen from the present data and param eters. Because the present bioaccum ultion data set was not large enough for $\mathrm{m}$ odel validation purposes as in previous $\mathrm{m}$ odelling studies $[56,83]$, we ascribe this to the higher variability and uncertainty in the present bioaccum ulation data. 


\section{Chapter 3}
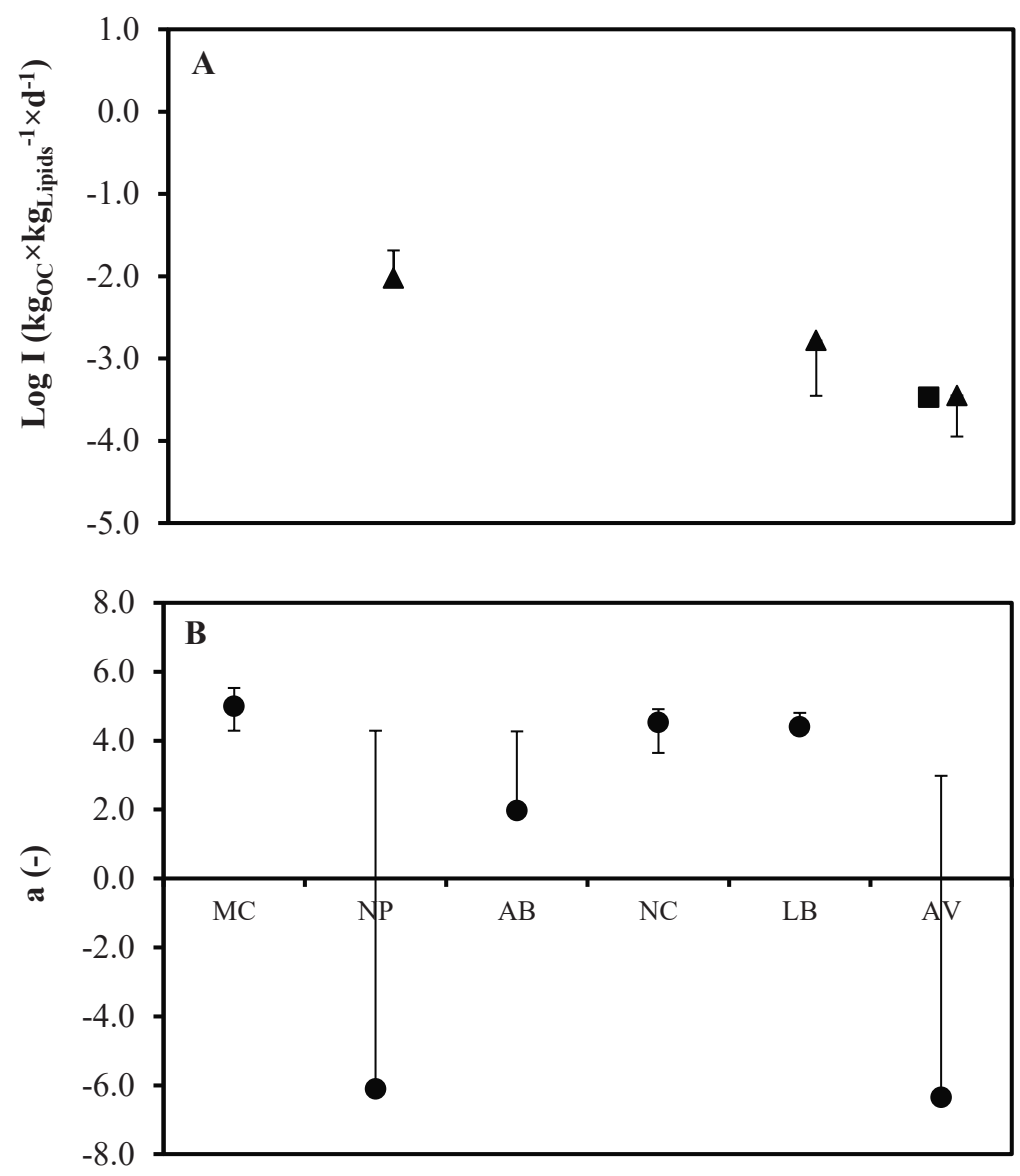

Figure 3. Optim ized m odel param eters and $90 \%$ confidence lim its (CLs) for ingestion rate (I; $\left.\mathrm{kgOC}_{\mathrm{OC}} \times \mathrm{kg}_{\mathrm{Lipids}}{ }^{-1} \times \mathrm{d}^{-1}\right)$ and intercept for elim ination rate constant $(\mathrm{k})(\mathrm{a} ;-)$. A: 'I'; B: 'a' for species exposed to the high treatment (BSH/PSH). 'I' was fitted separately for m edium (squares) and high (triangles) treatm ent. Param eter values are only included if a 90\% CL could be assessed in at least one direction. AB: Astarte borealis; MC: Macoma calcarea; NP: Nuculana pernula; NC: Nephtys ciliata; LB: Limecola balthica; AV: Alitta virens.

\section{Conclusions and Implications}

We showed significant differences in PAH bioaccum ulation am ongem peratespecies with different feeding traits, and only for ANT am ong Arctic species. Differences between Arctic and tem perate species withsim ilar feeding traits, were generally not significant. 


\section{Chapter 3}

Bioaccum ulation of PAHs from sedim entas generally higher in the Artic polychaete $N$. ciliata than in the tem perate $A$. virens. On the contrary, the tem perate deposit feeding bivalve L. balthica accum uated PAHs to a greater extent from sedim ent than its Arctic counterpartM. calcarea. Consequently, bioaccum ulation $\mathrm{m}$ etrics experim entally determ ined in tem perate species $\mathrm{m}$ ight becom e too conservative in the risk assessm ent for sim ilar Arctic species and $\mathrm{i}$ other cases too m oderate.

The tim edependent BSAF m odel shows that $\mathrm{m}$ odel param eters did not significantly differ am ong species and clim ate regions. This is supported by the generally nonsignificant differences in PAH bioaccum ulation between Arctic andtem perate species. This im plies that although m odellinghas been shown to be a valid tool in earlier work $[56,83]$, insufficient data for an appropriate param etrization lim ited the insight provided by $\mathrm{m}$ odelling inhte present study. Field validation of bioaccum ulation m odels, of which data assum ptions are built on tem perate species data, will however require Arctic standard singlespecies tests to be able to further characterize sedim ent bioaccum ulation m echanism sush as contam inant uptake and elim ination routes, under local conditions.

The present study used the sam e sedim ents and conditions $\mathrm{m}$ im icking Arctic and tem perate environm ental conditions and used Arctic and tem perate species with pairwise $m$ atching functional groups. Differences in bioaccum ulation in a direct com parison of the two clim ate regions characteristics were observed, which however were not statistically significant due to considerable variability in the biological control data, and sim ilarity in exposure routes. This $m$ eans that a cautionary note should be sounded on the use of tem perate benthic species as a surrogate for Arctic benthic species in bioaccum ulation assessm ent.

\section{Acknowledgements}

We thank Axel Meldahl (captain of the research vessel MS Teisten of Kings Bay AS [NyÅlesund, Svalbard] in sum m er 2014), Maarten Loonen, Ben Frederiks, Livia Sidney, Verena Mohaupt, Thom as Dupeyron, Kerstin Binder, Anna Rom an and Wouter van Duin for their assistance with logistics and sam pling. Maria WłodarskaKowalczuk, Monika Kędra, Hans Hillewaert and Alexander Sem enov are acknowledged for granting us perm ission to us the im age files in SI.Equinor ASA (SAP 4502687550) and the Wageningen UR TripleP@Sea innovation program $\mathrm{m}$ (KB-14-007) are acknowledged for funding the ARCIND project. 


\section{Chapter 3}

\section{Supporting Information}

\section{Field sampling}

Sampling of Arctic species. Sam pling in Kongsfjorden was m ainly perform ed near Blom strandhalvøya and to a lesser extent at Gluudneset and Tyskerhytta, Kongsfjorden Bay (Svalbard, Norway). Sam ping took place outside the protected areas of Kongsfjorden on board of research vessel MS Teisten (Kings Bay AS, Ny-Ålesund) between 8 and 26 Septem ber 2014 and within the Outer Basin com m unity distribution area as defined by Włodarska-Kowalczuk and Pearson [147]. Biota sam ples were collected using a Van Veen grab $\left(0.1 \mathrm{~m}^{2}\right)$. Four Arctic $\mathrm{m}$ arine benthic invertebrate species with different feeding behaviors were collected: Astarte borealis (m ollusc; suspension feeder [Schum acher, 1817]), Macoma calcarea (m ollusc; surface deposit and suspension feeder [Gm elin, 1791]),Nuculana pernula (m ollusc; subsurface deposit feeder [O.F. Müller, 1771]) and Nephtys ciliata (polychaete; predator [O.F. Müller, 1776]) (Table S1).

Sampling of temperate species. Limecola balthica (m ollusc; surface deposit and suspension feeder [Linnaeus, 1758]) was collected at low tide at the Oesterdam, Zeeland, the Netherlands, between 16 and 17 July 2014. Alitta virens (polychaete; predator and deposit feeder [Sars, 1835]) were obtained from a professional bait farm, Topsy baits, Wilhelm inadorp, the Netherlands (Table S1).

\section{Acclimatization}

Arctic species were kept in glass aquaria with aerated, filtered $(20 \mu \mathrm{m})$ and UV-treated sea water from the fjord $\left(3^{\circ} \mathrm{C}\right)$ for 2 to $6 \mathrm{~d}$, before start of the experim ent. In the case ofNephtys ciliata, a thin layer of sieved $(1 \mathrm{~m} \mathrm{~m} \varnothing)$ sedim ent from the original sam pling area was also included. Anim als were not fed during acclim aization.

Tem perate species were kept in glass aquaria with aerated filtered $(0.2 \mu \mathrm{m})$ sea water for $5 \mathrm{~d}$ and were fed once with spiked ground fish food (TetraMin) suspended in deionised water at the start of the acclim atization. In order to have sufficientfood supply, $10 \mathrm{~m} g$ of dry food for A. virens and $3 \mathrm{mg}$ (shell length $\geq 15 \mathrm{~m} \mathrm{~m}$ ) or $1.5 \mathrm{mg}$ (shell length $<15 \mathrm{~m} \mathrm{~m}$ ) forbalthica was added per individual. 
Water quality variables such as $\mathrm{pH}$, dissolved oxygen, salinity and tem perature were m easured every two days during exposure tim e (Tables S7and S8).

\section{Sediment collection}

A m oderately contam inated subtoxic $m$ arine sedim ent was prepared by $m$ ixing a non contaminated 'clean' sediment with a naturally contaminated harbour sediment. Batches of m uddy sedim ent (132L) and coarse sedim ent (176 L) were collected near Wissenkerke (The Oosterchelde Natural Park, the Netherlands) at low tide between 24 and 25 April 2014 and 2 May 2014. Coarse sedim ent was sieved in the field with a 1-m m sieve whereas m uddy sedim ent was seved at laboratory inside a $1-\mathrm{m} \mathrm{m}$ sieve with som e filtered sea water $(0 . \not \mathrm{m})$. Once sieved both sam ples were stored at $3{ }^{\circ} \mathrm{C}$.

A batch of harbour sedim ent (30 L) was collected near Rotterdam Nesserdijk by Nautisch Service Centrum (Rotterdam, the Netherlands)in m idtApril 2014 and sieved with a 1-m m sieve on 1 May 2014. A subsam ple of the sieved wet harbour sedim ent ( $800 \mathrm{~m} \mathrm{~L})$ was sent to Wageningen Marine Research laboratories (IJm uiden, the Netherlands)for further chem ical analyses.

\section{Test species}

Arctic experiment. A. borealis, M. calcarea, N. pernula and N. ciliata were obtained as described in the field sam pling section. A. borealis random ly selected healthy individuals with an average and standard deviation (SD) shell length of 31.30 (4.63) $\mathrm{m} \mathrm{m}$ and wet w.t(flesh) of 7.47 (4.16) g were used. $N$. pernula random ly selected healthy individuals with an average (SD) shell length of 14.60 (3.66) $\mathrm{m} \mathrm{m}$ and accum ulated $x=16-17)$ wet wt. (flesh) of 7.38 (1.65) g were used. As for M. calcarea and N. ciliata, we did not measure any m orphological param eters due to the scarcity of individuals. Anim als were not fed during the acclim atization, neither during the exposure experim ents.

Temperate experiment. L. balthica and A. virens were obtained as described in the field sam pling section. L. balthica random ly selected healthy individuals with an average (SD) shell length of $13.49(2.46) \mathrm{m} \mathrm{m}$ and wet w.t(shell + flesh) of $0.47(0.31) \mathrm{g}$ were used. $A$. virens random ly selected healthy individuals with an average (SD) lengh of $10.83(1.70) \mathrm{cm}$ and wet wt. of $2.75(0.98) \mathrm{g}$ were used. Anim als were fed once at the beginning of the acclim atization. 


\section{Chapter 3}

\section{Chemical analysis}

Subsam ples of each sedim ent sam ple were analyzed for weight percentages of organic $\mathrm{m}$ atter $(\mathrm{OM})$ content, $\mathrm{m}$ easured as loss on gnition $\left(550^{\circ} \mathrm{C}, 3 \mathrm{~h}\right)$. Biota lipids were extracted with chloroform:m ethanolwater and quantified gravim etrically.

Frozen sedim ent sam ples were thawed at room tem perature. Frozen pooled biota sam ples were thawed at room tem perature and subdivided into repleates of equal weight before drying. Sedim ent subsam ples and biota replicates were dried and grinded with diatom aceous earth and Soxhlet-extracted for $40 \mathrm{~m}$ in with hexane:acetone (3:1, v/v) (DionexASE 350 System, Therm o Scientific). Extracts were cleaneelup over an $\mathrm{Al}_{2} \mathrm{O}_{3}$ colum $\mathrm{n}$ and used for polycyclic arom atic hydrocarbons (PAHs) analysis, which was carried out on an HP 1100 HPLC equipped with a $4.6 \mathrm{~m} \mathrm{~m}$ Vydac guard and analytical reverse phase $\mathrm{C} 18$ colum $\mathrm{n}$ (201GD54T and 201TP54, respectively) which were kept at $22.00{ }^{\circ} \mathrm{C}$. Detection was perform ed by an HP $1100 \mathrm{~m}$ ultwavelength fluorescence detector operating in the $\mathrm{m}$ ulti em ission wavelength $\mathrm{m}$ ode. The $\mathrm{m}$ obile phase consisted of $\mathrm{m}$ ethanol/water ( $\mathrm{m}$ ixture and flow gradient). The injection volum e was $20 \mu \mathrm{L}$.

\section{Bioaccumulation modelling}

Bioaccum ulation m odelling was used to link observed bioaccum ulation with speciesspecific traits. Bioaccum ulation in invertebrate lipids was m odeled according to Diepens et al. [56] and is briefly described here:

$\mathrm{BSAF}_{\mathrm{t}}=\frac{C_{L, t=0}}{C_{O C, t=0}^{S E D}} \times e^{-\left(k_{e}+k_{g}\right) \times t}+\frac{\frac{k_{e} \times K_{l i p}}{K_{O C}^{S E D}}+\alpha \times I \times[\beta+(1-\beta) \times \gamma]}{\left(k_{e}+k_{g}\right)} \times\left(1-e^{-\left(k_{e}+k_{g}\right) \times t}\right)$

in which $C_{L, t=0}\left(\mu \mathrm{g} \times \mathrm{kg}^{-1}\right)$ is the m easured concentration in the biota at tim e zeronorm alised to lipid content, $C_{O C, t=0}^{S E D}\left(\mu \mathrm{g} \times \mathrm{kg}^{-1}\right)$ is the m easured concentration in sedim at at tim e zero, norm alisedto OC content, $t(\mathrm{~d})$ is tim e, $k_{e}$ and $k_{g}\left(\mathrm{~d}^{-1}\right)$ are the rate constants for overall elim ination and growth dilution, $K_{l i p}$ is the ratio $k_{w} / k_{e}$ which equates to an apparent lipid-water partition coefficient, and $k_{w}$ the rate constant for derm al uptake $\left(\mathrm{L} \times \mathrm{kg}^{-1} \times \mathrm{d}^{-1}\right), \alpha(-)$ is the chem ical assim ilation efficiency (assum ed to be independent of food source) and ( $\geq 0, \mathrm{~kg}_{\mathrm{OC}}$ $\times \mathrm{kg}_{\mathrm{LIP}} \times \mathrm{d}^{-1}$ ) represents the $\mathrm{m}$ ass of OC ingested per unit of tim e and organism lipid weight $\beta$ $(0<\beta<1)$ is the fraction of ingested OC originating from the sedim ent whereas $1-\beta$ is the fraction of ingested OC originating from the suspended and freshly deposited (sedim ent top 


\section{Chapter 3}

layer) solids and $\gamma$ is a constant ratio between the sorption affinities for suspended OC and sedim ent $\mathrm{OC}\left(K_{O C}^{S S}=\gamma K_{O C}^{S E D}\right)$. The ingested OC thus is assum ed to originate partly from suspended solids (SS) from the overlying water and partly from the sedim ent (SED). Ingestion of $\mathrm{m}$ ultiple food item $\mathrm{s}$ by benthic invertebrates has been $\mathrm{m}$ odked in a sim ilar $\mathrm{m}$ anner$[56,80,83]$. A detailed explanation of Eq. $\mathrm{S} 1$ is provided below.

The percentage of uptake through water is calculated based on Eq. S1 as:

$\%$ WaterUptake $=\frac{k_{e}}{k_{e}+\alpha I[\beta+(1-\beta) \gamma] K_{O C}^{S E D} / K_{\text {lip }}}$

The fraction of steady state reached $\left(F_{S S}, 0<F_{S S}<1\right)$ in the bioaccum ulation test $(t=28 \mathrm{~d})$ was calculated as:

$F_{S S}=1-e^{-\left(k_{e}+k_{g}\right) t}$

\section{Model parametrization}

Eq. S1 was im plem ented in Microsoft Excel and the model was fitted to the logtransform ed experim ental BSAF data using the Excel Solver tod with scaling of param eters and a relative least-squares criterion. The first term in Eq. S1 $\left(C_{L, t=0}\right)$ is om itted when concentrations in organism lipids at tim e zero are below lim it of detection. The sedim ent OGater partition coefficient $K_{O C}^{S E D}$ was assum ed proportional to $\log K_{O W}: \log K_{O C}^{S E D}=\log K_{O W}+b[241,242]$. The param eter $k_{g}$ could be obtained from either soft tissue weight differences between $t=28 \mathrm{~d}$ and $t=0 \mathrm{~d}$ for $A$. borealis (0.032), N. pernula (0.001), L. balthica (-0.001) and A. virens ($0.019)$, or estim ated from previously calculated yearly growth rates ( $\mathrm{m} \mathrm{m} /$ yeałp6,243] for M. calcarea (0.002) and $N$. ciliata (-0.001). The param eters $k_{e}, I, \beta$ and $\gamma$ were estim ated using a two-stage iterative approach [83]. First, the chem ical sorption param etersb and $\gamma$ were set at default literature values $[175,241,242]$, and the species-specific param eters $a, I$ (constrained: $I$ $\geq 0$ ) and $\beta$ (constrained: $0<\beta<1$ ) were optim ized for each species separately by $\mathrm{m}$ inim izing their individual sum of squares. Subsequently, the param eters $b$ and $\gamma$ were optim ized by $\mathrm{m}$ inim izing the total sum of squares, after which the qram eters $a, I$ and $\beta$ were fitted again for each of the species. This procedure was repeated until all $\mathrm{m}$ inim um sum $\mathrm{s}$ of squares had been reached.

Confidence intervals (90\% CIs) were calculated according to Draper and Sm ith[244]: 


\section{Chapter 3}

$S S_{90}=S S_{\min }\left(1+\frac{p}{(n-p)} F(p, n-p, 90 \%)\right)$

in which $S S_{90}$ is the sum of squares at the $90 \%$ confidence contour, $S S_{\min }$ is the $\mathrm{m}$ inim um sum of squares, $n$ is the num ber of BSAF m easurem ents $n(=479), p$ is the num ber of estim ated param eters $(p=19)$ and $F(p, n-p, 90 \%)$ is the $F$-distribution according to Fisher. Confidence intervals were estim ated using $n, p$ and $F$ either for the whole data set for the general param eters or the speciesspecific data set. Negative confidence lim its for $I$ were set to zero. Since the present experim ents did not identify a difference in sorption to suspended OC and sedim ent OC (i.e., $\left.K_{O C}^{S S}=K_{O C}^{S E D}\right)$, the fraction of ingested sedim ent $(\beta)$, was set at one. An overview of all m odel param eters is provided asTable S9. 


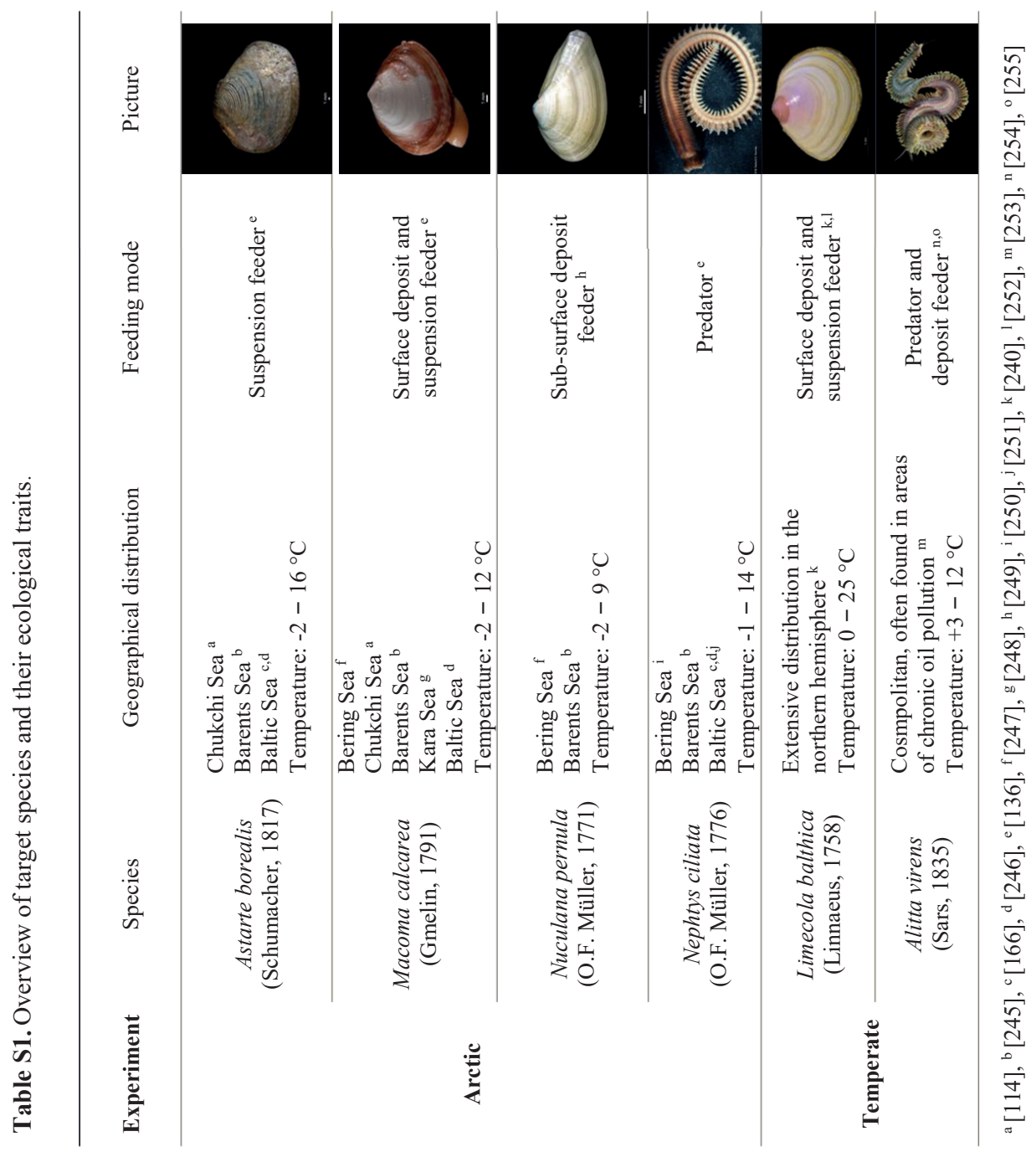




\section{Chapter 3}

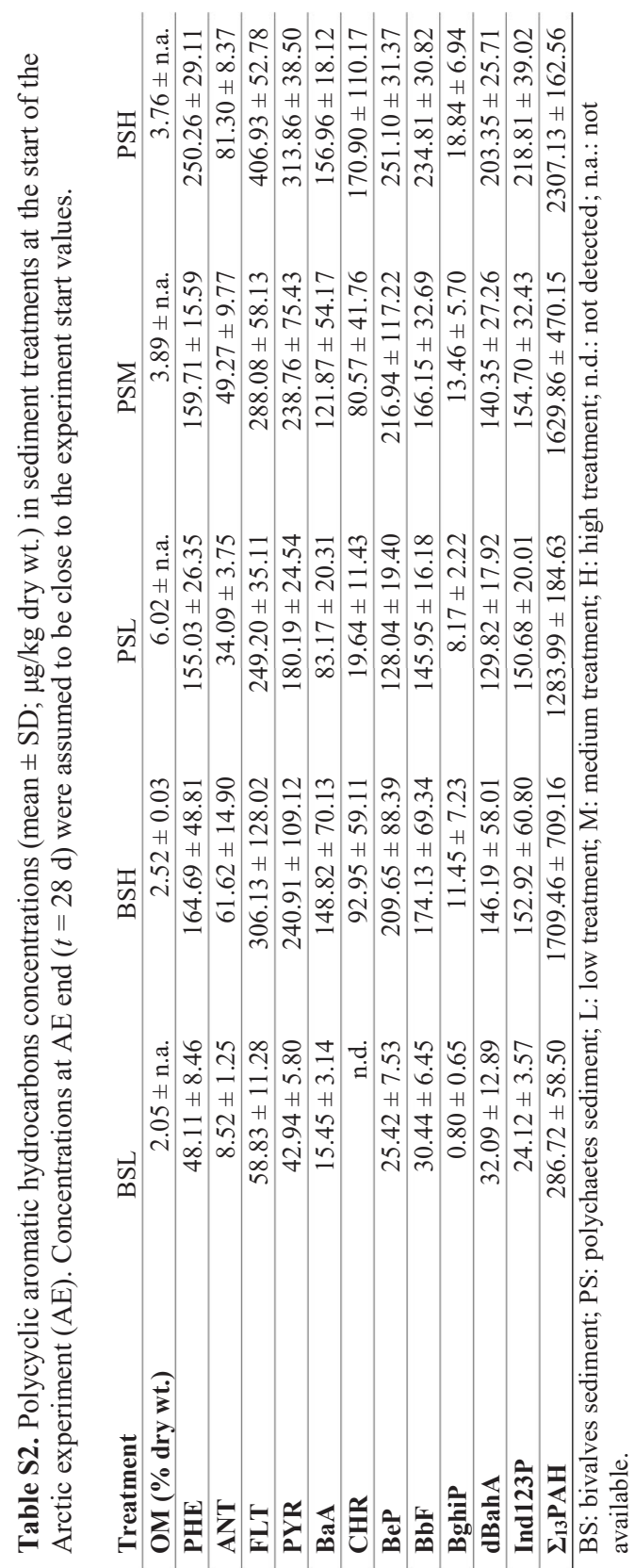

$\oplus$ 


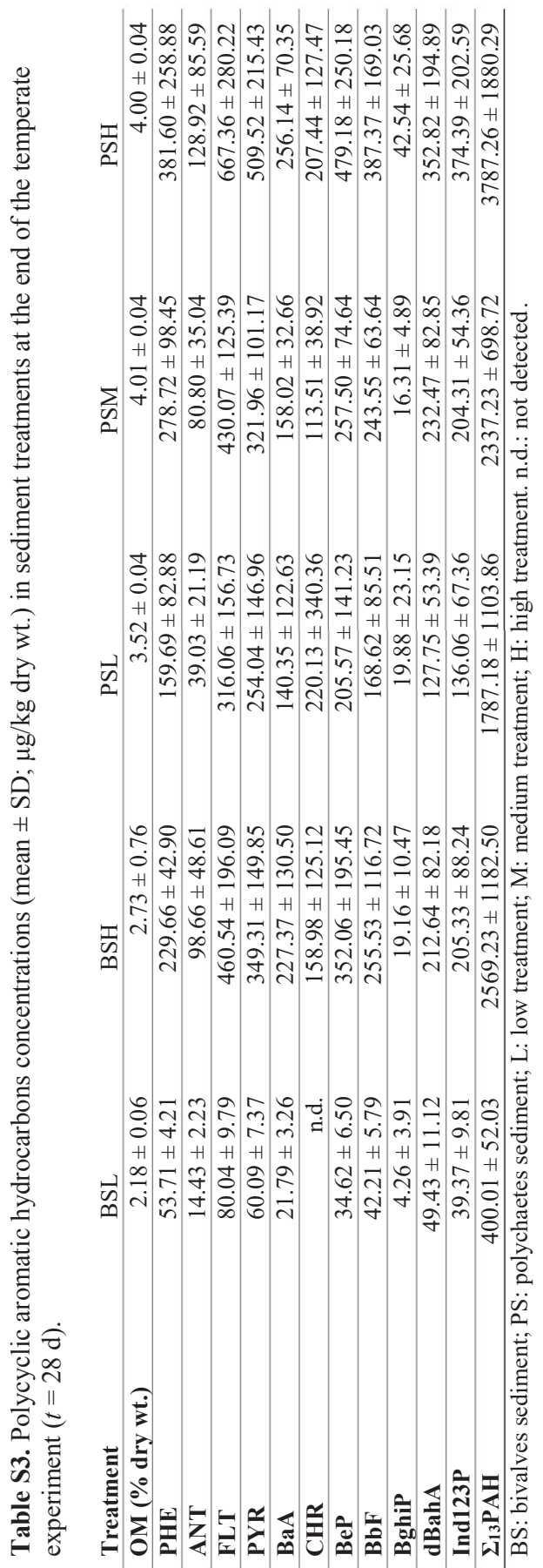




\section{Chapter 3}

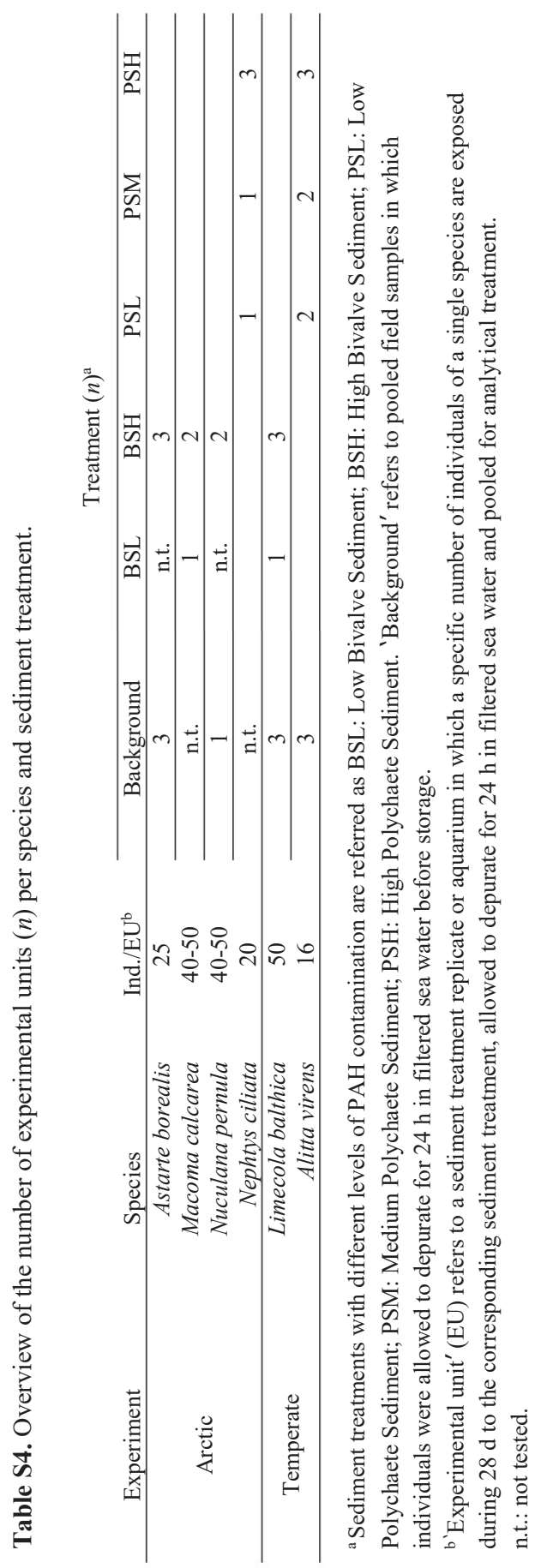




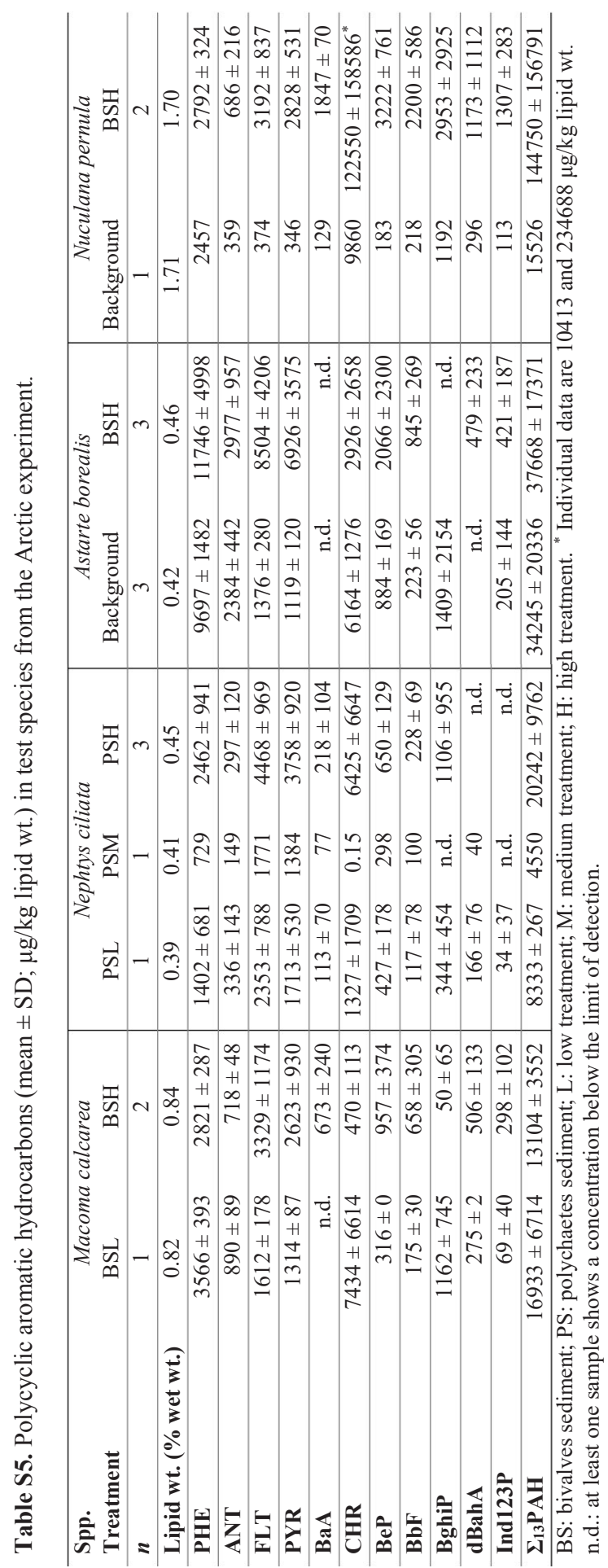




\section{Chapter 3}

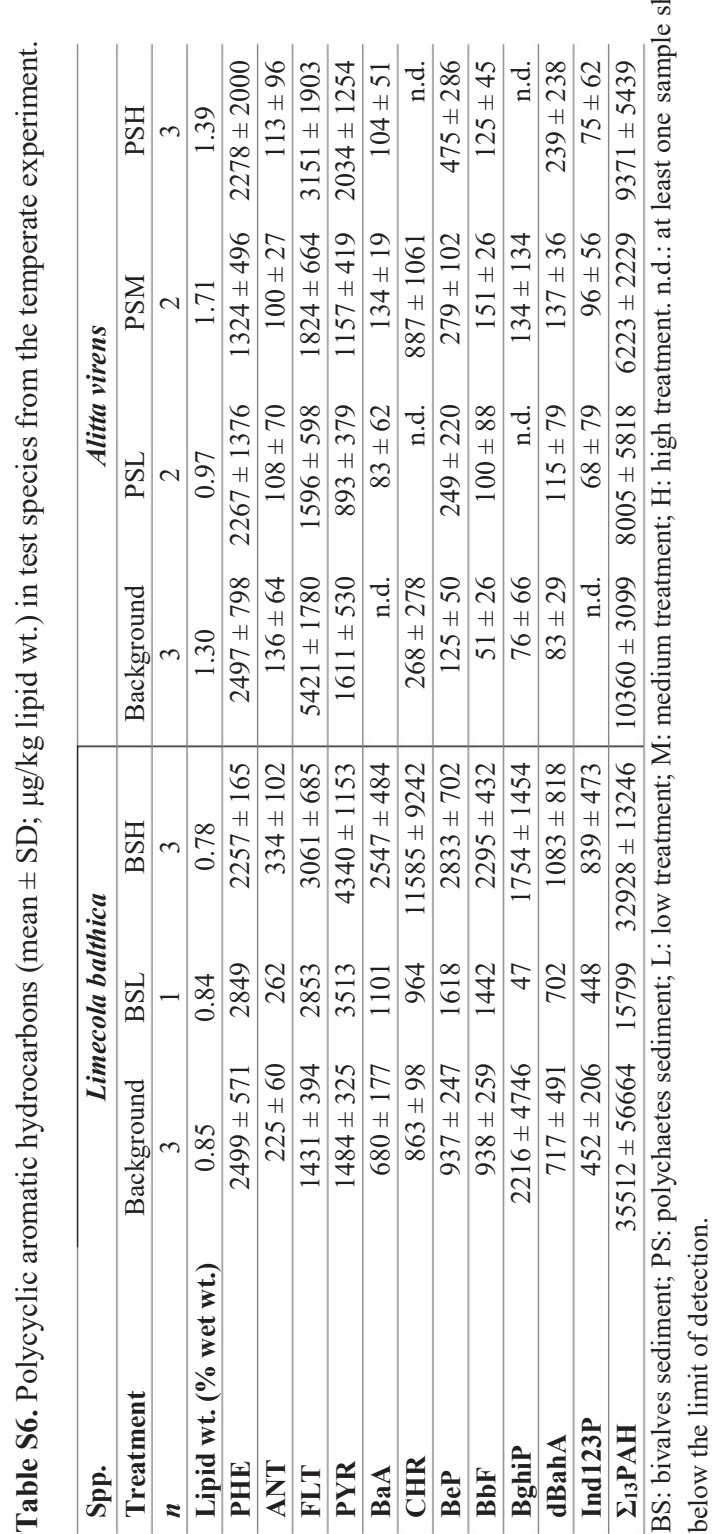

$\oplus$ 
Chapter 3

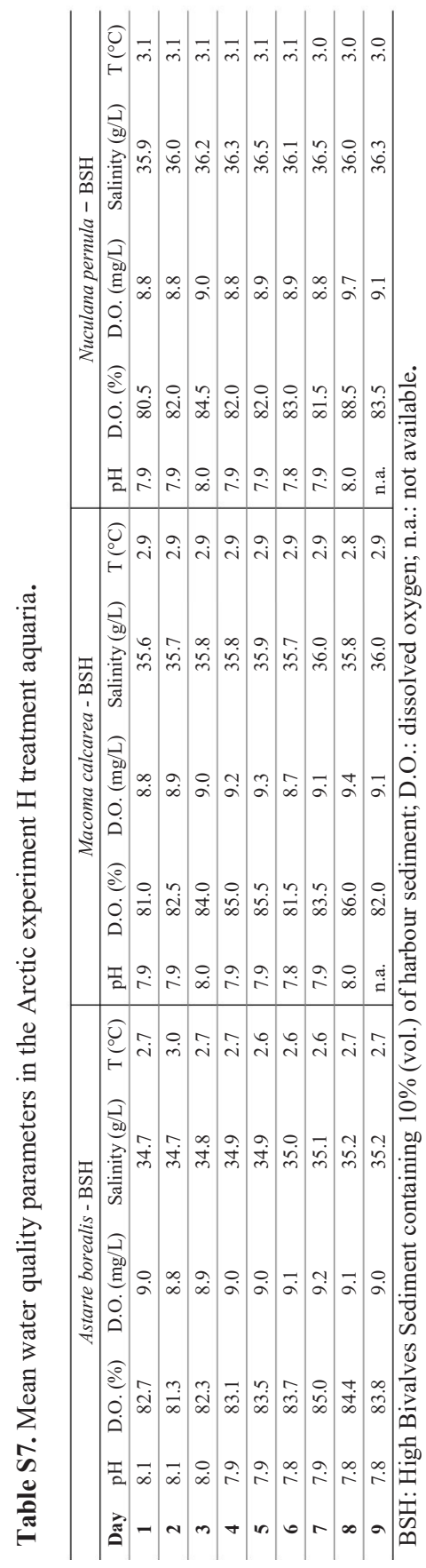

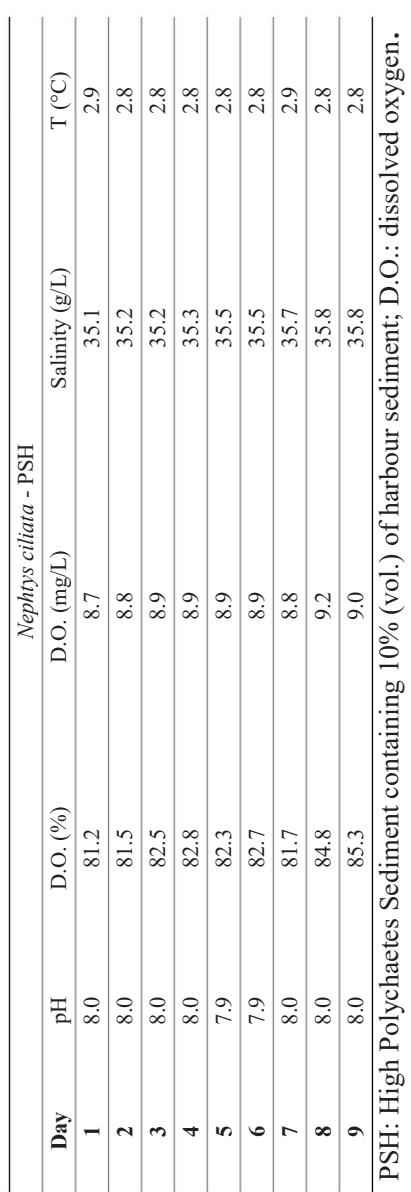

93 


\section{Chapter 3}

Table S8. Mean water quality param eters in the tem perate experim ent $\mathrm{H}$ treatm entquaria.

\begin{tabular}{cccccc|ccccc}
\hline \multicolumn{7}{c|}{ Limecola balthica - BSH } & \multicolumn{5}{c}{ Alitta virens - PSH } \\
\hline Day & $\mathrm{pH}$ & D.O. $(\%)$ & D.O. $(\mathrm{m} \mathrm{g} / \mathrm{L})$ & Salinity $(\mathrm{g} / \mathrm{L})$ & $\mathrm{T}\left({ }^{\circ} \mathrm{C}\right)$ & $\mathrm{pH}$ & D.O. $(\%)$ & D.O. $(\mathrm{m} \mathrm{g} / \mathrm{L})$ & Salinity $(\mathrm{g} / \mathrm{L})$ & $\mathrm{T}\left({ }^{\circ} \mathrm{C}\right)$ \\
\hline 1 & 8.2 & 83.8 & 6.6 & 32.8 & 17.8 & 8.1 & 79.4 & 6.2 & 33.8 & 18.1 \\
\hline 2 & n.a. & 80.3 & 6.3 & n.a. & 17.8 & n.a. & 77.9 & 6.1 & n.a. & 18.1 \\
\hline 3 & n.a. & 79.3 & 6.2 & n.a. & 17.7 & n.a. & 75.3 & 5.9 & n.a. & 17.9 \\
\hline 4 & 8.2 & 80.8 & 6.2 & 33.3 & 18.0 & 8.1 & 76.7 & 5.9 & 34.4 & 18.2 \\
\hline 5 & 8.2 & 82.0 & 6.4 & 33.5 & 18.1 & 8.2 & 78.9 & 6.1 & 34.0 & 18.2 \\
\hline 6 & 8.2 & 82.2 & 6.4 & 33.6 & 17.9 & 8.2 & 80.7 & 6.2 & 34.5 & 18.0 \\
\hline 7 & 8.3 & 84.2 & 6.5 & 34.1 & 17.8 & 8.2 & 80.9 & 6.2 & 35.2 & 18.0 \\
\hline 8 & 8.2 & 84.2 & 6.5 & 34.5 & 17.8 & 8.2 & 81.6 & 6.3 & 35.1 & 18.0 \\
\hline 9 & 8.3 & 86.0 & 6.6 & 34.7 & 18.1 & 8.2 & 79.7 & 6.0 & 35.5 & 18.3 \\
\hline 10 & 8.3 & 85.2 & 6.6 & 35.0 & 17.9 & 8.2 & 82.1 & 6.3 & 34.8 & 18.0 \\
\hline 11 & 8.3 & 85.3 & 6.6 & 35.4 & 17.9 & 8.2 & 82.4 & 6.3 & 35.2 & 18.0 \\
\hline 12 & 8.3 & 84.5 & 6.5 & 35.7 & 17.9 & 8.2 & 81.4 & 6.2 & 35.7 & 17.9 \\
\hline
\end{tabular}

BSH: High Bivalves Sedim ent containing 10\% (vol.) of harbour sedim ent; PSH: High Polychaetes Sedim ent containing $10 \%$ (vol.) of harbour sedim ent; D.O.: dissolved oxygen; n.a.: not available. 
Chapter 3

Table S9. Param eters for the biotasedim ent accum ulation factor m odel.

\begin{tabular}{|c|c|c|}
\hline Param eter & Sym bol & Unit \\
\hline $\begin{array}{l}\text { Affinity of chem ical partitioning to peat in the relation } \\
\log K_{O C}^{S E D}=\log _{O W}+\boldsymbol{b}\end{array}$ & $b$ & - \\
\hline Biota-sedim ent accum ulation factor & $B S A F_{t}$ & - \\
\hline Chem ical assim ilation efficiency & $\alpha$ & - \\
\hline Concentration in invertebrate lipids & $C_{L}$ & $\mu \mathrm{g} \times \mathrm{kg}^{-1}$ lipids \\
\hline Concentration in water & $C_{W}$ & $\mu \mathrm{g} \times \mathrm{L}^{-1}$ \\
\hline Concentration in sedim ent & $C_{O C}^{S E D}$ & $\mu \mathrm{g} \times \mathrm{kg}^{-1} \mathrm{OC}$ \\
\hline Concentration in suspended solids & $C_{O C}^{S S}$ & $\mu \mathrm{g} \times \mathrm{kg}^{-1} \mathrm{OC}$ \\
\hline $\begin{array}{l}\text { Constant ratio between sorption affinities for suspended OC and sedim ent OC } \\
\text { in the relation } \\
\boldsymbol{K}_{\boldsymbol{O C}}^{S S}=\boldsymbol{\gamma} \boldsymbol{K}_{\boldsymbol{O C}}^{S E \boldsymbol{D}}\end{array}$ & $\gamma$ & - \\
\hline Derm al uptake rate constant & $k_{w}$ & $\mathrm{~L} \times \mathrm{kg}^{-1} \times \mathrm{d}^{-1}$ \\
\hline Elim ination rate constant & $k_{e}$ & $\mathrm{~d}^{-1}$ \\
\hline Food ingestion rate & $I$ & 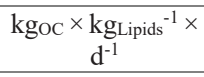 \\
\hline Fraction of ingested $\mathrm{OC}$ originating from the sedim ent & $\begin{array}{c}\beta \\
(0<\beta<1)\end{array}$ & 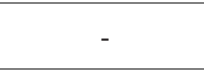 \\
\hline Growth rate constant & $k_{g}$ & $\mathrm{~d}^{-1}$ \\
\hline Lipid water partition coefficient $\left(\boldsymbol{k}_{\boldsymbol{w}} / \boldsymbol{k}_{\boldsymbol{e}}\right)$ & $K_{\text {lip }}$ & $\mathrm{L} \times \mathrm{kg}^{-1}$ \\
\hline Sedim ent water partition coefficient & $K_{O C}^{S E D}$ & $\mathrm{~L} \times \mathrm{kg}^{-1}$ \\
\hline $\begin{array}{l}\text { Species-specific elim ination param eter in the relation } \\
\boldsymbol{L} \operatorname{og} K_{\boldsymbol{e}}=-\boldsymbol{\operatorname { L o g }} \boldsymbol{K}_{\boldsymbol{o w}}+\boldsymbol{a}\end{array}$ & a & - \\
\hline Suspended solids water partition coefficient & $K_{O C}^{S S}$ & $\mathrm{~L} \times \mathrm{kg}^{-1}$ \\
\hline Tim e & $t$ & $\mathrm{~d}$ \\
\hline
\end{tabular}




\section{Chapter 3}

Table S10. Astarte borealis background polycyclic arom atic hydrocarbons (PAHs) concentrations (m ean $\pm \mathrm{SD} ; \mu \mathrm{g} / \mathrm{kg}$ lipid wt.).

\begin{tabular}{lrr}
\hline PAH & $2013^{a}$ & 2014 \\
\hline PHE & $193.52 \pm 169.41$ & $2708.86 \pm 341.85$ \\
\hline ANT & $45.25 \pm 93.27$ & $664.10 \pm 91.68$ \\
\hline FLT & $96.07 \pm 67.43$ & $385.65 \pm 80.61$ \\
\hline PYR & $297.78 \pm 198.32$ & $313.13 \pm 30.09$ \\
\hline BaA & $18.78 \pm 21.82$ & n.a. \\
\hline CHR & $106.90 \pm 74.79$ & $4614.76 \pm 5290.49$ \\
\hline BeP & $96.95 \pm 56.92$ & $245.85 \pm 32.57$ \\
\hline BbF & $58.61 \pm 32.37$ & $62.18 \pm 14.44$ \\
\hline BkF & $34.57 \pm 25.36$ & n.a. \\
\hline BaP & $14.56 \pm 19.59$ & n.a. \\
\hline BghiP & $23.65 \pm 30.32$ & $393.05 \pm 616.28$ \\
\hline dBahA & $13.09 \pm 21.49$ & n.a. \\
\hline Ind123P & $75.70 \pm 68.40$ & $56.89 \pm 39.89$ \\
\hline$\sum{ }_{13}$ PAH & $1075.43 \pm 684.05$ & $9444.47 \pm 6537.91$ \\
\hline
\end{tabular}

${ }^{a}$ Individuals collected in July 2013 by Szczybelski et al. (Chapter 2) belong to size classes 2 to 4 as described by the authors ( 36 to $\geq 40 \mathrm{~m} \mathrm{~m}$ shell length), whereas individuals from 2014 collected by the presenstudy averaged $31.3 \pm 4.63 \mathrm{~m} \mathrm{~m}$ (shell length). Both groups were collected in different sam pling years near Blom strandhalvøya, Kongsfjorden Bay (Svalbard, Norway). n.a.: not available.

Table S11. High treatm ent (BSH) polycyclic arom atic hydrocarbons biotasedim ent accum ulation factors (BSAFs) percentile ranges for Arctic (Astarte borealis, Macoma calcarea and Nuculana pernula) and tem perate (Limecola balthica) bivalves.

\begin{tabular}{|c|c|c|c|c|c|c|c|c|}
\hline \multirow{2}{*}{$\begin{array}{l}\text { Spp. } \\
\text { BSAF percentile }\end{array}$} & \multicolumn{2}{|c|}{ Astarte borealis } & \multicolumn{2}{|c|}{ Macoma calcarea } & \multicolumn{2}{|c|}{ Limecola balthica } & \multicolumn{2}{|c|}{ Nuculana pernula } \\
\hline & 10th & 90th & 10th & 90th & 10th & 90th & 10th & 90th \\
\hline PHE & 0.43 & 1.13 & 0.18 & 0.21 & 0.10 & 0.13 & 0.14 & 0.16 \\
\hline ANT & 0.34 & 0.72 & 0.12 & 0.14 & 0.03 & 0.07 & 0.08 & 0.12 \\
\hline FLT & 0.16 & 0.50 & 0.11 & 0.17 & 0.07 & 0.09 & 0.07 & 0.09 \\
\hline PYR & 0.17 & 0.51 & 0.11 & 0.18 & 0.13 & 0.19 & 0.08 & 0.10 \\
\hline $\mathrm{BaA}$ & 0.03 & 0.08 & 0.04 & 0.07 & 0.13 & 0.15 & 0.09 & 0.10 \\
\hline CHR & 0.13 & 0.88 & 0.06 & 0.08 & 0.31 & 1.67 & 2.57 & 16.64 \\
\hline $\mathrm{BeP}$ & 0.04 & 0.18 & 0.04 & 0.07 & 0.09 & 0.11 & 0.11 & 0.14 \\
\hline $\mathrm{BbF}$ & 0.03 & 0.08 & 0.03 & 0.06 & 0.10 & 0.13 & 0.09 & 0.12 \\
\hline BghiP & 0.04 & 0.36 & 0.01 & 0.12 & 0.23 & 2.36 & 0.83 & 2.94 \\
\hline dBahA & 0.02 & 0.05 & 0.03 & 0.05 & 0.02 & 0.11 & 0.03 & 0.10 \\
\hline Ind123P & 0.02 & 0.04 & 0.02 & 0.03 & 0.03 & 0.08 & 0.06 & 0.08 \\
\hline
\end{tabular}


Chapter 3

Table S12. High treatm ent (PSH) polycyclic arom atic hydrocarbons biotasedim ent accum ulation factors (BSAFs) percentile ranges for Arctic (Nephtys ciliata) and tem perate (Alitta virens) polychaetes.

\begin{tabular}{lcccc}
\hline Spp. & \multicolumn{2}{c}{ Nephtys ciliata } & \multicolumn{2}{c}{ Alitta virens } \\
\hline BSAF percentile & 10th & 90th & 10th & 90th \\
\hline PHE & 0.09 & 0.19 & 0.03 & 0.25 \\
\hline ANT & 0.03 & 0.07 & 0.01 & 0.04 \\
\hline FLT & 0.13 & 0.20 & 0.04 & 0.13 \\
\hline PYR & 0.13 & 0.22 & 0.03 & 0.11 \\
\hline BaA & 0.01 & 0.03 & 0.00 & 0.01 \\
\hline CHR & 0.03 & 1.23 & 0.02 & 0.16 \\
\hline BeP & 0.03 & 0.05 & 0.01 & 0.03 \\
\hline BbF & 0.01 & 0.02 & 0.00 & 0.01 \\
\hline BghiP & 0.13 & 1.70 & 0.01 & 0.10 \\
\hline dBahA & 0.03 & 0.05 & 0.01 & 0.02 \\
\hline Ind123P & 0.01 & 0.03 & 0.00 & 0.01
\end{tabular}

Table S13. Statistical test for differences in lipid-norm alised polycyclic arom atic hydrocarbons concentrations between Arctic species exposed to the high treatm ent (KruskalWallis test $p$-value).

\begin{tabular}{|l|l|l|l|l|l|l|l|}
\hline \multicolumn{1}{|c|}{ Spp. } & PHE & ANT & FLT & PYR & CHR & BeP & BbF \\
\hline Macoma calcarea & & & & & & & \\
\hline Nephtys ciliata & & & & & & & \\
\hline Astarte borealis & 0.110 & 0.046 & 0.088 & 0.080 & & & \\
\hline Nuculana pernula & & & & & 0.091 & 0.075 & 0.054 \\
\hline
\end{tabular}




\section{Chapter 3}

Table S14. Statistical test for differences in lipid-norm alisedpolycyclic arom atic hydrocarbons concentrations between Arctic bivalve species exposed to the high treatm ent (Kruskal Wallis test $p$ value).

\begin{tabular}{|l|c|c|c|c|c|c|}
\hline \multicolumn{1}{|c|}{ Spp. } & PHE & ANT & FLT & PYR & CHR & Ind123P \\
\hline Macoma calcarea & & & & & & \\
\hline Astarte borealis & 0.095 & 0.105 & 0.095 & 0.105 & & \\
\hline Nuculana pernula & & & & & 0.069 & 0.069 \\
\hline
\end{tabular}

Table S15. Statistical test for differences in biota-sedim ent accum ulation factors of polycyclic arom atic hydrocarbons between Arctic species exposed to the high treatm ent (Kruskal Wallis tespvalue).

\begin{tabular}{|l|l|l|l|l|l|l|}
\hline \multicolumn{1}{|c|}{ Spp. } & PHE & ANT & FLT & PYR & CHR & BbF \\
\hline Macoma calcarea & & & & & & \\
\hline Nephtys ciliata & & & & & & \\
\hline Astarte borealis & 0.068 & 0.037 & 0.103 & 0.103 & & \\
\hline Nuculana pernula & & & & & 0.103 & 0.054 \\
\hline
\end{tabular}

Table S16. Statistical test for differences in biota-sedim ent accum ulation factors of polycyclic arom atic hydrocarbons between Arctic bivalve species exposed to the high treatm ent (Kruskal Wallis test $p$-value).

\begin{tabular}{|l|l|l|l|l|l|l|}
\hline \multicolumn{1}{|c|}{ Spp. } & PHE & ANT & FLT & PYR & CHR & Ind123P \\
\hline Macoma calcarea & & & & & & \\
\hline Astarte borealis & 0.069 & 0.069 & 0.107 & 0.107 & & \\
\hline Nuculana pernula & & & & & 0.069 & 0.107 \\
\hline
\end{tabular}


Chapter 3

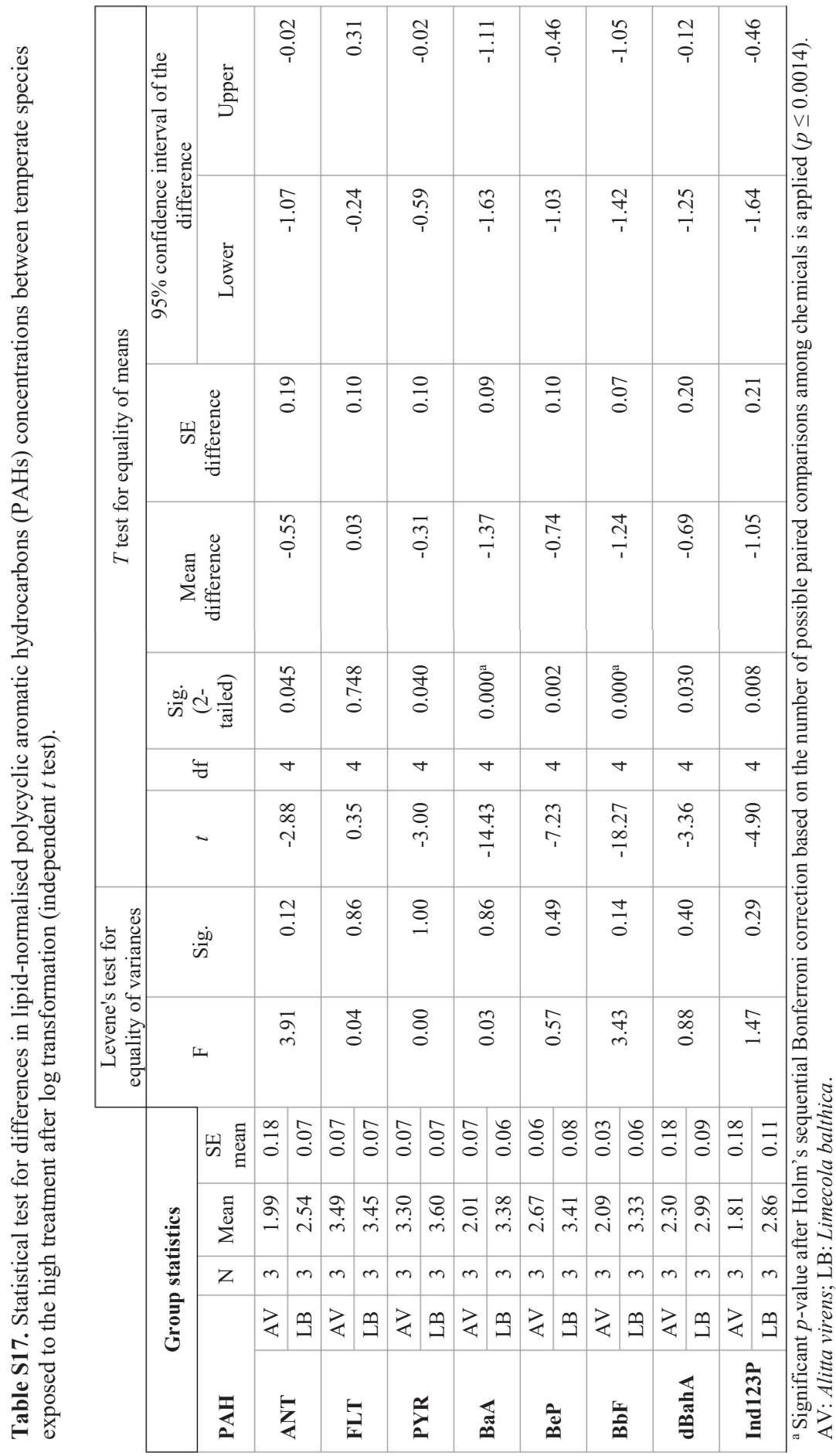




\section{Chapter 3}

Table S18. Statistical test for differences in biota-sedim ent accum ulation factors of polycyclic arom atic hydrocarbons between tem perate species exposed to the high treatm ent (Mann Whitne $U$ test $p$-value).

\begin{tabular}{|l|c|c|c|c|c|c|c|}
\hline \multicolumn{1}{|c|}{ Spp. } & ANT & PYR & BaA & BeP & BbF & dBahA & Ind123P \\
\hline Limecola balthica & 0.050 & 0.050 & 0.050 & 0.050 & 0.050 & 0.050 & 0.050 \\
\hline Alitta virens & & & & & & & \\
\hline
\end{tabular}

Table S19. Statistical test for differences in lipid-norm alised polycyclic arom atic hydrocarbons concentrations between Arctic and tem perate species (Mann Whitney $U$ test $p$-value) based on input data from Tables S5 and S6.

\begin{tabular}{|l|c|c|c|c|c|c|c|c|c|}
\hline \multicolumn{1}{|c|}{ Spp. } & PHE & ANT & BaA & CHR & BeP & BbF & BghiP & dBahA & Ind123P \\
\hline Macoma calcarea & 0.083 & 0.083 & & & & & & & \\
\hline Limecola balthica & & & 0.083 & 0.083 & 0.083 & 0.083 & 0.083 & 0.083 & 0.083 \\
\hline Nephtys ciliata & 0.827 & 0.127 & 0.127 & n.t. & 0.127 & 0.050 & n.t. & n.t. & n.t. \\
\hline Alitta virens & & & & & & & \\
\hline
\end{tabular}

n.t.: not tested.

Table S20. Statistical test for differences in biota-sedim ent accum ulation factors of polycyclic arom atic hydrocarbons between Arctic and tem perate species exposed to the high treatm ent (Mann Whitney $U$ test $p$-value) based on input data from Tables S11 and S12.

\begin{tabular}{|l|c|c|c|c|c|c|c|c|c|c|c|}
\hline \multicolumn{1}{|c|}{ Spp. } & PHE & ANT & FLT & PYR & BaA & CHR & BeP & BbF & BghiP & dBahA & Ind123P \\
\hline Macoma calcarea & 0.083 & 0.083 & 0.083 & & & & & & & & \\
\hline Limecola balthica & & & & 1.000 & 0.083 & 0.083 & 0.083 & 0.083 & 0.083 & 0.248 & 0.083 \\
\hline Nephtys ciliata & 0.827 & 0.127 & 0.050 & 0.050 & 0.050 & n.t. & 0.050 & 0.050 & n.t. & n.t. & n.t. \\
\hline Alitta virens & & & & & & & & n.t. \\
\hline
\end{tabular}

n.t.: not tested. 


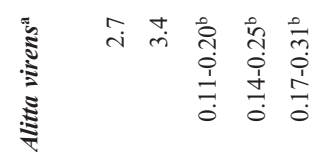

\section{Chapter 3}

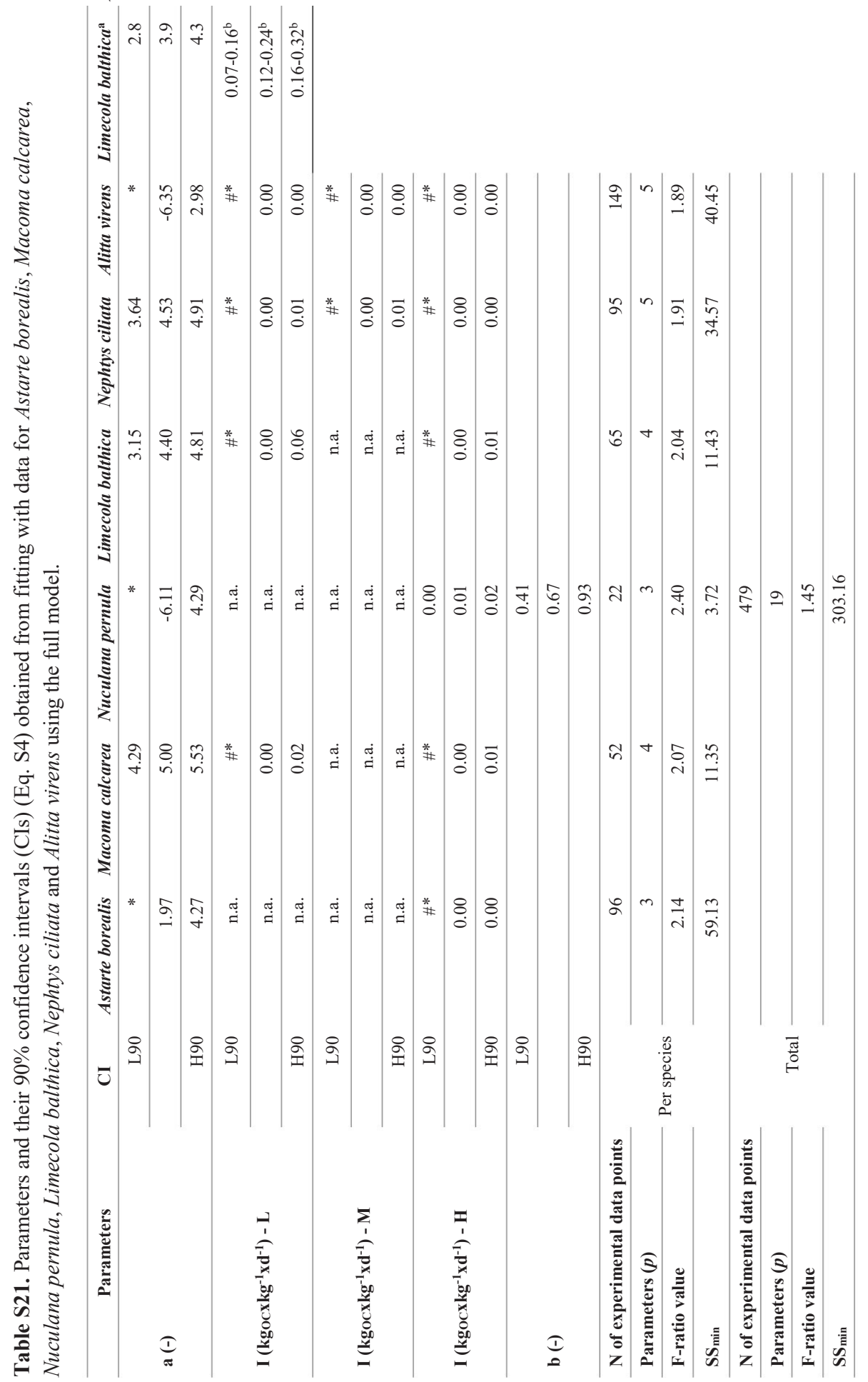

101 


\section{Chapter 3}

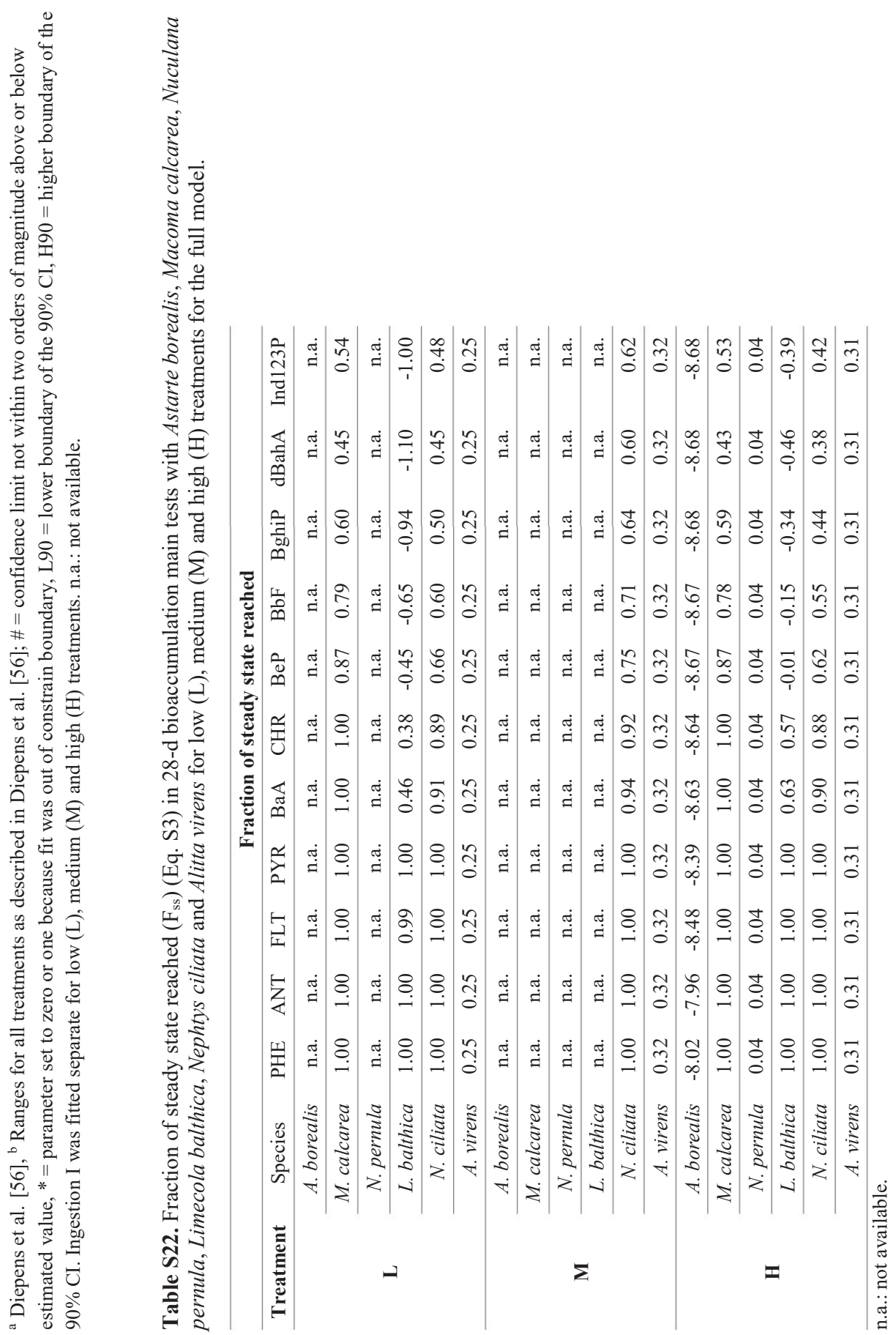




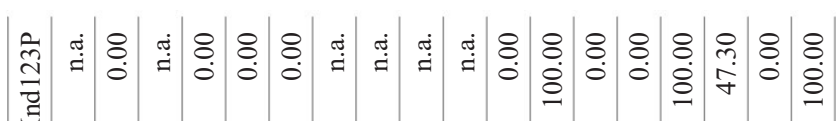

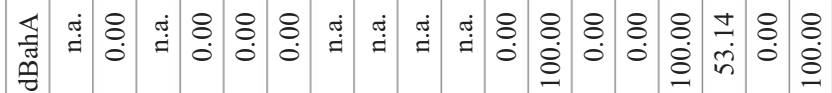

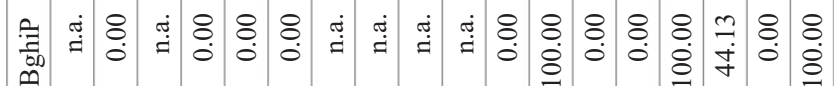
:

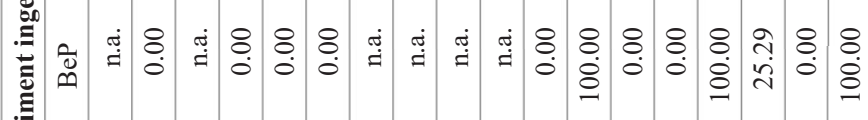

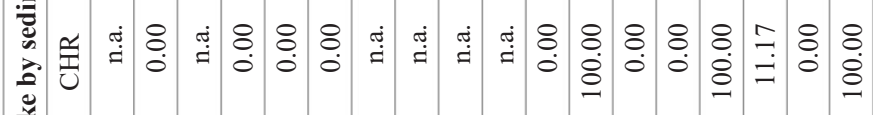
近. 


\section{Chapter 3}
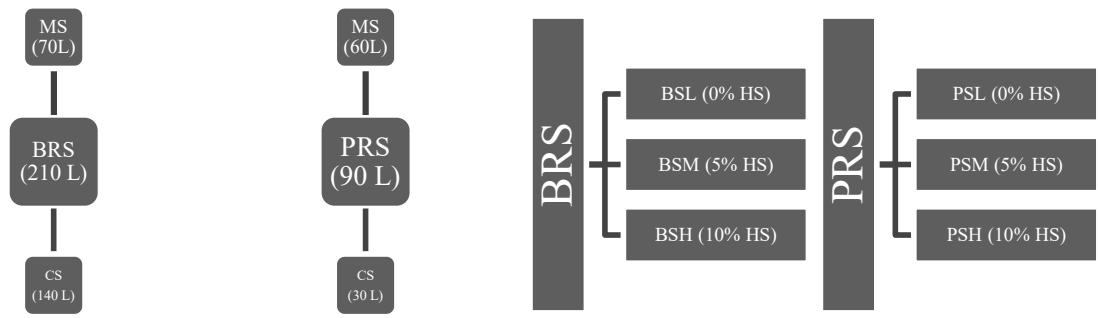

Figure S1. Preparation of Bivalves Reference Sedim ent (BRS) and Polychaetes Reference Sedim ent (PRS) from both m uddy (MS) and coarse (PS) sedim ent.

BRS: Bivalves Reference Sedim ent BSL: Low Bivalves Sedim ent containing background levels of contam inants; BSM: Medium Bivalves Sedim ent containing 5\% (vol.) of harbour sedim ent (HS); BSH: High Bivalves Sedim ent containing 10\% (vol.) of harbour sedim ent (HS); PSL: Low Polychaetes Sedim ert containing background levels of contam inants; PSM: Medium Polychaetes Sedim ent containing 5\% (vol.) of harbour sedim ent (HS); PSH: High Polychaetes Sedim ent containing $10 \%$ (vol.) of harbour sedim ent (HS).
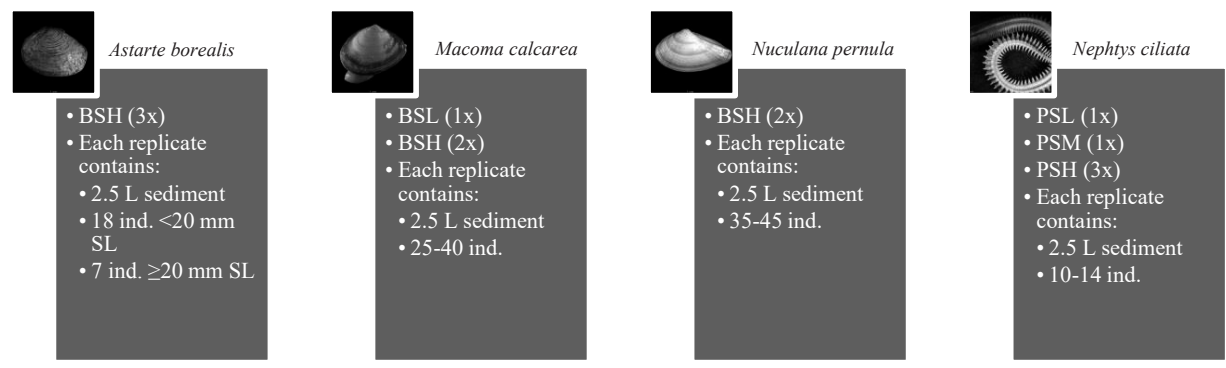

Figure S2. Arctic experim ent (AE) replicates per species and treatm ent.

BSL: Low Bivalves Sedim ent containing background levels of contam inants; BSH: High Bivalves Sedim ent containing 10\% (vol.) of harbour sedim ent; PSL: Low Polychaetes Sedim ent containing background levels of contam inants; PSM: Medium Polychaetes Sedim ent containing 5\% (vol.) of harbour sedim ent; PSH: High Polychaetes Sedim ent containing 10\% (vol.) of harbour sedim ent; SL: shell length; ind.: num ber of individuals. 

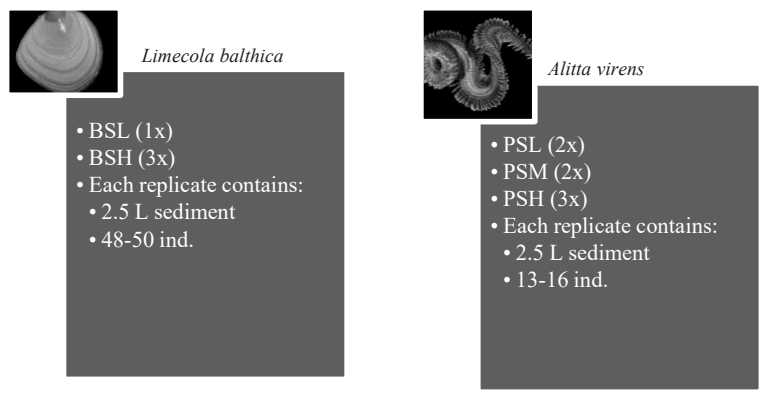

Figure S3. Tem perate experim ent (TE) replicates per species and teatm ent.

BSL: Low Bivalves Sedim ent containing background levels of contam inants; BSH: High Bivalves Sedim ent containing 10\% (vol.) of harbour sedim ent; PSL: Low Polychaetes Sedim ent containing background levels of contam inants; PSM: Medium Polychaetes \$dim ent containing 5\% (vol.) of harbour sedim ent; PSH: High Polychaetes Sedim ent containing 10\% (vol.) of harbour sedim ent; ind.: num ber of individuals.

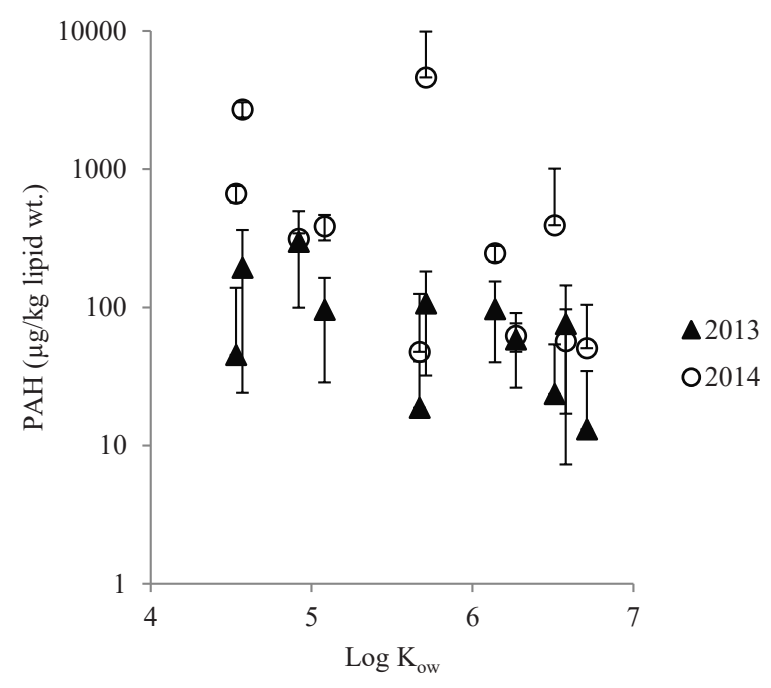

Figure S4. Astarte borealis background polycyclic arom atic hydrocarbons (PAHs) concentrations (m ean $\pm \mathrm{SD} ; \mu \mathrm{g} / \mathrm{kg}$ lipid wt.).

Individuals collected in July 2013 by Szczybelski et al. (Chapter 2) belong to size classes 2 to 4 as described by the authors. Individuals were collected in different sam pling years near Blom strandhalvøya, Kongsfjorden Bay (Svalbad, Norway). 


\section{Chapter 3}
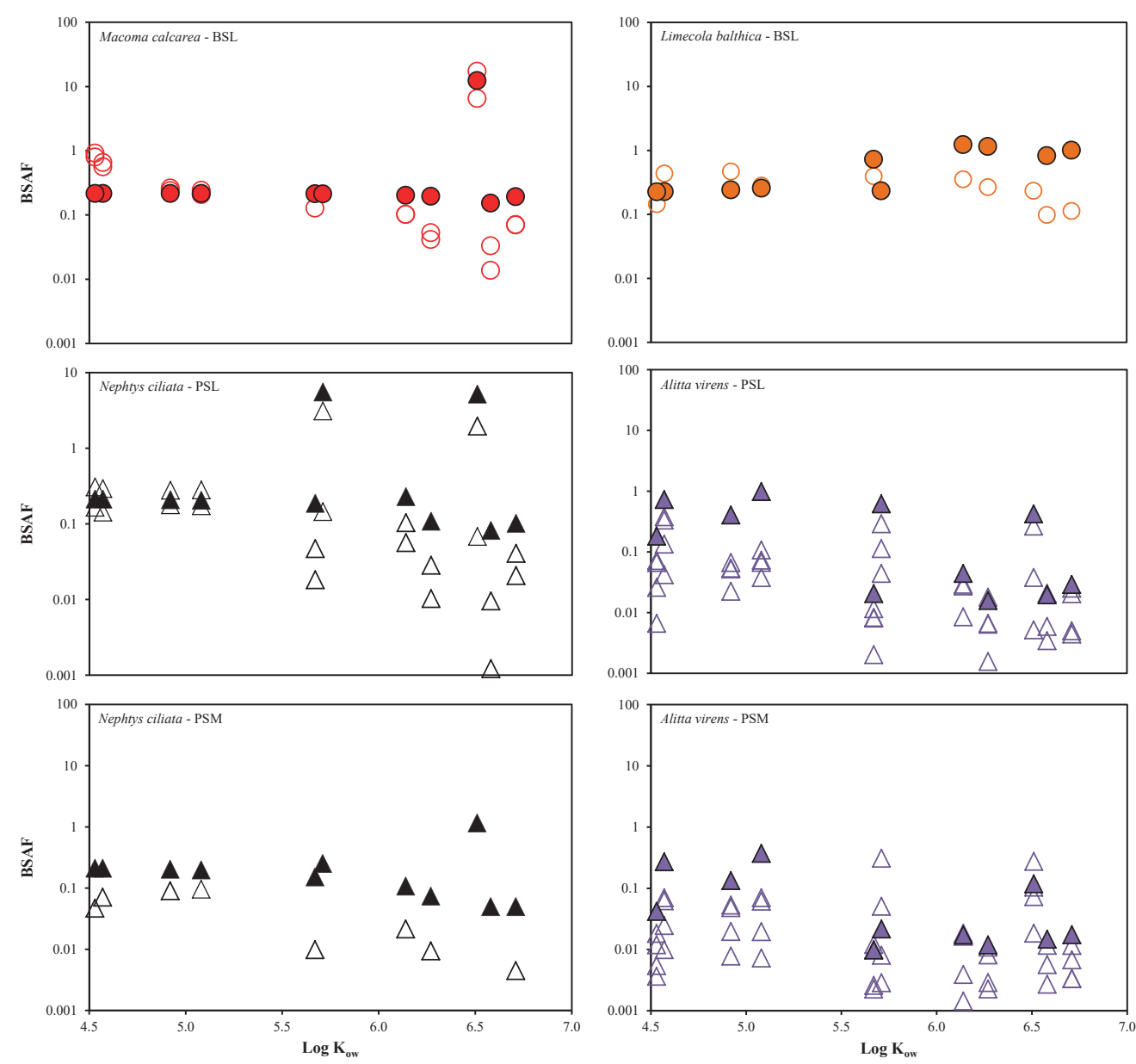

Figure S5. Modelled polycyclic arom atic hydrocarbons biotasedim ent accum ulation factors (BSAFs) (closed sym bols) and actual m easured BSAFs (open sym bols) for Arctick(facoma calcarea and Nephtys ciliata) and tem perate (Limecola balthica and Alitta virens) species exposed to the low (BSL/PSL) and m edium (PSM) treatm ents. 
4 Biomarker responses and biotransformation capacity in Arctic and temperate benthic species exposed to polycyclic aromatic hydrocarbons

Ariadna S. Szczybelski, Martine J. van den Heuvel-Greve, Albert A. Koelm ans \& Nico W. van den Brink

Science of the Total Environment, subm itted 


\title{
Chapter 4
}

\begin{abstract}
Monitoring param eters for the assessm ent of oil and gas related contam inants and their biological effects need validation before application in the Arctic. For such m onitoring purposes, we evaluated the potential use of three biom arkers (acetylcholinesterase, acylCoA oxidase and glutathione S-transferase) for application to an Arctic bivalve (Astarte borealis) and determ ined the body residue of pyrene and two pyrene $m$ etabolites (1-hydroxypyrene and pyrene-1-glucuronide) in Arctic benthic species (bivalve: Macoma calcarea; polychaete: Nephtys ciliata) and tem perate benthic species (bivalve:Limecola balthica; polychaete: Alitta virens) in order to establish the potential of polycyclic arom atic hydrocarbons (PAHs) $\mathrm{m}$ etabolite profiles as biom arkers of exposure in such species. Experim ental PAH exposure levels were probably too low $(0.2-1.7 \mathrm{~m} \mathrm{~g} / \mathrm{kg}$ dry ut. in sedim ent) to induce or inhibit biom arker responses in $A$. borealis. Concentrations of pyrene and pyrene $\mathrm{m}$ etabolites varied between species, although no consistent patterns could be established am ong taxonom ic groups and locations. Metabolites m ade up to $79 \%$ of the total pyrene concentrations indicating that basal $\mathrm{m}$ etabolic activity is affecting pyrene kinetics even at low concentrations in all species. This indicates that Arctic and tem perate species could show sim ilar m etabolism patterns of PAHs, although $\mathrm{m}$ ore insight into the effects of confounding factors is needed.
\end{abstract}




\section{Chapter 4}

\section{Introduction}

Current baseline inform ation on potential effects of oil and gas $(O \& G)$ activities on the Arctic ecosystem or ecosystem com ponents is still inadequate or unavailabl£72], particularly on the cum ulaive effects of O\& Grelated toxic com pounds. More inform ation is neded because the retreat of sea ice in the Arctic will cause an increase in O\& G related activities[14]. Hence, further studies on assessing the vulnerability of Arctic biota to O\& G related chem icals are essential, in order to inform policy and to ensure that $O \& G$ risk assessm ent procedures are targeted to the Arctic environm ent.

Polycyclic arom atic hydrocarbons (PAHs) are the $\mathrm{m}$ ain organic pollutants related to O\& $\mathrm{G}$ activities, which have been identified as an em erging concern in the Arctic[121]. Once released into the $\mathrm{m}$ arine environm ent, partitioning of PAHs to settling particulate organic $m$ atter generally results in contam ination of sedim ents and chronic exposure fobenthic organism s. Accum ulation of PAHs by benthic organism s depends on several factors such as the species' feeding behavior, physiological responses to PAH exposure like detoxification and excretion of PAHs [256], as well as sedim ent characteristics [80]. Biological responses (biom arkers) to exposure to PAHs $\mathrm{m}$ ay be used asindicators of exposure to or sublethal ecological effects of $\mathrm{O} \& \mathrm{G}$ related activities, and the use of such biom arkers $\mathrm{m}$ ay provide an early warning for hazard [257] and ecological risk assessm ent[86,258].

Studies have docum ented effects of oil at the cellular, individual and com m unity level in Arctic benthic com m unities $104,122,259,260]$, but they provide little inform ation on the specific chem icals in the com plex oil $\mathrm{m}$ atrix causing the effects. Although PAHs are the $\mathrm{m}$ ajor group of organic contam inants in oil, there is alarge knowledge gap on their specific role in affecting the responsiveness of biochem ical biom arkers in Arctic benthos chronically exposed to O\& G derived chem icals[261]. Furtherm ore, alm ost no inform ation on PAH m etabolites in benthic invertebrates is available that $\mathrm{m}$ ay be used to assess oilderived hazards and risks for Arctic benthic organism s[213]. In order to address these knowledge gaps the aim sof the present study were to (1) identify the responsiveness of biochem ical biom arkers of exposure and effects in Arctic benthic species, and to (2) assess the use of profiles of $m$ etabolites of a m odel PAH (i.e., pyrene) for m onitoring of exposure and effcts in Arctic benthic invertebrates. This was perform ed experim entally, using representative species of the Arctic $\mathrm{m}$ acrobenthic com $\mathrm{m}$ unity (the suspension feedeAstarte borealis [Schum acher, 1817], the suspension/deposit feeder Macoma calcarea [Gm elin, 1791] and the predator/deposit feeder 


\section{Chapter 4}

Nephtys ciliata [O.F. Müller, 1776]), which are com pared to tem perate counterpart species (the suspension/deposit feeder Limecola balthica [Linnaeus, 1758] and the om nivore/deposit feeder Alitta virens [Sars, 1835], formerly known as Macoma balthica and Nereis virens, respectively).

Selected biom arkers of exposure were the peroxisom a/ $\beta$-oxidation enzym e acylCoA oxidase (AOX, E.C.1.3.3.6) and Phase II biotransform ation enzym e glutathione Stransferase (GST, E.C.2.5.1.18). The biom arker of neurotoxicity consisted of acetylcholinesterase (AChE, E.C.3.1.1.7). These were determ ined inA. borealis, upon exposure to PAH-contam inated sedim ent under laboratory conditions. In a second experim ent, selected pyrene $\mathrm{m}$ etabolites $(-1$ hydroxypyrene [OHPyr, Phase I m etabolite, Figure 1] and pyrene-1-glucuronide [GluPyr, Phase II m etabolite, Figure 1]) were analyzed in Arctic (M. calcarea, N. ciliata) and tem perate (L. balthica, A. virens) bivalves and polychaetes exposed to PAH-contam inated sedim ent under laboratory conditions. Due to lim ited availability of test anim als it was not feasible to analyze biochem ical biom arkers and $m$ etabolite profiles in the sam e experim ents. In the first experim ent, an Arctic species was selected for which am ple inform ation was available on biom arker responses in sim ilar tem perate species. As for $\mathrm{m}$ etabolite profiles, $\mathrm{m}$ uch lessinform ation is available, so we conducted a broader experim ental approach, com paring species with different feeding m odes and geographical origin. 


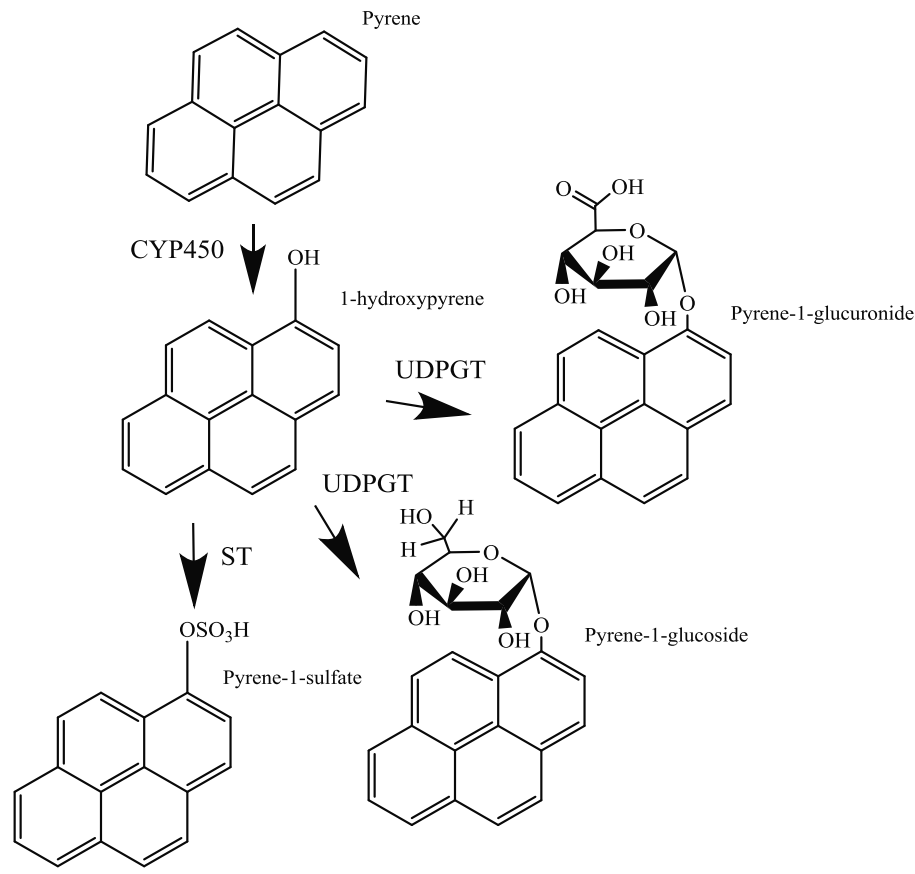

Figure 1. Biotransform ation pathway for pyrene inAlitta virens (adapted from Jørgensen et al. [183]). CYP450: cytochrom e P450 enzym es; ST: sulfotransferase enzym es; UDPGT: glucuronosyltransferase enzym es.CYP450 form s Phase I m etbolites, whereas ST and UDPGT form Phase II $m$ etabolites.

\section{Materials and Methods}

\subsection{Test organisms}

Based on their feeding habits, sessility and relative abundance in Kongsfjorden Bay (Svalbard, Norway), three Arctic benthic species were selected: the suspension feeder $A$. borealis, the suspension/deposit feeder M. calcarea, and the carnivore/om nivoreN. ciliata. Additionally, two counterpart tem perate species (thesuspension/deposit feeder L. balthica and the deposit feeder/om nivore $A$. virens) were selected based on their com parable habitat and feeding traits with Arctic species. Perm ission for sam pling of Arctic and tem perateL. balthica) species was issued by The Governor of Svalbard and the Province of Zeeland, respectively. A. virens was obtained from a professional bait farm, Topsy baits 


\section{Chapter 4}

(Wilhelm inadorp, the Netherlands). For details of the sam pling and acclim atization of test species and sedim ent collection, the reader is referredto the Supporting Inform ation (SI)

\subsection{Sediment treatments preparation}

Reference sedim ent was collected in the Oosterschelde estuary (The Netherland, 51 ${ }^{\circ} 36^{\prime} 13^{\prime \prime} \mathrm{N}$, $3^{\circ} 47^{\prime} 49$ "E) on 24 to 25 April 2014 and 2 May 2014, and naturally contam inated sedim ent was collected near Nesserdijk (Rotterdam, the Netherlands, 51 54'14"N, 4³1'17"E) by Nautisch Service Centrum in April 2014. Two different batches of reference sedim ent were prepared to ensure an optim al habitat for the test species. Since the bivalve species (A. borealis, $M$. calcarea and L. balthica) usually reside in sandy sediment, their sedim ent batch consisted of two thirds of coarse and one third of m uddy sedim ent, based on volum eN. ciliata and $A$. virens are generally found in sandy $\mathrm{m}$ ud, so a sedim ent batch consisting of two thirds of m uddy and one third of coarse sedim entwas prepared for these species.

The reference sediments are referred to as the 'low' (L) treatm ent: BSL (Bivalve Sedim ent Low for bivalves) and PSL (Polychaete Sedim ent Low for polychaetes). Two additional sedim ent treatm ents were prepared with a higher an ount of harbour sedim ent increasing the chemical concentrations, referred to as 'medium' (BSM and PSM with 5\% harbour sedim ent) and 'high' (BSH and PSH with 10\% harbour sedim ent) treatm ents. These preparations thus resulted in six sedim ents: three for bivalves (BSL, BSM, BSH) and three for polychaetes (PSL, PSM, PSH) (Tables S5 and S6).

All sedim ent treatm ents were thoroughly $m$ ixed before storage and transport from the Netherlands to Svalbard, before use in the exposure experim ents. Due to logistics, storage tim e (at $3-7{ }^{\circ} \mathrm{C}$ ) for sedim ent treatm ents was 8 and 17 weeks in the tem perate and Arctic experim ent, respectively. Prior to the start of exposure, sedim ent was allowed to settle in contact with filtered sea water in a 1:6 sedim entto-water volum e rati without aeration during $3 \mathrm{~d}$ and with aeration during the following $4 \mathrm{~d}$. In the Arctic experim ent som e aquaria were aerated for 7 to $14 \mathrm{~d}$ because biota field sam pling took longer than initially expected.

$\Sigma_{13} \mathrm{PAH}$ concentrations in the high $(\mathrm{H})$ treatm ent were selected to be above or within average sedim ent $\Sigma_{16} \mathrm{PAH}$ concentration detected in Arctic oil-im pacted areas like Ny-Ålesund harbour (Svalbard, Norway) [149], and Gulf of Alaska (USA) after 4 and 13 years of the Exxon Valdez oil spill [262] (Table 1). 
Table 1. Total polycyclic arom atic hydrocarbons (PAHs) concentrations ( $\mathrm{m}$ in-m ax; $\mu \mathrm{g} / \mathrm{kg}$ dry wt.) in sedim ent and biota (soft tissue) available in the literature.

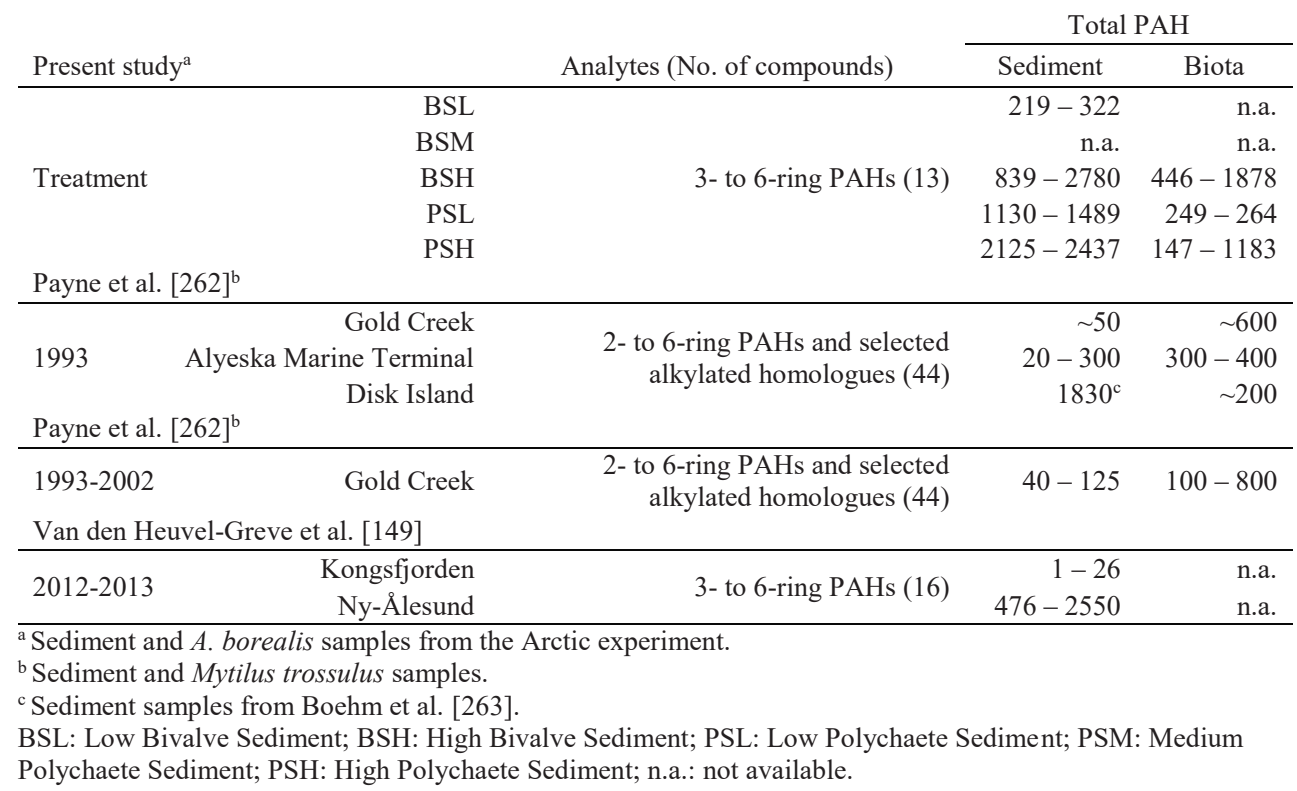

\subsection{Experimental design}

Two 28-d exposure experim ents were conducted: a first with Arctic species and conditions at Kings Bay AS (Ny-Ålesund, Svalbard) (Septem ber toOctober 2014); and another with tem perate species and conditions at Wageningen Marine Research (Yerseke, the Netherlands) (July to August 2014). The Arctic experim ent was perform ed in a tem perature controlled room $\left(3 \pm 1{ }^{\circ} \mathrm{C}\right)$ with a photoperiod of $12 \mathrm{~h}$ light $12 \mathrm{~h}$ dark, whereas the tem perate experim ent was perform ed in a tem perature controlled room $\left(18 \pm 1^{\circ} \mathrm{C}\right)$ with a photoperiod of $18 \mathrm{~h}$ light: 6 h dark.

Exposure treatm ents were achieved in quadruplicate or $\mathrm{m}$ ore forA. borealis (BSL, BSM and $\mathrm{BSH}$ ), whereas for the rest of the test species, these were achieved in duplicate or $\mathrm{m}$ ore due to low availability of test organism s (Table S1).For A. borealis, each aquarium contained 25 individuals of which 18 individuals were classified as 'small' $(<2 \mathrm{~cm})$ and 7 individuals were classified as 'large' ( $2-4 \mathrm{~cm}$ ), based on shell length. ForM. calcarea, L. balthica, N. ciliata and $A$. virens, each aquarium contained 40to 50, 50, 20 and 16 individuals, respectively (Table S1). Individuals were not fed during exposure. 


\section{Chapter 4}

No m orality was observed for any species in any treatm ent. At the end of the experim ents, organism s were allowed to depurate their guts for $24 \mathrm{~h}$ in filtered seawater. Anim als were weighed, m easured for body or shell length, dissected (e.g., bivalves), snap-frozen and stored at $-80^{\circ} \mathrm{C}$ for the determ ination of enzym atic activities inA. borealis sam ples or at $-20^{\circ} \mathrm{C}$ for the analysis of pyrene and pyrene m etabolites in Arctic (M. calcarea, N. ciliata) and tem perate (L. balthica, A. virens) species.

A. borealis samples were shipped in a dry-shipper in liquid nitrogen (Arctic Express 20, Therm o Fisher Scientific) to Plentzia Marine Station (University of the Basque Country) at Plentzia (Biscay, Spain), while the rem aining sam ples were shipped in dryice to the Departm ent of Analytical Chem istry (University of the Basque Country) at Leioa (Biscay, Spain).

\subsection{Chemicals}

2',7'-dichlorofluorescin diacetate (DCF), N,N-dim ethylform am ide (DMF), palm itoyl coenzym e A lithium salt, peroxidase from horseradish, sodium azide, iton ${ }^{\mathrm{TM}} \mathrm{X}-100$ and ethylenediam inetetraacetic acid disodium salt dihydrate (EDTAN $\left.{ }_{2}\right)($ Sigm aAldrich) were used for the determ ination of AOX activity. Butylated hydroxytoluene (BHT), acetylthiocholine iodide (ATC), 5,5'-dithiobis(2-nitrobenzoic acid) (DTNB) (Sigm aAldrich) and sodium bicarbonate (VWR) were used for the determ ination of AChE activity. 1chloro2,4-dinitrobenzene (CDNB) and L-glutathione reduced (GSH) (Sigm aAldrich) were used for the determination of GST activity. Quick Start ${ }^{\mathrm{TM}}$ Bradford Kit 4 (Bio-Rad) was used for protein determ ination.

Pyrene (98\%), 1-hydroxypyrene (98\%) (Sigm aAldrich), pyrenyl-1-O-glucuronide (98.2\%) (Isostandards Material), acetone, $\mathrm{m}$ ethanol, acetonitrile (HPLC grade) (Macrom Fine Chem icals), $0.45 \mu \mathrm{m}$ polyam ide filters (Machrey-Nagel) and Oasis HLB (200 m g) cartridges (Waters) were used for the determ ination of pyrene $m$ etabolites.

\subsection{Enzymatic activities}

Pooled digestive glands of either 9 'small' or 3 'large' A. borealis individuals were hom ogenized in 1:5 volum es of $100 \mathrm{~m}$ M potassium phosphate buffer ( $\mathrm{pH}$ 7.4) in a tissue hom ogenizer (Precellys ${ }^{\circledR} 24$, Bertin Technobgies) at $6,000 \mathrm{rpm} \times 30 \mathrm{~s}\left(5^{\circ} \mathrm{C}\right)$. Hom ogenates for AOX determ ination were obtained after a centrifugation of the hom ogenate at $500 \mathrm{~g} \mathrm{x} 15$ 
$\mathrm{m}$ in $\left(4^{\circ} \mathrm{C}\right)\left(\right.$ Allegra ${ }^{\circledR} 25 \mathrm{R}$ Benchtop Centrifuge, Beckm an Coulter). $100 \mu \mathrm{L}$ of supernatant was used for AOX determ ination whereas the rem aining volum e was centrifuged at 13,280 $\times 20 \mathrm{~m}$ in $\left(4^{\circ} \mathrm{C}\right)$ (Microfuge ${ }^{\circledR}$ 22R Microcentrifuge, Beckm an Coulter) to obtain the post $\mathrm{m}$ itochondrial fraction(S12) in the supernatant for further biochem ical determ inations of AChE and GST activities. Sam ples were stored at $-80{ }^{\circ} \mathrm{C}$ if not directly used. All assays were carried out in quadruplicate per sam ple at $22^{\circ} \mathrm{C}$ (AChE, GST) or in duplicate at $25^{\circ} \mathrm{C}$ (AOX).

AOX activity was analyzed in A. borealis 1:4 $500 \mathrm{~g}$ hom ogenates followingSm all et al.[264]. AChE activity was analyzed in A. borealis $\mathrm{S} 12$ hom ogenates followingGuilherm ino et al. [265]. GST activity was analyzed in S12 hom ogenates followingHabig et al. [266] with som e $\mathrm{m}$ odifications (i.e., reaction $\mathrm{m}$ edium is $00 \mathrm{~m} \mathrm{M}$ potassium phosphate buffer $\mathrm{pH}$ 7.4)AChE and GST activity rates were recorded in 96-well Sterilin ${ }^{\mathrm{TM}}$ Clear Microtiter ${ }^{\mathrm{TM}}$ plates (Thermo Fisher Scientific) at 412 and $340 \mathrm{~nm}$ every $60 \mathrm{~s}$ during 5 and $3 \mathrm{~m}$ in, respectively (PowerWave HT Microplate Spectrophotom eter, BioTek). Total cytosolic protein was m easured in the sam e hom ogenate fraction where enzym atic activities were analyzed followingowry et al. [267]

\subsection{Pyrene metabolites}

Sam ples were frozen and freezedried prior to the extraction step. Each sam ple was weighed and extracted in $10 \mathrm{~m} \mathrm{~L}$ of acetone in a $40 \mathrm{~m} \mathrm{~L}$ polypropylene vessel. Focused ultrasound solie liquid extraction (FUSLE) was perform ed in the pulsed mode for $2 \mathrm{~m}$ in, with a pulsed tim e 'on' of $0.8 \mathrm{~s}$ and pulsed time 'off' of $0.2 \mathrm{~s}$, at $20 \%$ of irradiation power [268]. Extractions were perform ed at $0{ }^{\circ} \mathrm{C}$ in an icewater bath [269]. After the extraction step, the supernatant was filtered through $0.45 \mu \mathrm{m}$ poliam ide filters and evaporated to $500 \mu \mathrm{L}$ under a nitrogen stream at $35^{\circ} \mathrm{Cusing}$ a Turbovap LV evaporator (Zym ark).

200-m g Oasis HLB cartridges were conditioned with $10 \mathrm{~m} \mathrm{~L}$ of MilliQ:acetonitrile (1:9, v/v). Then, the sam ple was loaded and $1 \mathrm{~m} \mathrm{~L}$ of MilliQ water was added and cartridges were dried for an hour under vacuum. Then, the analytes were eluted using $10 \mathrm{~m} \mathrm{~L}$ of acetonitrile and collected in a test tube. The eluate was evaporated until dryness under a gentle stream of nitrogen at $35{ }^{\circ} \mathrm{C}$ and reconstituted in $150 \mu \mathrm{L}$ of $\mathrm{m}$ ethanol. Finally, the analyses of pyrene $\mathrm{m}$ etabolites wereperform ed by highperform ance liquid chrom atograph with fluorescence detector (HPLC-FLD). For further details on the extraction, clean-up and instrum ental analysis see the SI. 


\section{Chapter 4}

\subsection{Data analyses}

Data were checked for norm ality with QQ plots and the Shapiro-Wilk test and for equality of variances with Levene's test. Differences among treatment groups were assessed either by one-way ANOVA and Tukey HSD as a post-hoc test in case of norm ally distributed data, or by the Kruskal-Wallis non-param etric rank testfor each of the biom arkers inA. borealis. For each taxonom ic group (i.e., bivalves and polychaetes), differences in the content ofGluPyr am ong $\mathrm{L}$ and $\mathrm{H}$ treatm ent groups and am ong clim atic groups were analyzed by either ANCOVA, or m ultiple linear regressin, respectively. For the ANCOVA test the content of pyrene (Pyr) was used as the covariate and for $\mathrm{m}$ ultiple linear regression the treatm ent group and source region of the species were used as predictors. A sim ple linear regression between Pyr and GluPyr concentration was also calculated for each of the species. The sim ple linear regression was used to analyze any likely difference in GluPyr/Pyr ratios am ong species. Significance level of an overall statistical com parison was set at $p \leq 0.05$, while for pairwise com parisons a Bonferroni correction was applied.All statistical calculations were perform ed using SPSS version 22.

\section{Results and Discussion}

\subsection{Enzymatic activities}

Exposure to the selected $\Sigma_{13}$ PAH concentration range (i.e., $287-1710 \mu \mathrm{g} / \mathrm{kg}$ dry wt. sedim ent; Table S5) had no significant effect on any biom arker response inA. borealis digestive gland (Tables 2, S11-S13). Nevertheless, AChE activity in BSH exposed A. borealis was relatively low and within the range as detected in m ussels from either hitorically polluted areas [270] or transplanted to harbour areas [271], indicating a potential neurotoxic response. Exam ples of classical AChE inhibitors are organophosphate and carbam ate pesticides, although PAHs m ay also show AChE inhibition capacity[270,272]. However, low $\mathrm{AChE}$ activity could also be due to either a low AChE substrate specificity in digestive gland with respect to gills as observed in scallops [273] or a stressed physiological status in $A$. borealis as observed in caged $\mathrm{m}$ ussels[274].

The absence of AChE inhibition in A. borealis is also in line with the lack of GST and AOX induction (Table 2). GST activity in A. borealis was below baseline levels as detected in digestive gland of scallops (Chlamys islandica) [215,275] and slightly lower than those in 
m ussels (Mytilus galloprovincialis) experim entally exposed to sim ilar PAH concentrations (Table 3; [276]). GST activity is m ainly correlated to the concentration of 5- to 6-ring PAHs in m ussels[277]. Yet, higher concentrations of high-m obcular-weight PAHs in BSH exposed A. borealis com pared to sedim entPAH exposed M. galloprovincialis yielded lower GST activity values in $A$. borealis than in $\mathrm{m}$ ussels[276]. Furtherm ore, a negative correlation was observed between GST activity rates in M. galloprovincialis and sedim ent PAH exposure (Table 3; [276]). This indicates that even if lower-m olecularweight PAHs such as phenanthrene, anthracene, fluoranthene and pyrene were $\mathrm{m}$ ainly accum ulated byA. borealis during BSH exposure (Chapter 3), pointing to an absence of GST induction, likely confounding factors such as the nutritional and reproductive state of $A$. borealis could have masked the bivalves' response to organic pollution [278].

Table 2. Acyl-CoA oxidase, acetylcholinesterase and glutathione S-transferase activities $(\mathrm{m}$ ean $\pm \mathrm{SD})$ inAstarte borealis digestive gland.

\begin{tabular}{lcccc} 
Treatm ent & EA $(n)$ & AOX & AChE & GST \\
\hline BSL & 4 & $2.1 \pm 0.4$ & $27.9 \pm 8.4$ & $49.8 \pm 13.4$ \\
BSM & 4 & $2.0 \pm 0.4$ & $35.5 \pm 4.2$ & $47.8 \pm 14.2$ \\
BSH & 6 & $2.3 \pm 0.6$ & $30.7 \pm 14.4$ & $46.7 \pm 11.2$
\end{tabular}

EA: experim ental aquarium; AOX: Acy/CoA oxidase (m U AOX/m g prot.); AChE: Acetylcholinesterase ( $\mathrm{nm} \mathrm{ol} / \mathrm{m}$ in/m g prot.); GST: Glutathione \$ransferase ( $\mathrm{nm} \mathrm{ol} / \mathrm{m} \mathrm{in} / \mathrm{m}$ g prot.)Additional abbreviations are defined in Table 1 .

AOX activity in all $A$. borealis pooled sam ples was above levels as detected in digestive gland of $m$ ussels from or transplanted to harbour areas 279$]$ and at $O \& G$ produced water discharge points [280]. This indicates that AOX levels in the present study were high, even in the controls (i.e., BSL exposed $A$. borealis). Relatively high AOX activity in $A$. borealis $\mathrm{m}$ ay be related to non-toxic factors like low food availability or changing $\mathrm{m}$ etabolic status under post bloom conditions[134]. Although AOX induction has been described as a rapid and reversible response to PAH and PCB exposure [279,281], this process can also be affected by seasonal changes [281]. AOX activity in m ussels (M. galloprovincialis) is usually induced during late winter and spring while AOX levels are negatively correlated with lipid content in digestive tubules of $\mathrm{m}$ ussels during phytoplankton bloom \$282]. AOX $\mathrm{m}$ ay be further induced in $A$. borealis due to the increased synthesis of prostaglandins during the species spawning in early autum $n[282,283]$. Hence, nutritional and reproductive status im pacts on peroxisom e proliferation should be considered as likely confounding factors when interpreting AOX as a biom arker for exposure to environm ental contammints [281]. 


\section{Chapter 4}

Table 3. Total polycyclic arom atic hydrocarbon (PAH) concentrations in whole body soft tissue and glutathione S-transferase activity in digestive gland of exposed bivalve species.

\begin{tabular}{|c|c|c|c|c|}
\hline \multirow[b]{2}{*}{ Source } & \multirow[b]{2}{*}{$\begin{array}{c}\text { Species } \\
\text { (type of exposure) }\end{array}$} & \multicolumn{2}{|c|}{ Total PAH } & \multirow[b]{2}{*}{ GST } \\
\hline & & $\begin{array}{l}\text { Analytes } \\
\text { (No. of } \\
\text { com pounds) }\end{array}$ & $\begin{array}{l}\text { Whole body } \\
\text { soft tissue } \\
\text { (weight units) }\end{array}$ & \\
\hline Present study & $\begin{array}{l}\text { Astarte borealis a } \\
\text { (sedim ent) }\end{array}$ & $\begin{array}{r}\text { 3- to 6-ring PAHs } \\
\text { (13) }\end{array}$ & $\begin{array}{r}170 \text { (wet wt.) } \\
34830 \text { (lipid wt.) }\end{array}$ & $34-62$ \\
\hline \multirow{2}{*}{$\begin{array}{l}\text { Baussant et al. } \\
{[275]}\end{array}$} & $\begin{array}{l}\text { Chlamys islandica } \\
\text { (dispersed oil) }\end{array}$ & \multirow{2}{*}{$\begin{array}{r}\text { 2- to 6-ring PAHs } \\
(16)\end{array}$} & $\begin{array}{l}0 \text { (wet wt.) } \\
6 \text { (wet wt.) } \\
8 \text { (wet wt.) }\end{array}$ & $\begin{array}{l}475 \\
355 \\
425\end{array}$ \\
\hline & $\begin{array}{l}\text { Mytilus edulis } \\
\text { (dispersed oil) }\end{array}$ & & $\begin{array}{r}0 \text { (wet wt.) } \\
3 \text { (wet wt.) } \\
10 \text { (wet wt.) }\end{array}$ & $\begin{array}{l}71 \\
62 \\
85 \\
\end{array}$ \\
\hline \multirow{2}{*}{$\begin{array}{l}\text { Nahrgang et al. } \\
{[215]}\end{array}$} & $\begin{array}{l}\text { Chlamys islandica }{ }^{\mathrm{b}} \\
\text { (bakground) }\end{array}$ & \multirow{2}{*}{$\begin{array}{r}\text { 2- to 6-ring PAHs } \\
\text { (16) }\end{array}$} & $<5-5.7$ (wet wt.) & $500-800$ \\
\hline & $\begin{array}{l}\text { Mytilus edulis } \\
\text { (background) }\end{array}$ & & $5.7-6.3$ (wet wt.) & $0-100$ \\
\hline $\begin{array}{l}\text { Giuliani et al. } \\
\text { [276] }\end{array}$ & $\begin{array}{l}\text { Mytilus } \\
\text { galloprovincialis } \\
\text { (sedim ent) }\end{array}$ & $\begin{array}{r}\text { 2- to 6-ring PAHs } \\
\text { (15) }\end{array}$ & $\begin{array}{l}140 \text { (dry wt.) } \\
300 \text { (dry wt.) } \\
600 \text { (dry wt.) }\end{array}$ & $\begin{array}{r}120 \\
110 \\
90\end{array}$ \\
\hline
\end{tabular}

${ }^{\mathrm{a}}$ A. borealis exposed to BSH treatm ent.

${ }^{\mathrm{b}}$ Biota sam ples collected from the field in Septem ber 2010.

Whole body soft tissue $(\mu \mathrm{g} / \mathrm{kg})$; GST: Glutathione S-transferase ( $\mathrm{nm} \mathrm{ol} / \mathrm{m} \mathrm{in} / \mathrm{m}$ g prot.).

In sum $\mathrm{m}$ ary, we observed a general lack of dose relatd responses of the selected biom arkers in digestive gland of $A$. borealis. This $\mathrm{m}$ ay indicate that exposure levels were too low to induce such changes. However, within treatm ent variation in catalytic activity was rather large, which prevented a sensitive analysis of dose response relationships, but for which knowledge of possible confounding factors was lacking. Therefore, in order to interpret variation in biom arker responses in Arctic m arine invertebrates, relevant confounding param eters should be identifed such as tim e scales for enzym atic induction, conditions of the assays, and $\mathrm{m}$ aturation and nutritional status for field individuals.

\subsection{Pyrene metabolites}

Biotransform ation and excretion of hydrophobic organic pollutants is m ostly m ediated by CYP enzymes, although biotransform ation capacity $\mathrm{m}$ ay be low in $\mathrm{m}$ arine invertebrate\$284]. Only a few studies showed the existence of the aryl hydrocarbon receptor (AHR) transcription factor in $\mathrm{m}$ arine invertebrates and suggested that the expression of Phase I enzymes through AHR in response to hydrocarbon exposure $m$ ight be tissuespecific in bivalves $[285,286]$. Additionally, relatively large differences in dom inating Phase II biotransform ation pathways between invertebrates could yield different PAH m etabolite patterns. In the present study, GluPyr was selected as the $\mathrm{m}$ ajor Phase II $\mathrm{m}$ etabolite because glucuronosyltransferases 
(UDPGTs) have a higher activity rate than sulfotransferases (STs), and also glucuronidation is the $\mathrm{m}$ an conjugation pathway in $A$. virens (Figure 1). In the following subsections, pyrene $\mathrm{m}$ etabolites results are discussed based on the possibilities and lim itations for an interspecies com parison inherent in our selection of $m$ etabolites.

\subsubsection{Pyrene hydroxylation}

OHPyr concentrations were often below the lim it of detection am ong all analyzed individuals (Tables 4, S9 and S10). This agrees with typically low OHPyr/Pyr ratios found in other freshwater [287] and $m$ arine worm $\$ 183,233]$, as well as in $m$ arine clam \$288] due to generally high Phase II biotransform ation levels and/or low induction capacity of Phase I biotransform ation pathways in polychaetes and bivalves. Based on the speciesspecific sedim ent hreshold for $A$. virens (i.e., $10 \mu \mathrm{g}$ pyrene/g dry wt. [183]), an absence of pyrene hydroxylase induction and therefore low OHPyr concentrations, would be expected in $A$. virens exposed to PSH (i.e., $0.5 \mu \mathrm{g}$ pyrene/g dry wt.). This is also expected in L. balthica since its PAH biotransform ation capacity is generally lower than A. virens [139].

\subsubsection{1-hydroxypyrene glucuronidation}

A significant effect of the high treatm ent (PSH) com pared to the low sedim ent treatm ent (PSL) was observed on the concentration of GluPyr in polychaetes ( $p=0.005$, Table S14). This was not detected between BSH and BSL exposed bivalves (Table S15). Sim ilarly, a $\mathrm{m}$ ultiple linear regression on the concentration of GluPyr did generate a significant $\mathrm{m}$ odel for polychaetes when both treatm ent and clim atic groups were included as predictors $R^{2}=0.466$, $p<0.001$, Table S16). This was not the case for bivalves (Table S17).

\subsubsection{Biotransformation of pyrene among climatic groups}

For polychaetes and bivalves different GluPyr/Pyr ratios were observed when com paring Arctic and tem perate species (Figures 2 and 3). GluPyr concentrations in the ArcticN. ciliata were on average twice as high as in the tem perate $A$. virens in both $\mathrm{L}$ and $\mathrm{H}$ treatm ents. This agrees with higher pyrene concentrations in the form er species (Figure 2) and a positive correlation between pyrene and GluPyr concentrations in $N$. ciliata $\left(R^{2}=0.252, p=0.012\right)$, but not in $A$. virens (Tables S18 and S19). In H exposed A. virens, low GluPyr concentrations $\mathrm{m}$ ay be due to too low pyrene concentrations in $A$. virens to lead to significant induction of Phase I (e.g., pyrene hydroxylase) and thus, consecutive Phase II (UDPGT) biotransform ation 


\section{Chapter 4}

[233]. However, GluPyr/Pyr ratios in $\mathrm{H}$ exposed A. virens were on average 3.5 tim es higher than in $N$. ciliata. This shows that biotransform ation rates were lim ited am ong polychaete species according to the low level of exposure (Table 4), although a higher induction of CYP450 enzym es m ay be expected inA. virens than $N$. ciliata possibly due to a stronger bioactivity of PAHs and additional inducer chem icals, such as PBDEs (Table S4;[289]), in the broad om nivore $A$. virens than in $N$. ciliata $[136,235]$.

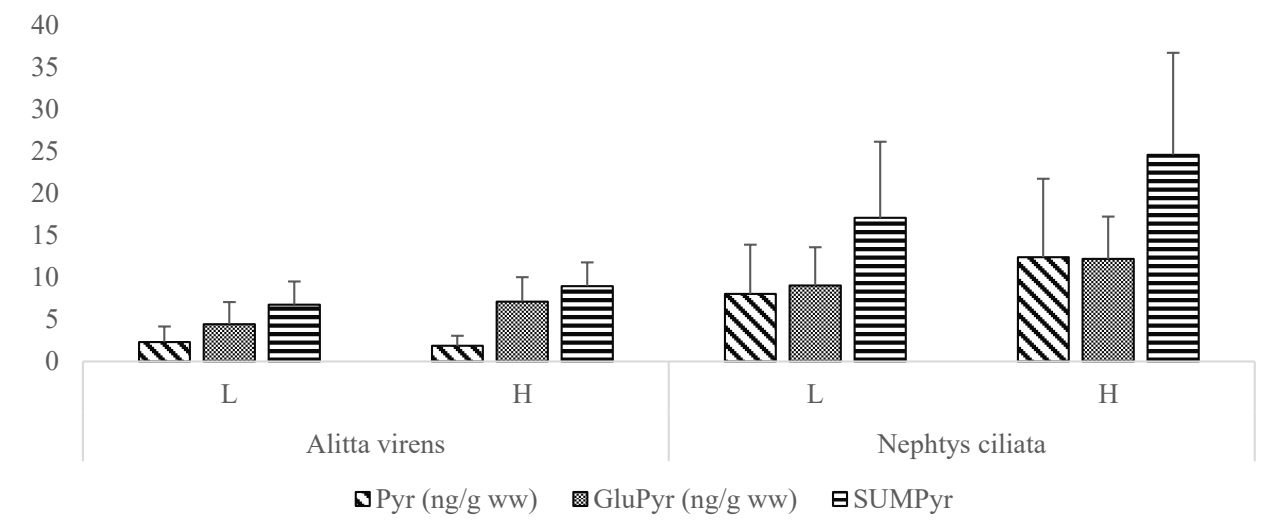

Figure 2. Concentrations of pyrene (Pyr; ng/g wet wt.), pyrene-1-glucuronide (GluPyr; ng/g wet wt.) and the sum of both com pounds(SUMPyr) in whole body tissue of tem perate (Alitta virens) and Arctic (Nephtys ciliata) polychaete species exposed to the low (L) and high (H) sedim ent treatm ents. 


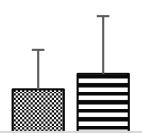

$\mathrm{L}$

Figure 3. Concentrations of pyrene (Pyr; ng/g wet wt.), pyrene-1-glucuronide (GluPyr; ng/g wet wt.) and the sum of both com pounds (SUMPyr) in soft body tissue of tem perate (Limecola balthica) and Arctic (Macoma calcarea) bivalve species exposed to the low (L) and high $(\mathrm{H})$ sedim ent treatm ents.

Table 4. Pyrene, 1-hydroxypyrene and pyrene-1-glucuronide concentrations (geom ean [m in $\mathrm{m}$ ax]; ng/g wet wt.) in Arctic (Macoma calcarea, Nephtys ciliata) and tem perate species (Limecola balthica, Alitta virens).

\begin{tabular}{ccccc} 
Species & Treatm ent & Pyr & OHPyr & GluPyr \\
\hline \multirow{2}{*}{ Limecola balthica } & BSL & $11.6(<\mathrm{LOQ}-36.4)$ & $0.4(<\mathrm{LOD}-2.98)$ & $17.4(<\mathrm{LOD}-74.0)$ \\
& $\mathrm{BSH}$ & $11.8(<\mathrm{LOQ}-26.7)$ & $0.4(<\mathrm{LOD}-2.22)$ & $12.1(<\mathrm{LOQ}-50.7)$ \\
\hline \multirow{2}{*}{ Macoma calcarea } & $\mathrm{BSL}$ & $3.6(0.7-12.3)$ & $0.5(<\mathrm{LOD}-1.5)$ & $7.8(<\mathrm{LOD}-34.7)$ \\
& $\mathrm{BSH}$ & $5.8(1.1-21.3)$ & $0.6(<\mathrm{LOD}-3.1)$ & $7.1(<\mathrm{LOQ}-41.6)$ \\
\hline \multirow{2}{*}{ Alitta virens } & PSL & $1.7(0.5-5.4)$ & $0.1(<\mathrm{LOD}-1.5)$ & $3.9(2.2-10.0)$ \\
& PSH & $1.5(0.5-4.3)$ & $<\mathrm{LOD}$ & $6.7(4.5-13.7)$ \\
\hline \multirow{2}{*}{ Nephtys ciliata } & PSL & $5.9(2.0-15.5)$ & $0.2(<\mathrm{LOD}-0.9)$ & $8.2(4.1-20.9)$ \\
& PSH & $9.2(3.6-28.5)$ & $0.3(<\mathrm{LOD}-3.7)$ & $11.4(6.4-22.2)$ \\
\hline
\end{tabular}

Pyr: Pyrene; OHPyr: 1-hydroxypyrene; GluPyr: pyrene-1-glucuronide; LOD: lim it of detection; LOQ: lim it of quantification. Additional abbreviations are defined in Table 1.

Mean GluPyr concentrations in the tem perateL. balthica were higher than in the Arctic $M$. calcarea. This com plies with higher pyrene concentrations inL. balthica than in M. calcarea (Figure 3). In $\mathrm{H}$ exposed bivalves, pyrene concentrations were within the sam e range as observed concentrations of another 4-ring PAH, chrysene, in scallops (Chlamys farreri) after exposure to $0.1 \mu \mathrm{g} / \mathrm{L}$ (i.e., 35 - $45 \mathrm{ng}$ chrysene/g dry wt. [290]). Within such range, concentrations of chrysene in scallops did not reveal a significant correlation with 7ethoxyresorufin O-deethylase activity, which is the catalytic m easurem ent of CYP450 


\section{Chapter 4}

induction. Absence of CYP induction would explain sim ilar biotransform ation rates between L. balthica and M. calcarea (Figure 3), but it would not account for a seem ingly decreasing trend in GluPyr concentration with PAH exposure (Table 4). This stresses the im portanceof considering different Phase II biotransform ation pathways for the characterization and com parison of pyrene $m$ etabolite patterns am ong bivalve $\$ 288,291]$.

In sum $m$ ary, pyrene m etabolite patterns appeared to be sim ilar am ong all target species after exposure to PAHs in sedim ent at the different sedim ent treatm ent levels. However, GluPyr yielded different concentration profiles between Arctic (N. ciliata) and tem perate polychaetes (A. virens) exposed to the high treatm ent, possibly related to a higher induction of CYP450 enzym es in $A$. virens. Besides, the suitability of this $\mathrm{m}$ etabolite as biom arker of exposure could be confirm ed for $N$. ciliata according to its positive correlation with pyrene exposure. In bivalves, both tem perate (L. balthica) and Arctic species (M. calcarea) showed sim ilar GluPyr concentration profiles, although lower GluPyr concentrations with PAH exposure pointed towards the activation of alternative Phase II biotransform ation pathways in $L$. balthica.

\section{Conclusions and Implications}

No effects of environm entally relevant PAH concentrations in sedim ent were found on biom arkers AChE, GST and AOX activities in digestive gland of A. borealis. Overall exposure levels were probably too low to induce detectable biom arker responses in $A$. borealis digestive gland, while relatively low AChE levels and high baseline AOX levels potentially indicated a stressed physiological status of $A$. borealis. A further identification of crucial confounding param eters in both enzym atic induction and inhibition, as well as optim izing the biom arker assays for Arctic species is therefore needed for an appropriate evaluation.

In Arctic and tem perate benthic invertebrates sim ilarly exposed to PAHs, the concentrations of Phase I and Phase II biotransform ation $m$ etabolites of pyrene did not increase with pyrene exposure. Biotransform ation rates appeared to be lim ited by low exposure to sedim enbound chem icals am ong bivalve and polychaete species, although glucuronide conjugates represented up to $74 \%$ and $79 \%$ of the total pyrene concentrations in Arctic bivalves and tem perate polychaetes, respectively. This shows that in order to characterize and quantify 
PAH exposure am ong invertebrate species, the m etabolic products of Phase I and Phase II biotransform ation should be equally considered.

\section{Acknowledgements}

We thank Axel Meldahl (captain of the research vessel MS Teisten of Kings Bay AS [NyÅlesund, Svalbard] in sum m er 2014), Marten Loonen, Ben Frederiks, Noël Diepens, Livia Sidney, Verena Mohaupt, Thom as Dupeyron, Kerstin Binder, Anna Rom an and Wouter van Duin for their help during field and experim ental sam pling. Manu Soto, Eider Bilbao and Irune Valenciano (Plentzia Marine Station, University of the Basque Country) are highly thanked for their logistic assistance and fruitful discussions. This work was supported by Equinor ASA (Norway) (SAP 4502687550) and the Wageningen UR TripleP@Sea innovation program $\mathrm{m}$ e (The Netherlands) (KB14-007). 


\section{Chapter 4}

\section{Supporting Information}

\section{Field sampling}

Sampling of Arctic species. Sam pling in Kongsfjorden Bay (Svalbard, Norway) was m ainly perform ed along a transect from Tønsneset $\left(790^{\prime} 22^{\prime \prime} \mathrm{N}, 11^{\circ} 57^{\prime} 10^{\prime \prime} \mathrm{E}\right)$ to Blom strandhalvøya

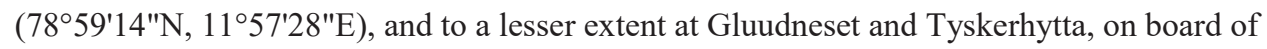
research vessel MS Teisten (Kings Bay AS, Ny-Ålesund) on 8 to 26 Septem ber 2014. Biota sam ples were collected using a Van Veen grab $\left(0.1 \mathrm{~m}^{2}\right)$. Three Arctic $\mathrm{m}$ arine benthic invertebrate species with different feeding behaviours were collected: Astarte borealis (m olusc; suspension feeder [Schum acher, 1817]), Macoma calcarea (m ollusc; surface deposit and suspension feeder [Gm elin, 1791]) andNephtys ciliata (polychaete; predator and deposit feeder [O.F. Müller, 1776]).

Sampling of temperate species. Limecola balthica (m ollusc; surface deposit and suspension feeder [Linnaeus, 1758]) were collected at low tide at the Oesterdam (The Netherland, $51^{\circ} 26^{\prime} 24^{\prime \prime} \mathrm{N}, 4^{\circ} 13^{\prime} 16^{\prime \prime E}$ ) on 16 to 17 July 2014. Alitta virens (polychaete; predator and deposit feeder [Sars, 1835]) were obtained from a professional bait farm, Topsy baits (Wilhelm inadorp, the Netherlands).

\section{Acclimatization}

Arctic species were kept in glass aquaria with aerated, filtered $(20 \mu \mathrm{m})$ and UV-treated sea water from the fjord $\left(3^{\circ} \mathrm{C}\right)$ for 2 to $6 \mathrm{~d}$ before start of the experim ent. In the case of $N$. ciliata, a thin layer of sieved $(1 \mathrm{~m} \mathrm{~m} \varnothing)$ sedim ent from the original sam pling area was also included. Anim als were not fed during acclim atization.

Tem perate species were kept in glass aquaria with aerated, filtered $(0.2 \mu \mathrm{m})$ sea waterfor $5 \mathrm{~d}$ and were fed once with spiked ground fish food (TetraMin) suspended in deionised water at the start of the acclim atization. In order to have sufficient food supply, $10 \mathrm{~m} g$ of dry food for A. virens and $3 \mathrm{mg}$ (shell length $\geq 15 \mathrm{~m} \mathrm{~m}$ ) or $1.5 \mathrm{~m} \mathrm{~g}$ (shelength $<15 \mathrm{~m} \mathrm{~m}$ ) forl. balthica was added per individual.

Water quality variables such as $\mathrm{pH}$, dissolved oxygen, salinity and tem perature were $\mathrm{m}$ easured every two daysduring exposure tim e (Tables S2 andS3). 


\section{Sediment collection}

A m oderately contam inated $\mathrm{sb}$-toxic $\mathrm{m}$ arine sedim ent was prepared by $\mathrm{m}$ ixing a non contaminated 'clean' sediment with a naturally contaminated harbour sediment. Batches of m uddy sedim ent (132 L) and coarse sedim ent (176 L) were collected in the Oosterchelde estuary (The Netherlands, 51 $36^{\prime} 13^{\prime \prime} \mathrm{N}, 3^{\circ} 47^{\prime} 49^{\prime \prime} \mathrm{E}$ ) at low tide on 24 to 25 April 2014 and 2 May 2014. Coarse sedim ent (0.5-1 $\mathrm{m} \mathrm{m}$ grain size) was sieved in the field with a $1 \mathrm{~m} \mathrm{~m}$ sieve whereas m uddy sedim ent $(\varangle 0.5 \mathrm{~m} \mathrm{~m}$ grain size $)$ was sieved at laboratory inside a $\mathrm{m} \mathrm{m}$ sieve with som e fltered sea water $(0.2 \mu \mathrm{m})$. Once sieved both sam ples were stored at $3{ }^{\circ} \mathrm{C}$.

A batch of harbour sedim ent $(30 \mathrm{~L})$ was collected near Nesserdijk (Rotterdam, the Netherlands, 51 $54^{\prime} 14 " N$, 4³1'17"E) by Nautisch Service Centrum in April 2014 and sieved with a 1-m msieve on 1 May 2014. A subsam ple of the sieved wet harbour sedim ent $(800 \mathrm{~m} \mathrm{~L})$ was sent to Wageningen Marine Research laboratories (IJm uiden, the Netherlands) for further chem ical analyses (Table S4).

\section{Test species}

Arctic experiment. A. borealis, M. calcarea and N. ciliata were obtained as described in the field sam pling section.A. borealis random ly selected healthy individuals with an average and standard deviation (SD) shell length of 31.30 (4.63) $\mathrm{m} \mathrm{m}$ and wet w.t(flesh) of 7.47 (4.16) $\mathrm{g}$ were used. As for M. calcarea and N. ciliata, we did not $\mathrm{m}$ easure any $\mathrm{m}$ orphological param eters due to the scarcity of individuals. Anim als were not fed during the acclim atization, neither during the exposure experim ents.

Temperate experiment. L. balthica and A. virens were obtained as described in the field sam pling section.L. balthica random ly selected healthy individuals with an average (SD) shell length of 13.49 (2.46) $\mathrm{m} \mathrm{m}$ and wet $\mathrm{w}$. (shell + flesh) of $0.47(0.31) \mathrm{g}$ were used. $A$. virens random ly selected healthy individualswith an average (SD) length of $10.83(1.70) \mathrm{cm}$ and wet wt. of $2.75(0.98) \mathrm{g}$ were used. Anim als were fed once at the beginning of the acclim atization.

\section{Pyrene metabolites analysis}

Chemicals. Pyrene (98\%) and 1-hydroxypyrene (OHPyr) (98\%) were purchased from Sigm a Aldrich. Pyrenyl-1-O-glucuronide (GluPyr) (98.2\%) was supplied by Isostandards Material. 


\section{Chapter 4}

The dilutions at lower concentrations were prepared daily, depending on the experim ent. All chem ical standards were stored at $4{ }^{\circ} \mathrm{C}$ and stock solutions at $-20^{\circ} \mathrm{C}$. Acetone, $\mathrm{m}$ ethanol and acetonitrile (all HPLC grade) were purchased from Macrom Fine Chem icals. For filtration $0.45 \mu \mathrm{m}$ polyam ide filters (Macherey Nagel) were used. Oasis HLB $(200 \mathrm{~m}$ g) cartridges were purchased from Waters in order to perform cleanup step.

High-performance liquid chromatograph with a fluorescence detector (HPLC-FLD) analysis. A high-perform ance liquid chrom atograph (Agilent Technologies, Series 1100) with a fluorescence detector (FLD, Agilent Technologies, Series 1100) was used for all the quantitative $\mathrm{m}$ easurem ents. The chrom atographic $\mathrm{m}$ ethod was $\mathrm{m}$ odified froßeach et al. [292]. A Supelcolsil LC-PAH HPLC colum $\mathrm{n}(10 \mathrm{~cm} \times 4.6 \mathrm{~m} \mathrm{~m}, 3 \mu \mathrm{m})$ was used for the separation. Mobile phases were prepared: of A: only Milli-Q water, B:

m ethanol:acetonitrile:MilliR water (38:57:5, v/v/v), both with $10 \mathrm{~m} \mathrm{M}$ am m onium acetate. The solvent gradient was $15 \mathrm{~m}$ in, starting with $20 \% \mathrm{~B}$ with a linear gradual increase to $100 \%$ B from 0 to $2.5 \mathrm{~m}$ inwith a $4 \mathrm{~m}$ in hold at $100 \% \mathrm{~B}$ and continued with a linear decrease to $80 \%$ B from 6.5 to $8.5 \mathrm{~m}$ in with a $6.5 \mathrm{~m}$ in hold at $80 \% \mathrm{~B}$. An injection volum e of $5 \mu \mathrm{L}$ and a flow rate of $800 \mu \mathrm{L} / \mathrm{m}$ in were used throughout. Fluorescence detection was perform ed at an excitation/em ission wavelength pair of 235/388 nm for pyrene, OHPyr and GluPyr.

Lim its of detection (LODs) were 0.2, 0.35 and $0.20 \mathrm{ng} / \mathrm{m}$ L for pyrene, OHPyr and GluPyr, respectively. LODs were expressed in biom ass units taking 0.4, 0.8, 0.05 and $1.7 \mathrm{~g}$ as the average wet wt. per sam ple ofM. calcarea, $N$. ciliata, L. balthica, A. virens, respectively. Therefore, pyrene, OHPyr and GluPyr LODs were recalculated as $0.5,0.88$ and $0.5 \mathrm{ng} / \mathrm{g}$ for M. calcarea; $0.25,0.44$ and $0.25 \mathrm{ng} / \mathrm{g}$ for N. ciliata; 4,7 and $4 \mathrm{ng} / \mathrm{g}$ for L. balthica; and 0.12 , 0.21 and $0.12 \mathrm{ng} / \mathrm{g}$ for $A$. virens. Sam ples with pyrene or GluPyr below the lim it of quantification (LOQ) were assigned a "LOQ/2" value. 
Chapter 4

Table S1. Overview of the num ber of experim ental aquaria per species and sedim ent treatm ent.

\begin{tabular}{lrrrrrrr} 
& & \multicolumn{5}{c}{ Treatment $(n)^{\mathrm{a}}$} \\
\cline { 3 - 9 } Experim ent & Species & Ind./aq. & BSL & BSM & BSH & PSL & PSH \\
\hline \multirow{3}{*}{ Arctic } & Macoma calcarea & $40-50$ & 2 & n.a. & 2 & & \\
\cline { 2 - 9 } & Astarte borealis & 25 & 4 & 4 & 6 & & \\
\cline { 2 - 9 } & Nephtys ciliata & 20 & & & & 2 & 3 \\
\hline \multirow{2}{*}{ Tem perate } & Limecola balthica & 50 & 2 & n.a. & 3 & & \\
\cline { 2 - 8 } & Alitta virens & 16 & & & & 3 & 4 \\
\hline
\end{tabular}

${ }^{\mathrm{a}} n$ : num ber of replicates per sedim ent treatm ent.

${ }^{\mathrm{b}}$ Ind./aq.: num ber of organism s per aquarium .

BSL: Low Bivalve Sedim ent;BSM: Medium Bivalve Sedim ent:BSH: High Bivalve Sedim ent; PSL: Low

Polychaete Sedim ent; PSH: High Polychaee Sedim ent; n.a.: not available 


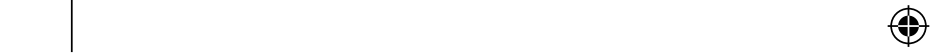

\section{Chapter 4}
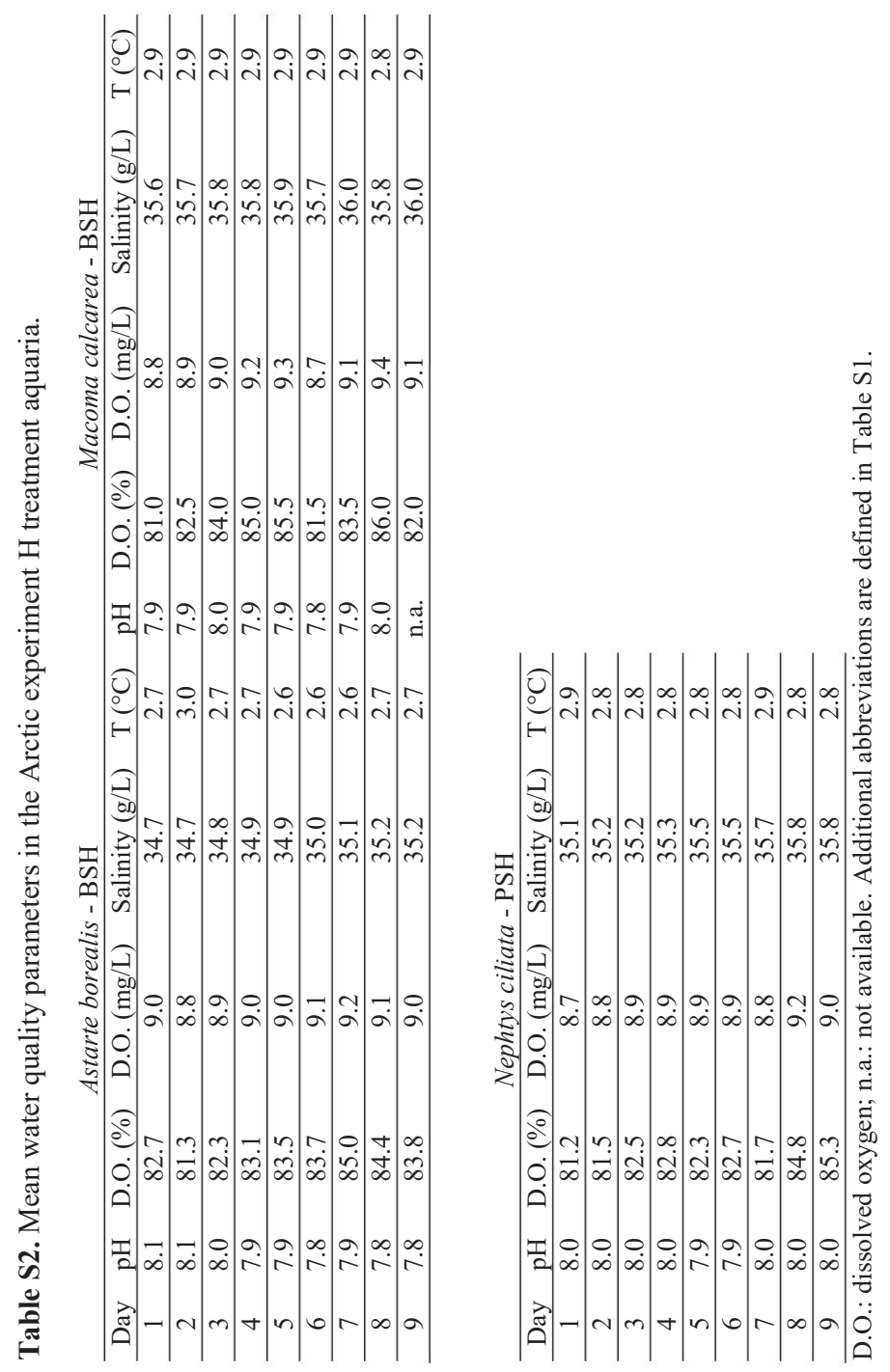

$\oplus$ 


\section{Chapter 4}

Table S3. Mean water quality param eters in thetem perate experim ent $\mathrm{H}$ treatm ent aquaria.

Limecola balthica - BSH

\begin{tabular}{cccccc}
\hline Day & $\mathrm{pH}$ & D.O. $(\%)$ & D.O. $(\mathrm{m} \mathrm{g} / \mathrm{L})$ & Salinity $(\mathrm{g} / \mathrm{L})$ & $\mathrm{T}\left({ }^{\circ} \mathrm{C}\right)$ \\
\hline 1 & 8.2 & 83.8 & 6.6 & 32.8 & 17.8 \\
\hline 2 & n.a. & 80.3 & 6.3 & n.a. & 17.8 \\
\hline 3 & n.a. & 79.3 & 6.2 & n.a. & 17.7 \\
\hline 4 & 8.2 & 80.8 & 6.2 & 33.3 & 18.0 \\
\hline 5 & 8.2 & 82.0 & 6.4 & 33.5 & 18.1 \\
\hline 6 & 8.2 & 82.2 & 6.4 & 33.6 & 17.9 \\
\hline 7 & 8.3 & 84.2 & 6.5 & 34.1 & 17.8 \\
\hline 8 & 8.2 & 84.2 & 6.5 & 34.5 & 17.8 \\
\hline 9 & 8.3 & 86.0 & 6.6 & 34.7 & 18.1 \\
\hline 10 & 8.3 & 85.2 & 6.6 & 35.0 & 17.9 \\
\hline 11 & 8.3 & 85.3 & 6.6 & 35.4 & 17.9 \\
\hline 12 & 8.3 & 84.5 & 6.5 & 35.7 & 17.9 \\
\hline
\end{tabular}

Alitta virens - PSH

\begin{tabular}{cccccc}
\hline Day & $\mathrm{pH}$ & D.O. $(\%)$ & D.O. $(\mathrm{mg} / \mathrm{L})$ & Salinity $(\mathrm{g} / \mathrm{L})$ & $\mathrm{T}\left({ }^{\circ} \mathrm{C}\right)$ \\
\hline 1 & 8.1 & 79.4 & 6.2 & 33.8 & 18.1 \\
\hline 2 & n.a. & 77.9 & 6.1 & n.a. & 18.1 \\
\hline 3 & n.a. & 75.3 & 5.9 & n.a. & 17.9 \\
\hline 4 & 8.1 & 76.7 & 5.9 & 34.4 & 18.2 \\
\hline 5 & 8.2 & 78.9 & 6.1 & 34.0 & 18.2 \\
\hline 6 & 8.2 & 80.7 & 6.2 & 34.5 & 18.0 \\
\hline 7 & 8.2 & 80.9 & 6.2 & 35.2 & 18.0 \\
\hline 8 & 8.2 & 81.6 & 6.3 & 35.1 & 18.0 \\
\hline 9 & 8.2 & 79.7 & 6.0 & 35.5 & 18.3 \\
\hline 10 & 8.2 & 82.1 & 6.3 & 34.8 & 18.0 \\
\hline 11 & 8.2 & 82.4 & 6.3 & 35.2 & 18.0 \\
\hline 12 & 8.2 & 81.4 & 6.2 & 35.7 & 17.9 \\
\hline
\end{tabular}

D.O.: dissolved oxygen; n.a.: not available. Additional abbreviations are defined in Table S1. 


\section{Chapter 4}

Table S4. Polycyclic arom atic hydrocarbons, polychlorinated biphenylsand polybrom inated diphenyl ethers concentrations in Rotterdam harbour sedim ent (Nesserdijk, Rotterdam ).

\begin{tabular}{lr} 
Com pound & Mean $(\mu \mathrm{g} / \mathrm{kg}$ dry wt. $)$ \\
\hline PHE & 1378 \\
\hline ANT & 459 \\
\hline FLT & 2551 \\
\hline PYR & 1811 \\
\hline BaA & 1174 \\
\hline CHR & 1352 \\
\hline BeP & 510 \\
\hline BbF & 1403 \\
\hline BkF & 536 \\
\hline BaP & 1148 \\
\hline BghiP & 612 \\
\hline dBahA & 135 \\
\hline Ind123P & 1148 \\
\hline CB-28 & $<0.20$ \\
\hline CB-52 & 0.64 \\
\hline CB-101 & 0.97 \\
\hline CB-118 & 0.89 \\
\hline CB-138 & 0.97 \\
\hline CB-153 & 0.64 \\
\hline CB-180 & 0.50 \\
\hline BDE-28 & 0.23 \\
\hline BDE-47 & 2.04 \\
\hline BDE-99 & 6.12 \\
\hline BDE-100 & 0.51 \\
\hline BDE-153 & 10.71 \\
\hline BDE-154+BDE-155 & 0.26 \\
\hline P & 15.
\end{tabular}

PHE: phenanthrene; ANT: anthracene; FLT: fluoranthene; PYR: pyrene; BaA: benz(a)anthracene; CHR:

chrysene; BeP: benzo(e)pyrene; BbF: benzo(b)fluoranthene; BkF: benzo(k)fluoranthene; BaP: benzo(a)pyrene; BghiP: benzo(ghi)perylene; dBahA: dibenz(a,h)anthracene; Ind123P: indeno(1,2,3-cd)pyrene. 


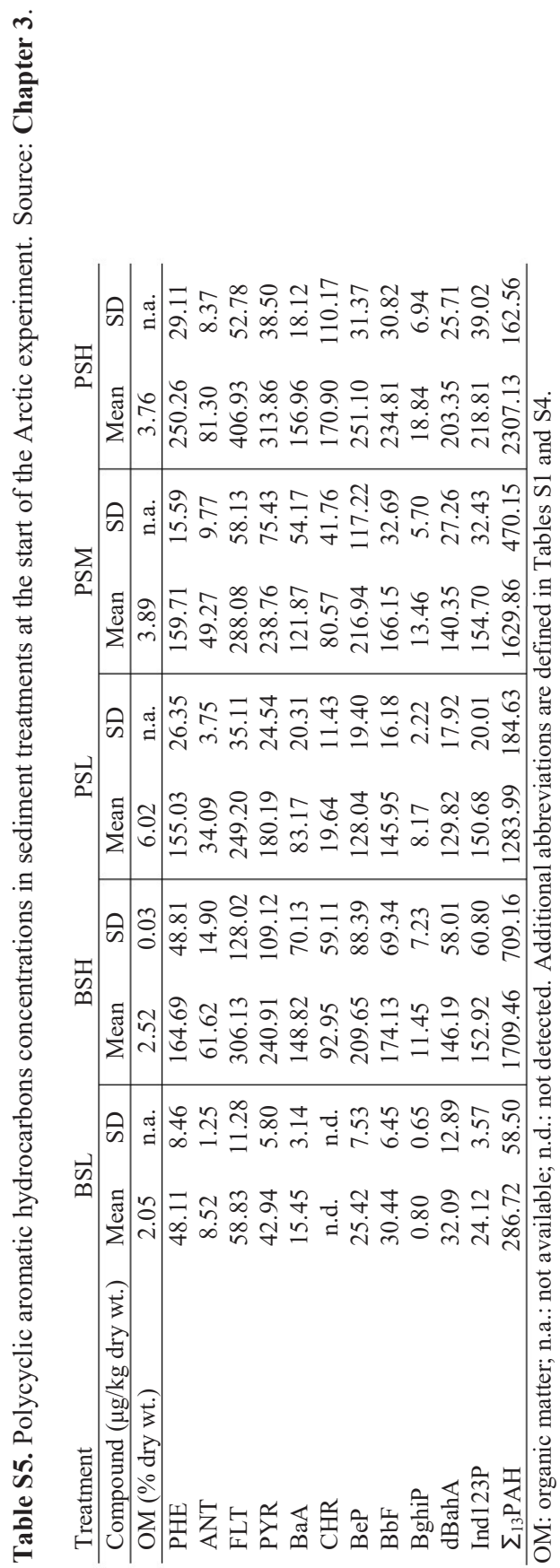




\section{Chapter 4}

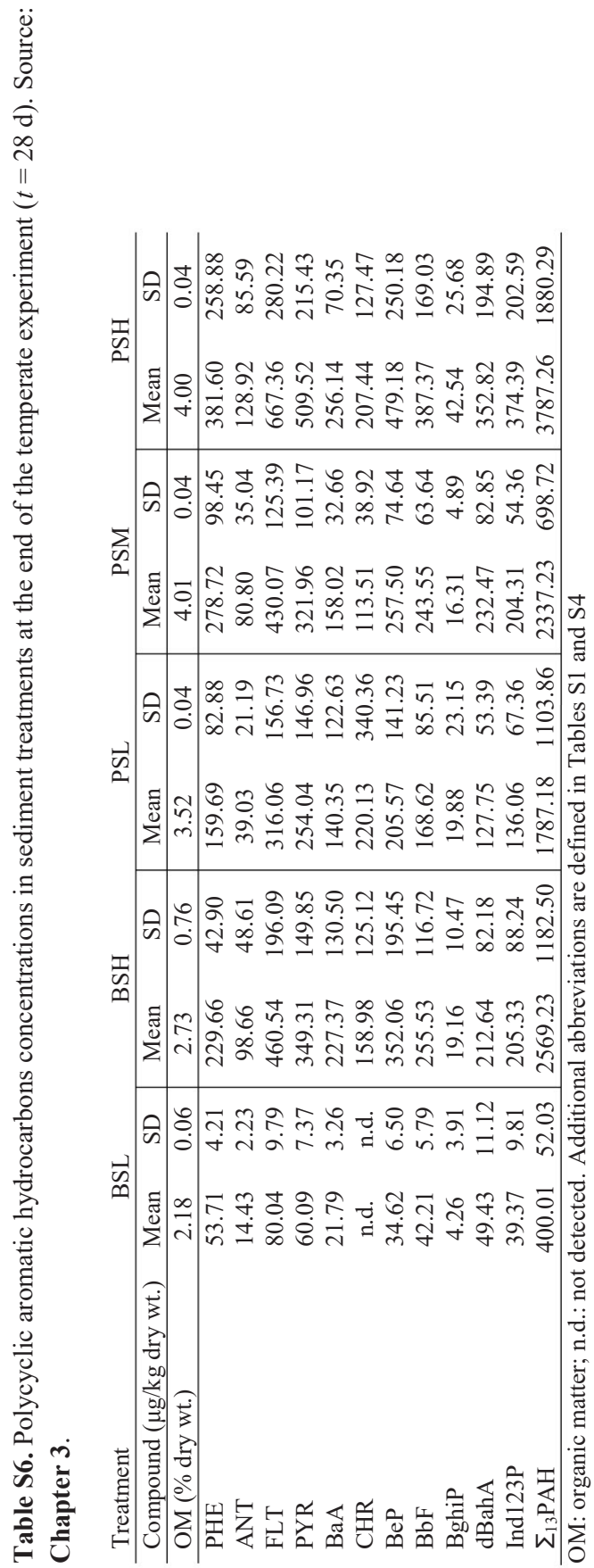




\section{Chapter 4}

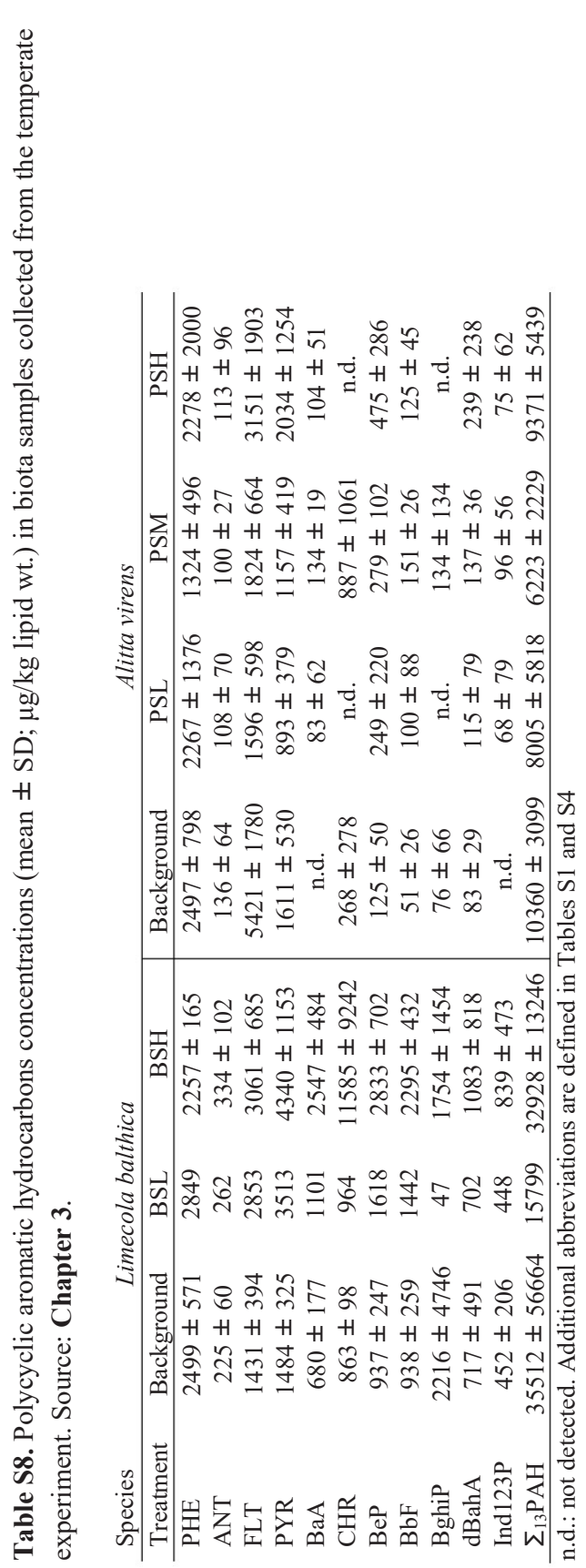

134 
Table S9. Pyrene (Pyr), 1-hydroxypyrene (OHPyr) and pyrene-1-glucuronide (GluPyr) concentrations in polychaete sam ples (ng/g wetwt.).

\begin{tabular}{|c|c|c|c|c|c|}
\hline Species & Treatm ent & Aquarium & Pyr & OHPyr & GluPyr \\
\hline A. virens & $\mathrm{L}$ & PSL-1 & 1.5 & 1.5 & 10 \\
\hline A. virens & $\mathrm{L}$ & PSL-1 & 4.7 & $<$ LOD & 2.4 \\
\hline A. virens & $\mathrm{L}$ & PSL-1 & 5.2 & $<\mathrm{LOD}$ & 2.9 \\
\hline A. virens & $\mathrm{L}$ & PSL-1 & 0.5 & $<\mathrm{LOD}$ & 2.2 \\
\hline A. virens & $\mathrm{L}$ & PSL-2 & 5.4 & $<\mathrm{LOD}$ & 3.5 \\
\hline A. virens & $\mathrm{L}$ & PSL-2 & 1 & $<\mathrm{LOD}$ & 2.7 \\
\hline A. virens & $\mathrm{L}$ & PSL-2 & 3.4 & $<$ LOD & 3.2 \\
\hline A. virens & $\mathrm{L}$ & PSL-2 & 1.3 & $<\mathrm{LOD}$ & 9.2 \\
\hline A. virens & $\mathrm{L}$ & PSL-3 & 1.5 & $<\mathrm{LOD}$ & 3.2 \\
\hline A. virens & $\mathrm{L}$ & PSL-3 & 0.6 & $<\mathrm{LOD}$ & 3.6 \\
\hline A. virens & $\mathrm{L}$ & PSL-3 & 1.8 & $<\mathrm{LOD}$ & 6.1 \\
\hline A. virens & $\mathrm{L}$ & PSL-3 & 1 & $<\mathrm{LOD}$ & 4.3 \\
\hline A. virens & $\mathrm{H}$ & PSH-1 & 1.4 & $<\mathrm{LOD}$ & 8.1 \\
\hline A. virens & $\mathrm{H}$ & PSH-1 & 0.9 & $<\mathrm{LOD}$ & 7.6 \\
\hline A. virens & $\mathrm{H}$ & PSH-1 & 2 & $<$ LOD & 5.7 \\
\hline A. virens & $\mathrm{H}$ & PSH-2 & 1.6 & $<\mathrm{LOD}$ & 13.7 \\
\hline A. virens & $\mathrm{H}$ & PSH-2 & 0.5 & $<\mathrm{LOD}$ & 11.8 \\
\hline A. virens & $\mathrm{H}$ & PSH-3 & 3.6 & $<\mathrm{LOD}$ & 5.1 \\
\hline A. virens & $\mathrm{H}$ & PSH-3 & 1.4 & $<\mathrm{LOD}$ & 4.6 \\
\hline A. virens & $\mathrm{H}$ & PSH-3 & 1.1 & $<\mathrm{LOD}$ & 7 \\
\hline A. virens & $\mathrm{H}$ & PSH-3 & 1.7 & $<\mathrm{LOD}$ & 4.8 \\
\hline A. virens & $\mathrm{H}$ & PSH-4 & 4.3 & $<\mathrm{LOD}$ & 6.2 \\
\hline A. virens & $\mathrm{H}$ & PSH-4 & 3.1 & $<\mathrm{LOD}$ & 6.4 \\
\hline A. virens & $\mathrm{H}$ & PSH-4 & 0.6 & $<\mathrm{LOD}$ & 4.5 \\
\hline N. ciliata & $\mathrm{L}$ & PSL-1 & 3 & $<\mathrm{LOD}$ & 4.1 \\
\hline N. ciliata & $\mathrm{L}$ & PSL-1 & 2.8 & 0.6 & 10 \\
\hline N. ciliata & $\mathrm{L}$ & PSL-1 & 11.8 & $<\mathrm{LOD}$ & 6.9 \\
\hline N. ciliata & $\mathrm{L}$ & PSL-1 & 15.5 & $<\mathrm{LOD}$ & 7.5 \\
\hline N. ciliata & $\mathrm{L}$ & PSL-1 & 2.6 & $<\mathrm{LOQ}$ & 9.1 \\
\hline N. ciliata & $\mathrm{L}$ & PSL-1 & 14.3 & $<\mathrm{LOD}$ & 8.7 \\
\hline N. ciliata & $\mathrm{L}$ & PSL-2 & 2.7 & 0.5 & 8.3 \\
\hline N. ciliata & $\mathrm{L}$ & PSL-2 & 2 & 0.8 & 5.6 \\
\hline N. ciliata & $\mathrm{L}$ & PSL-2 & 15.3 & $<\mathrm{LOD}$ & 13.8 \\
\hline N. ciliata & $\mathrm{L}$ & PSL-2 & 2.7 & $<\mathrm{LOQ}$ & 4.5 \\
\hline N. ciliata & $\mathrm{L}$ & PSL-2 & 10.1 & $<\mathrm{LOD}$ & 8.9 \\
\hline N. ciliata & $\mathrm{L}$ & PSL-2 & 13.8 & $<\mathrm{LOD}$ & 20.9 \\
\hline N. ciliata & $\mathrm{H}$ & PSH-2 & 28.5 & $<$ LOD & 22.2 \\
\hline N. ciliata & $\mathrm{H}$ & PSH-2 & 19.1 & $<\mathrm{LOD}$ & 15.7 \\
\hline N. ciliata & $\mathrm{H}$ & PSH-2 & 5.2 & 2.5 & 8.2 \\
\hline N. ciliata & $\mathrm{H}$ & PSH-2 & 27 & $<\mathrm{LOD}$ & 10.9 \\
\hline N. ciliata & $\mathrm{H}$ & PSH-2 & 4.2 & 1.5 & 7.8 \\
\hline N. ciliata & $\mathrm{H}$ & PSH-2 & 4.3 & $<$ LOD & 10 \\
\hline N. ciliata & $\mathrm{H}$ & PSH-5 & 3.6 & 3.7 & 6.4 \\
\hline N. ciliata & $\mathrm{H}$ & PSH-5 & 4.6 & 2.6 & 20.6 \\
\hline N. ciliata & $\mathrm{H}$ & PSH-5 & 15.8 & $<\mathrm{LOD}$ & 10.7 \\
\hline N. ciliata & $\mathrm{H}$ & PSH-6 & 15.8 & $<\mathrm{LOD}$ & 9.3 \\
\hline N. ciliata & $\mathrm{H}$ & PSH-6 & 3.8 & $<\mathrm{LOD}$ & 14.5 \\
\hline N. ciliata & $\mathrm{H}$ & PSH-6 & 16.9 & $<\mathrm{LOD}$ & 10 \\
\hline
\end{tabular}

L: low treatm ent; H: high treatm ent; LOD: lim it of detection; LOQ: lim it of quantification. LOQs: $0.39 \mathrm{ng} / \mathrm{m} \mathrm{L}$ (Pyr), $0.9 \mathrm{ng} / \mathrm{m} \mathrm{L}$ (OHPyr) and $0.38 \mathrm{ng} / \mathrm{m} \mathrm{L}$ (GluPyr). 


\section{Chapter 4}

Table S10. Pyrene (Pyr), 1-hydroxypyrene (OHPyr) and pyrene-1-glucuronide (GluPyr) concentrations in bivalve sam ples (ng/g wet wt.).

\begin{tabular}{|c|c|c|c|c|c|}
\hline Species & Treatm ent & Aquarium & Pyr & OHPyr & GluPyr \\
\hline L. balthica & $\mathrm{L}$ & BSL-1 & 17.90 & 2.18 & 47.51 \\
\hline L. balthica & $\mathrm{L}$ & BSL-1 & 16.50 & 2.04 & 40.94 \\
\hline L. balthica & $\mathrm{L}$ & BSL-1 & 10.50 & 1.87 & 48.87 \\
\hline L. balthica & $\mathrm{L}$ & BSL-1 & 11.60 & $<\mathrm{LOD}$ & 5.40 \\
\hline L. balthica & $\mathrm{L}$ & BSL-1 & 22.70 & $<$ LOD & 5.90 \\
\hline L. balthica & $\mathrm{L}$ & BSL-1 & 19.69 & 2.20 & 56.60 \\
\hline L. balthica & $\mathrm{L}$ & BSL-1 & 17.90 & $<\mathrm{LOD}$ & 7.40 \\
\hline L. balthica & $\mathrm{L}$ & BSL-1 & 13.70 & $<\mathrm{LOD}$ & 6.70 \\
\hline L. balthica & $\mathrm{L}$ & BSL-1 & 22.30 & $<$ LOD & 12.50 \\
\hline L. balthica & $\mathrm{L}$ & BSL-1 & 11.30 & $<\mathrm{LOD}$ & 6.00 \\
\hline L. balthica & $\mathrm{L}$ & BSL-1 & 36.38 & 2.98 & 73.97 \\
\hline L. balthica & $\mathrm{L}$ & BSL-1 & 10.00 & 1.19 & 56.36 \\
\hline L. balthica & $\mathrm{L}$ & BSL-2 & 1.30 & $<$ LOD & 1.30 \\
\hline L. balthica & $\mathrm{L}$ & BSL-2 & 2.40 & $<$ LOD & $<$ LOQ \\
\hline L. balthica & $\mathrm{L}$ & BSL-2 & 14.12 & 1.83 & 50.06 \\
\hline L. balthica & $\mathrm{L}$ & BSL-2 & 9.23 & 1.40 & 46.43 \\
\hline L. balthica & $\mathrm{L}$ & BSL-2 & 9.09 & 1.56 & 34.64 \\
\hline L. balthica & $\mathrm{L}$ & BSL-2 & 13.50 & $<\mathrm{LOD}$ & 11.70 \\
\hline L. balthica & $\mathrm{L}$ & BSL-2 & 6.45 & 1.06 & 45.73 \\
\hline L. balthica & $\mathrm{L}$ & BSL-2 & 11.00 & $<\mathrm{LOD}$ & 6.50 \\
\hline L. balthica & $\mathrm{L}$ & BSL-2 & 13.60 & $<\mathrm{LOD}$ & 4.80 \\
\hline L. balthica & $\mathrm{L}$ & BSL-2 & 13.20 & $<\mathrm{LOD}$ & 15.10 \\
\hline L. balthica & $\mathrm{L}$ & BSL-2 & 24.07 & 2.66 & 67.66 \\
\hline L. balthica & $\mathrm{L}$ & BSL-2 & 7.40 & $<\mathrm{LOD}$ & 22.80 \\
\hline L. balthica & $\mathrm{L}$ & BSL-2 & 8.90 & $<$ LOD & 5.50 \\
\hline L. balthica & $\mathrm{H}$ & BSH-1 & 8.04 & 0.88 & 16.43 \\
\hline L. balthica & $\mathrm{H}$ & BSH-1 & 14.49 & 1.26 & 44.81 \\
\hline L. balthica & $\mathrm{H}$ & BSH-1 & 11.40 & 1.27 & 37.22 \\
\hline L. balthica & $\mathrm{H}$ & BSH-1 & 18.00 & $<\mathrm{LOD}$ & 1.80 \\
\hline L. balthica & $\mathrm{H}$ & BSH-1 & 13.00 & $<$ LOD & 1.40 \\
\hline L. balthica & $\mathrm{H}$ & BSH-1 & 11.90 & $<\mathrm{LOD}$ & 5.00 \\
\hline L. balthica & $\mathrm{H}$ & BSH-1 & 13.10 & $<\mathrm{LOD}$ & 2.20 \\
\hline L. balthica & $\mathrm{H}$ & BSH-2 & 3.30 & $<\mathrm{LOD}$ & 2.10 \\
\hline L. balthica & $\mathrm{H}$ & BSH-2 & 6.34 & 0.96 & 26.35 \\
\hline L. balthica & $\mathrm{H}$ & BSH-2 & 6.89 & 2.03 & 24.31 \\
\hline L. balthica & $\mathrm{H}$ & BSH-2 & 16.72 & 2.22 & 48.66 \\
\hline L. balthica & $\mathrm{H}$ & BSH-2 & 2.90 & $<\mathrm{LOD}$ & 3.90 \\
\hline L. balthica & $\mathrm{H}$ & BSH-2 & 10.88 & 1.47 & 43.56 \\
\hline L. balthica & $\mathrm{H}$ & BSH-2 & 19.60 & $<\mathrm{LOD}$ & 5.00 \\
\hline L. balthica & $\mathrm{H}$ & BSH-2 & 14.31 & 1.66 & 36.31 \\
\hline L. balthica & $\mathrm{H}$ & BSH-2 & $<\mathrm{LOQ}$ & $<\mathrm{LOD}$ & 1.50 \\
\hline L. balthica & $\mathrm{H}$ & BSH-2 & 12.10 & $<\mathrm{LOD}$ & 4.50 \\
\hline L. balthica & $\mathrm{H}$ & BSH-3 & 16.25 & 0.99 & 50.65 \\
\hline L. balthica & $\mathrm{H}$ & BSH-3 & 12.55 & 1.75 & 47.08 \\
\hline L. balthica & $\mathrm{H}$ & BSH-3 & 6.03 & 1.01 & 22.13 \\
\hline L. balthica & $\mathrm{H}$ & BSH-3 & 11.85 & 1.30 & 18.75 \\
\hline L. balthica & $\mathrm{H}$ & BSH-3 & 22.60 & $<\mathrm{LOD}$ & 11.10 \\
\hline L. balthica & $\mathrm{H}$ & BSH-3 & 21.50 & $<\mathrm{LOD}$ & 22.70 \\
\hline L. balthica & $\mathrm{H}$ & BSH-3 & 21.00 & $<\mathrm{LOD}$ & 14.20 \\
\hline L. balthica & $\mathrm{H}$ & BSH-3 & 26.70 & $<\mathrm{LOD}$ & 31.30 \\
\hline M. calcarea & $\mathrm{L}$ & BSL-1 & 2.06 & 0.68 & 4.24 \\
\hline M. calcarea & $\mathrm{L}$ & BSL-1 & 0.70 & 1.10 & 0.70 \\
\hline M. calcarea & $\mathrm{L}$ & BSL-1 & 2.49 & 0.54 & 11.09 \\
\hline M. calcarea & $\mathrm{L}$ & BSL-1 & 5.11 & 0.88 & 23.48 \\
\hline M. calcarea & $\mathrm{L}$ & BSL-1 & 0.70 & 0.90 & 0.30 \\
\hline M. calcarea & $\mathrm{L}$ & BSL-1 & 2.16 & 0.69 & 8.37 \\
\hline
\end{tabular}


Table S10. Continued.

\begin{tabular}{|c|c|c|c|c|c|}
\hline Species & Treatm ent & Aquarium & Pyr & OHPyr & GluPyr \\
\hline M. calcarea & $\mathrm{L}$ & BSL-1 & 3.95 & 0.74 & 18.65 \\
\hline M. calcarea & $\mathrm{L}$ & BSL-1 & 4.10 & $<\mathrm{LOD}$ & $<\mathrm{LOD}$ \\
\hline M. calcarea & L & BSL-1 & 2.80 & 1.10 & $<\mathrm{LOQ}$ \\
\hline M. calcarea & $\mathrm{L}$ & BSL-1 & 5.50 & $<\mathrm{LOD}$ & 5.30 \\
\hline M. calcarea & $\mathrm{L}$ & BSL-1 & 6.52 & 0.79 & 24.78 \\
\hline M. calcarea & $\mathrm{L}$ & BSL-1 & 3.50 & $<\mathrm{LOD}$ & $<\mathrm{LOQ}$ \\
\hline M. calcarea & $\mathrm{L}$ & BSL-1 & 5.41 & 0.89 & $<\mathrm{LOQ}$ \\
\hline M. calcarea & $\mathrm{L}$ & BSL-1 & 5.20 & 1.50 & $<$ LOD \\
\hline M. calcarea & $\mathrm{L}$ & BSL-1 & 4.76 & 0.55 & 15.50 \\
\hline M. calcarea & $\mathrm{L}$ & BSL-1 & 2.92 & 0.33 & 9.40 \\
\hline M. calcarea & $\mathrm{L}$ & BSL-1 & 12.25 & 0.93 & 25.12 \\
\hline M. calcarea & $\mathrm{L}$ & BSL-1 & 5.54 & 1.00 & 21.15 \\
\hline M. calcarea & L & BSL-1 & 3.99 & 0.70 & 26.40 \\
\hline M. calcarea & $\mathrm{L}$ & BSL-1 & 3.10 & $<\mathrm{LOD}$ & 3.20 \\
\hline M. calcarea & $\mathrm{L}$ & BSL-1 & 5.30 & 0.95 & 34.72 \\
\hline M. calcarea & $\mathrm{L}$ & BSL-1 & 4.70 & $<\mathrm{LOD}$ & 2.90 \\
\hline M. calcarea & $\mathrm{L}$ & BSL-1 & 5.64 & 0.79 & 17.74 \\
\hline M. calcarea & $\mathrm{L}$ & BSL-2 & 2.34 & 0.51 & 6.80 \\
\hline M. calcarea & $\mathrm{L}$ & BSL-2 & 3.30 & $<$ LOD & 1.70 \\
\hline M. calcarea & $\mathrm{H}$ & BSH-6 & 2.30 & $<\mathrm{LOD}$ & $<\mathrm{LOD}$ \\
\hline M. calcarea & $\mathrm{H}$ & BSH- 6 & 1.20 & 0.60 & $<\mathrm{LOQ}$ \\
\hline M. calcarea & $\mathrm{H}$ & BSH-6 & 5.90 & $<\mathrm{LOD}$ & 0.50 \\
\hline M. calcarea & $\mathrm{H}$ & BSH-6 & 11.40 & $<$ LOD & 1.70 \\
\hline M. calcarea & $\mathrm{H}$ & BSH-6 & 1.20 & $<\mathrm{LOD}$ & 0.30 \\
\hline M. calcarea & $\mathrm{H}$ & BSH-6 & 1.10 & 1.10 & 0.80 \\
\hline M. calcarea & $\mathrm{H}$ & BSH- 6 & 4.30 & $<$ LOD & 0.40 \\
\hline M. calcarea & $\mathrm{H}$ & BSH-6 & 16.67 & 1.17 & 33.63 \\
\hline M. calcarea & $\mathrm{H}$ & BSH-6 & 8.10 & $<\mathrm{LOQ}$ & 2.00 \\
\hline M. calcarea & $\mathrm{H}$ & BSH-6 & 2.90 & $<\mathrm{LOD}$ & 3.00 \\
\hline M. calcarea & $\mathrm{H}$ & BSH-6 & 6.30 & $<\mathrm{LOD}$ & 3.90 \\
\hline M. calcarea & $\mathrm{H}$ & BSH-6 & 8.30 & $<\mathrm{LOQ}$ & 0.80 \\
\hline M. calcarea & $\mathrm{H}$ & BSH-6 & 13.07 & 1.23 & 15.24 \\
\hline M. calcarea & $\mathrm{H}$ & BSH-6 & 21.30 & $<\mathrm{LOQ}$ & 2.50 \\
\hline M. calcarea & $\mathrm{H}$ & BSH-6 & 17.34 & 1.30 & 24.78 \\
\hline M. calcarea & $\mathrm{H}$ & BSH-6 & 17.39 & 1.66 & 40.16 \\
\hline M. calcarea & $\mathrm{H}$ & BSH-6 & 21.18 & 1.50 & 30.23 \\
\hline M. calcarea & $\mathrm{H}$ & BSH-6 & 3.54 & 1.28 & 32.48 \\
\hline M. calcarea & $\mathrm{H}$ & BSH-6 & 6.11 & 0.89 & 34.12 \\
\hline M. calcarea & $\mathrm{H}$ & BSH-6 & 5.25 & 0.86 & 38.24 \\
\hline M. calcarea & $\mathrm{H}$ & BSH-7 & 6.04 & 1.67 & 41.63 \\
\hline M. calcarea & $\mathrm{H}$ & BSH-7 & 5.72 & 1.37 & 15.23 \\
\hline M. calcarea & $\mathrm{H}$ & BSH-7 & 3.66 & 1.25 & 23.47 \\
\hline M. calcarea & $\mathrm{H}$ & BSH-7 & 3.78 & 1.63 & 29.22 \\
\hline M. calcarea & $\mathrm{H}$ & BSH-7 & 4.83 & 1.84 & 36.21 \\
\hline
\end{tabular}

L: low treatm ent; H: high treatm ent; LOD: lim it of detection; LOQ: lim it of quantification. LOQs: 0.39 ng/m L (Pyr), 0.9 ng/m L (OHPyr) and 0.38 ng/m L (GluPyr). 
Chapter 4
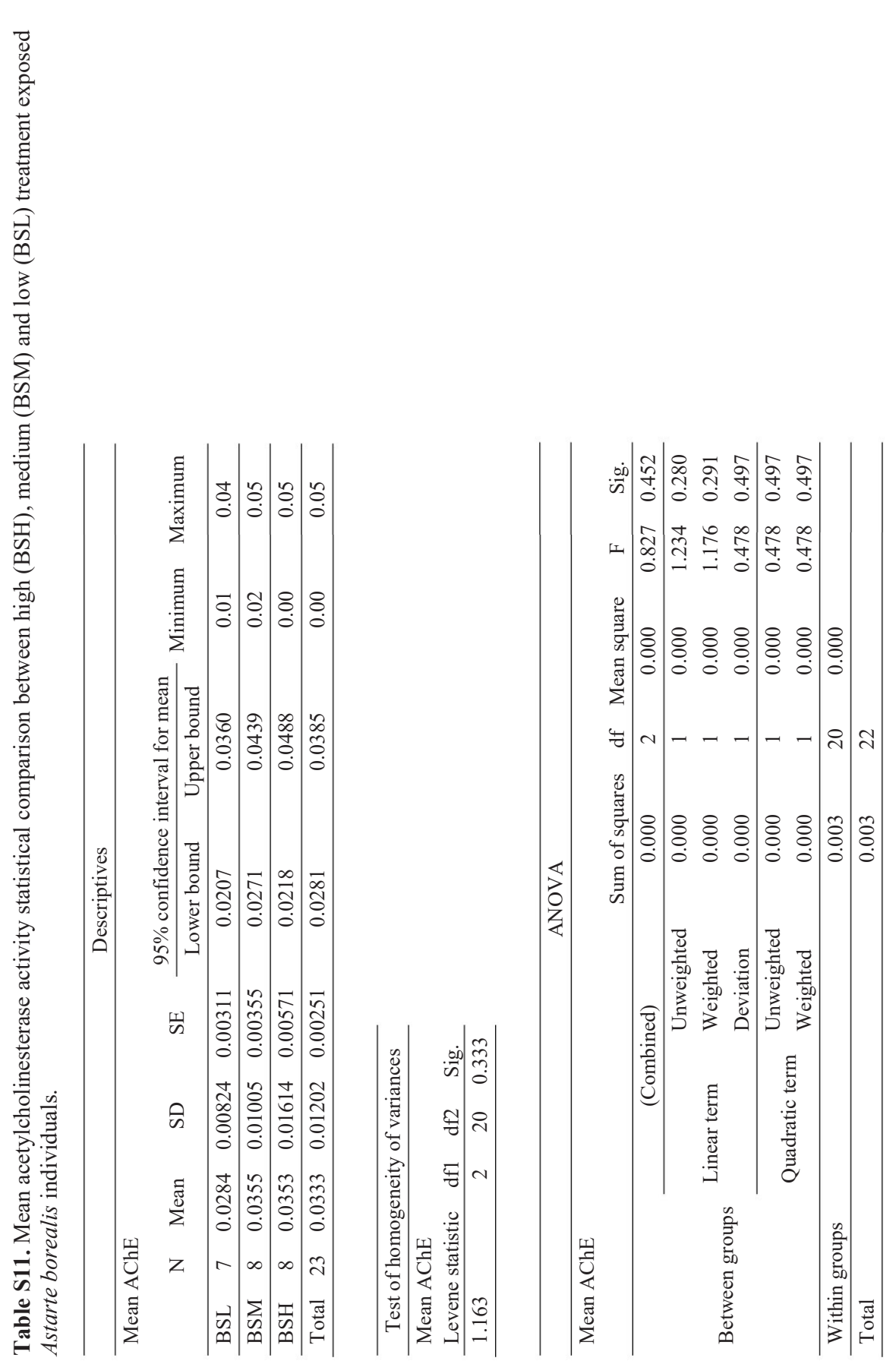
Chapter 4

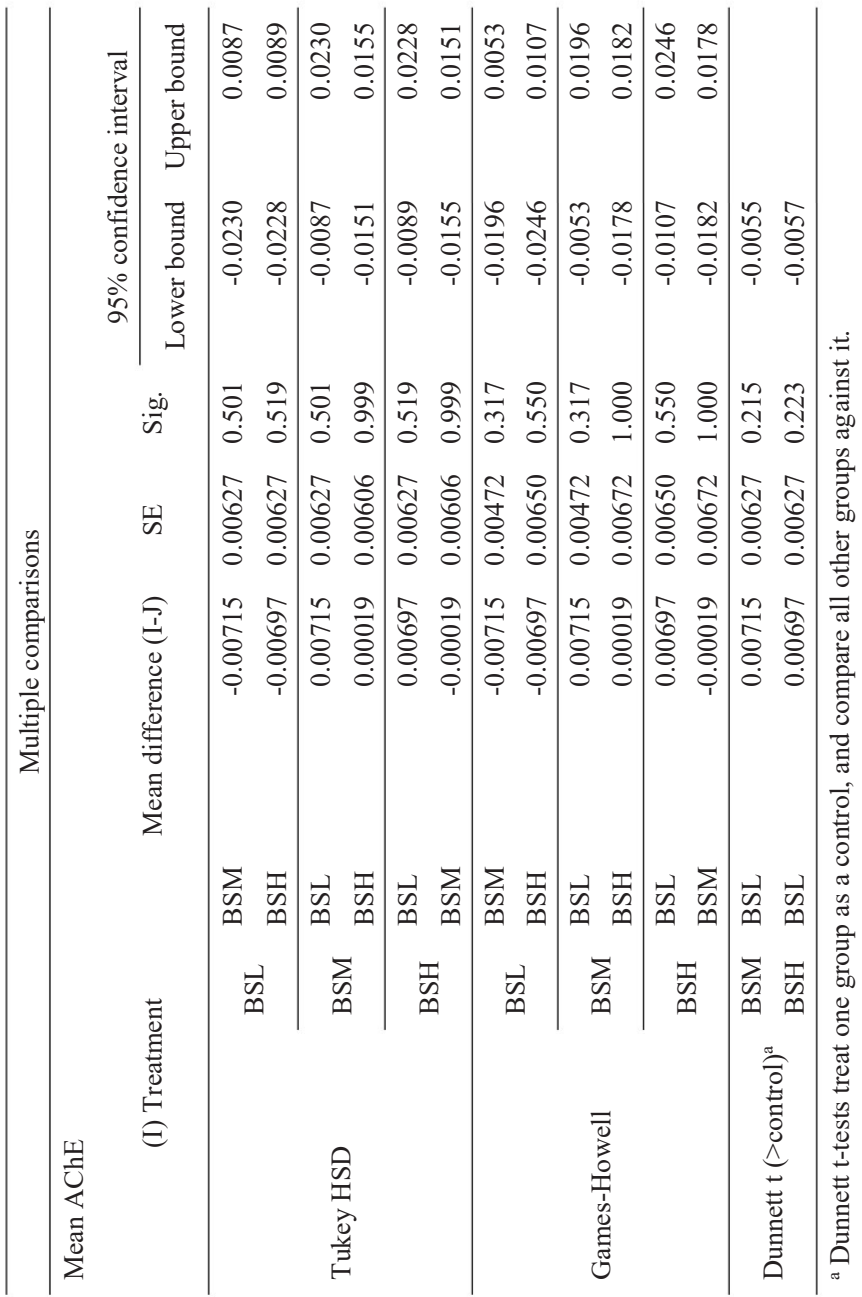

$\oplus$

139 


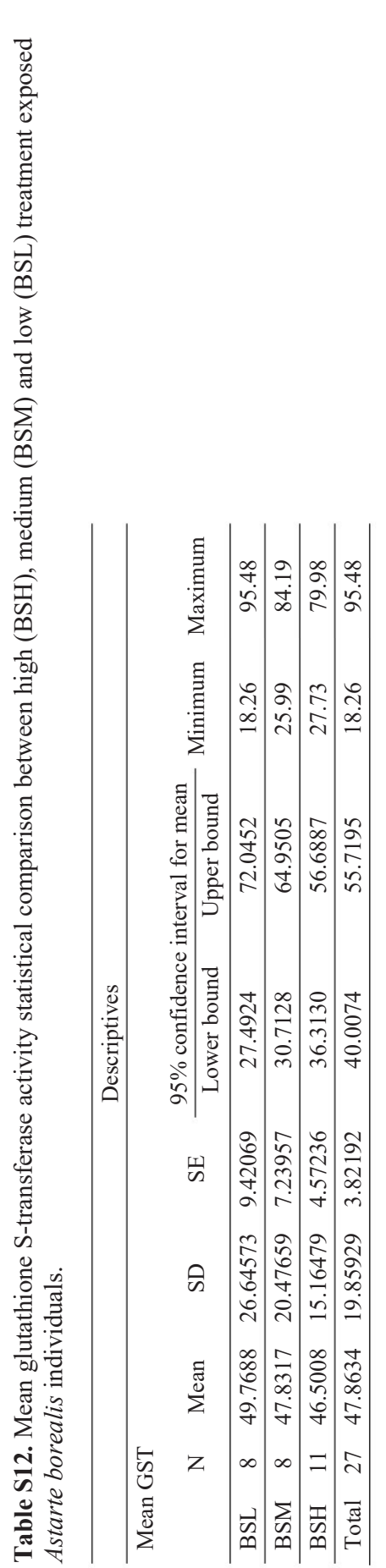




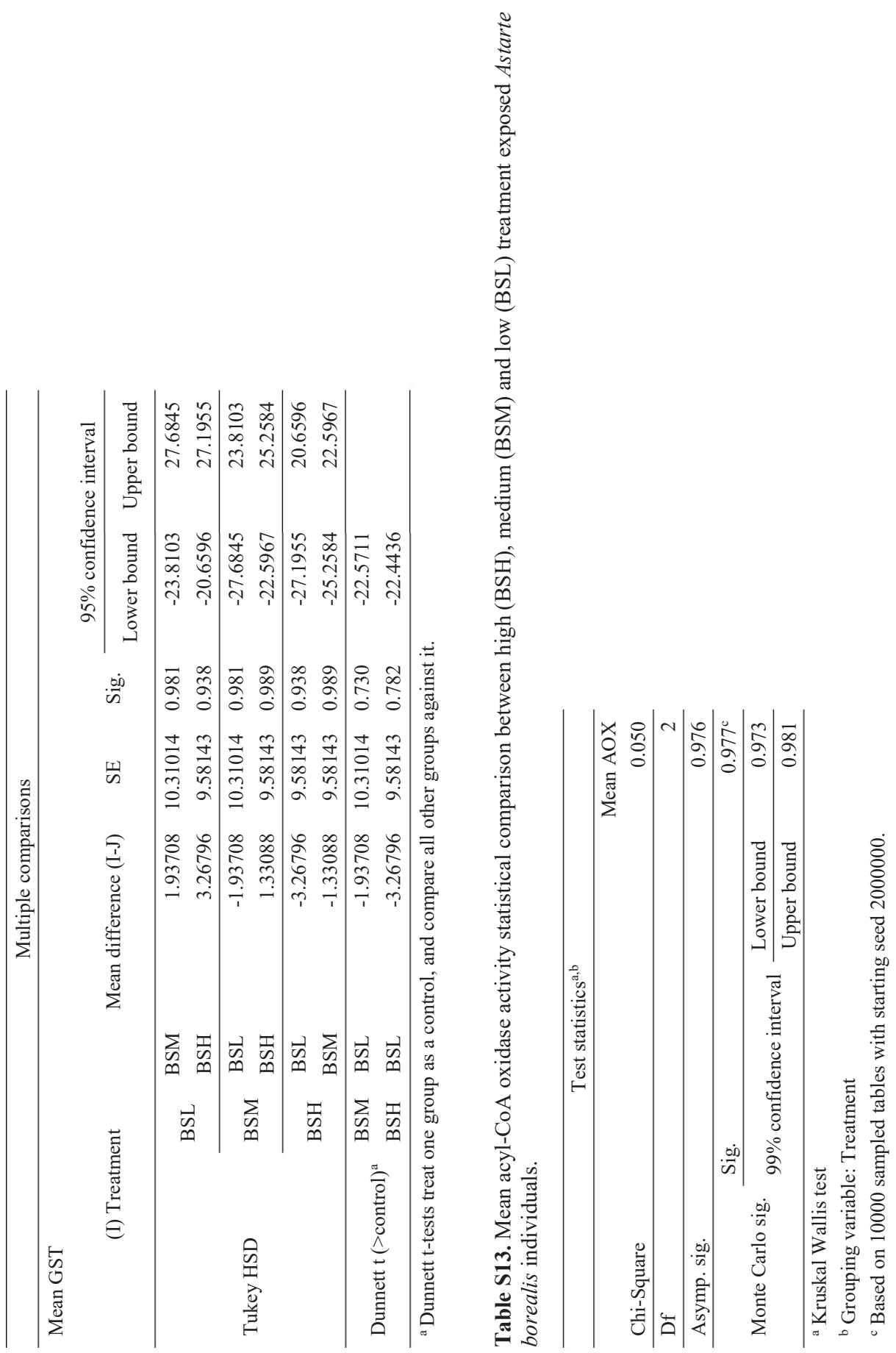




\section{Chapter 4}

Table S14. ANCOVA analysis of pyrene-1-glucuronide (GluPyr) concentration for polychaete species (Alitta virens and Nephtys ciliata). L: low treatm ent (PSL); H: high treatm ent (PSH).

\begin{tabular}{cccc}
\hline \multicolumn{4}{c}{ Levene's test of equality of error variances $^{\mathrm{a}}$} \\
\hline \multicolumn{4}{l}{ Dependent variable: Log_GluPyr } \\
\hline F & df1 & df2 & Sig. \\
1.594 & 1 & 46 & 0.213 \\
\hline
\end{tabular}

Tests the null hypothesis that the error

variance of the dependent variable is equal across groups.

${ }^{a}$ Design: Intercept + Log_Pyr + Treatm ent

\begin{tabular}{lrrrrr}
\hline \multicolumn{7}{c}{ Tests of between-subjects effects } \\
\hline Dependent variable: Log_GluPyr \\
\hline \multicolumn{1}{c}{ Source } & Type III sum of squares & df & Mean square & F & Sig. \\
\hline Corrected m odel & $1.030^{\text {a }}$ & 2 & 0.515 & 12.657 & 0.000 \\
\hline Intercept & 10.735 & 1 & 10.735 & 263.876 & 0.000 \\
\hline Log_Pyr & 0.607 & 1 & 0.607 & 14.933 & 0.000 \\
\hline Treatm ent & 0.350 & 1 & 0.350 & 8.603 & 0.005 \\
\hline Error & 1.831 & 45 & 0.041 & & \\
\hline Total & 37.255 & 48 & & & \\
\hline Corrected total & 2.860 & 47 & & & \\
\hline
\end{tabular}

${ }^{\mathrm{a}} \mathrm{R}$ squared $=0.360$ (adjusted $\mathrm{R}$ squared $=0.332$ )

\begin{tabular}{|c|c|c|c|c|c|c|}
\hline \multicolumn{7}{|c|}{ Param eter estim ates } \\
\hline \multicolumn{7}{|c|}{ Dependent variable: Log_GluPyr } \\
\hline \multirow{2}{*}{ Param eter } & \multirow{2}{*}{ B } & \multirow{2}{*}{$\mathrm{SE}$} & \multirow{2}{*}{$\mathrm{t}$} & \multirow{2}{*}{ Sig. } & \multicolumn{2}{|c|}{$\begin{array}{c}95 \% \text { confidence } \\
\text { interval }\end{array}$} \\
\hline & & & & & $\begin{array}{l}\text { Lower } \\
\text { bound }\end{array}$ & $\begin{array}{l}\text { Upper } \\
\text { bound }\end{array}$ \\
\hline Intercept & 0.804 & 0.054 & 14.804 & 0.000 & 0.694 & 0.913 \\
\hline Log_Pyr & 0.239 & 0.062 & 3.864 & 0.000 & 0.114 & 0.363 \\
\hline [Treatm ent $=\mathrm{L}]$ & -0.171 & 0.058 & -2.933 & 0.005 & -0.289 & -0.054 \\
\hline [Treatm ent $=\mathrm{H}]$ & $0^{\mathrm{a}}$ & & & & & \\
\hline
\end{tabular}

${ }^{\text {a }}$ This param eter is set to zero because it is redundant.

\begin{tabular}{lcccc}
\hline \multicolumn{3}{c}{ Estim ates } \\
\hline Dependent variable: Log_GluPyr \\
\hline \multirow{2}{*}{ Treatm ent } & Mean & SE & \multicolumn{2}{c}{$\begin{array}{c}\text { 95\% confidence } \\
\text { interval }\end{array}$} \\
\cline { 3 - 5 } & & & $\begin{array}{c}\text { Lower } \\
\text { bound }\end{array}$ & $\begin{array}{c}\text { Upper } \\
\text { bound }\end{array}$ \\
\hline $\mathrm{L}$ & $0.761^{\mathrm{a}}$ & 0.041 & 0.678 & 0.844 \\
\hline $\mathrm{H}$ & $0.932^{\mathrm{a}}$ & 0.041 & 0.849 & 1.015 \\
\hline
\end{tabular}

${ }^{\mathrm{a}}$ Covariates appearing in the $\mathrm{m}$ odel are evaluated at the following values: $\log$ Pyr $=0.5385$. 


\begin{tabular}{|c|c|c|c|c|c|}
\hline \multicolumn{6}{|c|}{ Pairwise com parisons } \\
\hline \multicolumn{6}{|c|}{ Dependent variable: Log_GluPyr } \\
\hline \multirow{2}{*}{ (I) Treatm ent } & \multirow{2}{*}{ Mean difference (I-J) } & \multirow{2}{*}{ SE } & \multirow{2}{*}{ Sig. ${ }^{b}$} & \multicolumn{2}{|c|}{$95 \%$ confidence interval for difference } \\
\hline & & & & Lower bound & Upper bound \\
\hline $\mathrm{H}$ & $-0.171^{*}$ & 0.058 & 0.005 & -0.289 & -0.054 \\
\hline $\mathrm{L}$ & $0.171^{*}$ & 0.058 & 0.005 & 0.054 & 0.289 \\
\hline
\end{tabular}

* The $\mathrm{m}$ ean difference is significant at the 0.05 level.

${ }^{\mathrm{b}}$ Adjustm ent for $\mathrm{m}$ ultiple com parisons: Bonferroni.

Table S15. ANCOVA analysis of pyrene-1-glucuronide (GluPyr) concentration for bivalve species (Limecola balthica and Macoma calcarea). L: low treatm ent (BSL); H: high treatm en(BSH).

\begin{tabular}{cccc}
\hline \multicolumn{4}{c}{ Levene's test of equality of error variances $^{\mathrm{a}}$} \\
\hline \multicolumn{1}{l}{ Dependent variable: Log_GluPyr } \\
\hline F & df1 & df2 & Sig. \\
0.108 & 1 & 95 & 0.743 \\
\hline
\end{tabular}

Tests the null hypothesis that the error variance of the

dependent variable is equal across groups.

${ }^{\text {a }}$ Design: Intercept + Log_Pyr + Treatm ent

\begin{tabular}{lrrrrr}
\hline \multicolumn{7}{c}{ Tests of between-subjects effects } \\
\hline Source & $\begin{array}{c}\text { Type III } \\
\text { sum of } \\
\text { squares }\end{array}$ & df & $\begin{array}{c}\text { Mean } \\
\text { square }\end{array}$ & F & Sig. \\
\hline Corrected m odel & $18.669^{\text {a }}$ & 2 & 9.334 & 10.950 & 0.000 \\
\hline Intercept & 0.012 & 1 & 0.012 & 0.014 & 0.906 \\
\hline Log_Pyr & 18.393 & 1 & 18.393 & 21.576 & 0.000 \\
\hline Treatm ent & 0.063 & 1 & 0.063 & 0.074 & 0.786 \\
\hline Error & 80.130 & 94 & 0.852 & & \\
\hline Total & 166.421 & 97 & & & \\
\hline Corrected total & 98.799 & 96 & & & \\
\hline
\end{tabular}

${ }^{\mathrm{a}} \mathrm{R}$ squared $=0.189$ (adjusted $\mathrm{R}$ squared $=0.172$ )

\begin{tabular}{|c|c|c|c|c|c|c|}
\hline \multicolumn{7}{|c|}{ Param eter estim ates } \\
\hline \multirow[t]{3}{*}{ Dependent variable: } & & & & & & \\
\hline & \multirow{2}{*}{$\mathrm{B}$} & \multirow{2}{*}{ SE } & \multirow{2}{*}{$\mathrm{t}$} & \multirow{2}{*}{ Sig. } & \multicolumn{2}{|c|}{$\begin{array}{c}95 \% \text { confidence } \\
\text { interval }\end{array}$} \\
\hline & & & & & $\begin{array}{l}\text { Lower } \\
\text { bound }\end{array}$ & $\begin{array}{l}\text { Upper } \\
\text { bound }\end{array}$ \\
\hline Intercept & 0.049 & 0.224 & 0.219 & 0.827 & -0.395 & 0.493 \\
\hline Log_Pyr & 0.964 & 0.208 & 4.645 & 0.000 & 0.552 & 1.377 \\
\hline$[$ Treatm ent $=\mathrm{L}]$ & -0.051 & 0.188 & -0.272 & 0.786 & -0.424 & 0.322 \\
\hline$[$ Treatm ent $=\mathrm{H}]$ & $0^{\mathrm{a}}$ & & & & & \\
\hline
\end{tabular}




\section{Chapter 4}

\begin{tabular}{|c|c|c|c|c|}
\hline \multicolumn{5}{|c|}{ Estim ates } \\
\hline \multicolumn{5}{|c|}{ Dependent variable: Log_GluPyr } \\
\hline \multirow{2}{*}{ Treatm ent } & \multirow{2}{*}{ Mean } & \multirow{2}{*}{ SE } & \multicolumn{2}{|c|}{$\begin{array}{l}95 \% \text { confidence } \\
\text { interval }\end{array}$} \\
\hline & & & $\begin{array}{l}\text { Lower } \\
\text { bound }\end{array}$ & $\begin{array}{l}\text { Upper } \\
\text { bound }\end{array}$ \\
\hline $\mathrm{L}$ & $0.809^{\mathrm{a}}$ & 0.133 & 0.544 & 1.074 \\
\hline $\mathrm{H}$ & $0.860^{\mathrm{a}}$ & 0.132 & 0.598 & 1.122 \\
\hline
\end{tabular}

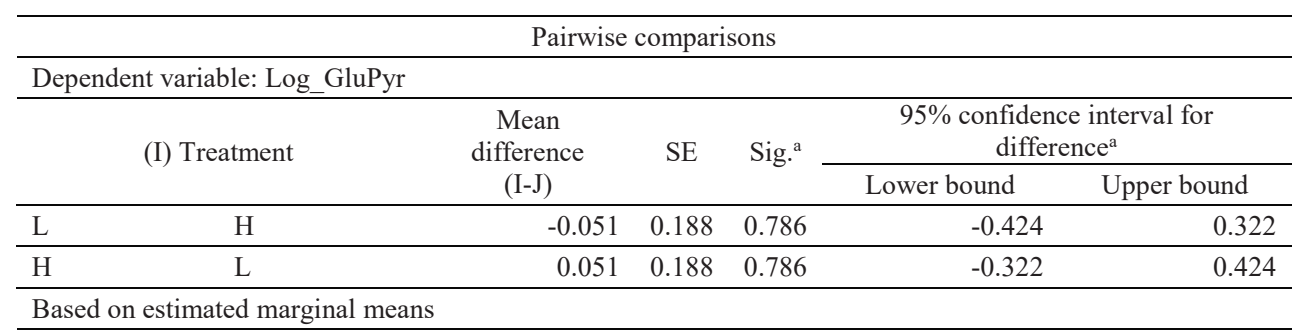

a Adjustm ent for m ultiple com parisons: Bonferroni. 


\section{Chapter 4}
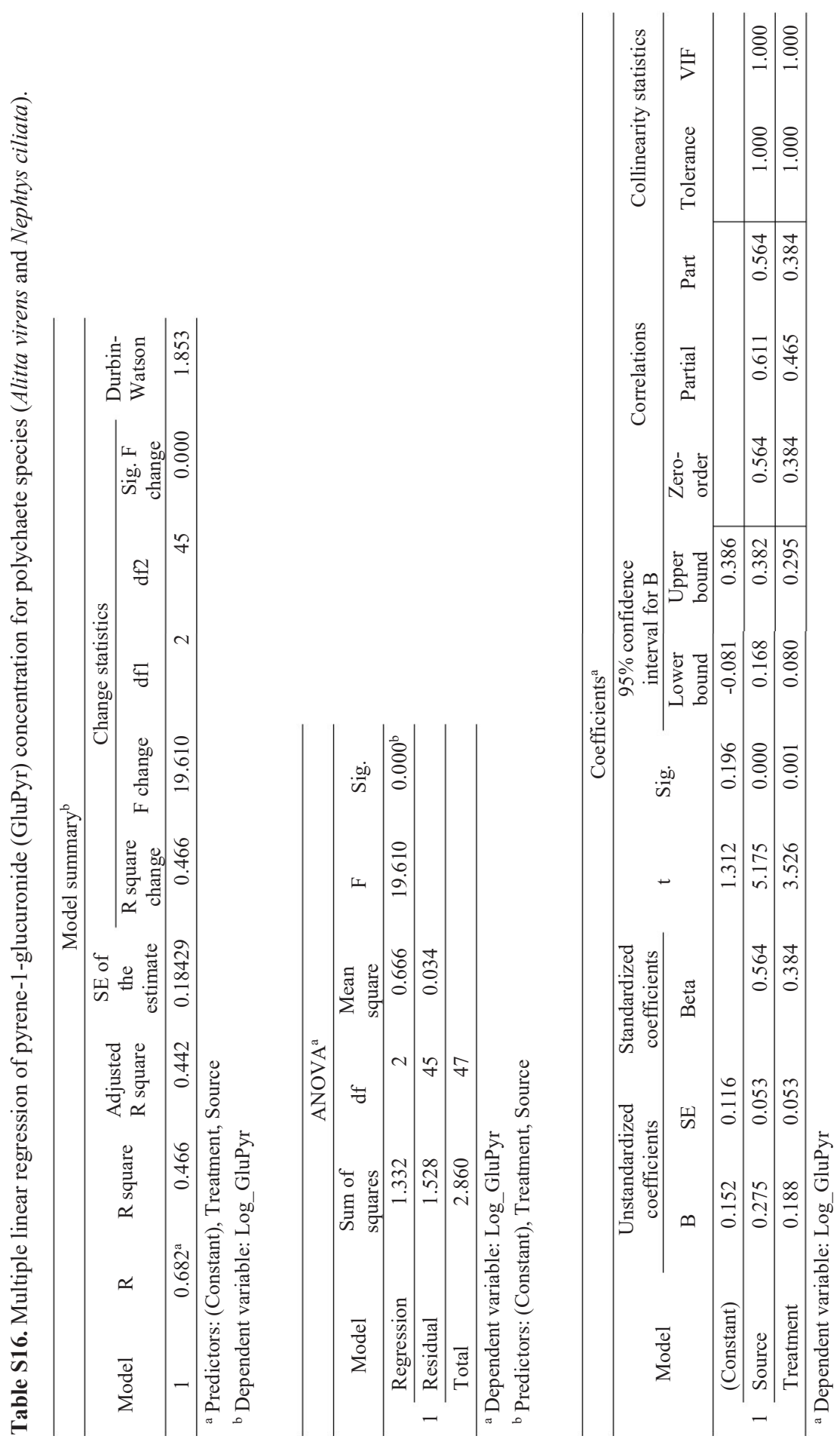


\section{Chapter 4}
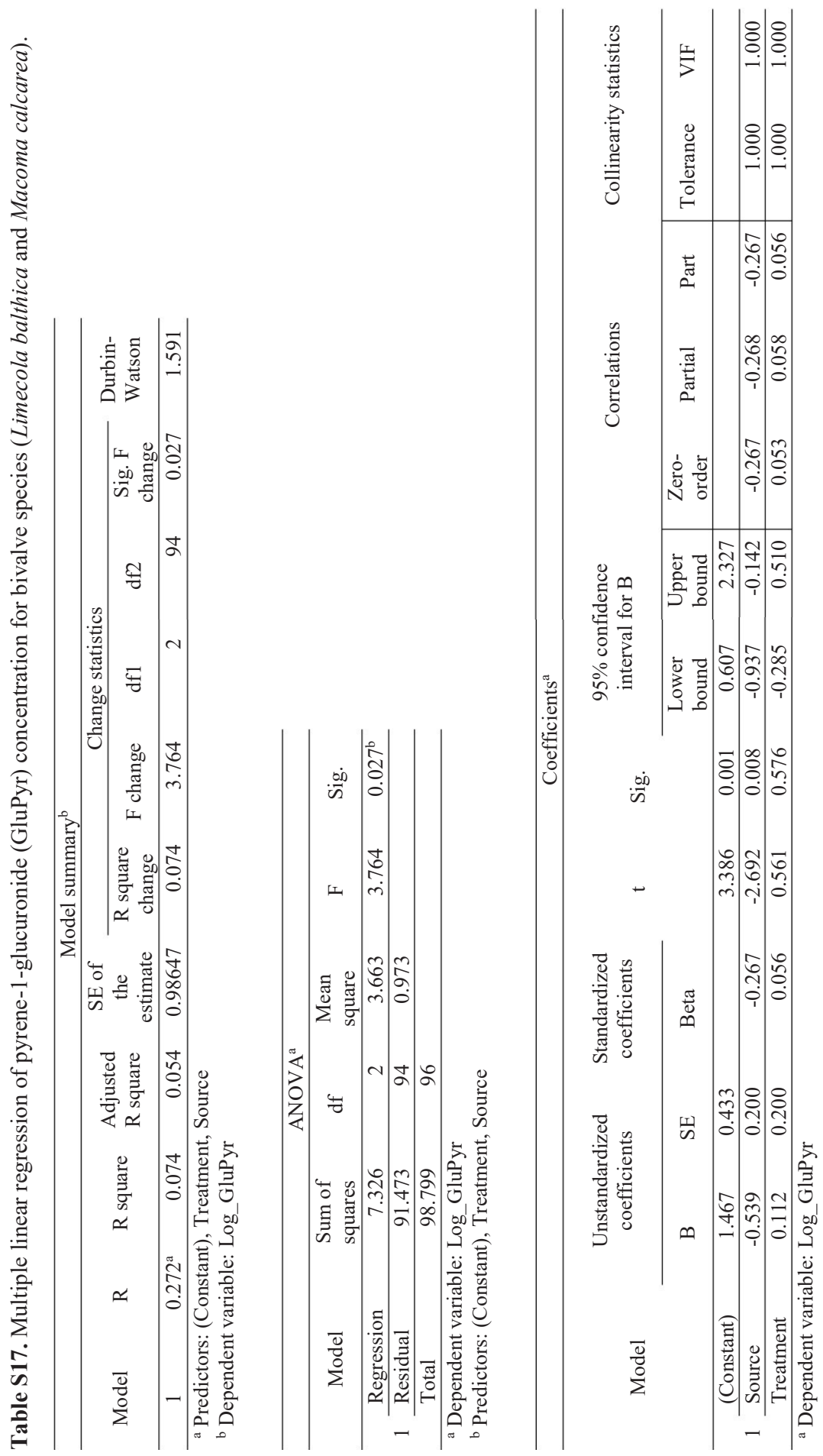

146 
Chapter 4
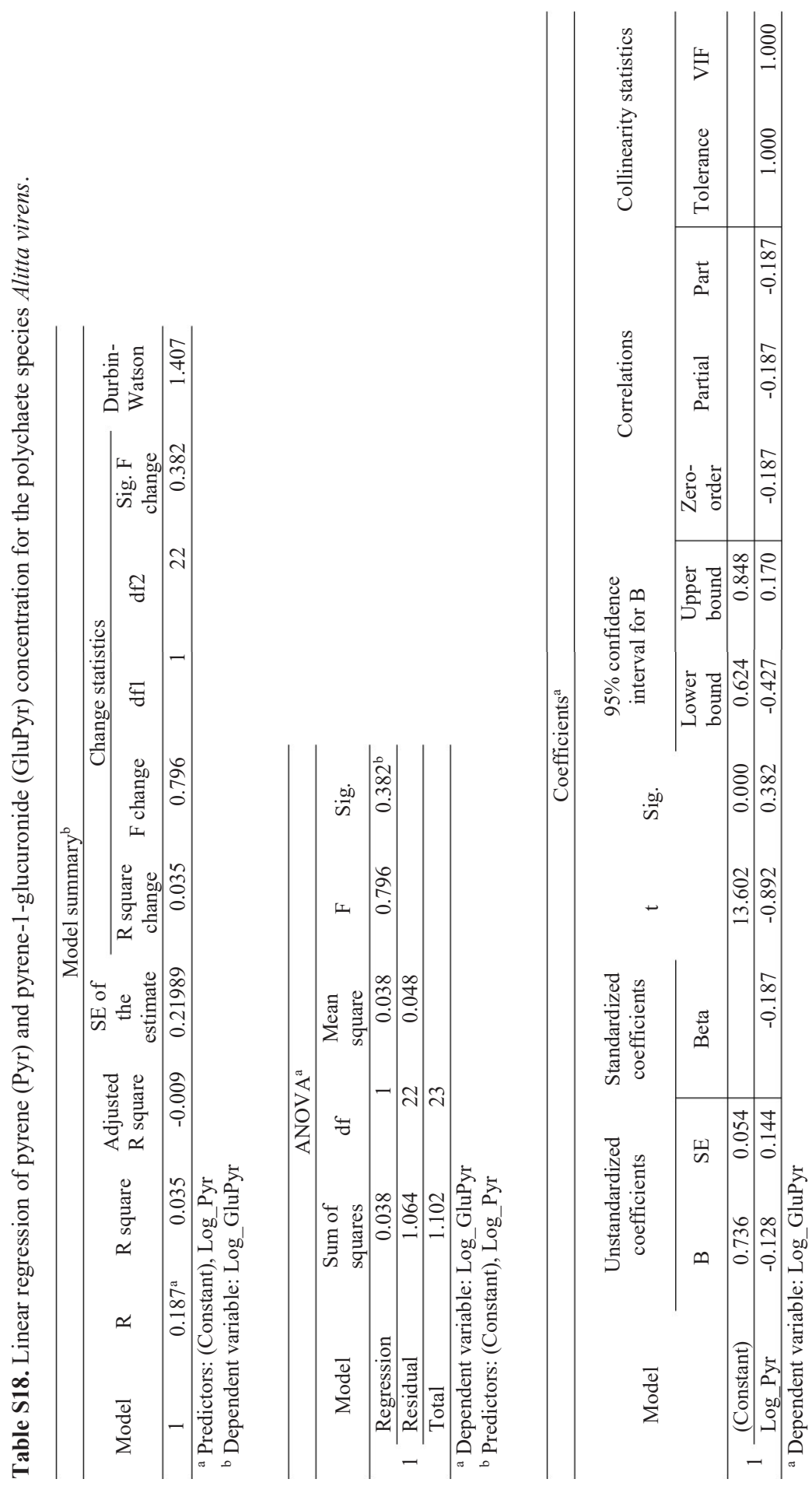


\section{Chapter 4}
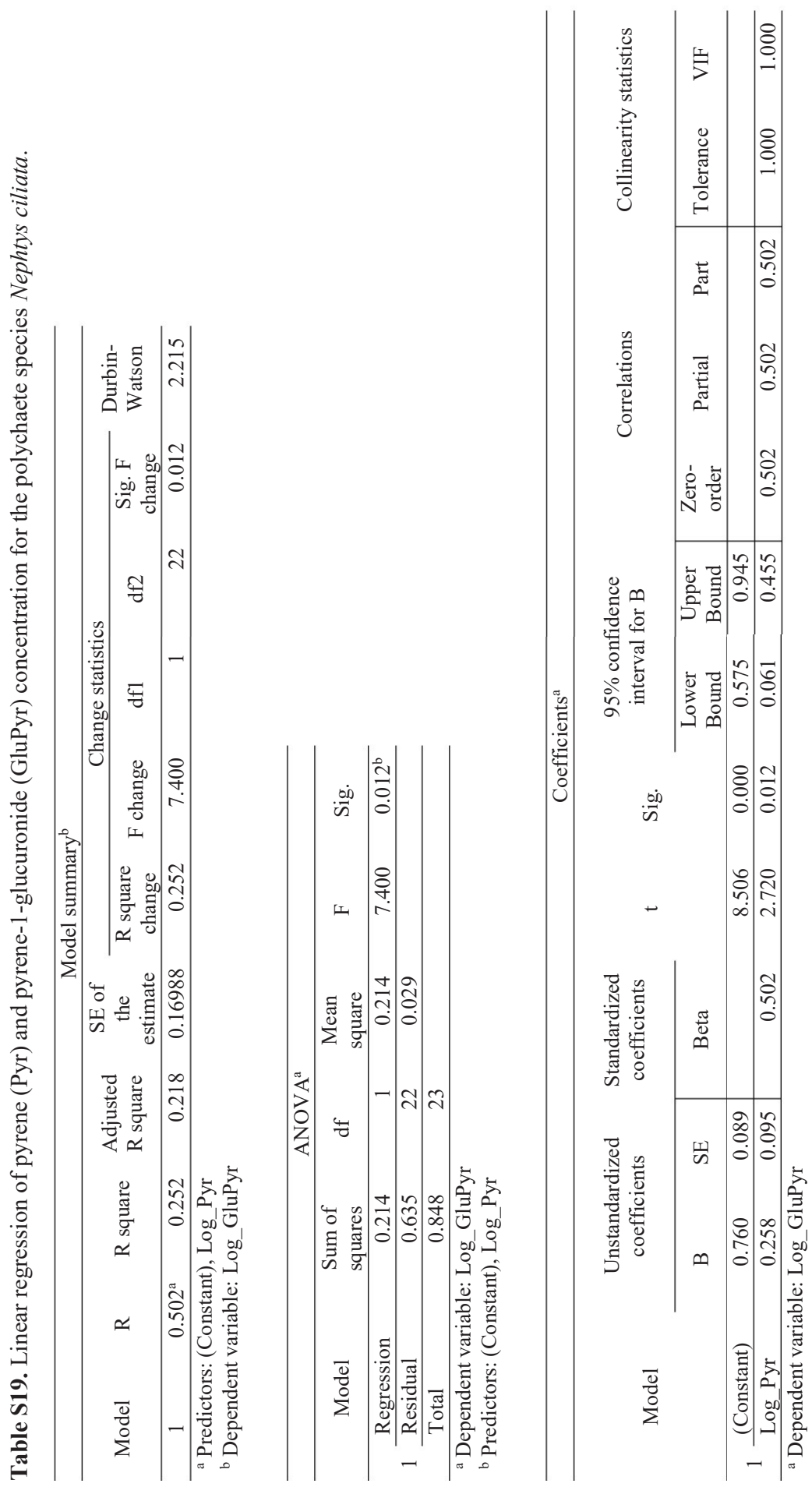

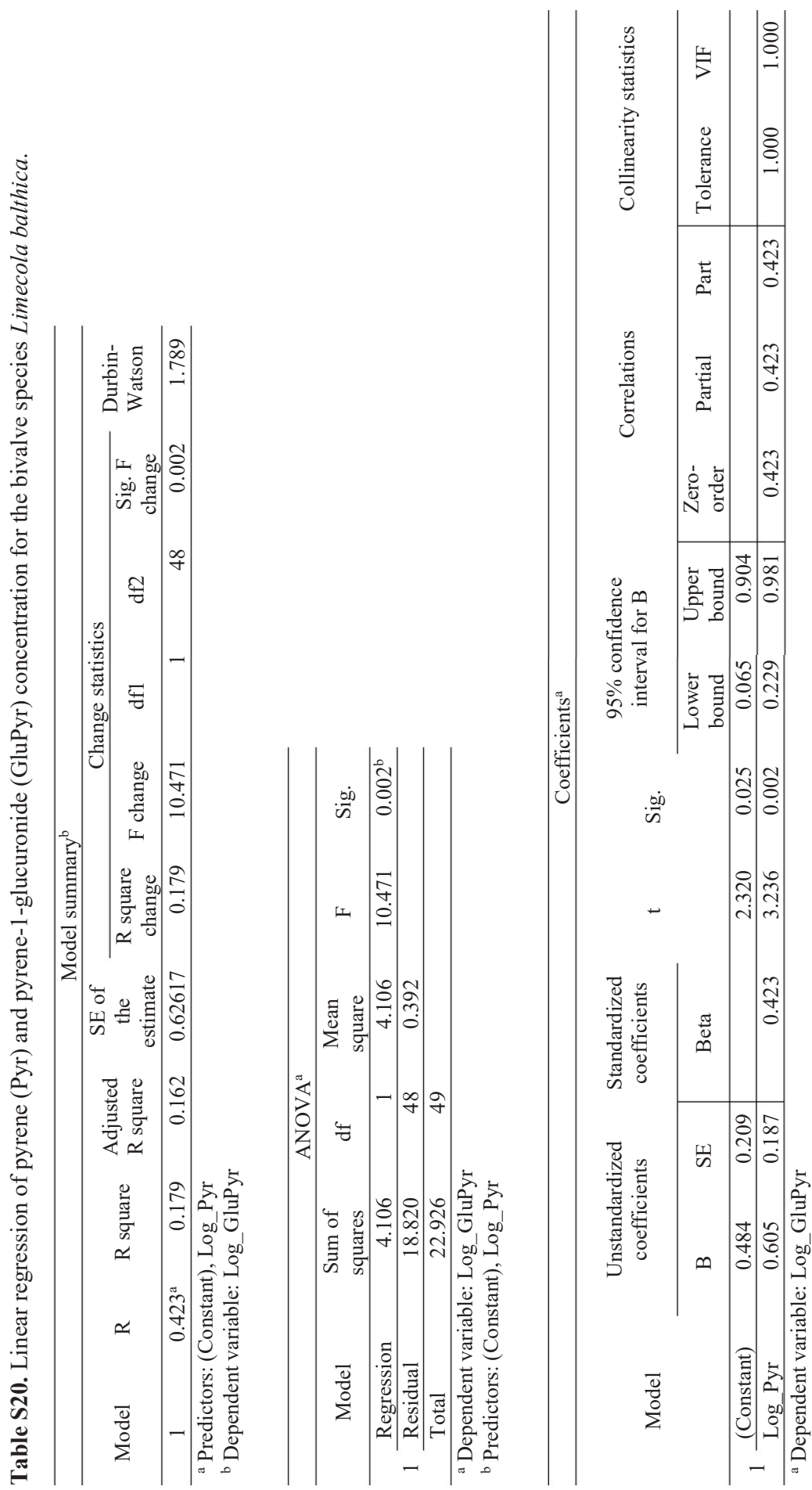


\section{Chapter 4}
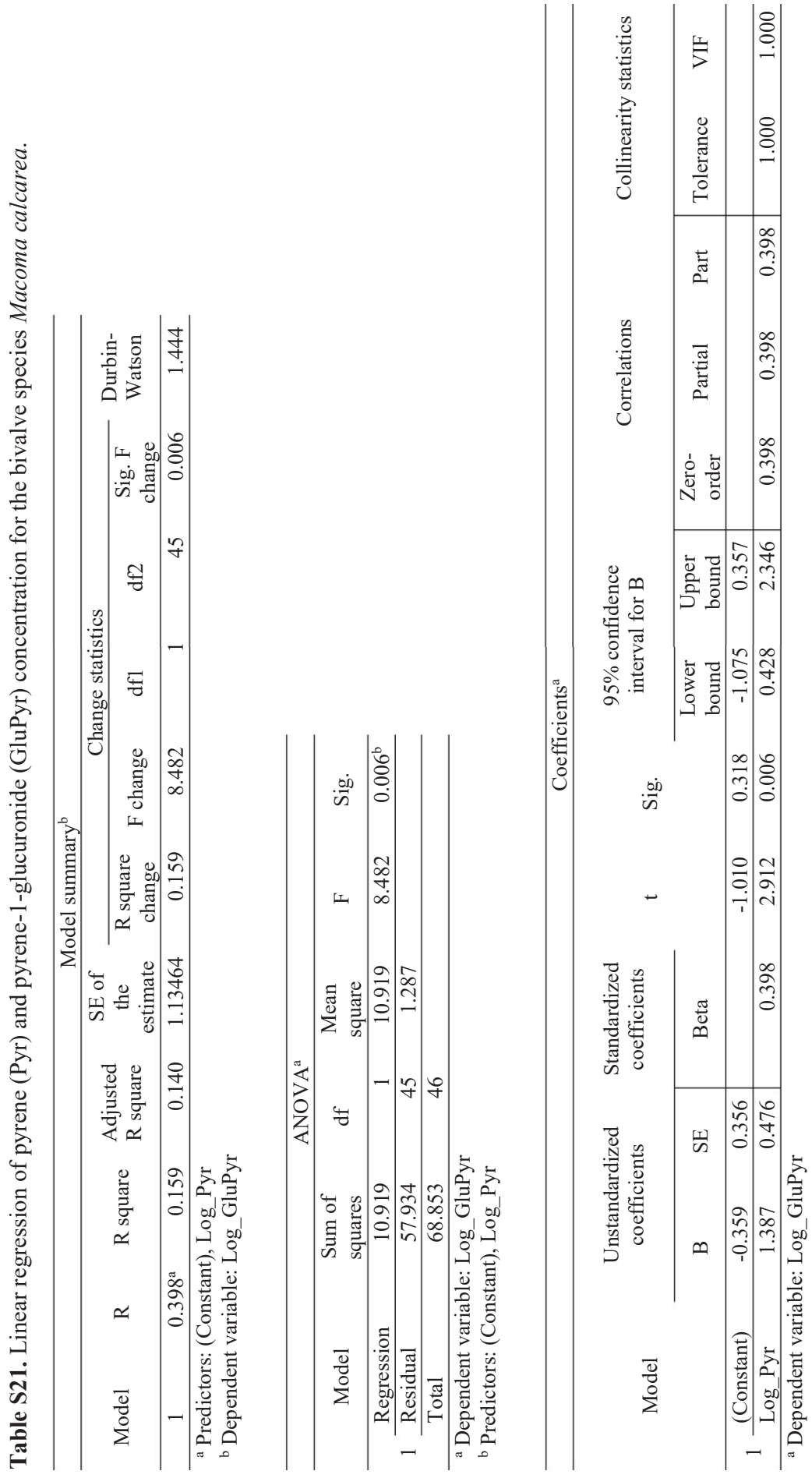

150 


\section{Avoidance tests as a tool to detect sublethal effects of oil- impacted sediments}

Ariadna S. Szczybelski, Tineke Kam pen, Joris Vıom ans, EdwinT.H.M. Peeters, Martine J. van den Heuvel-Greve, Nico W. van den Brink \&

Albert A. Koelm ans

Based on:

Szczybelski, A.S., T. Kam pen, J.Vrom ans, E.T.H.M. Peeters, M.J. van den Heuvel-Greve, N.W. van den Brink \& A.A. Koelm ans (2018)Avoidance tests as a tool to detect sublethal effects of oil-im pacted sedim ents Environmental Toxicology and Chemistry 37(6), 1757-1766. 


\title{
Chapter 5
}

\begin{abstract}
Currently, risk assessm ent for oil contam ination does not consider behavioral responses of benthos to oil toxicity. Avoidance of oil-contam inated sedim ent by benthic am phipods, however, $\mathrm{m}$ ay be ahighly sensitive endpoint for sublethal effects of com $\mathrm{m}$ only used distillate fuels. In the present study, the avoidance behavior of tem perate freshwater (Gammarus pulex) and $\mathrm{m}$ aine (Gammarus locusta) am phipods is tested, allowing them to choose between a reference sedim ent and a Distillate Marine grade A (DMA) oilspiked sedim ent. Avoidance of DMA-spiked sedim ent at $1000 \mathrm{~m} \mathrm{~g} / \mathrm{kg}$ (dry weight) was significant within total exposure tim e (96 h) in G. pulex and within the first $72 \mathrm{~h}$ in G. locusta in one of two tests. Absence of DMA avoidance at lower concentrations ( $\leq 250 \mathrm{~m} \mathrm{~g} / \mathrm{kg}$ dry weight) indicates that testspecies can only detect DMA above these concentrations. However, sensitivity to oil $\mathrm{m}$ ay vary according to the phenology and physiological conditions of the populations involved, such as the species tem perature tolerance and reproductive stage. The results suggest that avoidance tests $m$ ay be used as an alternative to traditional chronic toxicity tests provided that a causal link between avoidance and long-term effects can be established.
\end{abstract}




\section{Introduction}

Increasing global offshore oil and gas (O\& G) production, oil transportation and shipping entail higher risks of accidental oil spills which are known to cause severe environm ental im pacts. The assessm ent of potential environm ental consequences should be based on the relationship between the extent of oil exposure and the sensitivity of $m$ arine species and their habitats. Following a spill, the com position of oil and its toxicity will m ostly vary according to the tim ing and $m$ agnitude of oil spreading and evaporation on sea surface[293]. In this process, the $\mathrm{m}$ ore water soluble and bioavailable fraction of oil volatilizes or degrades in the first several days, while the $m$ ore hydrophobic oil com ponents will be deposited to the seafloor where degradation is $\mathrm{m}$ uch slower[294]. Exceptions $\mathrm{m}$ ay apply to polar regions where the presence of ice can greatly reduce oil spreading and low tem peratures $m$ ay lower oil hydrocarbons partitioning and depletion rates [51]. Thus, the identification of biological features affecting oil exposure in local benthic organism $\mathrm{s} m$ ay help to better characterize the sensitivity of environm ental receptors such as shoreline habitats[295,296].

Monitoring of environm ental stress resulting from $O \& G$ activities can be based on assayshtat use behavioral endpoints, like m ovem ent ability[105,297]. Anim al behavior integrates biochem ical and physiological processes in response to chem ical stressors. As such it is expected to be $m$ ore sensitive thana lethal response [298], provided that an organism is able to sense a toxicant via olfaction or taste [299], and it $\mathrm{m}$ ay potentially reflect changes at a population level [97]. In a natural environm ent, $m$ obile species $m$ ay be able to $m$ ove away from oilcontam inated sites before the oil can exert its toxic effects. In som e cases, such responses $\mathrm{m}$ ay be absent. For exam ple, in case of chronic toxicity[300] or when the individuals' energy allocation to locomotion, and thus avoidance, is attenuated [301-303].

Previous research addressed avoidance behavior in laboratory assays, studying spatial avoidance of either water or sedim ent containing different chem icals (sum m arised bAraújo et al. [96]). Am phipods have been used in avoidance assays since they are equipped with a sensory system [98-101]. Studies on the avoidance behavior of oil-contam inated sedim ent by benthic organism s are lim ited and restricted to the m arine environme [99,304-306]. In these studies, generally a bi-com partm ented system container was used to test the ability of am phipods to discern between a clean and a contam inated sedim ent. However, a preference for the clean sedim ent or avoidance of the contam inated sedim ent is not always evident, because for instance exposure to sublethal concentrations of oil $\mathrm{m}$ ay lead to contrasting 


\section{Chapter 5}

sensitivities among different groups of amphipods or 'attractive' odours may be masked by oil $[108,109]$. The effect of tim e is generally not considered or lim ited to a single tim e point per exposure day, which elim inates the possibility of identifying likely experim ental biases such as a (pre-)adaptation to the chem ical cue[100].

Spatial avoidance can be divided into active and passive avoidance [96], each occurring under the changing physical state of chem icals over exposure time. Active avoidance or 'escape' response relates to the ability of an organism to detect a chem ical and to $m$ ove to a lesser contaminated area, whereas passive avoidance or 'drift' response will occur when water flow is responsible for the organism dsplacem ent. In a bicom partm ented static system, am phipods will display active spatial avoidance provided that no other physical disturbances are present (e.g., sand, seaweed). The effect of tim e on the am phipods distribution $\mathrm{m}$ ay help to predict possible interactions between avoidance and their physiological susceptibility to oil [307] as well as their long-term im plication§[308].

The objective of the present study is to evaluate the potential of sedim ent avoidance tests using benthic am phipods as a m onitoring tool for oil spill im pact assessm ent. Prior to testing, oil was $m$ ixed with the sedim ent. We tested the avoidance behavior of a freshwater am phipod Gammarus pulex and a m arine benthic am phipodGammarus locusta as m odel invertebrate species, to sedim ent spiked with a com m only used distillate fuel oil (i.e., Distillate Marine grade A [DMA]) during a 96-h test period. DMA oil is widely used as fuel in m idsized to larger ships such as large inland vessels, large cutters and coasters [309], and is often used in oil toxicity studies $[43,46]$. These species were deployed as a first step to develop ecologically relevant tests for oil im pact assessm ent.

\section{Materials and Methods}

\subsection{Test organisms}

Freshwater experiment (FW). Following De Lange et al. [100], G. pulex (Linnaeus, 1758) adult individuals $(9.7 \pm 1.8 \mathrm{~m} \mathrm{~m})$ were collected from a nospolluted freshwater stream near Heelsum (The Netherlands, 51 $58^{\prime} 40.3^{\prime \prime}$ N, 545'27.8"E) on 13 March 2014. Anim als were transported to the laboratory in plastic buckets with water from the collection stream and acclim atized in a water bath during $10 \mathrm{~d}\left(15 \pm 1^{\circ} \mathrm{C}\right)$. Since anim als were collected in winter and seasonal effects $\mathrm{m}$ ay influence tolerance to toxicants exposure[310], the tem perature and 
duration of acclim atization were chosen according to the tem perature range used by sim ilar avoidance studies $[99,100]$ and studies on effects of tem perature on G. pulex physiology [311,312]. During acclim atization, oxygenated copperfree tap water was used and anim als were fed unconditioned poplar leaves ad libitum . Prior to their use, poplar leaves were leached in tap water to rem ove active leachable substances, and dried.

Water quality variables such as tem perature, dissolved oxygen, electric conductivity and $\mathrm{pH}$ were m easured regularly during acclim atization (Table S1).

Marine water experiments (MW1 and MW2). G. locusta (Linnaeus, 1758) individuals were collected over $4 \mathrm{~d}$ in the Oosterschelde estuary (The Netherlands, $51^{\circ} 32^{\prime} 41.3^{\prime \prime} \mathrm{N}, 3^{\circ} 55^{\prime} 30.0^{\prime \prime} \mathrm{E}$ ) on 24 to 25 June 2016 and 25 to 26 July 2016, hereafter MW1 and MW2 experim ents. Since G. locusta life-span and m aturity age are known to be greatly reduced by water tem perature [313], individuals of the species were collected at two different tim es during sum $m$ er in order to assess the consistency of experim ental results.Anim als were transported to the laboratory in 15 -L jerry cans with water from the collection site and acclim atized during $5 \mathrm{~d}\left(15 \pm 1{ }^{\circ} \mathrm{C}\right)$. Sea water tem perature from the collection site was $17 \pm 1^{\circ} \mathrm{C}$ in June and $21 \pm 1{ }^{\circ} \mathrm{C}$ in July. During acclim atization, anim als were kept in $18 \mathrm{~L}$ glass aquaria each of them holding approxim ately 200 to 500 individuals in $15 \mathrm{~L}$ of oxygenated artificial sea water (ASW) (40 g/L, Pro Reef Salt, Colom bo B.V.). A few stones from the collection site were also placed inside each aquarium for com fort of the test anim als and anim als were fed fish food tabs (Tetra Waferm ix) ad libitum .

\subsection{Sediment spiking}

For the freshwater experim ent, sedim ent was collected from a pond at Wageningen University cam pus. Sedim ent was sieved with a $2-\mathrm{m} \mathrm{m}$ sieve ( $83 \%$ dry wt. $0.88 \%$ organic $\mathrm{m}$ atter) and spiked with DMA to obtain four different nom inal concentrations: 0 (Control), 50 (Low), 250 (Medium ) and 1000 (High) m g DMA/kg sedim ent (dry wt.). DMA oil was supplied by Gulf Oil (Nigtevecht, the Netherlands) and was the sam e as used in our earlier studies, where also chem ical characteristics are provided[43,46]. Nom inal DMA concentrations were chosen to $m$ atch fieldrelevant concentrations $[314,315]$ and to $m$ atch the range of oil concentrations for which PAH sedim entwater partition coefficients $\left(\mathrm{K}_{\mathrm{d}}\right)$ are generally independent of oil concentration (i.e., $100-1000 \mathrm{~m} \mathrm{~g} / \mathrm{kgdry}$ wt. [46]). This was observed after a 2 year weathering process of oil-spiked sedim ent, although in som e cases (i.e., 3ring PAHs) $\mathrm{K}_{d}$ 


\section{Chapter 5}

values were increased after weathering [46]. A relative stability of 2- to 3-ring PAHs in weathered surface oil [316] and in slick oil spiked to sedim ent[317], as well as their sublethal effects on benthic biota exposed at $1.7 \mathrm{~m} \mathrm{~g} / \mathrm{kg}$ (dry wt.) $\left(\sum_{50} \mathrm{PAH}=2.6 \mathrm{~m} \mathrm{~g} / \mathrm{kgdry} w \mathrm{wt}\right.$. $)$ or $\mathrm{m}$ ore, have been reported in literature[317,318]. Therefore, concentrations of 3-ring PAHs (e.g., phenanthrene, anthracene) in the high DMA treatm ent were considered sublethal $(\sim 1$ $\mathrm{m} \mathrm{g} / \mathrm{kgdry}$ wt.) assum ing a fair sim ilarity in weathering conditions betweenJonker et al. [43] and the present study.

For each sedim ent treatm ent containing DMAspiked sedim ent (50- $1000 \mathrm{~m} \mathrm{~g} / \mathrm{kgdry}$ wt.), the required volum e of DMA was divided into three batches to $m$ inim izthe adsorption of DMA onto the barrel walls and its evaporation during stirring. Sedim ent was continuously stirred while each of the DMA batches was added drop by drop from a glass pipette. Once each oil batch was added, sedim ent stirring continued for abaut $5 \mathrm{~m}$ in and allowed to rest for another 5 $\mathrm{m}$ in before addition of following batch under the sam e procedure. After spiking, each sedim ent treatm ent was $\mathrm{m}$ ixed on a roller bank during apporim ately $22 \mathrm{~h}$ and stored $\left(7 \pm 1^{\circ} \mathrm{C}\right)$ for 4 weeks before use. For the control treatm ent, sedim ent was stirred and $m$ ixed in the sam e way without the addition of oil, and stored.

For the $\mathrm{m}$ arine $G$. locusta experim ents, sedim ent was collected at the anim als collection site during low tide. Sedim ent was sieved ( $86 \%$ dry wt., $0.82 \%$ organic carbon) and spiked with DMA following the sam e procedure as in the freshwater experim ent. After spiking, each sedim ent treatm ent was $\mathrm{m}$ ixed on a roller bank during approxim ate $4 \mathrm{~h}$ and stored $\left(4 \pm 1{ }^{\circ} \mathrm{C}\right)$ for 2 to 6 weeks before use. The control sedim ent treatm ent was prepared as $m$ entioned above.

\subsection{Experimental design}

The avoidance experim ents were perform ed in glass aquaria $(20 \times 20 \mathrm{~cm})$. A glass barrier was placed in the $\mathrm{m}$ iddle of each aquarium dividing the bottom into two equal parts. One side was filled with a $2-\mathrm{cm}$ layer of control sedim ent and the other side with a $2 \mathrm{~cm}$ layer of control or spiked sedim ent. In each experim ent, $800 \mathrm{~m} \mathrm{~L}$ of either coppefree tap water or ASW was gently added to each aquarium in order to avoid sedim ent disturbance, afer which the system $\mathrm{s}$ were allowed to stabilise for $24 \mathrm{~h}$. The freshwater G. pulex experim ent was perform ed at Wageningen University laboratories, whereas the $\mathrm{m}$ arine experim ents with $G$. locusta were perform ed at the $\mathrm{m}$ arine research laboratories of WageningenMarine Research (Yerseke, the Netherlands). In the freshwater experim ent, the aquaria were random ly distributed within a 


\section{Chapter 5}

water bath $\left(15 \pm 1{ }^{\circ} \mathrm{C}\right)$, whereas for $\mathrm{m}$ arine water experim ents the aquaria were random ly placed on a table located inside a clim ate room $\left(5 \pm 1^{\circ} \mathrm{C}\right)$. Once the system $\mathrm{s}$ were stabilised, another $800 \mathrm{~m} \mathrm{~L}$ of either copperfree tap water or ASW was carefully added, after which the system $\mathrm{s}$ were allowed to stabilise for $3 \mathrm{~d}$. Five replicates (aquaria; $n=5$ ) were used for each of the four sedim ent tream ents (control, low, m edium and high DMA concentration) during each experim ent.

Prior to the addition of the anim als, the water layer was partially renewed. A volum e of 800 $\mathrm{m} \mathrm{L}$ of the system water was pum ped out of each aquarium and renewed with $800 \mathrm{~m} \mathrm{~L}$ olfean copper-free tap water or ASW, respectively. This was done to $m$ inim ize the concentration of water soluble DMA toxicants in the water colum $n$ with respect to the concentration in the spiked sedim ent layer at start. The glass barriers were carefully rem oed and 20 individuals were added in the m iddle of each aquarium to ensure that the starting position did not influence the experim ent outcom $\mathrm{e} 100]$. Anim als were kept under a $16 \mathrm{~h}$ light: $8 \mathrm{~h}$ dark red light cycle since Gammarus spp. usually becom e photonegative when they reach an adult size [319]. However, dim light was needed for $\mathrm{m}$ aintenance and to facilitate the visual recording of the anim al distribution.

\subsection{Endpoints}

During the rem oval of barriers, som e m ixing of control and spiked sedim ent could not be prevented at surface level in the $\mathrm{m}$ iddle area. Therefore, the $\mathrm{m}$ iddle area was excluded from the statistical analyses. Each system sedim ent surface was divided into three areas: control (37.5\% of the surface), $\mathrm{m}$ iddle (25\%) and spiked (37.5\%). The num ber of indviduals staying for at least 5 to 6 consecutive seconds within the control or spiked area during an observation bout was recorded as 'control' or 'spiked', respectively. Recordings took place during a 96-h period allowing an estim ation of the effect of DMA concentration (treatm ent) onGammarus spp. avoidance of the DMA-spiked area over time (day). Only the results of the 'control' scores of each replicate were used to test whether their relative distribution at the control section was higher than $37.5 \%$, in which case the null hypothesis was rejected and avoidance of the spiked area was considered occurred. Water quality variables were $\mathrm{m}$ easured at the beginning of each recording day in three experim ental control replicate aquaria without anim als during the first $\mathrm{m}$ arinœxperim ent (Table S2) and in each experim ental replicate at the end (Table S3) of both $\mathrm{m}$ arine experim ents. 


\section{Chapter 5}

\subsection{Data analyses}

Logistic regression within the fram ework of Generalized Linear Mixed Models (GLMM) was used to analyse the relationship between the num ber of individuals in the control section treated as repeated $m$ easures for each aquarium (experim ental unit) and the effect of treatm ent, day and their respective interaction as effect builders. GLMM statistical tests provide a $\mathrm{m}$ ore flexible approachthan other non-param etric tests for analysing non-norm al data when random effects are present. Only observations obtained from the second to the fourth experim ental day were used since they include an equal num ber of recordings per day and handling of the anim als could also have induced stress on the first day. Observations were collected 3 tim es per day for each aquarium and treatm ent in the freshwater experim ent, that is 180 observations in total; and 7 tim es per day for each aquarium and treatm ent in the $\mathrm{m}$ arine experim ents, $\mathrm{m}$ aking a total of 420 observations for each experim ent. Observations were assum ed to be Poisson distributed following the repeated recording of a single event (i.e., 'control' score takes integer values between 0 and 20) and a pairwise contrast am ong treatm ents and recording days was chosen in order to calculate the estim ated $m$ eans. The significance level of an overall statistical com parison was set at $p \leq 0.05$, while for pairwise com parisons the least significant difference correctionwas applied. All statistical calculations were perform ed using SPSS version 22.

\section{Results and Discussion}

\subsection{Freshwater Gam m arus pulexavoidance}

G. pulex avoidance was significantly and consistently higher in the high DMA treatm ent than in the control and low treatm ent (day 2 to 4) (Figure 1; Tables S4S6). G. pulex avoidance behavior in the m edium DMA treatm ent was significantly different from that in the control, low and high treatm ent on day 2, after which an apparent attenuation of avoidance was observed (Figure 1). No m ortality was observed within the total test duration (4 d) throughout the range of nom inal DMA concentrations used (0- $1000 \mathrm{~m} \mathrm{g/kgdry} \mathrm{wt.).}$ 


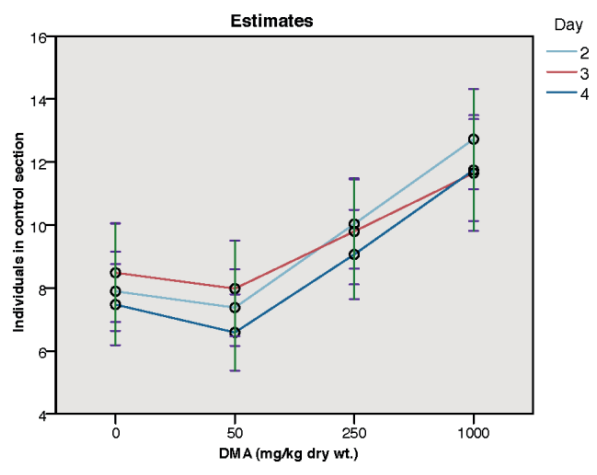

Pairwise contrasts
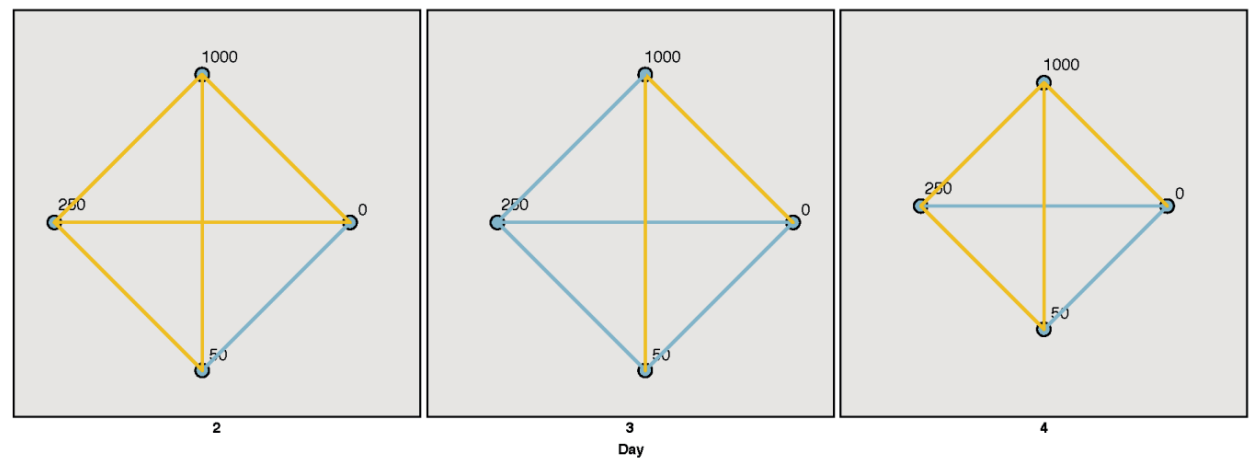

Figure 1. Generalized linear $m$ ixed $m$ odels avoidance estim ated $m$ eans with confidence intervals and 'treatm ent× day' pairwise contrasts for Gammarus pulex exposed to Distillate Marine grade A (DMA) oil (FW experim ent). Avoidance is expressed as num ber of individuals staying for at least 5 to 6 consecutive seconds within the control section per DMA treatm ent $(0-1000 \mathrm{~m} \mathrm{~g} / \mathrm{kgdry} w t$.$) and day (2-4)$. Significant contrasts $(p \leq 0.05)$ are shaded gold.

A consistent avoidance response of G. pulex exposed to the high DMA treatm ent from day 2 to 4 could be explained by a com bined result of exposure to a high DMA concentration and to the species upper therm al tolerance $\lim$ it (i.e., $15^{\circ} \mathrm{C}$ ) in northern populations of G. pulex [311]. According to the 'oxygen- and capacity-lim ited therm al tolerance' m odel, failure of oxygen transport system $\mathrm{s}$ to $\mathrm{m}$ atch body oxygen dem and dictates therm al tolæmce [320]. An increase in the oxygen (energy) dem and of $G$. pulex winter populations $\left(\sim 5^{\circ} \mathrm{C}\right.$ at which the organism s were sam pled) a the exposure tem perature $\left(15^{\circ} \mathrm{C}\right)$ is expected to be $\mathrm{m}$ et by an increase in their ventilation rate $[321,322]$. An increase in ventilation $m$ ay facilitate the detection and transm ission of chem ial cues [323] and possibly triggered avoidance in $G$. pulex exposed to the high DMA treatm ent fiom the first day of exposure. Another 


\section{Chapter 5}

consequence of the $\mathrm{m}$ aintenance of $G$. pulex within its optim al therm al window can be that glycogen reserves, which is the m ain energy fuel for oxygen deficiency and sustained activity, are relatively stable provided that food is not lim iting[324]. The m obilization of these energy stores would allow G. pulex to actively avoid DMA-spiked sedim ent and to counterbalance the stress produced by DMA exposure at the experim ent start.

DMA exposure in the low and m edium DMA treatm ents was m ost probably too low to elicat continuous avoidance by G. pulex. The observed differences in DMA avoidance response between the low and m edium treatm ent expose $\mathbb{G}$. pulex on day 2 and 4 of exposure were m ost likely a reflection of within treatm ent variability (Figure 1 Table S4). Variability in the actual exposure to DMA and avoidance response of G. pulex exposed to the m edium DMA treatm ent $\mathrm{m}$ ay be underlain by intraspecific differences inG. pulex m olecular response to starvation or reproduction $[311,325]$ am ong other factors.

In sum $\mathrm{m}$ ary,G. pulex active avoidance of DMA-spiked sedim ent was significant and continuous over exposure tim e (day 2 to 4) at a DMA concentration of $1000 \mathrm{~m} \mathrm{~g} / \mathrm{kg}$ (rry wt.), and som etim es at $250 \mathrm{~m} \mathrm{~g} / \mathrm{kg}$ (dry w). Since no $\mathrm{m}$ otality was observed within the total test duration $(4 \mathrm{~d})$ in none of the treatm ents, it was assum ed that no deleterious effects were caused by DMA on the sensory system of individuals.

\subsection{Marine Gam m arus locustavoidance}

G. locusta avoidance during the first $\mathrm{m}$ arine experim ent was significantly higher in the high DMA treatm ent com pared to the control, the low and m edium DMA treatm ents from day 2 to 3 (Figure 2), whereas in the second $\mathrm{m}$ arine experim ent no effect of treatm ent or day olG. locusta avoidance was found (Figure 3). G. locusta avoidance was also significantly higher in individuals exposed to the high DMA treatm ent in the first com pared to the second $\mathrm{m}$ arine experim ent from day 2 to 3 (Tables S13and S14). No m ortality was observed within the total test duration $(4 \mathrm{~d})$ throughout the range of nom inal DMA concentrations used $(0-1000$ $\mathrm{m}$ g/kgdry wt.). 


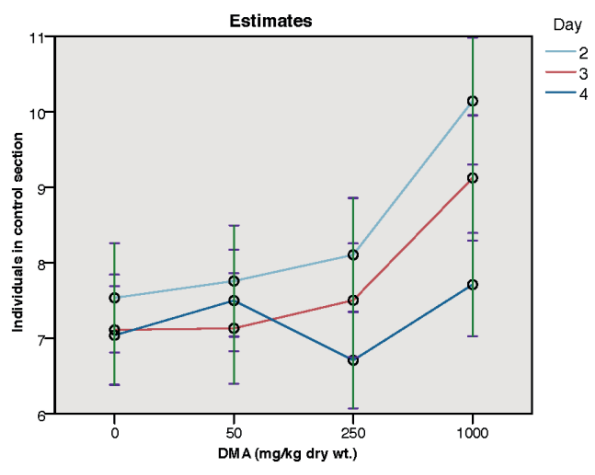

Pairwise contrasts
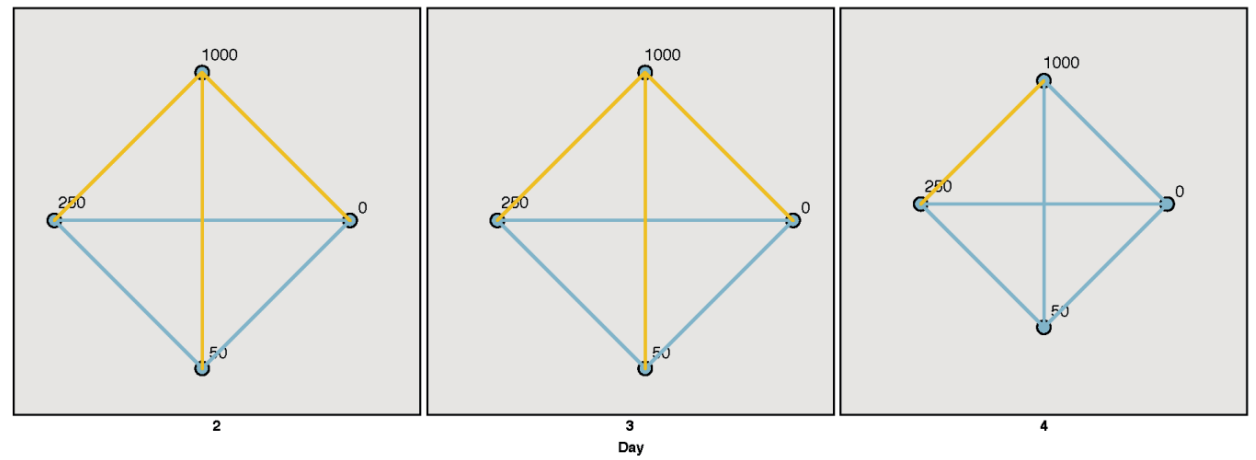

Figure 2. Generalized linear $m$ ixed $m$ odels avoidance estim ated $m$ eans with confidence intervals and 'treatm ent $\times$ day' pairwise contrasts for Gammarus locusta exposed to Distillate Marine grade A (DMA) oil (MW1 experim ent). Avoidance is expressed as num ber of individuals staying for at least 5 to 6 consecutive seconds within the control section per DMA treatm ent $(0-1000 \mathrm{~m} \mathrm{~g} / \mathrm{kgdry} w t$.$) and day (2-4)$. Significant contrasts $(p \leq 0.05)$ are shaded gold. 


\section{Chapter 5}

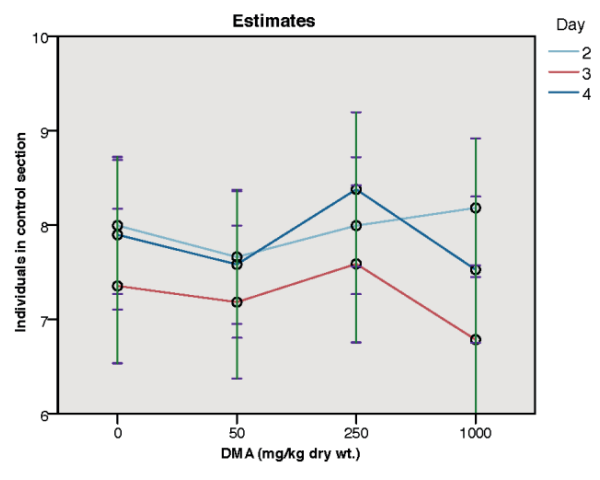

Pairwise contrasts
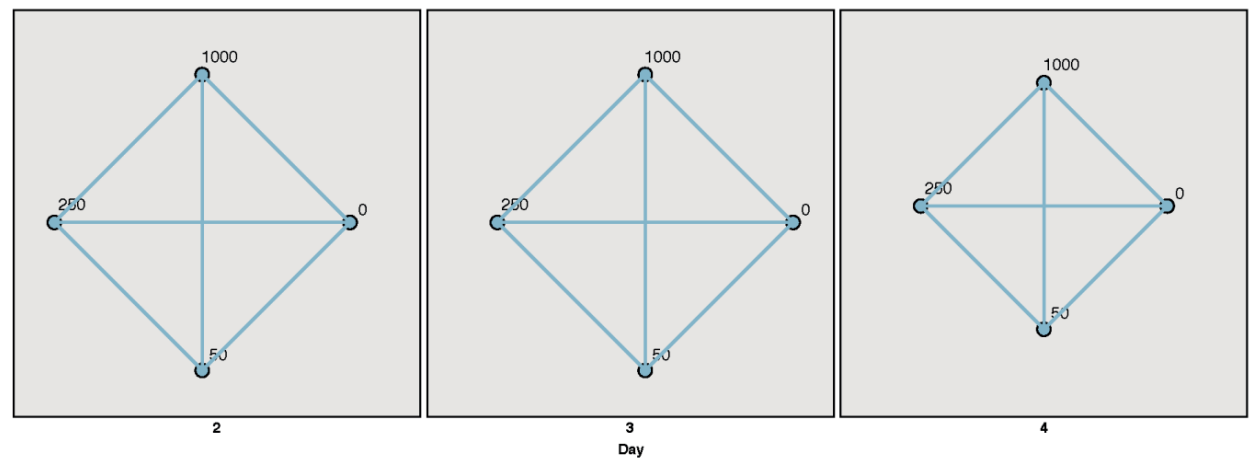

Figure 3. Generalized linear $m$ ixed $m$ odels avoidance estim ated $m$ eans with confidence intervals and 'treatm ent× day' pairwise contrasts for Gammarus locusta exposed to Distillate Marine grade A (DMA) oil (MW2 experim ent). Avoidance is expressed as num ber of individuals staying for at least 5 to 6 consecutive seconds within the control section per DMA treatm ent $(0-1000 \mathrm{mg}$ /kgdry wt.) and day $(2-4)$. Significant contrasts $(p \leq 0.05)$ are shaded gold.

In an experim ent perform ed byHellou et al. [99], the preference for reference sedim ent could also not be clearly elucidated in the $\mathrm{m}$ arine am phipodCorophium volutator exposed to freshly diesel oil-spiked sedim ent $(>0.01 \%)$. As explained by the authors, a high variation in the response between exposure replicates and high $\mathrm{m}$ ortality of $C$. volutator were caused by a narcotic effect of diesel oil. Besides avoidance behavior, re-em ergence andfailure to burrow did not follow a concentration-related response in C. volutator exposed to sedim ent spiked with artificially weathered crude oil at 220 to $880 \mathrm{~m} \mathrm{~g} / \mathrm{kg}$ (dry wt.) [326]. In our experim ents, the highest two DMA concentrations were $0.02 \%$ and $0.1 \%$, respectively, but neither m ortality nor narcotization were observed in G. locusta. As in C. volutator exam ple[326], G. 
locusta avoidance behavior did not correlate with DMA concentration $(50-1000 \mathrm{~m} \mathrm{~g} / \mathrm{kgdry}$ wt.) over exposure tim e (i.e., day 2 to 4 ).

Although the cause of the difference in $G$. locusta avoidance behavior between the first and second experim ents is not known, this $\mathrm{m}$ ay be linked todifferences in life stage-related factors such as body size [327], lipid content or m aturity stage[99,313] between the two experim ents. Since body size and structural ( $\mathrm{m}$ em brane) lipid content $\mathrm{m}$ ay influence the chem ical exchange at body surface, changes in these variables $\mathrm{m}$ ay be reflected in differences in the apparent sensitivity to DMA and avoidance between sum $\mathrm{m}$ er cohorts. Variability in body size and structural lipid content [328] $\mathrm{m}$ ay be further increased by a reduction in the lifespan of $G$. locusta above $15^{\circ} \mathrm{C}$ [313], the $\mathrm{m}$ axim um expression of which can be found am ong sum $\mathrm{m}$ er cohorts. A G. locusta generational succession was observed between June and July by Kolding and Fenchel [329] in the Lim fjorden strait (Denm ark) and byCosta and Costa [327] in the Sado estuary (Portugal), according to which a higher proportion of larger-sized gravid fem ales would be expected in G. locusta collected in June com pared to July.

Lack of avoidance by G. locusta exposed at 50 and $250 \mathrm{~m} \mathrm{~g} \mathrm{DMA} / \mathrm{kg}$ (dry wt.) (respectively low and $\mathrm{m}$ edium concentration) in both $\mathrm{m}$ arine experim ents could be related to a low exposure of sedim ent treatm ents as also observed in the freshwater experim ent. Both ageand sex-related differences in their oxidative stress tolerance [327,330] $\mathrm{m}$ ight account for the lack of a DMA concentration- nor tim edependent avoidance response by G. locusta [331].

\subsection{Comparison of avoidance between Gam m arus pulexand Gam m arus locusta}

Avoidance behavior of DMA-spiked sedim ent (50- $1000 \mathrm{~m} \mathrm{~g} / \mathrm{kgdry}$ wt.) could not be clearly observed in G. locusta, whereas in G. pulex avoidance was significant and continuous over exposure tim e (i.e., day 2 to 4 ) at the highest DMA concentration (Figures 4 and 5; Tables $\mathrm{S} 16$ and S17). Interpretation of avoidance results $\mathrm{m}$ ay be com plicated by differences in behavior of DMA in freshwater and $\mathrm{m}$ arine system $\mathrm{s}$ as the aqueous solubility of PAHs tends to decrease with increasing salinity [24]. Therefore, oil $\mathrm{m}$ ay have been easier detectable by Gammarus sp. in the freshwater experim ent. PAH degradation will be generally higher in freshwater than in $\mathrm{m}$ arine system $\mathrm{s}$, although degradation will be strongly influenced by oxygen availability in the sedim ent and the m olecular size of PAHs[43]. In the present study, oxygen concentration was not $\mathrm{m}$ easured in the freshwater experim ent, but lower oxygen levels were detected at the end of exposure in the second com pared to the first $m$ arine experim ent 


\section{Chapter 5}

(Table S3). This $\mathrm{m}$ ight point to a higher $\mathrm{m}$ icrobial degradation of PAHs[43] and therefore, lower DMA toxicity, in the second $\mathrm{m}$ arine experim ent than in the first $\mathrm{m}$ arine experim ent.

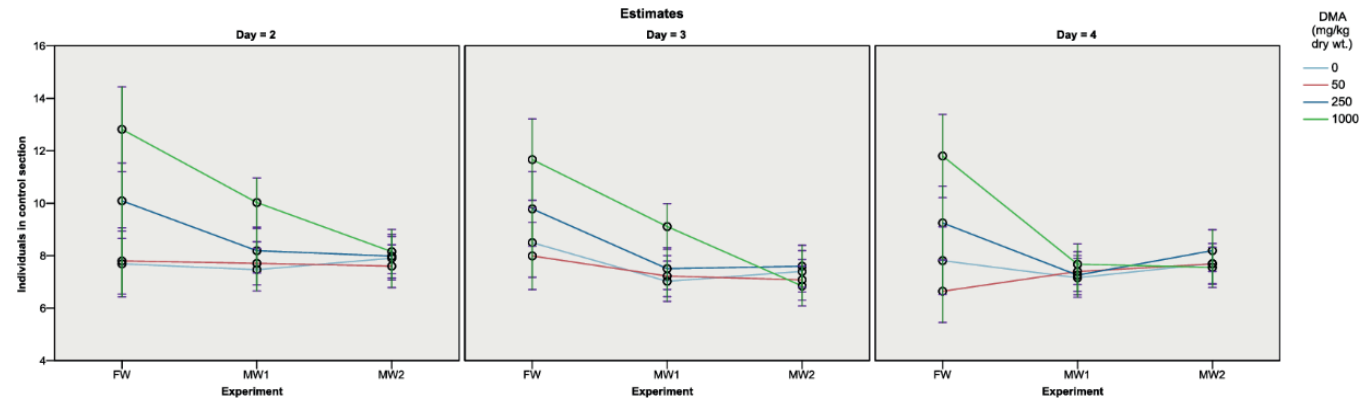

Figure 4. Generalized linear $m$ ixed $m$ odels avoidance estim ated $m$ esnwith confidence intervals for Gammarus pulex (FW experim ent) andGammarus locusta (MW1 and MW2 experim ents) exposed to Distillate Marine grade (DMA) oil. Avoidance is expressed as num ber of indviduals staying for at least 5 to 6 consecutive seconds within the control section per DMA treatm ent (0- $1000 \mathrm{~m} \mathrm{~g} / \mathrm{kgdry} w \mathrm{w}$.$) and day (2-4)$.

As indicated by previous studies [99,306], lack of reproducibility of avoidance results am ong test organism s m ay be caused by differences in their growth rate and reproductive stage.

Factors such as the individual size of G. pulex $(\sim 10 \mathrm{~m} \mathrm{~m})$ and temqrature at collection tim $\mathrm{e}$ $\left(\sim 5^{\circ} \mathrm{C}\right) \mathrm{m}$ ay have affected the experim ental results.G. pulex has a natural life-span of 1 to 2 years and possibly experienced a low reproductive effort during the freshwater experim ent [332]. A longer life-span of G. pulex (11 - $15 \mathrm{~m}$ onths at $15^{\circ} \mathrm{C}$ [333]) com pared toG. locusta (5-6 $\mathrm{m}$ onths at $15^{\circ} \mathrm{C}$ [313]) and/or lower reproductive effort of fem ale G. pulex during the freshwater experim ent $\mathrm{m}$ ay have caused an increase in the energy budget inG. pulex com pared $\mathrm{b}$ that of G. locusta, and thus their capacity of avoidance during DMA exposure.

In addition, it is not known whether slightly hypersaline conditions $(40-42 \mathrm{~m} \mathrm{~S} / \mathrm{cm}$, Table S3) could have resulted in intraspecific differences in G. locusta growth [334] or if a likely osm otic im balance inG. locusta [335] $\mathrm{m}$ ay have been enhanced by oil exposure.

Osm oregulation is an energy-consum ing regulatory function in Gammarus spp. in a way that its alteration $m$ ay reduce the energy allocated to locom otion and ventilation. A com bined effect of osm oregulaion- and reproduction-related energy consum ption $m$ ay have reduced the ability of G. locusta to ‘escape’ from DMA, whereas G. pulex energy allocation to hyperventilation during acclim atization, $\mathrm{m}$ ay be com pensated by an early DMA detection, via ventilation, and long-term stability of glycogen reserves. 


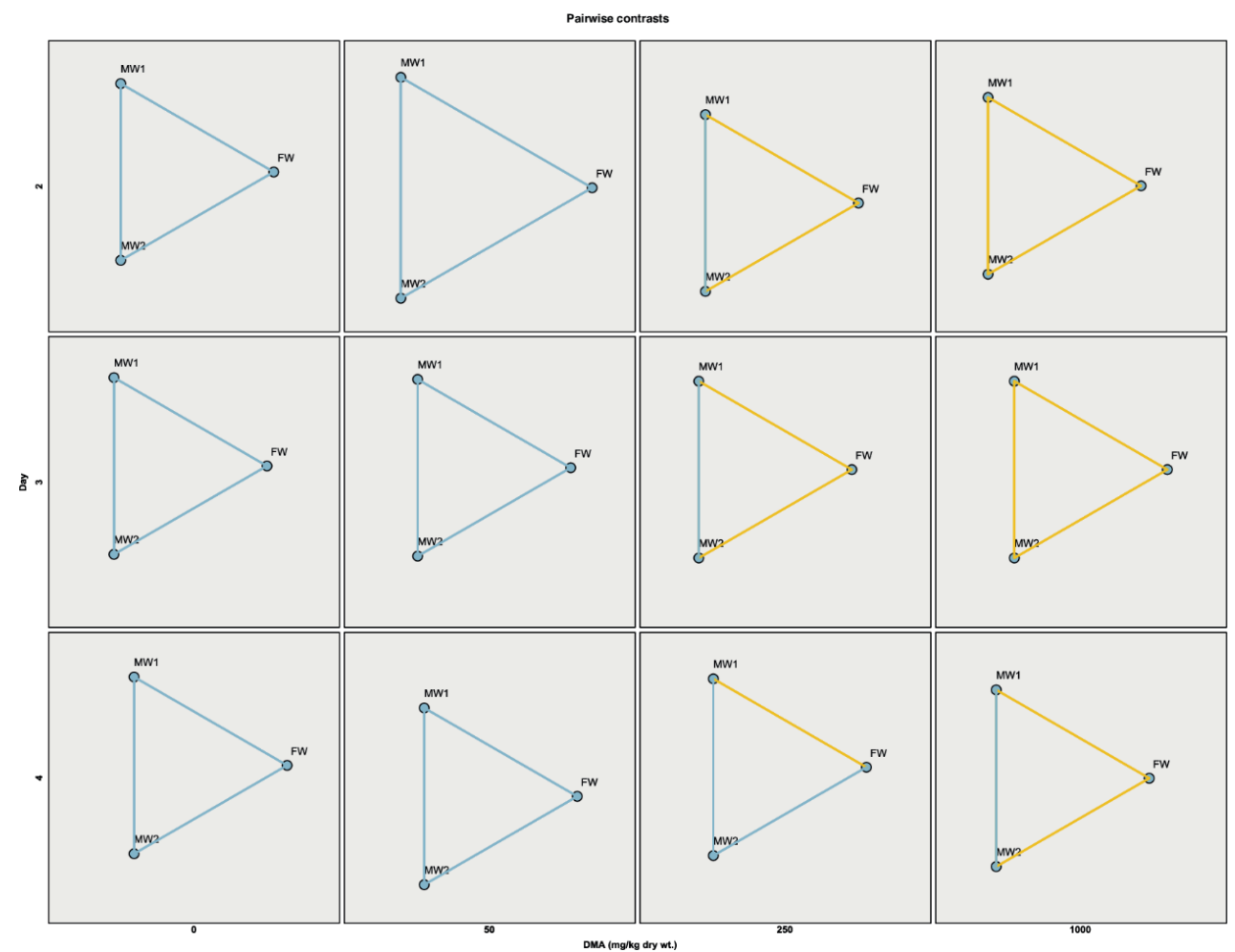

Figure 5. Generalized linear $m$ ixed $m$ odels experim ent $\times$ treatm ent $\times$ day' pairwise contrasts for Gammarus pulex (FW experim ent) andGammarus locusta (MW1 and MW2 experim ents) exposed to Distillate Marine grade A (DMA) oil. Avoidance is expressed as num ber of individuals staying for at least 5 to 6 consecutive seconds within the control section per DMA treatm ent $(0-1000 \mathrm{mg} / \mathrm{kgdry} w \mathrm{wt}$.$) and day (2-4)$. Significant contrasts $(p \leq 0.05)$ are shaded gold.

\subsection{Implications for the use of avoidance tests with Gammarus spp.}

The present study showed that spatial avoidance $m$ ay be integrated in the current risk assessm ent fram ework due to its higher sensitivity than m ortality326]. However, the interpretation of spatial avoidance results required som e assum ptions to be $\mathrm{m}$ ade related to inter-individual variability. Such variability $\mathrm{m}$ ay be greater in sum $\mathrm{m}$ er generations because their reproductive effort should be m axim ized when their lifespan is shortened by high tem peratures and this would restrict their capacity to cope with $\mathrm{m}$ etabolic stres. Therefore, a supporting analysis of energy consum ption in am phipods $m$ ay help to establish if their energy budget is affected by the energy allocation to avoidance of oil and if such trade-off follows a seasonal pattern according to the species reproductive strategy. Avoidance results obtained 


\section{Chapter 5}

under such com bined analysis could also be translated into a recognizable pattern of effects on growth and reproduction in short life-span species.

In the present study, nom inal DMA concentrations were chosen according to the range of DMA oil concentrations for which a $\mathrm{K}_{\mathrm{d}}$ decrease had been observed for $\mathrm{m}$ ost PAHs byJonker et al. [46]. However, variability in PAH partitioning due to differences in the storage tim e of sedim ent treatm ents $\mathrm{m}$ ight have affected the com parability between the present avoidance tests. This stresses the im portance of including a chem ical characterization of sedim ent treatm ents prior to and after avoidance tests, as well as of the overlying water during exposure for each replicate [83]. The interpretation of avoidance results $m$ ay also be im proved after the inclusion of a statistically sufficient num ber of recordings between the tim e to achieve a uniform distribution in control reatm ent replicates[101] and the end of recording on the first day of exposure. Such additional recordings would serve to identify the possibility of a reversible narcotic effect, reducing the risk of bias.

The interpretation of results $\mathrm{m}$ ay be further im proved using a $\mathrm{m}$ ore gradual acclim ation to standard tem perature and salinity conditions in fieldcollected organism s. Acclim ation can be energy dem anding in am phipods and $m$ aynifluence their energy allocation to avoidance. This was hypothesized for $G$. pulex as the acclim ation to standard tem perature regim es could have affected its energy $m$ etabolism and thus, sensitivity to tem perature and other stressor[336]. Sim ilarly, it is not known if the variation in salinity could have contributed to the observed variability in $G$. locusta experim ents. In both cases, the observed variability could have been associated to different rates of energy consum ption am ong lifespan stages during acclim atization. In addition, factors such as thereproductive or $\mathrm{m}$ oulting stage could influence the chem ical exchange at body surface and sensitivity to oil of am phipods.

Consequently, sam pling efforts should be addressed to specific periods at which contributing factors to the sensitivity to oil in am phipods are $\mathrm{m}$ ore uniform am ong gam $\mathrm{m}$ arid populations. One needs to consider as well how seasonality $m$ ay influence the energy reserves and activity of test organism $\mathrm{s}$ as this would facilitate the extrapolation of avoidance results between studies from different clim ate regions. Avoidance of oil can be a useful tool to relate energy consum ption to growth reduction and delated $\mathrm{m}$ aturation in adult am phipods, helping to predict the environm ental risks derived from their behavioral reaction. A com bined $\mathrm{m}$ onitoring ofspatial avoidance and $\mathrm{m}$ etabolic responses and its integration in risk analysis 
$\mathrm{m}$ ay therefore help to anticipate in which exposure scenarios gam $\mathrm{m}$ arid populations can recover from an oil spill following habitat fragm entation[16,295].

\section{Conclusions}

In our experim ents, it was observed that the freshwater am phipodG. pulex avoided DMAspiked sedim ent at $1000 \mathrm{~m} \mathrm{~g} / \mathrm{kg}$ (dry wt.). For the $\mathrm{m}$ arine am phipodG. locusta, avoidance was either not consistent with tim e or below effectthreshold. Oil behavior $m$ ay have differed in the freshwater experim ent com pared to the $m$ arine experim ents, despite a sim ilar spiking protocol. Season-related differences in the physiology of am phipod species $\mathrm{m}$ ay restrict the applicability of avoidance tests to non-reproductive and/or winter individuals. Besides the inclusion of scoring on the first day of exposure, we recom $m$ end the analysis of energy reserves dynam ics in am phipods in order to ascertain whether any experim ental factors other than the exposure duration can significantly alter the energy allocation to locom otion. The predictive power of avoidance tests using am phipod species could be increased after the identification of biological factors that $\mathrm{m}$ ay influence sensitivity to oil exposure in sedm ent.

\section{Acknowledgements}

Equinor ASA and the Wageningen UR TripleP@Sea innovation program m e (The Netherlands) are acknowledged for funding the ARCIND project. 


\section{Chapter 5}

\section{Supporting Information}

Table S1. Gammarus pulex average water quality variables during acclim tization.

\begin{tabular}{ccccc}
\hline Day & Tem perature $\left({ }^{\circ} \mathrm{C}\right)$ & Oxygen $(\mathrm{mg} / \mathrm{L})$ & Electric conductivity $(\mu \mathrm{S} / \mathrm{cm})$ & $\mathrm{pH}$ \\
\hline 1 & $15.6 \pm 0.1$ & $9.3 \pm 0.1$ & $401.8 \pm 0.5$ & $7.3 \pm 0.0$ \\
2 & $15.6 \pm 0.0$ & $9.2 \pm 0.2$ & $404.5 \pm 1.7$ & $7.2 \pm 0.0$ \\
3 & $15.6 \pm 0.0$ & $9.9 \pm 0.1$ & $378.8 \pm 4.3$ & $7.5 \pm 0.0$ \\
4 & $15.7 \pm 0.1$ & $9.5 \pm 0.2$ & $357.5 \pm 5.1$ & $7.5 \pm 0.0$ \\
5 & $15.8 \pm 0.0$ & $9.5 \pm 0.2$ & $342.3 \pm 7.3$ & $7.6 \pm 0.0$ \\
6 & $15.7 \pm 0.1$ & $9.4 \pm 0.2$ & $327.3 \pm 9.0$ & $7.7 \pm 0.0$ \\
7 & $16.4 \pm 0.0$ & $10.1 \pm 0.1$ & $198.6 \pm 4.2$ & $7.9 \pm 0.0$ \\
8 & $16.4 \pm 0.0$ & $9.8 \pm 0.2$ & $204.6 \pm 7.1$ & $7.8 \pm 0.0$ \\
9 & $16.4 \pm 0.0$ & $9.4 \pm 0.1$ & $208.8 \pm 8.2$ & $7.8 \pm 0.0$ \\
\hline
\end{tabular}

Table S2. First marine experim ent (MW1) average water quality variables based on three experim ental replicates withoutGammarus locusta individuals.

\begin{tabular}{ccccc}
\hline Exposure day & Salinity $(\mathrm{m} \mathrm{S} / \mathrm{cm})$ & Tem perature $\left({ }^{\circ} \mathrm{C}\right)$ & Oxygen $(\mathrm{m} \mathrm{g} / \mathrm{L})$ & $\mathrm{pH}$ \\
\hline 1 & 40.1 & 16.1 & 7.1 & 7.8 \\
2 & 40.7 & 16.8 & 6.5 & 8.0 \\
3 & 41.3 & 16.6 & 7.0 & 8.2 \\
4 & 41.5 & 16.3 & 7.4 & 8.2 \\
\hline
\end{tabular}

Table S3. End of exposure (day 4) water quality variables per Distillate Marine grade A (DMA) oil sedim ent treatm ent (average \pm SD) inGammarus pulex (FW) and Gammarus locusta (MW1 and MW2) experim ents.

\begin{tabular}{cccccc}
\hline Experim ent & DMA $(\mathrm{m} \mathrm{g} / \mathrm{kg}$ drywt.) & Salinity $(\mathrm{m} \mathrm{S} / \mathrm{cm})$ & Tem perature $\left({ }^{\circ} \mathrm{C}\right)$ & Oxygen $(\mathrm{m} \mathrm{g} / \mathrm{L})$ & $\mathrm{pH}$ \\
\hline \multirow{3}{*}{ FW } & 0 & - & n.a. & n.a. & n.a. \\
& 50 & - & n.a. & n.a. & n.a. \\
& 250 & - & n.a. & n.a. & n.a. \\
\hline \multirow{3}{*}{ MW1 } & 1000 & - & n.a. & n.a. & n.a. \\
& 0 & $42.2 \pm 0.2$ & $16.3 \pm 0.1$ & $6.3 \pm 0.3$ & $8.2 \pm 0.0$ \\
& 50 & $42.1 \pm 0.1$ & $16.4 \pm 0.2$ & $6.0 \pm 0.3$ & $8.2 \pm 0.0$ \\
& 1000 & $42.2 \pm 0.3$ & $16.3 \pm 0.1$ & $6.3 \pm 0.4$ & $8.2 \pm 0.0$ \\
MW2 & 0 & $41.4 \pm 0.9$ & $15.4 \pm 0.1$ & $5.2 \pm 0.3$ & $8.1 \pm 0.1$ \\
& 50 & $40.5 \pm 0.9$ & $15.4 \pm 0.1$ & $5.4 \pm 0.8$ & $8.0 \pm 0.2$ \\
& 250 & $40.7 \pm 1.9$ & $15.4 \pm 0.1$ & $5.2 \pm 0.3$ & $8.0 \pm 0.0$ \\
\hline
\end{tabular}

n.a.: not available. 
Chapter 5

Table S4. Estimated means of target variable (Individuals in control section) for "Treatment $\times$ Day" effect on Gammarus pulex avoidance.

\begin{tabular}{crrrrr}
\hline \multirow{2}{*}{$\begin{array}{c}\text { DMA treatm ent } \\
\text { (m g/kgdry wt.) }\end{array}$} & Day & Mean & SE & \multicolumn{2}{c}{ 95\% confidence interval } \\
\cline { 5 - 6 } 0 & 2 & 7.896 & 0.636 & 6.639 & 9.152 \\
\hline \multirow{2}{*}{0} & 3 & 8.485 & 0.794 & 6.919 & 10.052 \\
& 4 & 7.474 & 0.652 & 6.186 & 8.762 \\
\hline \multirow{2}{*}{50} & 2 & 7.378 & 0.615 & 6.164 & 8.593 \\
& 3 & 7.982 & 0.770 & 6.462 & 9.501 \\
& 4 & 6.588 & 0.613 & 5.379 & 7.797 \\
\hline \multirow{2}{*}{250} & 2 & 10.034 & 0.717 & 8.618 & 11.450 \\
& 3 & 9.798 & 0.853 & 8.114 & 11.482 \\
& 4 & 9.066 & 0.719 & 7.647 & 10.485 \\
\hline \multirow{2}{*}{1000} & 2 & 12.727 & 0.808 & 11.131 & 14.322 \\
& 3 & 11.648 & 0.930 & 9.812 & 13.483 \\
& 4 & 11.746 & 0.818 & 10.131 & 13.360 \\
\hline
\end{tabular}




\section{Chapter 5}

Table S5. Pairwise contrasts for "Treatment $\times$ Day" effect on Gammarus pulex avoidance.

\begin{tabular}{|c|c|c|c|c|c|c|c|c|}
\hline \multirow{2}{*}{ Day } & \multirow{2}{*}{$\begin{array}{l}\text { DMA treatm ent } \\
\text { pairwise contrast } \\
\text { (m g/kg dry wt.) }\end{array}$} & \multirow{2}{*}{$\begin{array}{l}\text { Contrast } \\
\text { estim ate }\end{array}$} & \multirow{2}{*}{$\mathrm{SE}$} & \multirow{2}{*}{$\mathrm{t}$} & \multirow{2}{*}{$\mathrm{df}$} & \multirow{2}{*}{ Adj. sig. } & \multicolumn{2}{|c|}{$95 \%$ confidence interval } \\
\hline & & & & & & & Lower & Upper \\
\hline \multirow{12}{*}{2} & $0-50$ & 0.517 & 0.885 & 0.584 & 168 & 0.560 & -1.230 & 2.265 \\
\hline & $0-250$ & -2.138 & 0.959 & -2.230 & 168 & 0.027 & -4.032 & -0.245 \\
\hline & $0-1000$ & -4.831 & 1.029 & -4.697 & 168 & $5.461 \mathrm{E}-06$ & -6.862 & -2.801 \\
\hline & $50-0$ & -0.517 & 0.885 & -0.584 & 168 & 0.560 & -2.265 & 1.230 \\
\hline & $50-250$ & -2.656 & 0.945 & -2.810 & 168 & 0.006 & -4.521 & -0.790 \\
\hline & $50-1000$ & -5.348 & 1.016 & -5.266 & 168 & $4.212 \mathrm{E}-07$ & -7.353 & -3.343 \\
\hline & $250-0$ & 2.138 & 0.959 & 2.230 & 168 & 0.027 & 0.245 & 4.032 \\
\hline & $250-50$ & 2.656 & 0.945 & 2.810 & 168 & 0.006 & 0.790 & 4.521 \\
\hline & $250-1000$ & -2.693 & 1.081 & -2.492 & 168 & 0.014 & -4.826 & -0.560 \\
\hline & $1000-0$ & 4.831 & 1.029 & 4.697 & 168 & $5.461 \mathrm{E}-06$ & 2.801 & 6.862 \\
\hline & $1000-50$ & 5.348 & 1.016 & 5.266 & 168 & $4.212 \mathrm{E}-07$ & 3.343 & 7.353 \\
\hline & $1000-250$ & 2.693 & 1.081 & 2.492 & 168 & 0.014 & 0.560 & 4.826 \\
\hline \multirow{12}{*}{3} & $0-50$ & 0.504 & 1.106 & 0.456 & 168 & 0.649 & -1.679 & 2.686 \\
\hline & $0-250$ & -1.313 & 1.165 & -1.127 & 168 & 0.262 & -3.612 & 0.987 \\
\hline & $0-1000$ & -3.162 & 1.223 & -2.587 & 168 & 0.011 & -5.576 & -0.749 \\
\hline & $50-0$ & -0.504 & 1.106 & -0.456 & 168 & 0.649 & -2.686 & 1.679 \\
\hline & $50-250$ & -1.816 & 1.149 & -1.581 & 168 & 0.116 & -4.084 & 0.452 \\
\hline & $50-1000$ & -3.666 & 1.207 & -3.037 & 168 & 0.003 & -6.049 & -1.283 \\
\hline & $250-0$ & 1.313 & 1.165 & 1.127 & 168 & 0.262 & -0.987 & 3.612 \\
\hline & $250-50$ & 1.816 & 1.149 & 1.581 & 168 & 0.116 & -0.452 & 4.084 \\
\hline & $250-1000$ & -1.850 & 1.262 & -1.466 & 168 & 0.145 & -4.341 & 0.641 \\
\hline & $1000-0$ & 3.162 & 1.223 & 2.587 & 168 & 0.011 & 0.749 & 5.576 \\
\hline & $1000-50$ & 3.666 & 1.207 & 3.037 & 168 & 0.003 & 1.283 & 6.049 \\
\hline & $1000-250$ & 1.850 & 1.262 & 1.466 & 168 & 0.145 & -0.641 & 4.341 \\
\hline
\end{tabular}


Chapter 5

Table S5. Continued.

\begin{tabular}{llrrrrrrr}
\hline \multirow{2}{*}{ Day $\begin{array}{c}\text { DMA treatm ent } \\
\text { pairwise contrast } \\
(\mathrm{m} \mathrm{g} / \mathrm{kg} \text { dry wt. })\end{array}$} & $\begin{array}{c}\text { Contrast } \\
\text { estim ate }\end{array}$ & $\mathrm{SE}$ & $\mathrm{t}$ & $\mathrm{df}$ & Adj. sig. & \multicolumn{2}{c}{ 95\% confidence interval } \\
\hline $0-50$ & 0.886 & 0.895 & 0.991 & 168 & 0.323 & -0.880 & 2.653 \\
$0-250$ & -1.592 & 0.971 & -1.640 & 168 & 0.103 & -3.508 & 0.324 \\
$0-1000$ & -4.271 & 1.046 & -4.083 & 168 & $6.875 \mathrm{E}-05$ & -6.337 & -2.206 \\
$50-0$ & -0.886 & 0.895 & -0.991 & 168 & 0.323 & -2.653 & 0.880 \\
$50-250$ & -2.478 & 0.944 & -2.625 & 168 & 0.009 & -4.342 & -0.614 \\
$50-1000$ & -5.158 & 1.022 & -5.048 & 168 & $1.154 \mathrm{E}-06$ & -7.175 & -3.141 \\
$250-0$ & 1.592 & 0.971 & 1.640 & 168 & 0.103 & -0.324 & 3.508 \\
$250-50$ & 2.478 & 0.944 & 2.625 & 168 & 0.009 & 0.614 & 4.342 \\
$250-1000$ & -2.680 & 1.089 & -2.461 & 168 & 0.015 & -4.829 & -0.530 \\
$1000-0$ & 4.271 & 1.046 & 4.083 & 168 & $6.875 \mathrm{E}-05$ & 2.206 & 6.337 \\
$1000-50$ & 5.158 & 1.022 & 5.048 & 168 & $1.154 \mathrm{E}-06$ & 3.141 & 7.175 \\
$1000-250$ & 2.680 & 1.089 & 2.461 & 168 & 0.015 & 0.530 & 4.829 \\
\hline
\end{tabular}

Table S6. Overall generalized linear mixed models test results for "Treatment $\times$ Day" effect on Gammarus pulex avoidance.

\begin{tabular}{crrrr}
\hline Day & \multicolumn{1}{c}{ F } & df1 & df2 & \multicolumn{1}{c}{ Sig. } \\
\hline 2 & 11.084 & 3 & 168 & $1.122 \mathrm{E}-06$ \\
3 & 3.567 & 3 & 168 & 0.015 \\
4 & 9.433 & 3 & 168 & $8.541 \mathrm{E}-06$ \\
\hline
\end{tabular}




\section{Chapter 5}

Table S7. Estimated means of target variable (Individuals in control section) for "Treatment $\times$ Day" effect on Gammarus locusta avoidance in the first m arine experim at (MW1).

\begin{tabular}{ccrccr}
\hline $\begin{array}{c}\text { DMA treatm ent } \\
\text { (m g/kgdry wt.) }\end{array}$ & Day & Mean & SE & \multicolumn{2}{c}{$95 \%$ confidence interval } \\
\hline \multirow{3}{*}{0} & 2 & 7.536 & 0.369 & 6.812 & 8.261 \\
& 3 & 7.113 & 0.372 & 6.382 & 7.844 \\
& 4 & 7.041 & 0.332 & 6.389 & 7.692 \\
\hline \multirow{3}{*}{50} & 2 & 7.759 & 0.374 & 7.024 & 8.495 \\
& 3 & 7.133 & 0.372 & 6.401 & 7.865 \\
& 4 & 7.502 & 0.342 & 6.829 & 8.174 \\
\hline \multirow{3}{*}{250} & 2 & 8.106 & 0.382 & 7.354 & 8.857 \\
& 3 & 7.505 & 0.382 & 6.754 & 8.256 \\
& 4 & 6.711 & 0.324 & 6.075 & 7.347 \\
\hline \multirow{3}{*}{1000} & 2 & 10.140 & 0.428 & 9.300 & 10.981 \\
& 3 & 9.123 & 0.421 & 8.295 & 9.951 \\
& 4 & 7.712 & 0.347 & 7.030 & 8.394 \\
\hline
\end{tabular}




\section{Chapter 5}
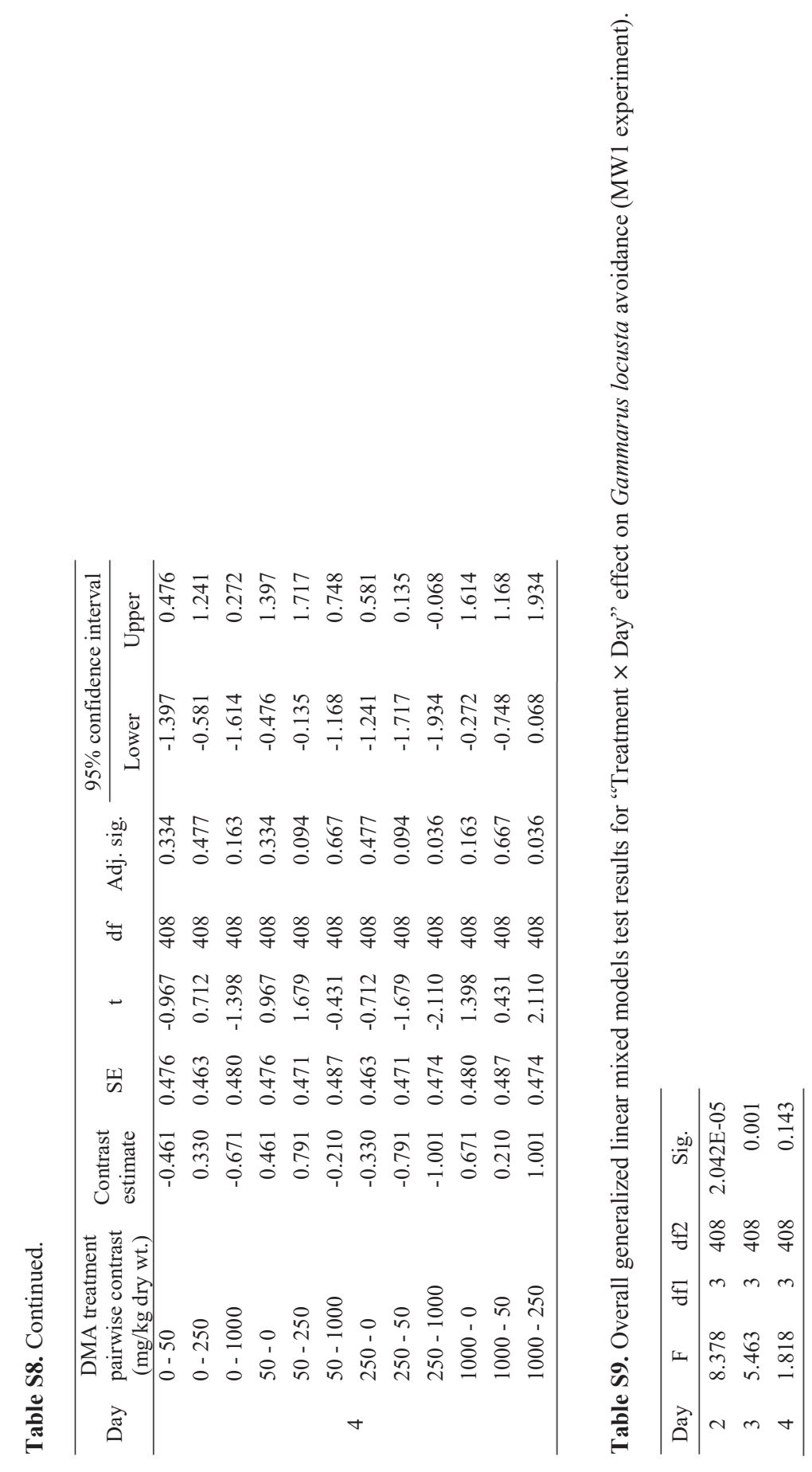
Chapter 5

Table S10. Estim ated $m$ eans of target variable (Individuals in ontrol section) for "Treatment $\times$ Day" effect on Gammarus locusta avoidance in the second m arine experim ent (MW2).

\begin{tabular}{cccccc}
\hline \multirow{2}{*}{$\begin{array}{c}\text { DMA treatm ent } \\
\text { (m g/kgdry wt.) }\end{array}$} & Day & Mean & SE & \multicolumn{3}{c}{$95 \%$ confidence interval } \\
\cline { 5 - 6 } 0 & 2 & 7.995 & 0.369 & 7.270 & 8.720 \\
& 3 & 7.355 & 0.416 & 6.537 & 8.174 \\
& 4 & 7.897 & 0.403 & 7.104 & 8.689 \\
\hline \multirow{2}{*}{50} & 2 & 7.662 & 0.361 & 6.952 & 8.371 \\
& 3 & 7.184 & 0.412 & 6.375 & 7.993 \\
& 4 & 7.583 & 0.395 & 6.807 & 8.360 \\
\hline \multirow{2}{*}{250} & 2 & 7.994 & 0.369 & 7.269 & 8.718 \\
& 3 & 7.589 & 0.423 & 6.757 & 8.420 \\
& 4 & 8.378 & 0.415 & 7.561 & 9.194 \\
\hline \multirow{2}{*}{1000} & 2 & 8.182 & 0.373 & 7.448 & 8.915 \\
& 3 & 6.787 & 0.400 & 6.001 & 7.574 \\
& 4 & 7.527 & 0.394 & 6.754 & 8.301 \\
\hline
\end{tabular}




\section{Chapter 5}

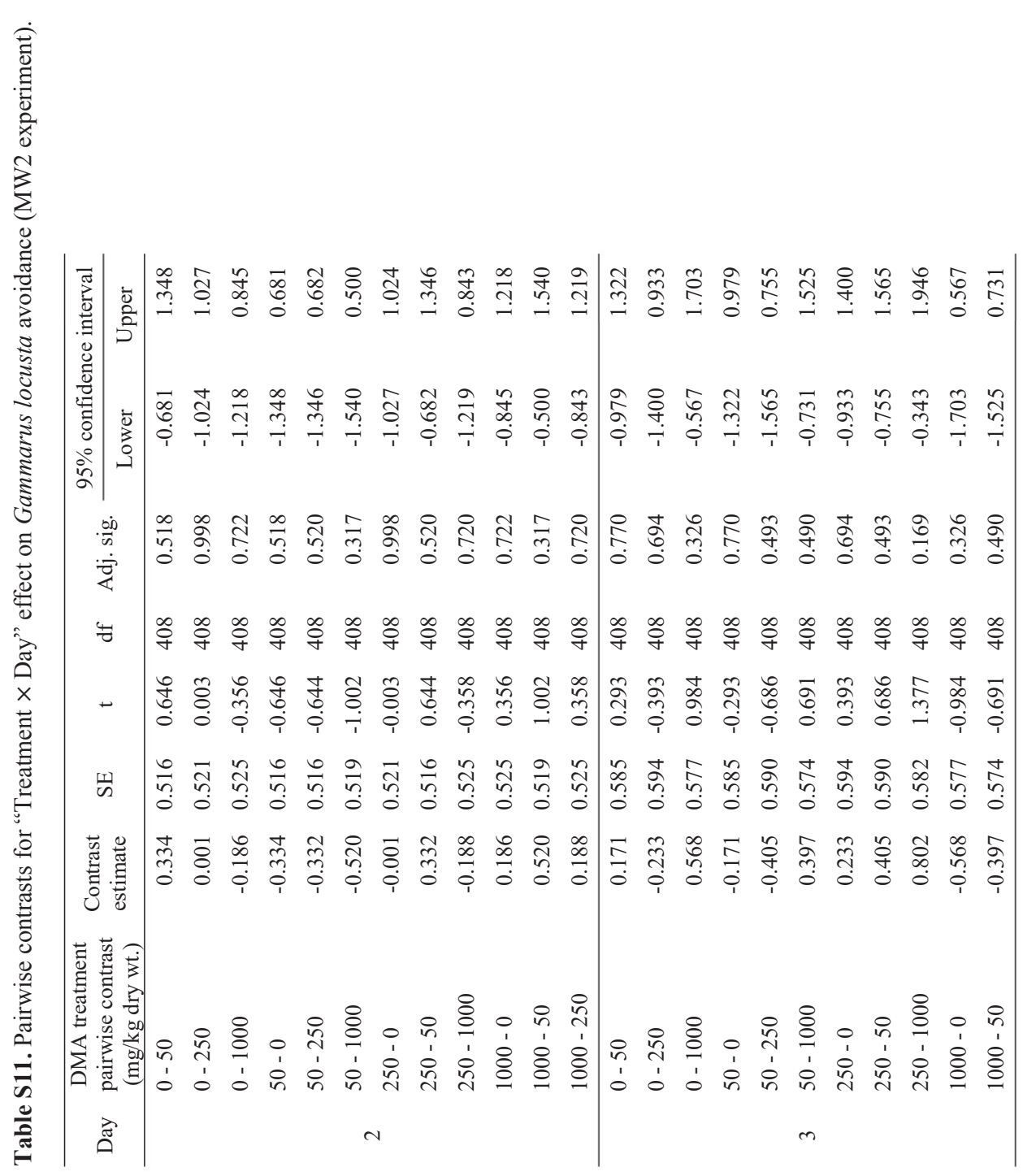


Chapter 5
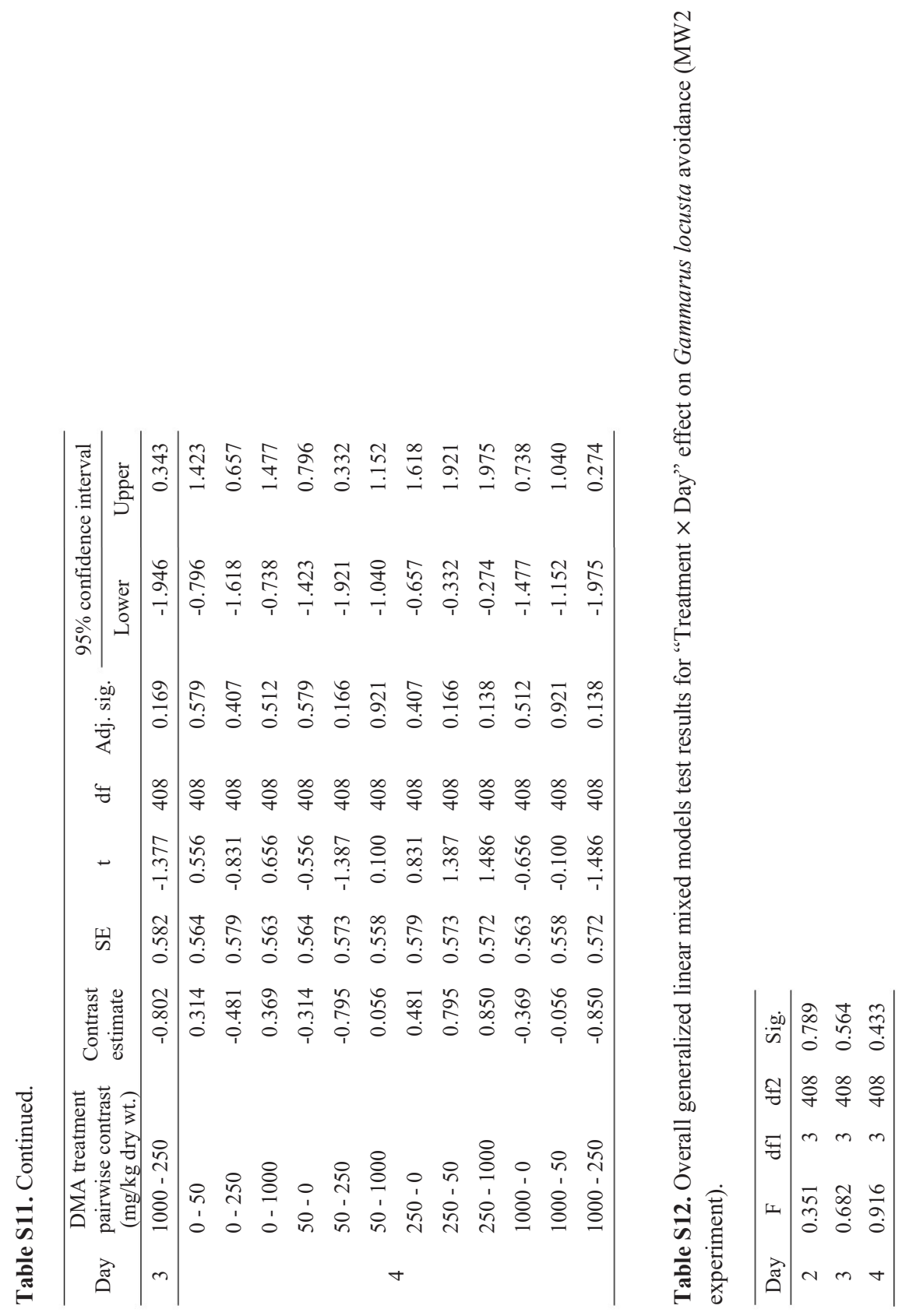


\section{Chapter 5}

Table S13. Estimated means of target variable (Individuals in control section) for "Experiment $x$ Treatm ent× Day" effect on Gammarus locusta avoidance (MW1 and MW2 experim ents).

\begin{tabular}{|c|c|c|c|c|c|c|}
\hline \multirow{2}{*}{ Experim ent } & \multirow{2}{*}{$\begin{array}{l}\text { DMA treatm ent } \\
\text { (m g/kg dry wt) }\end{array}$} & \multirow{2}{*}{ Day } & \multirow{2}{*}{ Mean } & \multirow{2}{*}{ SE } & \multicolumn{2}{|c|}{$95 \%$ confidence interval } \\
\hline & & & & & Lower & Upper \\
\hline \multirow{12}{*}{ MW1 } & \multirow{3}{*}{0} & 2 & 7.443 & 0.381 & 6.695 & 8.192 \\
\hline & & 3 & 7.027 & 0.394 & 6.253 & 7.801 \\
\hline & & 4 & 7.159 & 0.379 & 6.414 & 7.903 \\
\hline & \multirow{3}{*}{50} & 2 & 7.682 & 0.388 & 6.921 & 8.443 \\
\hline & & 3 & 7.197 & 0.399 & 6.414 & 7.981 \\
\hline & & 4 & 7.396 & 0.386 & 6.639 & 8.153 \\
\hline & \multirow{3}{*}{250} & 2 & 8.206 & 0.401 & 7.420 & 8.992 \\
\hline & & 3 & 7.495 & 0.407 & 6.696 & 8.295 \\
\hline & & 4 & 7.257 & 0.382 & 6.507 & 8.007 \\
\hline & \multirow{3}{*}{1000} & 2 & 9.918 & 0.440 & 9.053 & 10.782 \\
\hline & & 3 & 9.099 & 0.449 & 8.218 & 9.980 \\
\hline & & 4 & 7.674 & 0.393 & 6.903 & 8.444 \\
\hline \multirow{12}{*}{ MW2 } & \multirow{3}{*}{0} & 2 & 7.952 & 0.394 & 7.178 & 8.726 \\
\hline & & 3 & 7.422 & 0.405 & 6.626 & 8.218 \\
\hline & & 4 & 7.701 & 0.393 & 6.928 & 8.473 \\
\hline & \multirow{3}{*}{50} & 2 & 7.644 & 0.387 & 6.885 & 8.403 \\
\hline & & 3 & 7.058 & 0.395 & 6.282 & 7.834 \\
\hline & & 4 & 7.684 & 0.393 & 6.913 & 8.456 \\
\hline & \multirow{3}{*}{250} & 2 & 8.068 & 0.397 & 7.288 & 8.847 \\
\hline & & 3 & 7.584 & 0.410 & 6.779 & 8.388 \\
\hline & & 4 & 8.194 & 0.406 & 7.398 & 8.991 \\
\hline & \multirow{3}{*}{1000} & 2 & 8.085 & 0.398 & 7.305 & 8.866 \\
\hline & & 3 & 6.872 & 0.390 & 6.106 & 7.637 \\
\hline & & 4 & 7.555 & 0.390 & 6.790 & 8.320 \\
\hline
\end{tabular}




\section{Chapter 5}

Table S15. Overall generalized linear mixed models test results for "Experiment $\times$ Treatm ent $\times$ Day" effect on Gammarus locusta avoidance (MW1 and MW2 experim ents).

\begin{tabular}{cccccc}
\hline $\begin{array}{l}\text { DMA treatm ent } \\
\text { (m g/kgdry wt. })\end{array}$ & Day & $F$ & df1 & df2 & Sig. \\
\hline \multirow{2}{*}{0} & 2 & 0.859 & 1 & 816 & 0.354 \\
& 3 & 0.488 & 1 & 816 & 0.485 \\
& 4 & 0.984 & 1 & 816 & 0.322 \\
\hline \multirow{2}{*}{50} & 2 & 0.005 & 1 & 816 & 0.945 \\
& 3 & 0.061 & 1 & 816 & 0.805 \\
& 4 & 0.274 & 1 & 816 & 0.601 \\
\hline \multirow{2}{*}{250} & 2 & 0.060 & 1 & 816 & 0.806 \\
& 3 & 0.023 & 1 & 816 & 0.878 \\
& 4 & 2.827 & 1 & 816 & 0.093 \\
\hline \multirow{2}{*}{1000} & 2 & 9.538 & 1 & 816 & 0.002 \\
& 3 & 14.026 & 1 & 816 & 0.000 \\
& 4 & 0.046 & 1 & 816 & 0.831 \\
\hline
\end{tabular}


Chapter 5

Table S16. Estimated means of target variable (Individuals in control section) for "Experim ent $\times$ Treatm ent $\times$ Day" effect on Gammarus pulex (FW experim ent) andGammarus locusta avoidance (MW1 and MW2 experim ents).

\begin{tabular}{|c|c|c|c|c|c|c|}
\hline \multirow{2}{*}{ Experim ent } & \multirow{2}{*}{$\begin{array}{l}\text { DMA treatm ent } \\
\text { (m g/kg dry wt.) }\end{array}$} & \multirow{2}{*}{ Day } & \multirow{2}{*}{ Mean } & \multirow{2}{*}{$\mathrm{SE}$} & \multicolumn{2}{|c|}{$95 \%$ confidence interval } \\
\hline & & & & & Lower & Upper \\
\hline \multirow{12}{*}{ FW } & \multirow{3}{*}{0} & 2 & 7.688 & 0.639 & 6.434 & 8.942 \\
\hline & & 3 & 8.498 & 0.674 & 7.174 & 9.821 \\
\hline & & 4 & 7.810 & 0.658 & 6.520 & 9.101 \\
\hline & \multirow{3}{*}{50} & 2 & 7.800 & 0.644 & 6.537 & 9.063 \\
\hline & & 3 & 7.991 & 0.654 & 6.707 & 9.274 \\
\hline & & 4 & 6.644 & 0.607 & 5.454 & 7.835 \\
\hline & \multirow{3}{*}{250} & 2 & 10.093 & 0.732 & 8.656 & 11.530 \\
\hline & & 3 & 9.784 & 0.724 & 8.364 & 11.204 \\
\hline & & 4 & 9.249 & 0.716 & 7.844 & 10.653 \\
\hline & \multirow{3}{*}{1000} & 2 & 12.819 & 0.825 & 11.199 & 14.438 \\
\hline & & 3 & 11.663 & 0.790 & 10.112 & 13.214 \\
\hline & & 4 & 11.802 & 0.808 & 10.215 & 13.388 \\
\hline \multirow{12}{*}{ MW1 } & \multirow{3}{*}{0} & 2 & 7.467 & 0.412 & 6.659 & 8.276 \\
\hline & & 3 & 7.024 & 0.392 & 6.255 & 7.793 \\
\hline & & 4 & 7.159 & 0.379 & 6.414 & 7.903 \\
\hline & \multirow{3}{*}{50} & 2 & 7.709 & 0.418 & 6.888 & 8.530 \\
\hline & & 3 & 7.222 & 0.397 & 6.443 & 8.002 \\
\hline & & 4 & 7.396 & 0.386 & 6.639 & 8.153 \\
\hline & \multirow{3}{*}{250} & 2 & 8.190 & 0.431 & 7.344 & 9.036 \\
\hline & & 3 & 7.506 & 0.405 & 6.711 & 8.300 \\
\hline & & 4 & 7.257 & 0.382 & 6.508 & 8.007 \\
\hline & \multirow{3}{*}{1000} & 2 & 10.026 & 0.477 & 9.090 & 10.963 \\
\hline & & 3 & 9.111 & 0.446 & 8.236 & 9.987 \\
\hline & & 4 & 7.674 & 0.393 & 6.903 & 8.444 \\
\hline \multirow{12}{*}{ MW2 } & \multirow{3}{*}{0} & 2 & 7.905 & 0.424 & 7.074 & 8.737 \\
\hline & & 3 & 7.402 & 0.402 & 6.612 & 8.191 \\
\hline & & 4 & 7.701 & 0.393 & 6.929 & 8.473 \\
\hline & \multirow{3}{*}{50} & 2 & 7.601 & 0.415 & 6.785 & 8.416 \\
\hline & & 3 & 7.079 & 0.393 & 6.307 & 7.851 \\
\hline & & 4 & 7.684 & 0.393 & 6.913 & 8.456 \\
\hline & \multirow{3}{*}{250} & 2 & 7.985 & 0.426 & 7.149 & 8.820 \\
\hline & & 3 & 7.598 & 0.407 & 6.798 & 8.397 \\
\hline & & 4 & 8.194 & 0.406 & 7.398 & 8.991 \\
\hline & \multirow{3}{*}{1000} & 2 & 8.154 & 0.430 & 7.309 & 8.998 \\
\hline & & 3 & 6.845 & 0.387 & 6.086 & 7.604 \\
\hline & & 4 & 7.555 & 0.390 & 6.790 & 8.320 \\
\hline
\end{tabular}




\section{Chapter 5}




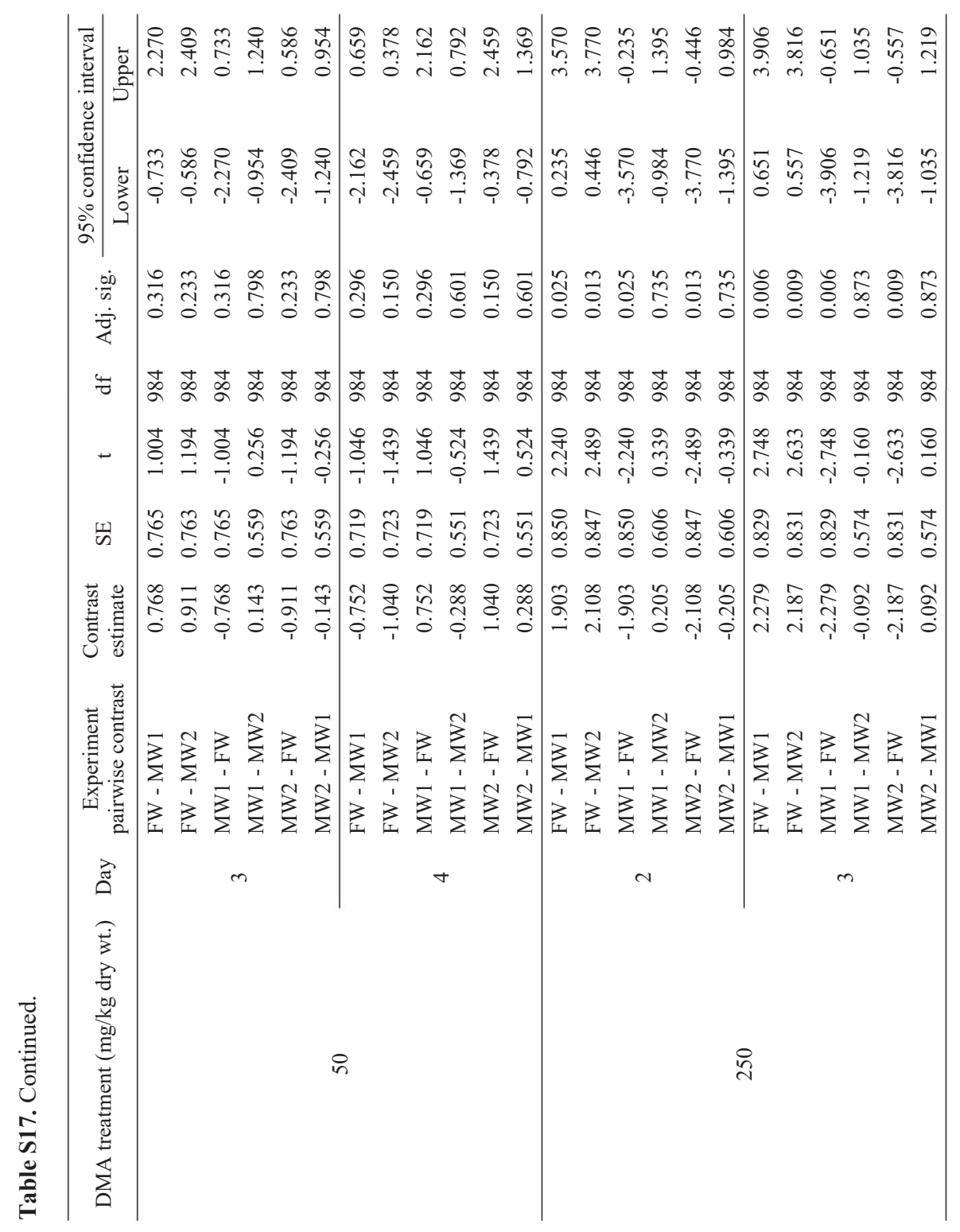




\section{Chapter 5}

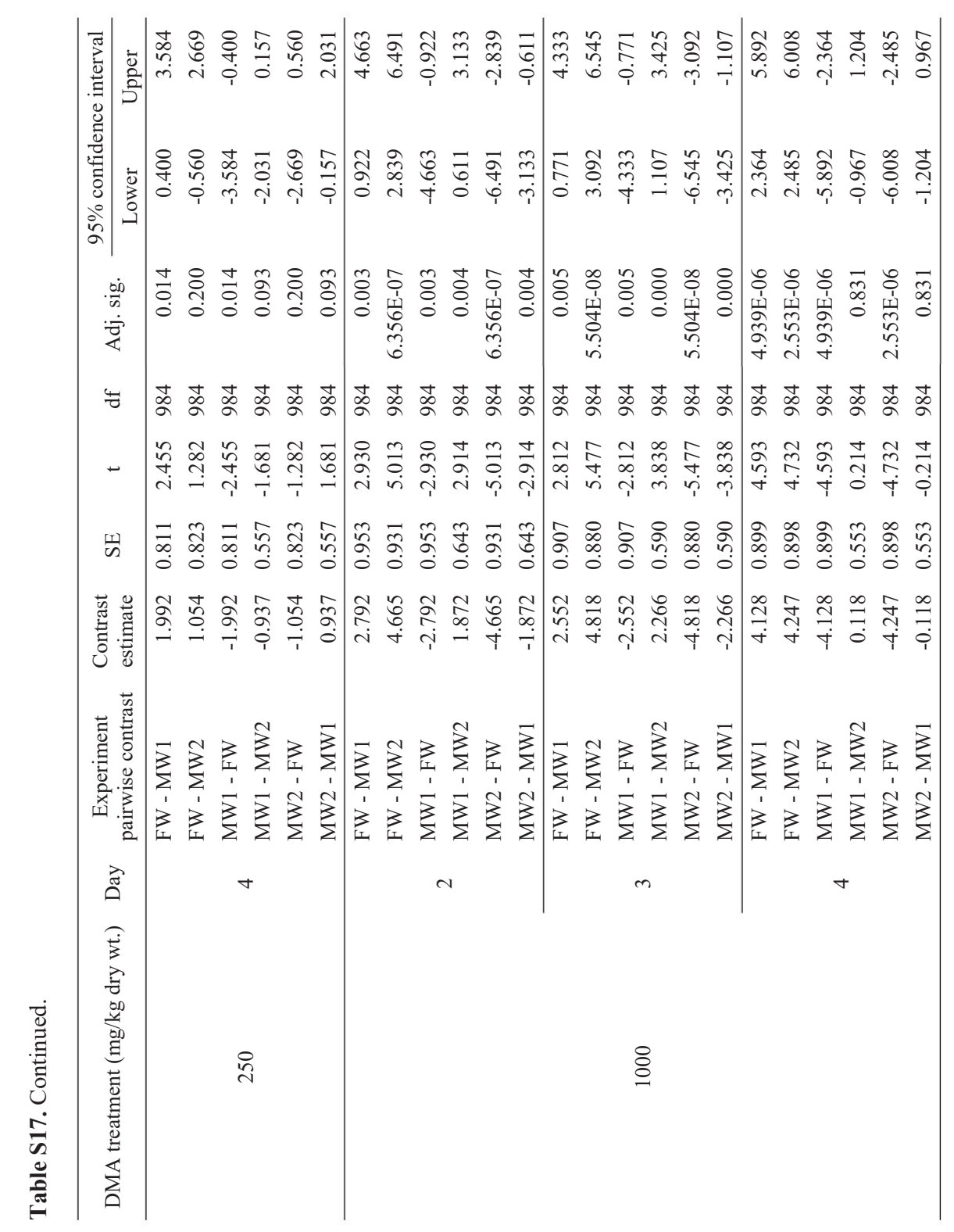

$\oplus$ 
Table S18. Overall generalized linear mixed models test results for "Experiment $\times$ Treatm ent $\times$ Day" effect on Gammarus pulex (FW experim ent) andGammarus locusta avoidance (MW1 and MW2 experim ents).

\begin{tabular}{cccccc}
\hline $\begin{array}{c}\text { DMA treatm ent } \\
\text { (m g/kgdry wt. })\end{array}$ & Day & $F$ & df1 & df2 & \multicolumn{1}{l}{ Sig. } \\
\hline \multirow{2}{*}{0} & 2 & 0.275 & 2 & 984 & 0.760 \\
& 3 & 1.784 & 2 & 984 & 0.168 \\
& 4 & 0.642 & 2 & 984 & 0.526 \\
\hline \multirow{2}{*}{50} & 2 & 0.038 & 2 & 984 & 0.963 \\
& 3 & 0.731 & 2 & 984 & 0.482 \\
& 4 & 1.036 & 2 & 984 & 0.355 \\
\hline \multirow{2}{*}{250} & 2 & 3.265 & 2 & 984 & 0.039 \\
& 3 & 4.124 & 2 & 984 & 0.016 \\
& 4 & 3.455 & 2 & 984 & 0.032 \\
\hline \multirow{2}{*}{1000} & 2 & 13.590 & 2 & 984 & $1.507 \mathrm{E}-06$ \\
& 3 & 17.783 & 2 & 984 & $2.588 \mathrm{E}-08$ \\
& 4 & 12.033 & 2 & 984 & $6.873 \mathrm{E}-06$ \\
\hline
\end{tabular}


6 Synthesis 


\section{Chapter 6}

\section{Introduction}

In the Arctic, com bined effects of clim ate change and globalization will increase oil and gas (O\& G) exploration prospects. This will lead to $\mathrm{m}$ ore $\mathrm{O} \& \mathrm{G}$ and shipping activities[337] causing higher risks of pollution (Figure 1). In Norway and Russia, oil production from existing offshore wells will likely increase in the Barents Sea and Pechora Sea, and Arctic shipping routes such as the Northern Sea Route along the Russian coast are expected to be used $\mathrm{m}$ ore frequently. Such activities will be subjected to sea ice, strong winds and currents, which $m$ ay enhance the risk of accidents during O\& $G$ transpor[338] (Chapter 1).

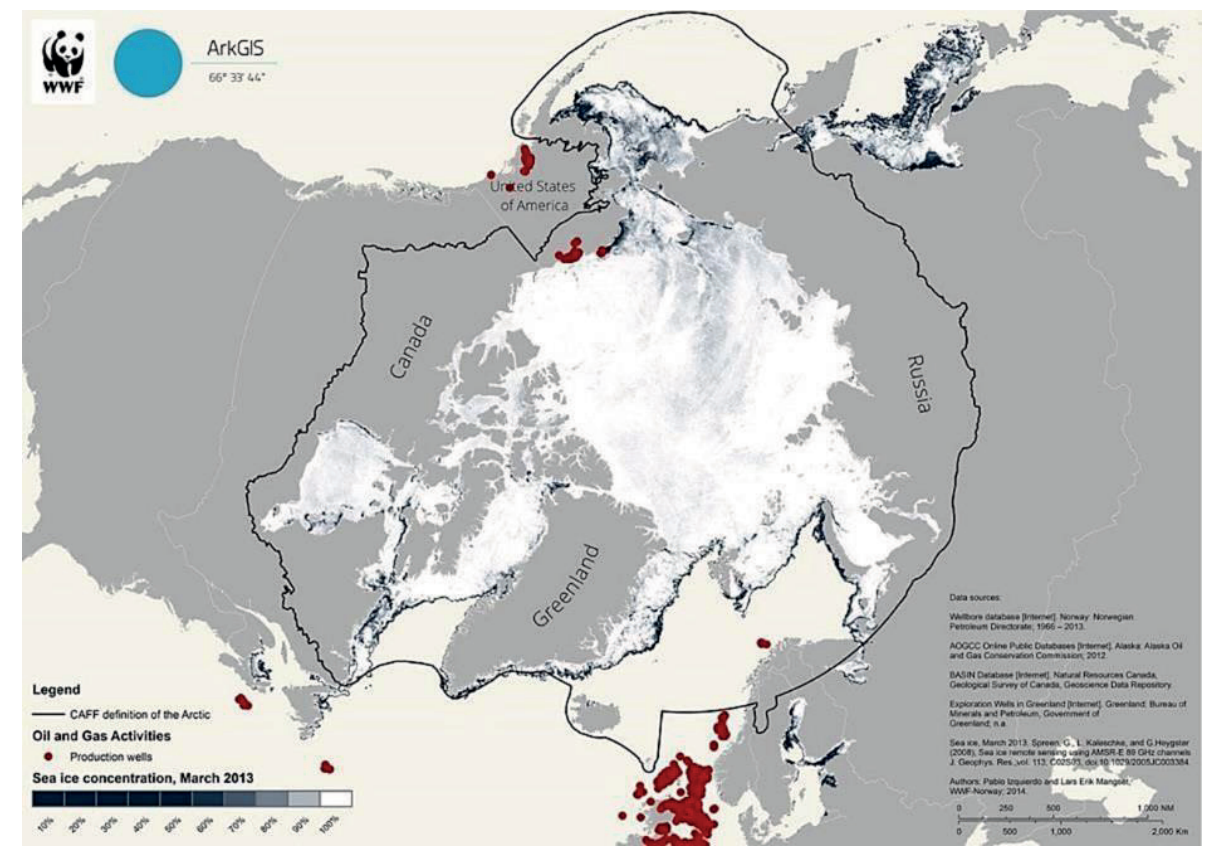

Figure 1. Arctic oil and gas production wells in 2013. Source: http://wwfarcticm aps.org/

Until now, environm ental risks of O\& $\mathrm{G}$ activities in the Arctic havem ainly been evaluated using a conventional environm ental risk assessm ent approach (Figure 2). For instance, threshold values for effects have been established based on species sensitivity distribution (SSD) curves for sub-cellular biom arker responses in water exposed species and for whole organism responses 339,340$]$. On the Norwegian Continental Shelf, environm ental risk assessm ent of produced water (PW) involves the traditional steps in risk assessm ent (Figure 2). These are derived from the European Com $m$ ission[341], and com $m$ only using oil dispersions as proxies for PW and other crude oil discharges. Such conventional approaches 
$\mathrm{m}$ ainlyapply to the water colum $\mathrm{n}$. So far, specific approaches to assess riks for benthic system sin the Arctic have not been defined.

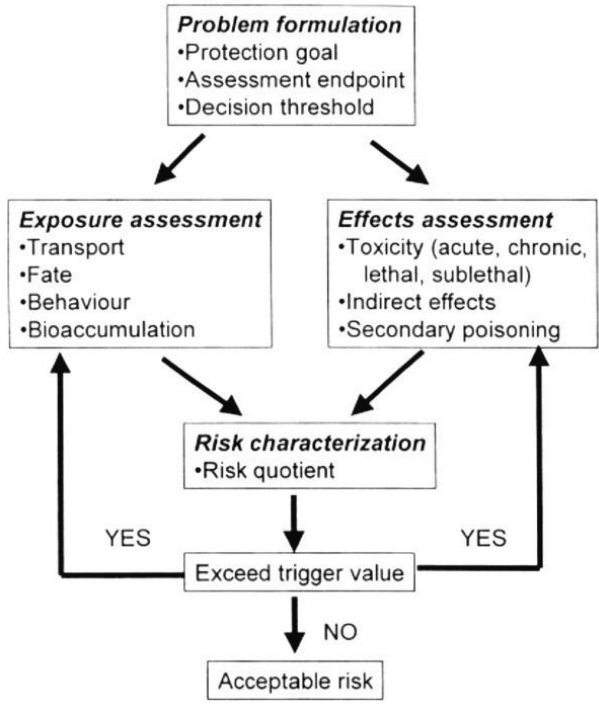

Figure 2. Environm ental risk assessm ent process. Source: Maltby[342].

Current program m es m onitoring the im pacts of O\& $\mathrm{G}$ activities on the Arctic parts of the Norwegian Continental Shelf include the water colum $n$ and benthic habitats[343]. According to the Norwegian Environm ent Agency, both need to be surveyed every three years in both regional and field-specific stations of the sam e geographical region. A m inim um of three wild-caught fish species and caged $\mathrm{m}$ ussels are usually recom $\mathrm{m}$ ended for $\mathrm{m}$ onitoring of exposure and effects in the water colum $\mathrm{n}[343]$. As for the $\mathrm{m}$ onitoring of benthic habitats, only the taxonom ic identification and species density are required. In the Barents Sea, m onitoring of benhic habitats in the Barents Sea South region is planned to start in 2019.

Polycyclic arom atic hydrocarbons (PAHs) are often used as indicators of oil related pollution [14], as petrogenic PAHs are enriched in weathered oil and reside in sedim ent with oit specific chem ical signatures[23,43,120]. Oil does not behave identically to PAHs in the $\mathrm{m}$ arine environm ent, especially when it cocerns fate processes. However, PAHs can be considered a $\mathrm{m}$ ajor fraction contributing to the toxicity of oil. Therefore, in this thesis, several chapters are focused on the behaviour and effects of PAHs (Chapters 2-4), whereas one chapter studies a widely used gas oil; Distillate Marine grade A (DMA; Chapter 5). 


\section{Chapter 6}

As specified before, there is a high need for Arctic specific approaches and m onitoring. To achieve this, the evaluation of environm ental risks of O\& G activities in the Arctic should take into account the specific physiology of Arctic species and environm ental characteristics. Furtherm ore, the uncertainty of exposure pathways of oil related com pounds should be addressed. In this thesis, four potential tools for the m onitoring and risk assessm ent of \&\& $\mathrm{G}$ im pacts on Arctic benthic species were addressed: (1) the use of biotasedim ent accum ulation factors (BSAFs) as indicators for sedim ent PAH bioavailability (Chapters 2,3), (2) the applicability of biom arkers of exposure (Chapter 4) and (3) the suitability of biotransform ation m etabolites in Arctic benthos chronically exposed to PAHs Chapter 4), and (4) the relevance of avoidance tests as a tool for oil im pact assessm ent Chapter 5). These four $m$ ethods were used to identify potential bioindicators for O\&G and shipping related chem ical stress in Arctic coastalbenthic system s. For these tools six research questions were described (Chapter 1), which are discussed below.

\section{Q 1: Can PAH body residues or BSAFs be used as bioavailability indicators in Arctic coastal benthic systems and which target species is most suitable to detect trends?}

In this thesis, bioaccum ulation from sedim ent was evaluated under fieldChapter 2) and laboratory conditions (Chapter 3). The results showed that PAH partitioning deviated from what can be expected from Equilibrium Partitioning Theory (e.g., BSAF having a value of 12 [82]). This was explained by the presence of black carbon in the sedim ent, a bioaccum ulation non-equilibrium, experim ental variability or by any com bination of these factors. This led to both lower and higher BSAF values than the range predicted by the Equilibrium Partitioning Theory.

In the field study (Chapter 2), significantly higher BSAFs were found in individuals from all species collected at a reference area (Blom strandhalvøya) com pared to those collected at a relatively im pacted area ( $\mathrm{Ny}$ Ålesund). This was m ostly ascribed to a higher abundance of black carbon in Ny-Ålesund sedim ent. For the m ajorityof PAH com pounds, body residues differed significantly between species. In Ny-Ålesund, body residues were highest in $M$. calcarea com pared to body residues inA. borealis and $N$. ciliata.

In the laboratory study (Chapter 3), significantly higher BSAFs (i.e., for 3-ring PAHs) and body residues (i.e., for 3- and 4-ring PAHs) were observed in A. borealis than in N. ciliata. This was explained by a difference in feeding activity between these species and by a higher content in black carbon and am orphous organicm atter in the polychaetes than in the bivalves 
sedim ent treatm ent that $\mathrm{m}$ ay have resulted in a lower bioavailability and thus lower PAH uptake in N. ciliata.

In the literature, $\mathrm{m}$ any exam ples apply body residues and/or BSAF values as indicators for bioavailability and bioaccum ulation (e.g., $[56,80,82])$. However, deviations from BSAF values of 1-2 have also been reported frequently, som etim es lim iting the applicability of $\mathrm{BSAF}$ as an unam biguous and reliable m onitoringm etric. This is also seen in the present research, where BSAFs were observed to vary widely. This m eans that the present work confirm $\mathrm{s}$ the lim ited applicability of BSAF values as a relevant $\mathrm{m}$ etric for biom onitoring in the Arctic as well.

As for body residues, also $\mathrm{m}$ any literature reports exist where biom onitoring is based on concentrations in organism s over tim e and space[344,345]. When lipid-norm alised, these concentrations are a m ore pure descriptor of bioavailability and bioaccum ulation as they directly reflect exposure on the individual level. Furtherm ore, body residues can be com pared directly with lipid based toxicity thresholds (e.g., the critical body burden - CBR - concept, see Chapter 2), which is a well-established approach in environm ental risk assessm en[154].

Based on the above, I conclude that PAH body residues provide a $\mathrm{m}$ ore realistic estim ate of the bioavailable PAH fraction than BSAFs. This also im plies that body residues are a better estim ator of exposure in the context of effect and risk assessm ent in Arctic benthic com $\mathrm{m}$ unities than BSAFs. Therefore, body residues are $\mathrm{m}$ ore suitable to deriveetevant environm ental quality standards for Arctic species. However, BSAFs are still useful indicators to help detect possible $\mathrm{m}$ echanism $\mathrm{s}$ affecting body residues, like for instance, variability in organic $\mathrm{m}$ atter com position (e.g., black carbon), biom agnifation and/or non-equilibrium as $\mathrm{m}$ entioned above.

Of all evaluated species I recom m endMacoma calcarea as target species being $\mathrm{m}$ ost suitable to detect trends. This is based on its ability to accum ulate PAHs in low im pacted areas (e.g., Ny-Ålesund), regardless of their body size, and on their selective feeding m ode, which decreases the variability of body residues $m$ easured in the species (Chapter 2). Recently, $M$. calcarea also was suggested as an ecological indicator in the context of developing trait-based approaches to explore changes in rapidly changing ecosystem s[346]. However, in the absence of $M$. calcarea a sim ilar $m$ ethod can be applied to select the next suitable indicator organism, using the criteria from Chapter 1. For instance, Nuculana pernula would be the closest species based on its traits (Chapter 3). 


\section{Chapter 6}

Recommendations. Because of the extensive variability in BSAFs and body residues it is recom $\mathrm{m}$ ended to $\mathrm{m}$ inim ize experim ental variability. This can be achieved by enhancing sedim ent hom ogeneity, representativeness ad uniform ity of test anim als taken from the field, quality and hom ogeneity of food supply, in laboratory tests with Arctic species. Standardized sedim ent toxicity testing [347] can be used to further develop protocols for Arctic benthic testing. A lim iting practical factor is the presence of often less elaborated laboratory facilities for Arctic research that has to be dealt with.

A second recom m endation is to further explore the relation between bioaccum ulation (bdy residues) and environm ental factors (e.g., tem perature, particulate organic carbon, contam inant concentration) through $m$ ultivariate statistical techniques[315,348-350] and based on this develop bioaccum ulationm odels and scenarios for exposure testing

A final recom $m$ endation is to apply the suggested biom onitoring tool, that is, us 1 . calcarea to detect trends and spatial differences in Arctic areas with O\& G related pollution gradients.

Together, this will provide necessary inform ation on spatial and tem poral scales of gradients in bioaccum ulation in the Arctic. When sedim ents need to be sam pled for laboratory exposure experim ents, such inform ation on spatial heterogeneity in chem ical exposure can be used to select sam pling locations for these sedim ents.

\section{Q 2: Can species traits explain differences in PAH bioaccumulationbetween Arctic benthic invertebrates?}

In this thesis, bioaccum ulation was explored for species with different traits under both field (Chapter 2) and laboratory conditions (Chapter 3). The uncertainty in bioaccum ulation m etrics (BSAFs, body residues) was large, especially in the laboratory data. In the field study (Chapter 2), a higher bioaccum ulation of PAHs was observed forM. calcarea in Ny-Ålesund com pared to A. borealis and N. ciliata. This was explained by the high preference for freshly deposited organic $\mathrm{m}$ atter, higher ingestion rate and lower PAH excretion capacity of $M$. calcarea. In the laboratory study (Chapter 3), a lower bioaccum ulationof PAHs was observed for M. calcarea com pared to A. borealis and N. ciliata. This was explained by a general decrease of PAH uptake and $\mathrm{m}$ etabolic rate in $M$. calcarea under laboratory conditions. This decrease of uptake can be explained from the high diet selection of $M$. calcarea [211]. The decrease in $\mathrm{m}$ etabolic rate can possibly be explained from the $\mathrm{m}$ etabolic rate depression experienced by Arctic bivalves during starvation periods [351]. This illustrates 
how laboratory settings can yield quite different results when com pared to observations from field data.

According to the literature, bioaccum ulation is strongly influenced by exposure routes, which in turn are determ ined by species traits, such as the feeding m ode, ingestion- egestion rates, capability to $m$ etabolise chemicals, and diet com position[56,83,274,352,353]. Validated m odels are available to quantify the link between these traits and bioaccum ulation $[56,80,354]$. For Arctic ecosystem s, it has been reported that different benthic groups respond differently to the seasonality in the abundance of organic $m$ atter[127]. However, according to Włodarska-Kowalczuk et al. [355], a relatively high abundance of $\mathrm{m}$ acroalgal detritus in the Kongsfjorden system $\mathrm{m}$ akes benthic organism $\mathrm{s}$ less sensitive to the seasonality in pelagic production. Under such conditions of abundant food supply, differences in bioaccum ulation will be m ostly explained by other factors, such as the species ability to m etabolize and excrete PAHs.

Based on the aforem entioned literature data and data from this thesis, I conclude that bioaccum ulation is also dependent on species traits in Arctic species. The link between species-specific feeding $\mathrm{m}$ ode and bioacum ulation was $\mathrm{m}$ echanistically explained using m odels (Chapter 3). However, the m odel's statistical significance rem ained lim ited as com pared to earlier m odel evaluations, because of the considerable residual error between observations and m odel predictions.

Recommendations. Because of the high variability in BSAFs and body residues, it is recom $m$ ended to reduce experim ental variability. This will increase the rigour of tests that aim to detect differences in bioaccum ulation am ong species with different tratis, as well as the significance of $\mathrm{m}$ odels aim ed at $\mathrm{m}$ echanistically explaining the observations.

To be able to explain differences in bioaccum ulation am ong species from the field, the characteristics relating to quality and quantity of organic $m$ atter in alldifferent diet com ponents (e.g., sedim ent and freshly deposited organic $m$ atter) need to be determ ined. This includes quantifying organic $m$ atter, black carbon, oil and other possible solid com ponents involved in binding hydrophobic chem icals.

Finally, it is recom m ended to assess bioaccum ulation for a wider range of species in the field, together with com m unity com position and sedim ent characteristics at the sites of interest. This will allow to study bioaccum ulation patterns over tim e and space, for a m uchvider 


\section{Chapter 6}

range of species traits, including im proved opportunities for $\mathrm{m}$ echanistic $\mathrm{m}$ odelling. Furtherm ore, this allows for establishing causal relationships between bioaccum ulation and com m unity com position் situ.

\section{Q 3: Does bioaccumulation of PAH s differ betveen Arctic and temperate benthic} invertebrate species with different traits, and can modelling assist in reading across between species?

In $\mathrm{m}$ y research, no significant differences were observed in PAH body residues and BSAFs between Arctic and tem peratebenthic species under laboratory conditions (Chapter 3). This was $m$ ainly due to the substantial biological variability in the data.

Little is known about bioaccum ulation of PAHs from sedim ent by Arctic benthic species, com pared to bioaccum ulation by temqrate species. To $\mathrm{m}$ y understanding, no studies have been published on the direct com parison of bioaccum ulation by Arctic versus tem perate benthic species. Two studies report PAH body residues in Arctic benthic species $[121,356]$. One of these studies included the m odelling of bioaccum ulation factors (BAFs) in blue $\mathrm{m}$ ussels obtained from literature to infer sea water concentrations[121]. In this sense, this study (Chapter 3) is the first attem pt to com pare and to m odel bioaccum ulation in sim ilar Arctic and tem perate benthic species.

Hypotheses were provided based on published differences in species traits with relevance for bioaccum ulation. For instance, feeding rate, clearance rate and digestion rates often are lower in Arctic species [213,357,358], that $\mathrm{m}$ ay affect both bioaccum ulation and risks.These differences were not observed in our experim ents, due to the fact that they were probably sm aller than the current variability in the data (Chapter 3).

For tem perate species, the use of biodynam ic m odelling has helped to provide a m echanistic understanding of bioaccum ulation processes $[56,83]$. The m odels can also be used to predict PAH bioaccum ulation in the absence of experim ental data[203], and to read across species, com partm ents (freshwatens $m$ arine) and potentially clim ate regions. Exan ples of m odelling of contam inants across tem perate and Arctic pelagic species are provided by som e studies $[359,360]$. These studies concluded that bioaccum ulation in the Arctic $m$ ay be described in the sam e way asbioaccum ulation in tem perate regions. In this thesis, however, dynam ic sim ulations am ong species with sim ilar traits and exposed to PAHs under laboratory conditions did not reveal any clear differences in the m odel param eters between species or 
tests. This was due to the substantial variability in the biological control data and the sim ilarity in exposure routes (Chapter 3).

Despite the lack of significant differences in PAH bioaccum ulation between Arctic and tem perate species in our study, I argue that differences between Arctic and tem perate species can be detected if $\mathrm{m}$ ore rigorous testing $\mathrm{m}$ ethods are applied in these tests, and/or if other selections of species, individuals or sedim ents would be used in these tests.

Recommendations. As specified above, there is a need to im prove the accuracy of bioaccum ulation testing. This can be achieved by a series of m easures, such as the use of non exposed test anim als, artificial sedim ent, a higher num ber of replicates and tim e points, and/or a m ore constant food addtion.

These im provem ents will also increase the applicability of bioaccum ulation m odels and lead to $m$ ore certain param eter values. Additionally, several m odel param eters need to be $m$ easured in an experim ental set up, in order to increase the reliabilityof bioaccum ulation m odels for Arctic species (such as growth and feeding rates of species). To get a better understanding when com paring Arctic and tem perate species, specific tests can be done where sedim ents either are identical for both Arctic and tem perate species, or a suitable representative of the region's sediment type. The tests can be done with Arctic and temperate species at the same tem perature, or at tem peratures specific to Arctic and tem perate conditionsThis way the relative im portance of bth tem perature and sedim ent properties can be identified which helps to further elucidate potential differences am ong species and regions.

\section{Q 4: What is the feasibility of using biomarkers of exposure to monitor PAH pollution in} the Arctic? Is the identification of biotransformation metabolites a better alternative?

For an integrated $\mathrm{m}$ onitoring and assessm ent program $\mathrm{m}$ e for the Arctic, biom arkers and bioassays need to be tested and validated in Arctic organism $\mathrm{s}$ that are representative for the water and sediment com partm enf 91,361$]$. For the benthic com partm ent, benthic invertebrates $m$ ay fulfil the role of bioindicators of chem ical pollution, just as fish species do for the water com partm en $\{343,362]$. In this respect it is essential to causally link chem ical body residues and biom arkers m easured at different suborganism al levels (Figure 3), in order to increase the interpretative value of individual $m$ easurem ents[345]. Therefore, in $m$ y study, I analysed both PAH body residues and biom arkers of exposure/effect in target species. 


\section{Chapter 6}

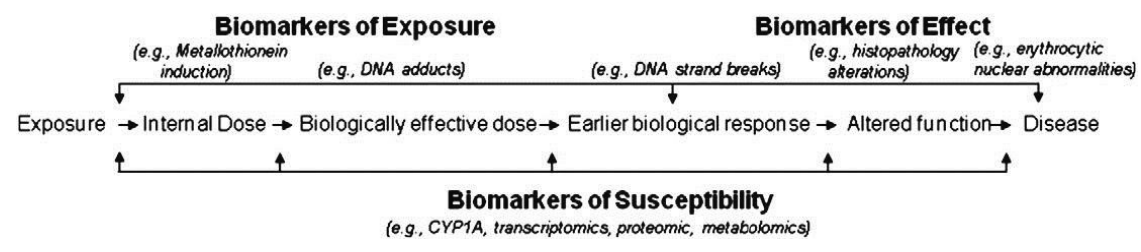

Figure 3. Continuum from chem ical exposure to organism level effectSource: Chapm an et al. [363].

For an integrated exposure an effect assessm ent (Figure 2), two biom arkers of PAH exposure (i.e., acyl-CoA oxidase [AOX] and glutathione S-transferase [GST]) and one biom arker of neurotoxicity (i.e., acetylcholinesterase [AChE]) in A. borealis were addressed (Chapter 4). GST and AChE have been validated in tem perate bivalves before. They are com m only used in the assessm ent of oil im pac [364] and pollution m onitoring[365], whereas AOX generally shows a rapid response to PAH exposure in tem perate bivalves[279,281]. In the present work, interpretation of enzym atic biom arkers data inA. borealis was lim ited. This is because either baseline studies are lacking for Arctic benthic species [215], or these biom arkers were assessed in water exposed rather than sedim ent exposed Arctic benthic organism \$3666,367].

Pyrene $\mathrm{m}$ etaboltes, and particularly 1-hydroxypyrene, have been used before as a suitable biom arker of PAH exposure in tem perate species[368,369]. Our study $m$ ade the first $m$ ulti species com parison of pyrene biotransform ation beween Arctic and tem perate benthic invertebrates (Chapter 4). This was done to estim ate differences in their biotransform ation capacity as well as to validate the use of 1-hydroxypyrene and pyrene-1-glucuronide [183] as biom arkers of PAH exposure in Arctic species.

Unlike pyrene body residues, a significant increase in the concentration of pyrene-1glucuronide was observed in polychaetes exposed to the high sedim ent treatm ent com pared to the low sedim ent treatm ent Chapter 4). This increase was not detected in bivalve species. In polychaetes, biotransform ation rates did not vary between treatm ents in our study. This was illustrated by the sim ilar relative conœntrations of pyrene-1-glucuronide in polychaetes exposed to the different sedim ent treatm ents, im plying biotransform ation also at low concentrations. As for enzym atic biom arkers, there was no correlation between the activity of biom arkers in A. borealis and PAH contam ination levels in sedim ent treatm ents(Chapter 4). This could $\mathrm{m}$ ainly be explained by the low PAH contam ination levels inA. borealis, although the influence of confounding factors $[134,283]$ could not be excluded. There is a lack of 
knowledge on pyrene m etabolites in Arctic invertebrates and the use of biom arkers in Arctic invertebrates in general $[213,370]$.

Based on the available literature data and data from this thesis, I conclude that the analysis of pyrene $\mathrm{m}$ etabolites provides a feasible approach toassess PAH exposure in Arctic benthic populations. However, it would be advisable to review the sensitivity of additional biom arkers of exposure and biom arkers ofeffect in order to develop a further weight-of-evidence approach.

Recommendations. In order to provide a m ore robustand integrated assessm ent of PAH exposure in Arctic species, the ability of different $m$ arkers of exposure needs to be evaluated to provide an early warning of risks on PAH m ediated biological effects. This can be achieved by exploring the relative effect of environm ental and biological factors on the activity of biom arkers with respect to PAH exposure[275]. The natural $m$ etabolic activity and seasonal dynam ics of biom arkers in Arctic species are needed to be able to determ ine relevant biom arker responses in Arctic benthic invertebrates to PAH exposure in the field. Finally, our findings illustrate that Arctic benthic m acroinvertebrates have a biotransform ation capacity, which should not be overlooked when evaluating accum ulation and risks of PAHs in the Arctic [93,94].

\section{Q 5: Can behavioural tests like avoidance behaviour become a suitable monitoring tool for oil impact assessment in the Arctic?}

In $\mathrm{m}$ y research, a significant avoidance of DMA oilspiked sedim ent was observed at 1000 $\mathrm{m} \mathrm{g} / \mathrm{kg}$ (dry weight). Furtherm ore, it was shown that for the freshwater speciesG. pulex this occurred within an exposure tim e of $96 \mathrm{~h}$, whereas for the $\mathrm{m}$ arine species $G$. locusta in one of two tests, this occurred within an exposure tim e of $72 \mathrm{~h}$ (Chapter 5). Hence, this shows that the tests are able to detect behavioural effects of gam m arids toDMA oil, as well as a tim e dependency of these effects.

Differences in tim e dependency of avoidance behaviour between the two species, were explained by the experimental conditions (i.e., water parameters, feeding) on the species' sensitivities to DMA oil and to their ability to $\mathrm{m}$ aintain active over tim e. The sensitivity to detect DMA oil was explained by a higher ventilation rate, caused by the exposure of G. pulex at its upper therm al tolerance $\lim$ it (i.e., $15^{\circ} \mathrm{C}$ ). As for $\mathrm{G}$. locusta, the ability to detect and 


\section{Chapter 6}

avoid DMA $m$ ay have been restricted by a higher salinity in the $m$ arine experim ents and low feeding potential.

Within-species differences in the avoidance response of G. locusta am ong tests were considerable, thereby lim iting the rigour of the test (Chapter 5). This variability $m$ ay have been related to the variability am ong individuals used in the tests. This originates from differences in structural growth and reproductive status of the tested individuals, as observed $\mathrm{m}$ ore often am ong sum $\mathrm{m}$ er. locusta generations [327,329].

In the literature, behavioural endpoints such as the avoidance response to oil of benthic organism s have been proposedbefore as a tool to detect sublethal effects of oil in sedim ent [99,304-306]. Studies on the avoidance behaviour of oil-contam inated sedim ent by tem perate $\mathrm{m}$ arine am phipod\$298] and of PAH-spiked sedim ent by tem perate freshwater invertebrates [100] showed that avoidance behaviour was not affected by the background exposure history of the organism s to either oil or PAHs, and that avoidance tests could be used as an alternative to chronic toxicity testing. These studies also concluded that hom ogeneity in exposure conditions (e.g., sedim entcharacteristics, feeding) or in test species individuals is crucial. Variability am ong individuals $\mathrm{m}$ ay be less for Arctic species than for tem perate species. Variability in energy levels of organism s is likely to affect avoidance behaviour[322,371]. Energy levels are affected by environm ental factors (e.g., tem perature and salinity[335,372]) and biological variables (e.g., structural growth rate $[313,333,372]$ and reproductive status [327,329,372]). Som e Arctic benthic m arine am phipods (e.g.Gammarus setosus) show less variability than $G$. locusta with regards to a longer life-span and fewer reproductive events [373]. Based on this, G. setosus $\mathrm{m}$ ay be a suitable candidate species for effective avoidance tests for Arctic sedim ents exposed to oil.

Given the above, I conclude that avoidance tests are suitable for $\mathrm{m}$ onitoring oil im pact in tem perate regions, whereas their applicability in the Arctic is likely but needs $m$ ore investigation.

Recommendations. The avoidance tests need to be validated with Arctic species under Arctic conditions prior to im plem entation.

I suggest the use of im $\mathrm{m}$ ature adultG. setosus collected during early spring for the avoidance tests (i.e., March-April) [373]. During this period, G. setosus synchronizes its activity with the 
spring bloom [374,375] and water param eters are stable[62]. Im $\mathrm{m}$ ature adults will lim it its energy allocation to acclim ation andgrowth, and start building up energy reserves.

Finally, several aspects of the test conditions can be further im proved. For instance, sedim ent oxygen dem and $\mathrm{m}$ ay be used to evaluate the physiological state of individuals during tests, and the applicability of these tests at low PAH exposure level $[104,259]$. Sim ilarly, the hom ogeneity of sedim ent characteristics and feeding can be considered for an optim ised test.

\section{Q 6: What are prospects and advantages of using Arctic benthic bioindicator species for monitoring long-term impacts of $O \& G$ and other maritime activities in the Arctic?}

Here the prospects and advantages of using Arctic benthic bioindicator species are discussed based on the criteria provided in Chapter 1:

1. Its response is sensitive to changes in the chem ical concentration;

2. Its response is specific and causally related to the chem ical exposure;

3. Its response is adequate given the anticipated concentration of the chem ical;

4. The species' uptake/elimination of the chem ical can be quantified;

5. The toxic effects of the chem ical can be m easured/interpreted.

These criteria, based on Goodsell et al. [19], do not necessarily need to apply to every single aspect $m$ easured on a bioindicator species. For instance, $m$ easuring a biom arker of exposure can be $\mathrm{m}$ eaningful in the context of biom onitoring, even without $\mathrm{m}$ easuring the response of a biom arker of effect (criterion 3).

As for the first two criteria, the correlation between bioaccum ulation of PAHs and PAH exposure levels was tested for species with different traits under field conditions (Chapter 2). It was suggested that exposure was lower in the presence of black carbon, thus im plying a positive correlation between exposure and uptake. However, the causality of bioaccum ulation changes could also be explained by the species' feeding traits as was shown under experim ental conditions (Chapter 3). In that respect, $M$. calcarea can be used to detect spatial and tem poral gradients in bioaccum ulation in the Arctic due to its selective feeding m ode (Q 1).

As for the third criterion, confounding non-target chem icals or environm ental conditions have to be taken into account. The causality of the interrelationships between biom arkers at different suborganism al levels needs to be established for the bioindicator candidates (Figure 3 ; [376]). This is needed for the validation of the bioindicator species as these relationships will be used to select appropriate biom arkers which can provide early warning/are indicative 


\section{Chapter 6}

of PAH biological effects. In $\mathrm{m}$ y research, a direct causality between the concentration of pyrene body residue and the rate of pyrene biotransform ation was not found in M. calcarea (Chapter 4).

In addition, for the actual validation of $M$. calcarea as a biom onitoring species, future studies should address the com bined effects of relevant oil chem ical com ponents and environm ental factors on biom arker responses[361]. Although a long-term strategy is essential for such studies [377], the use of Arctic region specific environm ental quality standards in an integrated $\mathrm{m}$ onitoring and assessm ent program $\mathrm{m} e$ is essential for the understanding of the dynam ics of toxicants and their effects on Arctic m arine ecosystem [345]. This im plies that m uch work is still needed (e.g., seeQ 4 ) and that the present study is only a first start for what is needed to fully develop a validated system for biom onitoring in the Arctic.

The adaptation of existing $\mathrm{m}$ ethodology to Arctic species and conditions $\mathrm{m}$ ay form ausitable base for the environm ental risk assessm ent of O\& G and shipping activities in the Arctic, and the use of Arctic benthic bioindicator species is feasible and highly necessary for the prediction of long-term im pacts of such activities on Arctic benthi habitats.

\section{Conclusion}

For the selection of relevant bioindicators for O\& $\mathrm{G}$ im pact assessm ent in the Arctic, sedim ent tests can be used in com bination with chem ical data and biom arkers $m$ easured in the organism collected in situ as part of an integrated weight-of-evidence approach. Bioaccum ulation testing requires the im plem entation of $\mathrm{m}$ ore standardized $\mathrm{m}$ ethods for sedim ent preparation, exposure conditions and acclim atization of field organism s Q 3). A better understanding of the natural variability in biom aker responses in Arctic species is also needed in com bination with the influence of environm ental confounding factors $(\mathbf{Q} 4)$.

With a few exceptions, it is not com $\mathrm{m}$ on to find all properties of a good bioindicator in one single species. Thus, different species $m$ ay be used inthe evaluation of different sublethal endpoints. This also accounts for the selection of biom arkers. A single biom arker response is generally not adequate, but a suite of biom arkers can be used to indicate early effects of exposure (as in this thesis) and/or effects of a toxicant. Biom arkers present early warning inform ation that biodiversity indicators, such as biotic indexes, do not offer. Biom arkers of exposure are closely related to chem ical stress, while biodiversity indicators are notspecific 
and $m$ ay indicate all kinds of different stressors. Hence, biom arkers $m$ ay enable $m$ itigation $\mathrm{m}$ easures before irreversible im pacts occur.

In this thesis, M. calcarea was selected as a potential bioindicator species for $\mathrm{O} \& \mathrm{G}$ im pact assessm ent in theArctic (Q 2). In short, M. calcarea was able to accum ulate PAHs at a low exposure level under field conditions, although the species showed a variable level of pyrene $m$ etabolization under laboratory conditions. This was m ostly related to experim ental conditions, but potentially also to the likely variability in the physiological state of $M$. calcarea individuals. Its capacity for the excretion of PAH m etabolites was low. Although the actual $\mathrm{m}$ etabolization and excretion of PAHs still need to be further tested,the retention of PAH m etabolites at a low exposure level in $M$. calcarea $\mathrm{m}$ akes it worthwhile to study the im plem entation of several biom arkers with tem poral differences in their response and differences in their effective dose.

A bioindicator like $M$. calcarea could be incorporated into a signalling system . Signalling system s can be seen as a weightof-evidence approach, being an integrative index based on biom arkers that allow us to classify sam pling sites with respect to their pollution status. For instance, the Integrated Biom arker Response (IBR)[378] is a $m$ athem atical tool based on biom arker data standardisation and their aggregation into a single value. Other approaches like the Integrated assessm ent of hazardous substances in the Baltic Sea (CHASE tool) com bine chem ical ad biological $\mathrm{m}$ easurem ents. Such approaches $\mathrm{m}$ ay reduce the uncertainty in interpretation of biom arker responses and can be used for regular and im pactspecific biom onitoring.

A crucial part of such a signalling system is a solid knowledge on the baselinelevels. Such baseline studies need to characterize natural levels in PAH body residues and biom arker responses com $\mathrm{m}$ only recom $\mathrm{m}$ ended for biom onitoring and to evaluate the sensitivity to oil pollution in these Arctic species. Furtherm ore, baseline studies hdp to identify the strengths and lim itations for application of biom arkers to (sub)Arctic regions as well as to determ ine their seasonal variability in potential bioindicator species. Seasonality $\mathrm{m}$ ay result in particular physiological characteristics of Arctic species that affect their toxic response to oil and PAHs (e.g., seasonality in lipid reserves). In addition, environm ental fluctuations in the light regim e and tem perature $m$ ay affect the bioavailability and exposure to oitrelated chem icals. Baseline studies using bioindicator species will help to better characterize the general $\mathrm{m}$ echanism $\mathrm{s}$ and patterns underlying negative effects of $\mathrm{O} \& \mathrm{G}$ and shipping activities. 


\section{Chapter 6}

The overall utility of this work consists of a first evaluation of prom ising candidate species for Arctic biom onitoring and research program $\mathrm{m}$ es, and of various alternative approaches for the early identification of negative ecological im pacts of O\& G and shipping in Arctic benthic bioindicators.

Particularly, this thesis proposed one potential benthic bioindicator species (M. calcarea) and one potential tool (avoidance tests) for the assessm ent of oil im pacts on sedim ent for its further validation under Arctic conditions. It also underlined the need for standard sedim ent test protocols and baseline studies as an integral part of environm ental risk assessm ent in the Arctic, and provided several recom m endations based on existing guidelines and a com parative study of bioaccum ulation data from field and laboratory studies with Arctic species. 


\section{List of references}

1. Larsen JN, Anisim ov OA, Constable A, Hollowed AB, Maynard N, Prestrud P, et al. Polar regions. Clim ate change 2014: Im pacts, adaptation, and vulnerability Part B: Regional aspects contribution of working group II to the fifth assessm ent report of the Intergovernm ental Pand on Clim ate Change. Cam bridge United Kingdom): Cam bridge University Press 2014; p. 1567-612.

2. Grebm eier JM. Shifting patterns of life in the Pacific Arctic and sub-Arctic seas. Annual Review of Marine Science. 2012;4:63-78.

3. Krause-Jensen D, Duarte CM. Expansion of vegetated coastal ecosystem s in the future Arctic. Frontiers in Marine Science. 2014 Decem ber17, 2014;1(77).

4. ICES. Final Report of the Working Group on the Integrated Assessm ents of the Barents Sea (WGIBAR). Murm ansk (Russia): International Council for the Exploration of theSea. 2016 February 22-26, 2016.

5. Lien T. The world needs a stable oil m arket. Norwegian Ministry of Petroleum and Energy 2016.

6. Gelcich S, Buckley P, Pinnegar JK, Chilvers J, Lorenzoni I, Terry G, et al. Public awareness, concerns, and priorities about anthropogenic im pacts on $\mathrm{m}$ arine environm ents. Proceedings of the National Academ y of Sciences. 2014 October 21, 2014;111(42):15042-7.

7. Gulas S, Downton M, D'Souza K, Hayden K, Walker TR. Declining Arctic Ocean oil and gas developm ents: Opportunities to im prove governance and environm ental pollution control. Marine Policy. 2017;75:53-61.

8. Peterson CH, Rice SD, Short JW, Esler D, Bodkin JL, Ballachey BE, et al. Long-term ecosystem response to the Exxon Valdez oil spill. Science. 2003;302(5653):2082-6.

9. Atlas RM, Hazen TC. Oil biodegradation and biorem ediation: A tale of the two worst spills in U.S. history. Environm ental Science \& Technology. 201145(16):6709-15.

10. Schm idt CW. Arctic oil drilling plans raise environm ental health oncerns. Environm ental Health Perspectives. 2011;119(3):A116-A7.

11. Com er B, Olm er N, Mao X. Heavy fuel oil se in Arctic shipping in 2015. The International Council on Clean Transportation. 2016.

12. Sørstrøm SE, Brandvik PJ, Buist I, Daling P, Dickins D, Faksness L-G, et al. Joint industry program on oil spill contingency for Arctic and ice-covered waters. 2010; 32 Contract No.: 978-82-14-04759-2.

13. Thorsell DE, Leschine TM. An evaluation of oil pollution prevention strategies in the Arctic: A com parison of Canadian and U.S. approaches. Marine Policy. 2016;72:255-62.

14. AMAP. Assessm ent 2007: Oil and Gas Activities in the Arctic- Effects and Potential Effects. Arctic Monitoring and Assessm ent Program m.e2010.

15. Kristoffersen B, O'Brien K, Selboe E. Opportunistic adaptation. The adaptive challenge of clim ate change. Cam bridge(United Kingdom): Cam bridge University Press 2015; p. 118-39.

16. Nevalainen M, Helle I, Vanhatalo J. Preparing for the unprecedented - Towards quantitative oil risk assessm ent in the Arctic m arine areas. Marine Pollution Bulletin. 2017;114(1):99101.

17. Hauge KH, Blanchard A, Andersen G, Boland R, Grøsvik BE, Howell D, et al. Inadequate risk assessm ents- A study on worst-case scenarios related to petroleum exploitation in the Lofoten area. Marine Policy. 2014;44(Supplem ent C):82-9. 


\section{List of references}

18. Blanchard A, Hauge KH, Andersen G, Fosså JH, Grøsvik BE, Handegard NO, et al. Harm ful routines? Uncertainty in science and conflicting views on routine petroleum operations in Norway. Marine Policy. 2014;43:313-20.

19. Goodsell PJ, Underwood AJ, Chapm an MG. Evidence necessary for taxa to be reliable indicators of environm ental conditions or im pacts. Maime Pollution Bulletin. 2009;58(3):323-31.

20. IOGP. Environm ental fates and effects of ocean discharge of drill cuttings and associated drilling fluids from offshore oil and gas operations. International Assodation of Oil and Gas Producers. 2016; Report No. 543.

21. U.S.E.P.A. Final Ocean Discharge Criteria Evaluation of the Arctic NPDES General Perm it for Oil and Gas Exploration (Perm it No. AKG280000). Seattle, WA: U.S. Envirom ental Protection Agency, Region 10. 2006.

22. Neff JM, Lee K, DeBlois EM. Produced Water: Overview of Com position, Fates, and Effects. In: Lee K, Neff JM, editors. Produced Water: Environm ental Risks and Advances in Mitigation Technologies. 1 ed: Springer-Verlag New York. 2011; p. 3-54.

23. Bakke T, Klungsøyr J, Sanni S. Environm ental im pacts of produced water and drilling waste discharges from the Norwegian offshore petroleum industry. Marine Environm ental Research. 2013;92:1549.

24. Neff JM. Bioaccum ulation in Marine Organism s: Effects of Contam inants from Oil Well Produced Water. Am sterdam (The Netherlands): Elsevier B.V. 2002.

25. NRPA. Natural Radioactivity in Produced Water from the Norwegian Oil and Gas Industry in 2003. Østerås (Norway): Norwegian Radiation Protection Authority. 2004; Strålevern Rapport 2005:2.

26. Zheng J, Chen B, Thanyam anta W, Hawboldt K, Zhang B, Liu B. Offshore produced water $\mathrm{m}$ anagem ent: A review of current practice and challenges in harsh/Arctic environm ents. Marine Pollution Bulletin. 2016;104(1-2):7-19.

27. Holth TF, Beckius J, Zorita I, Cajaraville MP, Hylland K. Assessm ent of lysosom al m em brane stability and peroxisom e proliferation in the head kidney of Atlantic cod (Gadus m orhua) following longterm exposure to produced water com ponents. Marine Environm ental Research. 2011;72(3):12734.

28. Geraudie P, Nahrgang J, Forget-Leray J, Minier C, Cam us L. In vivo effects of environm ental concentrations of produced water on the reproductive function of polar cod (Boreogadus saida). Journal of Toxicology and Environm ental Health- Part A: Current Issues. 2014;77(9-11):557-73.

29. Jensen LK, Halvorsen E, Song Y, Hallanger IG, Hansen EL, Brooks SJ, et al. Individual and m olecular level effects of produced water contam inants on nauplii and adult fem ales of Calanus finm archicus. Journal of Toxicology and Environm ental Health, Part A. 2016;79(13-15):585-601.

30. Wassm ann P, Reigstad M, Haug T, Rudels B, Carroll ML, Hop H, et al. Food webs and carbon flux in the Barents Sea. Progress in Oceanography. 2006;71(2-4):232-87.

31. Montagna PA, Baguley JG, Cooksey C, Hyland JL. Persistent im pacts to the deep softbottom benthos one year after the Deepwater Horizon event. Integrated Environm entalAssessm ent andManagem ent 2016.

32. Harm an C, Thom as KV, Tollefsen KE, Meier S, Bøyum O, Grung M. Monitoring the fely dissolved concentrations of polycyclic arom atic hydrocarbons (PAH) and alkylphenols (AP) around a Norwegian oil platform by holistic passive sam pling. Marine Pollution Bulletin. 2009;58(11):16719.

33. Beyer J, Myhre LP, Sundt RC, Meier S, Tollefsen K-E, Vabø R, et al. Environm ental risk assessm ent of alkylphenols from offshore produced water on fish reproduction. Marine Environm ental Research. 2012;75:29.

34. Wassm ann P, Reigstad M. Future Arctic Ocean seasonal ice zones and im plications for pelagic-benthic coupling. Oceanography. 2011;24(3):220-31. 
35. Søreide JE, Carroll ML, Hop H, Am brose WG, Hegseth EN, Falk-Petersen S. Sym pagicpelagic-benthic coupling in Arctic and Atlantic waters around Svalbard revealed by stable isotopic and fatty acid tracers. Marine Biology Research. 2013;9(9):831-50.

36. Kędra M, Moritz C, Choy ES, David C, Degen R, Duerksen S, et al. Status and trends in the structure of Arctic benthic food webs. Polar Research. 2015;34(23775).

37. Frey KE, Com iso JC, Cooper LW, Gradinger RR, Grebm eier JM, Trem blay JÉ. Arctic Ocean Prim ary Productivity. Arctic Essays [Internet]. 2016. Available from :http:/www.arctic.noaa.gov/Report-Card/ReportCard-2016/ArtMID/5022/ArticleID/284/Arctic-Ocean-Prim ary-Productivity.

38. Pörtner HO, Peck L, Som ero G. Therm al lim its and adaptation in m arine Antarctic ectotherm s: an integrative view. Philosophical Transactions of the Royal Society B: Biological Sciences. 2007;362(1488):223358.

39. Richard J, Morley SA, Deloffre J, Peck LS. Therm al acclim ation capacity for four Arctic $\mathrm{m}$ arine benthic species. Journal of Experim ental Marine Biology and Ecology. 2012;424-425:38-43.

40. Jørgensen LL, Ljubin P, Skjoldal HR, Ingvaldsen RB, Anisim ova N, Manushin I. Distribution of benthic $m$ egafauna in the Barents Sea: baseline for an ecosystem approach to m anageme. 2014 July 2, 2014.

41. CAFF. Arctic Marine Biodiversity Monitoring Plan Annual Report 2016: Annual report on the im plem entation of the CBMP's Arctic Marine Biodiversity Monitoring Plan. 2016.

42. Olsen E, Holen S, Hoel AH, Buhl-Mortensen L, Røttingen I. How integrated ocean governance in the Barents Sea was created by a drive for increased oil production. Marine Policy. 2016;71:293-300.

43. Jonker MTO, Brils JM, Sinke AJC, Murk AJ, Koelm ans AA. Weathering and toxicity of m arine sedim ents contam inated with oils and polycyclic arom atic hydrocarbons. Environm ental Toxicogy and Chem istry. 2006;25(5):1345-53.

44. Ma Y, Xie Z, Yang H, Möller A, Halsall C, Cai M, et al. Deposition of polycyclic arom atic hydrocarbons in the North Pacific and the Arctic. Journal of Geophysical Research: Atm ospheres. 2013;118(11):5822-9.

45. Yunker MB, Macdonald RW. Com position and origins of polycyclic arom atichydrocarbons in the Mackenzie river and on the Beaufort Sea shelf. Arctic. 1995;48(2):118-29.

46. Jonker MTO, Sinke AJC, Brils JM, Koelm ans AA. Sorption of polycyclic arom atic hydrocabons to oil contam inated sedim ent: Unresolved om plex? Environm ental Science \& Technology. 2003;37(22):519-203.

47. NRC. Oil in the Sea III : Inputs, Fates, and Effects. Washington, DC: National Research Council. 2003; $280 \mathrm{p}$.

48. Moerm ond CTA, Roessirk I, Jonker MTO, Meijer T, Koelm ans AA.Im pact of polychlorinated biphenyl and polycyclic arom atic hydrocarbon sequestration in sedim ent on bioaccum ulation in aquatic food webs. Environm ental Toxicology and Chem istry. 2007;26(4):60715.

49. Payne JR, McNabb GD, Clayton JR. Oil-weathering behavior in Arctic environm ents. Polar Research. 1991;10(2):631-62.

50. Brandvik PJ, Faksness L-G. Weathering processes in Arctic oil spills: Meso-scale experim ents with different ice conditions. Cold Regions Science and Technology. 2009;55(1):160-6.

51. Brown KE, King CK, Kotzakoulakis K, George SC, Harrison PL. Assessing fuel spill risks in polar waters: Tem poral dynam ics and behaviour of hydrocarbons from Antarctic diesel, $\mathrm{m}$ arine gas oil and residual fuel oil. Marine Pollution Bulletin. 2016;110(1):343-53. 


\section{List of references}

52. Crisafi F, Giuliano L, Yakim ov MM, Azzaro M, Denaro R. Isolation and degradation potential of a cold-adapted oil/PAH-degrading $\mathrm{m}$ arine bacterial consortium from Kongsfjorden (Arctic region)Rendiconti Lincei. 2016;27(1):261-70.

53. Koelm ans AA, Poot A, Lange HJD, Velzeboer I, Harm sen J, Noort PCMvEstim ation of in situ sedim entto-water fluxes of polycyclic arom atic hydrocarbons, polychlorobiphenyls and polybrom inated diphenylethers. Environm ental Science \& Techology. 2010;44(8):3014-20.

54. Rakowska MI, Sm it MPJ, Kupryianchyk D, Qin J, Koelm ans AA, Rijnaarts HHM, et al. Turbulent $\mathrm{m}$ ixing accelerates PAH desorption due to fragm entation of sedim ent particle aggregates. Journal of Soils and Sedim ents. 2017;17(1):277-85.

55. Jonker MTO, Koelm ans AA. Sorption of polycyclic arom atic hydrocarbons and polychlorinated biphenyls to soot and soot-like $\mathrm{m}$ aterials in the aqueous environm ent: Mechanistic onsiderations. Environm ental Science \& Technology. 2002;36(17):3725-34.

56. Diepens NJ, Van den Heuvel-Greve MJ, Koelm ans AA.Modeling of bioaccum ulation in $m$ arine benthic invertebrates using a $\mathrm{m}$ ultispecies experim ental pproach. Environm ental Science \& Technology. 2015;49(22):13575-85.

57. Neff JM. Chapter 15 - Polycyclic Arom atic Hydiocarbons in the Ocean. Bioaccum ulation in Marine Organism s: Effect of Contam inants from Oil Well Produced Water. Oxford: Elsevier2002; p. 241-318.

58. Varanasi U. Metabolism of Polycyclic Arom atic Hydrocarbons in the Aquatic Environm ent: CR Press. $1989 ; 352 \mathrm{p}$.

59. Benedetti M, Martuccio G, Fattorini D, Canapa A, Barucca M, Nigro M, et al. Oxidative and m odulatory effects of trace $m$ etals on m etabolism of polycyclic arom atic hydrocarbons in the Antarctic fish Trem atom us bernacchii. Aquatic Bxicology. 2007;85(3):167-75.

60. Yang Z, Feng J, Niu J, Shen Z. Release of polycyclic aromatic hydrocarbons from Yangtze iiver sedim ent cores during periods of sim ulated resuspension. Environm ental Pollution. 2008;155(2):3664.

61. Oh S, Wang Q, Shin WS, Song D-I. Sorption and desorption kinetics of PAHs in coastal sedim ent. Korean Journal of Chem ical Engineering. 2013;30(1):145-53.

62. Beuchel F, Gulliksen B. Tem poral patterns of benthic com m unity developm ent in an Arctic fjord (Kongsfjorden, Svalbard): results of a 24-year m anipulation study. Polar Biology. 2008;31(8):913-24.

63. MacArthur RH, Wilson EO. The Theory of Island Biogeography: Princeton University Press. 2001.

64. Moe SJ, De Scham phelaere K, Clem ents WH, Sorensen MT, Van den Brink PJ, Lèss M. Com bined and interactive effects of global clim ate change and toxicants on populations and com $\mathrm{m}$ unities. Environm ental Toxicology and Chem istry / Setac. 2013;32(1):49-61.

65. Neff JM. Fates and Effects of Water Based Drilling Muds and Cuttings in Cold-Water Environm ents. Duxbury, MA: Neff \& Associates LLC. 2010.

66. OSPAR. OSPAR List of Substances Used and Discharged Offshore which Are Considered to Pose Little or No Risk to the Environm ent (PLONOR). OSPAR Agreem ent 201306 ed2004.

67. OSPAR Decision 2000/2 on a Harm onised Mandatory Control System for the Use and Reduction of the Discharge of Offshore Chem icals (as am ended by OSPAR Decision 2005/1.) 2000.

68. NME. Integrated Managem ent of the Marine Environm ent of the Barents Sea and the Sea Areasoff the Lofoten Islands. Oslo (Norway): Norwegian Ministry of the Environm ent.2006.

69. Renaud PE, Jensen T, Wassbotten I, Mannvik HP, Botnen H. Offshore sedim ent m onitoring on the Norwegian shelf: A regional approach 1996-2006. Trom sø (Norway): Akvaplanniva AS. 2008. 
70. De Hoop L, Schipper AM, Leuven RSEW, Huijbregts MAJ, Olsen GH, Sm it MGD, et al. Sensitivity of polar and tem perate $\mathrm{m}$ arine organism $\mathrm{s}$ to oil com ponents. Environm ental Science and Technology. 2011;45(20):9017-23.

71. Gardiner WW, Word JQ, Word JD, Perkins RA, McFarlin KM, Hester BW, et al. The acute toxicity of chem ically and physically dispersed crude oil to key arctic species under arctic conditions during the open water season. Environm ental Toxicology and Chem istry. 2013;32(10):2284300.

72. Cam us L, Brooks S, Geraudie P, Hjorth M, Nahrgang J, Olsen GH, et al. Com parison of produced water toxicity to Arctic and tem perate species. Ecotoxicology and Environm ental Safety. 2015;113:24858.

73. Chapm an PM. Toxicity delayed in cold freshwaters? Journal of Great Lakes Research. 2016;42(2):286-

74. Martínez-Góm ez C, Vethaak AD, Hylland K, Burgeot T, Köhler A, Lyons BP, et al. A guide to toxicity assessm ent and $\mathrm{m}$ onitoring effects at lower levels of biological organization following $\mathrm{m}$ arine id spills in European waters. ICES Journal of Marine Science: Journal du Conseil. 2010 Septem ber 1, 2010,67(6):1105-18.

75. Di Toro DM, Zarba CS, Hansen DJ, Berry WJ, Swartz RC, Cowan CE, et al. Technical basis for establishing sedim ent quality criteria for nonionic organic chem icals using equilibrium partitioning. Environm ental Toxicology and Chem istry. 1991;10(12):154183.

76. Morrison HA, Gobas FAPC, Lazar R, Haffner GD. Developm ent and verification of a bioaccum ulation m odel for organic contam inantsin benthic invertebrates. Environm ental Science \& Technology. 1996;30(11):3377-84

77. Kaag NHBM, Foekem a EM, Scholten MCT, van Straalen NM.Com parison of contam inant accum ulation in three species of $\mathrm{m}$ arine invertebrates with different feeding habits. Envionm ental Toxicology and Chem istry. 1997;16(5):837-42.

78. Poot A, Jonker MTO, Gillissen F, Koelm ans AA. Explaining PAH desorption from sedim ents using Rock Eval analysis. Environm ental Pollution. 2014;193:247-53.

79. Koelm ans AA, Jonker MTO, CornelissenG, Bucheli TD, Van Noort PCM, Gustafsson Ö. Black carbon: The reverse of its dark side. Chem osphere. 2006;63(3):365-77.

80. Selck H, Drouillard K, Eisenreich K, Koelm ans AA, Palm qvist A, Ruus A, et al. Explaining differences between bioaccum ulation $\mathrm{m}$ easnem ents in laboratory and field data through use of a probabilistic m odeling approach. Integrared Environm entalAssessm ent andManagem ent 2012;8(1):42-63.

81. Burkhard LP, Cook PM, Lukasewycz MT. Com parison of biota-sedim ent accum ulation factors across ecosystem s. Environm ental Science \& Technology. 2005;39(15):571थ1.

82. Weisbrod AV, Woodburn KB, Koelm ans AA, Parkerton TF, McElroy AE, Borgå K. Evaluation of bioaccum ulation using in vivo laboratory and field sudies. Integrated Environm ental Assessm entand Managem ent. 2009;5(4):598-623.

83. Sidney LA, Diepens NJ, Guo X, Koelm ans AA. Traitbased m odelling of bioaccum ulation by freshwater benthic invertebrates. Aquatic Toxicology. 2016;176:88-96.

84. Kuzyk ZZA. Bioaccum ulation of PCBs from contam inatededim ents in a coastal $\mathrm{m}$ arine ecosystem of Northern Labrador. Kingston, Ontario (Canada): Queen's University. 2000.

85. Warner NA, Evenset A, Christensen G, Gabrielsen GW, Borgå K, Leknes H. Volatile siloxanes in the European Arctic: Assessm ent of sourcesand spatial distribution. Environm ental Science \& Technology. 2010;44(19):7705-10.

86. Hagger JA, Jones MB, Leonard DRP, Owen R, Galloway TS. Biom arkers and integrated environm ental risk assessm ent: Are there $m$ ore questions than answers? Integated Environm entalAssessm entand Managem ent 2006;2(4):312-29. 


\section{List of references}

87. Regoli F, Giuliani ME. Oxidative pathways of chem ical toxicity and oxidative stress biom arkers in m arine organism s. Marine Environm ental Research. 2014;93:1067.

88. Regoli F, Winston GW, Gorbi S, Frenzilli G, Nigro M, Corsi I, et al. Integrating enzym atic responses to organic chem ical exposure with total oxyradical absorbing capacity and DNA dam age in the european eel Anguilla anguilla. Environm ental Toxicology and Chem istry. 2003;22(9):21209.

89. Nahrgang J, Cam us L, Carls MG, Gonzalez P, Jönsson M, Taban IC, et al. Biom arker responses in polar cod (Boreogadus saida) exposed to the water soluble fraction of crude oil. Aquatic Toxicology. 2010;97(3):23442.

90. Thain JE, Vethaak AD, Hylland K. Contam inants in $\mathrm{m}$ arine ecosystem s: developing an integrated indicator fram ework using biologicaleffect techniques. ICES Journal of Marine Science: Journal du Conseil. 2008 Novem ber 1, 2008;65(8):150814.

91. Davies IM, Vethaak AD. Integrated $\mathrm{m}$ arine environm ental $\mathrm{m}$ onitoring of chem icals and their effects. ICES Cooperative Research Report. Copenhagen (Denm ark): International Councilfor the Exploration of the Sea. 2012; Report No. 315.

92. Abele D, Puntarulo S. Form ation of reactive species and induction ofantioxidant defence system $\mathrm{s}$ in polar and tem perate $\mathrm{m}$ arine invertebrates and fish. Com parative Biochem istry and Physiology Part A: Molecular \& Integrative Physiology. 2004;138(4):405-15.

93. Livingstone DR. Contam inantstim ulated reactive oxygen species production and oxidative dam age in aquatic organism s. Marine Pollution Bulletin. 2001;42(8):656-66.

94. Hylland K. Polycyclic arom atic hydrocarbon (PAH) ecotoxicology in m arine eosystem s. Journal of Toxicology and Environm ental Health, Part A. 2006;69(1-2):109-23.

95. Ham pel M, Blasco J, Martín Dáz ML. Biom arkers and Effects. Marine Ecotoxicology: Current Knowledge and Future Issues: Elsevier. 2016; p. 45.

96. Araújo CVM, Moreira-Santos M, Ribeiro R. Active and passive spatial avoidance by aquatic organism s from environm ental stressors: A com plem entary perspective and a critical review. Environemt International. 2016;92-93:405-15.

97. Basu N. Applications and im plications of neurochem ical biom arkers in environm ental toxicology. Environm ental Toxicologyand Chem istry. 2015;34(1):22-9.

98. Kravitz MJ, Lam berson JO, Ferraro SP, Swartz RC, Boese BL, Specht DT. Avoidance response of the estuarine am phipod Eohaustorius estuarius to polycyclic arom atic hydrocarboncontam inated, fieldcollected sedim ents. Environm ental Toxicology and Chem istry. 1999;18(6):12325.

99. Hellou J, Cheesem an K, Jouvenelle MLL, Robertson S. Behavioral response of Corophium volutator relative to experim ental conditions, physical and chem ical disturbances. Environm ental Toxicology and Chem istry. 2005;24(12):3061-8.

100. De Lange HJ, Sperber V, Peeters ETHM. Avoidance of polycyclic arom atic hydrocarbon-contam inated sedim ents by the freshwater invertebrates Gam m arus pulex and Asellus aquaticus. Environm ental Toxicology and Chem istry. 2006;25(2):452-7.

101. Ward DJ, Sim pson SL, Jolley DF. Avoidance of contam inated sedim ents by an am phipod (Melita plum ulosa), a harpacticoid copepod (Nitocra spinipes), and a snail (Phallom edusa solida). Environm ental Toxicology and Chem istry. 2013;32(3):644-52.

102. Hatlen K, Cam us L, Berge J, Olsen GH, Baussant T. Biological effects of water soluble fraction of crude oil on the Arctic sea ice am phipod Gam m arus wilkitzkii. Chem istry and Ecology. 2009;25(3):1562. 
103. Sharm a P, Schiewer S. Assessm ent ofcrude oil biodegradation in arctic seashore sedim ents: effects of tem perature, salinity, and crude oil concentration. Environm ental Science and Pollution Research.

2016;23(15):14881-8.

104. Olsen GH, Carroll ML, Renaud PE, Am brose WG, Olssøn R, Carroll J.Benthic com m unity response to petroleum-associated com ponents in Arctic versus tem perate $m$ arine sedim ents. Marine Biology. 2007;151(6):2167-76.

105. Brown KE, King CK, Harrison PL. Lethal and behavioral im pacts of diesel and fuel oil on the Antarctic am phipod Param oera walkeri. Environm ental Toxicbogy and Chem istry. 2017.

106. Security NMoJaP. Svalbard: Report No. 22 (2008-2009) to the Storting. Oslo (Norway): Ministry of Justice and Public Security. 2009.

107. Woolfenden ENM, Hince G, Powell SM, Stark SC, Snape I, Stark JS, et al. The rate of rem oval and the com positional changes of diesel in Antarcic m arine sedim ent. Science of the Total Environm ent. 2011;410 411:205-16.

108. Gesteira JLG, Dauvin JC. Am phipods are good bioindicators of the im pact of il spills on soft-bottom $\mathrm{m}$ acrobenthic $œ \mathrm{~m} \mathrm{~m}$ unities. Marine Pollution Bulletin. 2000;40(11):101727.

109. Washburn T, Rhodes ACE, Montagna PA. Benthic taxa as potential indicators of a deep-sea oil spill. Ecological Indicators. 2016;71:587-97.

110. Lane A, Riddle MJ. Toxicity of dispersed and undispersed diesel in sedim ents to the Antarctic ophiuroid Ophiura crassa. Australasian Journal of Ecotoxicology. 2004;10(2):115-21.

111. Vázquez M. Bioaccum ulation and effects of parent and alkylated PAHs in an Arcic m arine am phipod (Gam m arus setosus) originating from pristine and historically contam inated sites in Svalbard: im plications for sensitivity and adaptation. Trom sø (Norway): University of Trom sø2016.

112. Thorson G. The larval developm ent, growth andm etabolism of arctic $m$ arine bottom invertebrates com pared with those of other seas. Copenhague: C.A. Reitzel 1936.

113. Sirenko BI, Gagaev SY. Unusual abundance of $\mathrm{m}$ acrobenthos and biological invasions in the Chukchi Sea. Russian Journal of Marine Biology. 2007;33(6):355-64.

114. Blanchard AL, Parris CL, Knowlton AL, Wade NR. Benthic ecology of the northeastern Chukchi Sea. Part I. Environm ental characteristics and $\mathrm{m}$ acrofaunal com $\mathrm{m}$ unity structure, 2008010. Continental Shelf Research. 2013;67:52-66.

115. Grebm eier JM, Bluhm BA, Cooper LW, Danielson SL, Arrigo KR, Blanchard AL, et al. Ecosystem characteristics and processes facilitating persistent $\mathrm{m}$ acrobenthic biom ass hotspots and associated benthivory in the Pacific Arctic. Progress in Oceanography. 2015;136:92-114.

116. C. Em m erson GL. Arctic opening: opportunity and isk in the High North. London (United Kingdom ): Chatham House. 2012

117. Miller GH, Lehm an SJ, Refsnider KA, Southon JR, Zhong YCGL. Unprecedented recent sum m er warm th in Arctic Canada.Geophysical Research Letters. 2013;40(21):5745-51.

118. Boitsov S, Jensen HKB, Klungsøyr J. Natural background and anthropogenic inputs of polycyclic arom atic hydiocarbons (PAH) in sedim ents of southwestern Barents Sea. Marine Environm ental Research. 2009;68(5):236-45.

119. Dahle S, Savinov VM, Matishov GG, Evenset A, Næs K. Polycyclic arom atic hydrocarbons (PAHs) in bottom sedim ents of the Kara Sea shelf, Gulf of $\mathrm{Ob}$ and Yenisei Bay. Scince of the Total Environm ent 2003;306(1-3):57-71. 


\section{List of references}

120. Yunker MB, Macdonald RW, Vingarzan R, Mitchell RH, Goyette D, Sylvestre S. PAHs in the Fraser River basin: a critical appraisal of PAH ratios as indicators of PAH source and com position. Organic Geochem istry. 2002;33(4):489-515.

121. De Laender F, Ham m er J, Hendrks AJ, Soetaert K, Janssen CR. Com biningm onitoring data and m odeling identifies PAHs as em erging ontam inants in the Arctic. Environm ental Science \& Technology. 2011;45(20):9024-9.

122. Cam us L, Birkely SR, Jones MB, Børseth JF, Grøsvik BE, Gulliksen B, et al. Biom arker responses and PAH uptake in Mya truncata following exposure to oil-contam inated sedim ent in an Arctio fjord (Svalbard). Science of the Total Environm ent. 2003;308(1-3):221-34.

123. Hung H, Kallenborn R, Breivik K, Su Y, Brorström-Lundén E, Olafsdottir K, et al. Atm ospheric $\mathrm{m}$ onitoring of organic pollutants in the Arctic under the Arctic Monitoring and Assessm ent Program $\mathrm{me}$ (AMAP): 1993-2006. Science of the Total Environm ent. 2010;408(15):285473.

124. Ma J, Hung H, Tian C, Kallenborn R. Revolatilization of persistent organic pollutants in the Arctic induced by clim ate change. Nature Clim ate Change.2011;1(5):255-60.

125. Chapm an PM, Riddle MJ. Toxic effects of contam inants in polar m arine evironm ents. Environm ental Science \& Technology. 2005;39(9):200A-6A.

126. Hallanger IG, Ruus A, Herzke D, Warner NA, Evenset A, Heim stad ES, et al. Influence of season, location, and feeding strategy on bioaccum ulation of halogenated organic contam inants in Arctic m arine zooplankton. Environm entalToxicology and Chemistry. 2011;30(1):77-87.

127. Renaud P, Morata N, Carroll ML, Denisenko SG, Reigstad M. Pelagic-benthic coupling in the western Barents Sea: Processes and tim e scales.Deep-Sea Research Part II: Topical Studies in Oceanography. 2008;55(20-21):2372-80.

128. van den Brink NW, Riddle MJ, van den Heuvel-Greve M, van Franeker JA. Contrasting tim e trends of organic contam inants in Antarctic pelagic and benthic food webs. Marine Pollution Bulletin. 2011;62(1):128-32.

129. Dahle S, Savinov, V., Petrova, V., Klungsøyr, J., Savinova, T., Batova, G. \& Kursheva, A. Polycyclic arom atic hydrocarbons (PAHs) in Norwegian and Russian Arctic m arine sedim ents: concentrations, geographical distribution and sources. Norwegian Journal of Geology. 2006;86(1):41-50.

130. Kędra M, Włodarska-Kowalczuk M, Wesławski JM. Decadal change in m acrobenthic softbottom com m unity structure in a high Arctic fjord (Kongsfjorden, Svalbard). Polar Biobgy. 2010;33(1):1-11.

131. Hop H, Pearson T, Hegseth EN, Kovacs KM, Wiencke C, Kwasniewski S, et al. The m arine ecosystem of Kongsfjorden, Svalbard. Polar Research. 2002;21(1):167-208.

132. Olsen GH, Sm it MGD, Carroll J, Jæger I, Sm ith T, Cam us L. Arctic versus tem perate com parison of risk assessm ent $\mathrm{m}$ etrics for Zm ethylnaphthalene. Marine Environm ental Research. 2011;72(4):179-87.

133. Markert B, Wappelhorst O, Weckert V, Herpin U, Siewers U, Friese K, et al. The use of bioindicators for $m$ onitoring the heavy-m etal status of the environm ent. Journal of Radioanalytical and Nuclear Chen istry. 1999;240(2):425-9.

134. Renaud PE, Tessm ann M, Evenset A, Christensen GN. Benthic food-web structure of an Arctic fjord (Kongsfjorden, Svalbard). Marine Biology Research. 2011;7(1):13-26.

135. Nygård H, Berge J, Søreide JE, Vihtakari M, Falk-Petersen S. The am phipod scavenging guild in two Arctic fjords: seasonal variations, abundance and trophic interactions. Aquatic Biology. 2012;14(3):247-64.

136. Kędra M, Kuliński K, Walkusz W, Legeżyńska J. The shallow benthic food web structure in the high Arctic does not follow seasonal changes in the surrounding environm ent. Estuarine, Coastal and Shelf Science. 2012;114:183-91. 
137. Richm an SE, Lovvorn $\mathbb{R}$. Effects of clam species dom inance on nutrient and energy acquisition by spectacled eiders in the Bering Sea. Marine Ecology Progress Series. 2003 October 17, 2003;261:283-97.

138. Dunton KH. Chukchi Sea Offshore Monitoring in Drilling Area (COMIDA): Chem ical and Benthos (CAB). Anchorage, AK: University of Texas Marine Science Institute. 2012; OCS Study BOEM 2012-012.

139. Rust AJ, Burgess RM, Brownawell BJ, McElroy AE. Relationship between m etabolism and bioaccum ulation of benzo[a]pyrene in benthic invertebrates. Environm ental Toxicology and Chem istry. 2004;23(11):2587-93.

140. Tessm ann M. Trophic transfer of persistent organic pollutants in the benthic food web of Kongsfjorden, Spitzbergen. Christian-Albrechts-Universität zu Kiel. 2008.

141. Evenset A, Hallanger IG, Tessm ann M, Warner N, Ruus A, Borgå K, et al. Seasonal variation in accum ulation of persistent organic pollutants in an Arctic $\mathrm{m}$ aris benthic food web. Science of the Total Environm ent. 2016;542, Part A:10820.

142. Chapm an PM, Riddle MJ.Missing and needed: polar m arine ecotoxicology. Marine Pollution Bulletin. $2003 ; 46(8): 927-8$.

143. Lake JL, Rubinstein NI, Lee H, Lake CA, Heltshe J, Pavignano S. Equilibrium partitioning and bioaccum ulation of sedim entassociated contam inants by infaunalorganism s. Environm ental Toxicology and Chem istry. 1990;9(8):1095-106.

144. Word JQ, Gardiner W, Melbye A, Merlin F, Brakstad O, Cam us L, et al. Environm ental effects of spilled oil and response technologies in the Arctic: Literature review and recom $\mathrm{m}$ endaions. International Association of Oil and Gas Producers (OGP). Arctic Oil Spill Response Technology - Joint Industry Program m e (JIP). 2014.

145. Svendsen H, Beszczynska-Møller A, Hagen JO, Lefauconnier B, Tverberg V, Gerland S, et al. The physical environm ent of KongsfjordenKrossfjorden, and Arctic fjord system in Svalbard. Polar Research. 2002;21(1):133-66.

146. Kuliński K, Kędra M, Legeżyńska J, Gluchowska M, Zaborska A. Particulate organic m atter sinks and sources in high Arctic fjord. Journal of Marine System s. 2014;139:27-37.

147. Włodarska-Kowalczuk M, Pearson TH. Soft-bottom m acrobenthic faunal associaions and factors affecting species distributions in an Arctic glacial fjord (Kongsfjord, Spitsbergen). Polar Biology. 2004;27(3):155-67.

148. Sander G. Lim its of acceptable change caused by local activities in Ny-Ålesund: Report from a Pre project, Containing a Proposal for a Main Project. Norwegian Polar Institute. 2014.

149. van den Heuvel-Greve MJ, Szczybelski AS, van den Brink NW, Kotterm an MJJ, Kwadijk CJAF, Evenset A, et al. Low organotin contam ination of harbour sedim ent in Svalbard. Polar Biology 2016;39(10):1699-709.

150. Kupryianchyk D, Reichm an EP, Rakowska MI, Peeters ETHM, Grotenhuis JTC,Koelm ans AA. Ecotoxicological effects of activated carbon am endm ents on $\mathrm{m}$ acroinvertebrates in nonpolluted and polluted sedim ents. Environm ental Science \&Technology. 2011;45(19):8567-74.

151. Tobiszewski M, Nam ieśnik J. PAH diagnostic ratios for the identification of pollution em ission sources. Environm ental Pollution. 2012;162:110-9.

152. Arp HP, Ruus A, Macken A, Lillicrap A. Quality assurance of environm ental quality standards. Odo (Norway): NIVA and NGI. 2014; Contract No.: M-241.

153. Webster L, Fryer R, Davies I, Roose P, Moffat C. Background Docum ent on CEMP assessm ent criteria for the QSR 2010. London (United Kingdom ): OSPAR Com m ission2009; 461/2009 Contract No.: 978-1907390-08-1. 


\section{List of references}

154. Hansen DJ, DiToro DM, McGrath JA, Swartz RC, Mount DR, Burgess RM, et al. Procedures for the derivation of equilibrium partitioning sedim ent benchm arks (ESBs) for the protection of benthic organism s: PAH mixtures. Washington, DC.: United States Environm ental Protection Agency. 2003; 600R02013.

155. Directive 2013/39/EU of the European Parliam ent and of the Council of 12 August 2013 am ending Directives 2000/60/EC and 2008/105/EC as regards priority substances in the field of water policy Text with EEA relevance. 2013

156. Di Toro DM, McGrath JA, Hansen DJ. Technical basis for narcotic chem icals and polycyclic arom atic hydrocarbon criteria. I. Water and tissue. Environm ental Toxicology and Chem istry. 2000;19(8):195170.

157. Auen JE. Kings Bay-ulykken og borgerlig sam arbeid.2016 [cited 201631 July]; Available from : http://ndla.no/nb/node/161573.

158. U.S.E.P.A. Mid-Atlantic Integrated Assessm ent (MAIA) 1997-98 Sum m ary Report. 2002,Contract No.: EPA/620/R-02/003.

159. Evenset A. Norwegian and Russian monitoring of PCB contam ination at settlem ents in Svalbard: Com parison of field and analysis m ethods and esults. Trom sø (Norway): Akvaplan-niva AS. 2009.

160. Evenset A. Pollution in settlem ents in Svalbard. The need for follow-up surveys and measures. Trom sø (Norway): Akvaplan-niva AS. 2010.

161. Holte B, Dahle S, Gulliksen B, Næs K. Som e m acrofaunal effects of local pollution and glacierinduced sedim entation, with indicative chem ical analyses, inthe sedim ents of two Arctic fjords.Polar Biology. 1996;16(8):549-57.

162. Zhang P, Ge L, Gao H, Yao T, Fang X, Zhou C, et al. Distribution and transfer pattern of polychlorinated biphenyls (PCBs) am ong the selected environm ental m edia of N-Æ̊lesund, the Arctic: As a case study. Marine Pollution Bulletin. 2014;89(1-2):267-75.

163. Evenset A, Christensen GN, Palerud R. Miljøgifter i m arine sedim enter, Isfjorden, Svalbard 2005. Trom sø (Norway): Akvaplanniva AS, 2006; Contract No.: APN-414.3341.

164. Jörundsdóttir HÓ, Jensen S, Hylland K, Holth TF, Gunnlaugsdóttir H, Svavarsson J, et al. Pristine Arctic: Background m apping of PAHs, PAH m etabolites and inorganic trace elem ents in the NorthAtlantic Arctic and sub-Arctic coastal environm ent. Science of he Total Environm ent. 2014;493:719-28.

165. Hwang H-M, Wade TL, Sericano JL. Residue-response relationship between PAH body burdens and lysosom al $\mathrm{m}$ em brane destabilization in eastern oysters (Crassostrea virginica) and toxicokinetics of PAHs. Journal of Environm ental Science and Health, Part A. 2008;43(12):1373-80.

166. Gusev AA, Rudinskaya LV. Shell form, growth, and production of Astarte borealis (Schum acher, 1817) (Astartidae, Bivalvia) in the southeastern Baltic Sea. Oceanology. 2014;54(4):458-64.

167. Sokołowski A, Wolowicz M, Hum m el H. Free am ino acids in the clam Macom a balthica L. (Bivalvia, Mollusca) from brackish waters of the southern Baltic Sea. Com parative Biochem istry and Physiology Part A: Molecular \& Integrative Physiology. 2003;134(3):579-92.

168. Liu D, Pan L, Li Z, Cai Y, Miao J. Metabolites analysis, m etabolic enzym e activities and bioaccum ulation in the clam Ruditapes philippinarum exposed to benzo[a]pyrene. Ecotoxicology and Environm ental Safety. 2014;107:251-9.

169. Livingstone DR. Organic Xenobiotic Metabolism in Marine Invertebrates. Advances in Com parative and Environm ental Physiology. Berlin, Heidelberg: Springer Berlin Heidelberg 1991; p. 45-185.

170. Widdows J, Bayne BL, Donkin P, Livingstone DR, Lowe DM, Moore MN, et al. Measurement of the responses of $\mathrm{m}$ ussels to environm ental stress and pollution in Sullom Voe: a basdine study. Proceedings of the Royal Society of Edinburgh Section B: Biological Sciences. 1981;80:323-38. 
171. Singh N, Singh V. Spheroidal carbonaceous particles (SCPs): Indicator of anthropogenic pollutants in Kongsfjorden, Ny-Ålesund, Arctic. ARCTIC FRONTIERS; Trom sø (Norway) 2016.

172. Hop H, Sagerup K, Schlabach M, Gabrielsen GW. Persistent organic pollutants in $m$ arine $m$ acre benthos near urban settlem ents inSvalbard; Longyearbyen, Pyram iden, Barentsburg and Ny Ålesund. Trom sø (Norway): Norwegian Polar Institute. 2001.

173. Renaud PE, Løkken TS, Jørgensen LL, Berge J, Johnson BJ. Macroalgal detritus and food-web subsidies along an Arctic fjord depth-gradient. Frontiers in Marine Science. 2015;2.

174. Mayzaud P, Boutoute M, Noyon M, Narcy F, Gasparini S. Lipid and fatty acids in naturally occurring particulate $\mathrm{m}$ atter during spring and sum $\mathrm{m}$ er in a high arctic fjord (Kongsfjorden, Svalbard). Mane Biology. 2012;160(2):383-98.

175. Koelm ans AA, Gillissen F, Makatita W, Van Den Berg M. Organic carbon norm alisation of PCB, PAH and pesticide concentrations in suspended solids. Water Research. 1997;31(3):461-70.

176. Koelm ans AA, Lijklem a L, Jim énez CS. Sorption o£hlorobenzenes to m ineralizing phytoplankton. Environm ental Toxicology and Chem istry. 1993;12(8):142539.

177. Galbán-Malagón C, Berrojalbiz N, Ojeda M-J, Dachs J. The oceanic biological pum p m odulates the atm ospheric transport of persistent organic pollutants to the Arctic. 2012;3:862.

178. Kelton WM, William GA, Jr., Beverly JJ, MingYi S, Glenn RL, Lisa MC, et al. Benthic com m unity response to ice algae and phytoplankton in Ny-Ålesund, Svalbard. Marine Ecology Progress Series. 2006;310:1 14.

179. Rust AJ, Burgess RM, McElroy AE, Cantwell MG, Brownawell BJ. Influence of soot carbon on the bioaccum ulation of sedim entbound polycyclic arom atic hydrocarbons by $m$ arine benthic invertebrates: An interspecies com parison. Environm ental Toxicology and Chem istry2004;23(11):2594-603.

180. McElroy AE, Barron MG, Beckvar N, Kane Driscoll SB, Meador JP, Parkerton TF, et al. A review of the tissue residue approach for organic and organom etallic com pounds in aquatic organism $\mathrm{s}$. Integrated Environm ental Assessm ent andManagem ent. 2011;7(1):5074.

181. Jørgensen A, Giessing AMB, Rasm ussen LJ, Andersen O. Biotransform ation of polycyclic arom atic hydrocarbons in m arine polychaetes. Marine Environm ental Research. 2008;65(2):17186.

182. Zheng S, Chen B, Qiu X, Lin K, Yu X. Three novel cytochrom e P450 genes identified in the $\mathrm{m}$ arine polychaete Perinereis nuntia and their transcriptional response to xenobiotics. Aquatic Toxicology. 2013;134$135: 11-22$.

183. Jørgensen A, Giessing AMB, Rasm ussen LJ, Andersen O. Biotransform aton of the polycyclic arom atic hydrocarbon pyrene in the $\mathrm{m}$ arine polychaete Nereis virens. Environm ental Toxicology and Chem istry. 2005;24(11):2796-805.

184. Lüchm ann KH, Dafre AL, Trevisan R, Craft JA, Meng X, Mattos JJ, et al. A light in the darkness: New biotransform ation genes, antioxidant param eters and tissuespecific responses in oysters exposed to phenanthrene. Aquatic Toxicology. 2014;152:324-34.

185. Granberg ME, Selck H. Effects of sedim ent organic $m$ atter quality on bioaccum ulation, degradation, and distribution of pyrene in two $\mathrm{m}$ acrofaunal species and their surrounding sedim ent. Marine Environm ental Research. 2007;64(3):313-35.

186. North CA, Lovvorn JR, Kolts JM, Brooks ML, Cooper LW, Grebm eier JM. Depositfeeder diets in the Bering Sea: potential effects of clim atic loss of sea icerelated $\mathrm{m}$ icroalgal bloom s. Ecological Applications. 2014;24(6):1525-42.

187. Legeżyńska J, Kędra M, Walkusz W. Identifying trophic relationships within the high Arctic benthic com m unity: how m uch can fatty acids teP Marine Biology. 2014;161(4):821-36. 


\section{List of references}

188. Neff JM, Durell GS, Trefry JH, Brown JS. Environm ental sudies in the Chukchi Sea 2008: Chem ical characterization. Duxbury, MA: Battelle Mem orial Institute. Exponent, Inc. Florida Institute of Technology. Neff \& Associates. 2010; Service Contract No. 68393.0-SA-AKR.

189. Molvær J, Knutzen J, Magnusson J, Rygg B, Skei J, Sørensen J. Classification of environm ental quality in fjords and coastal waters. A guide. Statens forurensningstilsyn. 1997; TA-1467/1997 Contract No.: 82-7655$367-2$.

190. Weisbrod AV, Sahi J, Segner H, Jam es MO, Nichols J, Schultz I, et al. The state of in vitro science for use in bioaccum ulation assessm ents for fish. Environm ental Toxicology and Chem istry. 2009;28(1):8ø6.

191. Menone ML, Miglioranza KSB, Iribarne O, Aizpún de Moreno JE, Moreno VcJ. The role of burrowing beds and burrows of the SW Atlantic intertidal crab Chasm agnathus granulata in trapping organochlorine pesticides. Marine Pollution Bulletin. 2004;48(3-4):240-7.

192. Jantunen APK, Tuikka A, Akkanen J, Kukkonen JVK. Bioaccum ulation of atrazine and chlorpyrifos to Lum briculus variegatus from lake sedim ents. Ecotoxicology and Environm ental Safety. 2008;71(3):868.

193. Besseling E, Wegner A, Foekem a EM, van den HeuvelGreve MJ, Koelm ans AA. Effects of $\mathrm{m}$ icroplastic on fitness and PCB bioaccum ulation by the ugworm Arenicola $\mathrm{m}$ arina (L.). Environm ental Science \& Technology. 2013;47(1):593-600.

194. Han YM, Bandowe BAM, Wei C, Cao JJ, Wilcke W, Wang GH, et al. Stronger association of polycyclic arom atic hydrocarbons with soot than with char in soils and sedim ents. Chem osphere. 2015;119:1335-45.

195. Nizzetto PB, Aas, W., Krogseth, I.S. Monitoring of environm ental contam inants in air and precipitation, annual report 2013 Kjeller (Norway): NILU - Norwegian Institute for Air Research. 2014; Report No.: M202/2014 Contract No.: 978-82-425-2690-8.

196. Moerm ond CTA, Zwolsm an JJG,Koelm ans AA.Black Carbon and ecological factors affect in situ biota to sedim ent accum ulation factors for lydrophobic organic com pounds in flood plain bkes. Environm ental Science \& Technology. 2005;39(9):3101-9.

197. Ruus A, Bøyum O, Grung M, NæsK. Bioavailability of PAHs in alum inum sm elter affected sedim ents: Evaluation through assessm ent of pore water concentrations and in vivo bioaccum ulation. Environm ental Science \& Technology. 2010;44(24):9291-7.

198. Ma Y, Halsall CJ, Crosse JD, Graf C, Cai M, He J, et al. Persistent organic pollutants in ocean sedim ents from the North Pacific to the Arctic Ocean. Jonnal of Geophysical Research C: Oceans. 2015;120(4):2723-35.

199. PAME. Arctic Offshore Oil and Gas Guidelines. Arctic Council. 2009.

200. OSPAR. Background Docum ent concerning Techniques for the Managem ent of Produced Water from Offshore Installations. London (United Kingdom ): OSPAR Com m ission2002.

201. Montagna PA, Baguley JG, Cooksey C, Hartwell I, Hyde LJ, Hyland JL, et al. Deep-sea benthic footprint of the Deepwater Horizon Blowout. PLOS ONE. 2013;8(8):e70540.

202. DeBlois EM, Kiceniuk JW, Paine MD, Kilgour BW, Tracy E, Crowley RD, et al. Exam ination of body burden and taint for Iceland scallop (Chlam ys islandica) and Am erican plaice (Hippoglossoides platessoides) near the Terra Nova offshore oil developm ent over ten years of drilling on the GrandBanks of Newfoundland, Canada. Deep Sea Research Part II: Topical Studies in Oceanography. 2014;110:65-83.

203. ECETOC. High inform ation content technologies in support of read-across in chem ical risk assessm ent. Brussels: European Centre for Ecotoxicology and Toxicology of Chem icals 2010; Report No.: 109.

204. Boese BL, Lee Ii H, Specht DT, Randall R, Pelletier J. Evaluation of PCB and hexachlorobenzene biota-sedim ent accum ulation factors based on ingested sedim ent in a deposifeeding clam . Environm enal Toxicology and Chem istry. 1996;15(9):15849. 
205. Thom ann RV, Kom los J. Model of biotasedim ent accum ulation factor for polycyclic arom atic hydrocarbons. Environm ental Toxicology and Chem istry. 1999;18(5):10608.

206. Pouch A, Zaborska A, Pazdro K. Concentrations and origin of polychlorinated biphenyls (PCBs) and polycyclic arom atic hydrocarbons (PAHs) in sedim ents of western Spitsbergen fjords (Kongsfjorden, Hornsund, and Adventfjorden). Environm ental Monitoring and Assessm ent. 2017;189(4):175.

207. Bogen J, Bønsnes TE. Erosion and sedim ent transport in High Arctic rivers, Svalbard.Polar Research. 2003;22(2):175-89.

208. Steur C, Seys J, Eppinga J. Ecologisch profiel van het Nonnetje (Macom a balthica). 1996.

209. Weem s J, Iken K, Gradinger R, Wooler MJ. Carbon and nitrogen assim ilation in the Bering Sea clam s Nuculana radiata and Macom a m oesta. Journal of Experim ental Marine Biology and Ecology. 2012;430431:3242.

210. Neff JM, Hillm an RE, Scott Carr R, Buhl RL,Lahey JI. Histopathologic and biochem ical responses in Arctic $m$ arine bivalve $m$ olluscs exposed to experim entally spilled id. Arctic. 1987;40(Suppl 1):220-9.

211. Sun M-Y, Clough LM, Carroll ML, Dai J, Am brose Jr WG, Lopez GR. Different responses of two com $\mathrm{m}$ on Arctic $\mathrm{m}$ acrobenthic species(Iacom a balthica and Monoporeia affinis) to phytoplankton and ice algae: Will clim ate change im pacts be species specific? Journal of Experim ental Marine Biology and Ecology. 2009;376(2):110-21.

212. Jensen LK, Honkanen JO, Jæger I, Carroll J. Bioaccum ulation of phenanthrene and benzo[a]pyrene in Calanus finm archicus. Ecotoxicology and Environm ental Safety. 2012;78:22531.

213. Carrasco-Navarro V, Jæger I, Honkanen JO, Kukkonen JVK, Carroll J, Cam us L. Bioconcentration, biotransform ation and elim ination ofyrene in the arctic crustacean Gam m arus setosus (Am phipoda) at two tem peratures. Marine Environm ental Research. 2015;110:1019.

214. Tschischka K, Abele D, Portner HO. Mitochondrial oxyconform ity and cold adaptation in the polychaete Nereis pelagica and the bivalve Arctica islandica from the Baltic and White Seas. Journal of Experim ental Biology. 2000;203(21):3355.

215. Nahrgang J, Brooks SJ, Evenset A, Cam us L, Jonsson M, Sm ith TJ, et al. Seasonal variation in biom arkers in blue $\mathrm{m}$ ussel (Mytilus edulis),Icelandic scallop (Chlam ys islandica) and Atlantic cod (Gadus $\mathrm{m}$ orhua)-Im plications for environm ental $\mathrm{m}$ onitoring in the Barents Sea. Aquatic Toxicology. 2013;127:2-B5.

216. Cornelissen G, Gustafsson Ö, Bucheli TD, Jonker MTO, Koelm ans AA, Van Noort PCM. Extensive sorption of organic com pounds to black carbon, coal, and kerogen in sedim ents and soils: Mechanism s and consequences for distribution, bioaccum ulation, and biodegradation. Environm ental Science \& Technology. 2005;39(18):6881-95.

217. Keuken MP, Moerm an M, Zandveld P, Henzing JS. Total and size-resolved particle num ber and black carbon concentrations near an industrial area. Atm ospheric Environm ent. 2015;122:196205.

218. Cornelissen G, Breedveld GD, Næs K, Oen AMP, Ruus A. Bioaccum ulation of native polycyclic arom atic hydrocarbons from sedim ent by a polychaete and a gastropod: Frele dissolved concentrations and activated carbon am endm ent. Environm ental Toxicology and Chem istry. 2006;25(9):23495.

219. Beukem a JJ, Cadée GC, Dekker R, Philippart CJM. Annual and spatial variability in gains of body weight in Macom a balthica (L.): Rdationships with food supply and water tem perature. Journal of Experim ental Marine Biology and Ecology. 2014;457:105-12.

220. McLeod PB, van den Heuvel-Greve MJ, Allen-King RM, Luom a SN, Luthy RG. Effects of particulate carbonaceous $\mathrm{m}$ atter on the bioavailability of benzo[a]pyrene and 2,2',5,5'-tetrachlorobiphenyl to the clam, Macom a balthica. Environm ental Science \& Technology. 2004;38(17):45496. 


\section{List of references}

221. Ruus A, Allan IJ, Øxnevad S, Schaanning MT, Borgå K, Bakke T, et al. In vivo bioaccum ulation of contam nants from historically polluted sedim ents - Relation to bioavailability estim ates. Science of he Total Environm ent. 2013;442:336-43.

222. Yates K, Pollard P, Davies IM, Webster L, Moffat CF. Application of silicone rubber passive sam plers to investigate the bioaccum ulation of PAHs by Nereis virens from $\mathrm{m}$ arine sedim entEnvironm ental Pollution. 2011;159(12):3351-6.

223. Trem blay L, Kohl SD, Rice JA, Gagné JP. Effects of tem perature, salinity, and dissolved hum ic substances on the sorption of polycyclic arom atic hydrocarbons to estuarine particles. Marine Chem istry. 2005;96(1-2):21-34.

224. Koelm ans AA, Jim énez CS. Tem perature dependency of chlorobenzene bioaccum ulation in phytoplankton. Chem osphere. 1994;28(12):2041-8.

225. Hanelt D, Tüg H, Bischof K, Groß C, Lippert H, Sawall T, et al. Light regim e in an Arctic fjord: a study related to stratospheric ozone depletion as a basis for determ ination of UV effects on algal growth. Marine Biology. 2001;138(3):649-58.

226. Abele D, Burlando B, Viarengo A, Pörtner H-O. Exposure to elevated tem peratures and hydrogen peroxide elicits oxidative stress and antioxidant response in the Antarctic intertidal lim pet Nacella concinna. Com parative Biochem istry and Physiology Part B: Biochem istry and Molecular Biology. 198;120(2):425-35.

227. Prevodnik A, Gardeström J, Lilja K, Elfwing T, McDonagh B, Petrović N, et al. Oxidative stress in response to xenobiotics in the blue $\mathrm{m}$ ussel Mytilus edulis L.: Evidence for variation along a natural salinity gradient of the Baltic Sea. Aquatic Toxicology. 2007;82(1):63-71.

228. Neuhoff H-G. Influence of tem perature and salinity on food conversion and growth of different Nereis Species (Polychaeta, Annelida). Marine Ecology Progress Series. 1979;1:255-62.

229. Olive PJW. Reproduction and annual gam etogenic cycle in Nephtys hom bergii and Ncaeca (Polychaeta: Nephtyidae). Marine Biology. 1978;46(1):83-90.

230. Lawrence AJ, Soam e JM. The endocrine control of reproduction in Nereidae: a new m ultihorm onal m odel with im plications for their functional role in a changing environm ent. Philosophird Transactions of the Royal Society B: Biological Sciences. 2009;364(1534):3363-76.

231. Graf G, Bengtsson W, Diesner U, Schulz R, Theede H. Benthic response to sedim entation of a spring phytoplankton bloom : Process and budget. Marine Biology. 1982;67(2):201-8.

232. Peter JWO, Sim on WR, Ali D. Influence of photoperiod and tem perature on oocyte growth in the sem elparous polychaete Nereis (Neanthes) virens. Marine Ecology Progress Series. 1998;172:169-83.

233. Christensen M, Andersen O, Banta GT. Metabolism of pyrene by the polychaetes Nereis diversicolor and Arenicola m arina.Aquatic Toxicology. 2002;58(1-2):15-25.

234. Catalano B, Moltedo G, Martuccio G, Gastaldi L, Virno-Lam berti C, Lauria A, et al.Can Hediste diversicolor (Nereidae, Polychaete) be considered a good candidate in evaluating PAH contam ination? A m ultim arker approach. Chem osphere. 2012;86(9):87-82.

235. Jum ars PA,Dorgan KM, Lindsay SM. Diet of worm s em ended: An update of polychaete feeding gilds. Annual Review of Marine Science. 2015;7(1):497-520.

236. Ahrens MJ, Hertz J, Lam oureux EM, Lopez GR, McElroy AE, Brownawell BJ. The effect of body size on digestive chem istry and absorption efficiencies of food and sedim entbound organic contam inants in Nereis succinea (Polychaeta). Journal of Experim ental Marine Biology and Ecology. 2001;263(2):185-209.

237. Karickhoff SW, Brown DS, Scott TA. Sorption of hydrophobic pollutants on natural sedim ents. Water Research. 1979;13(3):241-8. 
238. Thom ann RV, Connolly JP, Parkerton TF. An equilibriumm odel of organic chem ical accum ulation in aquatic food webs with sedim ent interaction. Environm ental Toxicology and Chem istry. 1992;11(5):61-29.

239. McLeod PB, Luom a SN, Luthy RG. Biodynam ic m odeling of PCB uptake by Macom a balthica and Corbicula flum irea from sedim ent am ended with activated carbon. Environm ental Science \& Technology. 2008;42(2):484-90.

240. McLeod PB, van den Heuvel-Greve MJ, Luom a SN, Luthy RG. Biological uptake of polychlorinated biphenyls by Macom a balthica from sedim ent am ended witactivated carbon. Environm ental Toxicology and Chem istry. 2007;26(5):980-7.

241. Seth R, Mackay D, Muncke J. Estim ating the organic carbon partition coefficient and its variability for hydrophobic chem icals. Environm ental Science \& Technology. 1999;33(4):2390-4.

242. Schwarzenbach RP, Gschwend PM, Im boden DM. Environm ental Orgainc Chem istry: John Wiley \& Sons. 2005.

243. Høpner Petersen G. Life cycles and population dynam ics of $m$ arine benthic bivalves from the Disko Bugt area of West Greenland. Ophelia. 1978;17(1):95-120.

244. Draper NR, Sm ith H. Applied Regression Analysis: Wiley. 1981.

245. Anisim ova NA, Jørgensen LL, Lyubin PA, Manushin IE. Mapping and m onitoring of benthos in the Barents Sea and Svalbard waters: Results from the joint Russian- Norwegian benthic program m e 20062008. Institute of Marine Research - IMR. Polar Research Institute of Marine Fisheries and Oceanography - PINRO. 2010; Contract No.: 1502-8828.

246. Gogina M, Nygård H, Blom qvist M, Daunys D, Josefson AB, Kotta J, et al. The Baltic Sea scale inventory of benthic faunal com m unities. ICES Journal of Marine Science: Journal du Conseil. 2016 January 26, 2016.

247. Lovvorn JR, Cooper LW, Brooks ML, De Ruyck CC, Bum p JK, Grebm eier JM. Organic m atter pathways to zooplankton and benthos under pack ice in late winter and open water in late sum $\mathrm{m}$ er in the north central Bering Sea. Marine Ecology Progress Series. 2005;291:135-50.

248. Denisenko NV, Rachor E, Denisenko SG. Benthic Fauna of the Southern Kara Sea. In: Stein R, Fahl K, Fütterer DK, Galim ov EM, Stepanets OV, editors. Siberian river run-off in the Kara Sea: Elsevier Science B.V. 2003.

249. Strand J, Jacobsen JA, Pedersen B, Granm o Å. Butyltin com pounds in sedim ent and m olluscs from the shipping strait between Denm ark and Sweden. Environm ental Pollution. 2003;124(1):7-15.

250. Oxtoby LE, Budge SM, Iken K, O’Brien DM, Wooller MJ. Feeding ecologies of key bivalve and polychaete species in the Bering Sea as elucidated by fatty acid and com pound-specific stable isotope analyses. Marine Ecology Progress Series. 2016;557:161-75.

251. Pedersen TF. Metabolic adaptations to hypoxia of two species of polychaeta, Nephtys ciliata and Nephtys hom bergii. Journal of Com parative Physiology B. 1991;161(2):2135.

252. Decho AW, Luom a SN. Tim ecourses in the retention of food $\mathrm{m}$ aterial in the bivalves Potam ocorbula am urensis and Macom a balthica significance to the absorption of carbon and chrom ium . Marine Ecology Progress Series. 1991;78:303-14.

253. Lewis C, Galloway T. Genotoxic dam age in polychaetes: A study of species and cell-type sensitivities. Mutation Research/Genetic Toxicology and Environm ental Mutagenesis. 2008;654(1):69-75.

254. McElroy AE, Farrington JW, Teal JM. Influence of m ode of exposure and the presence of a tubiculous polychaete on the fate of benz[a]anthracene in the benthos. Environm ental Science \& Technology. 1990;24(11):1648-55. 


\section{List of references}

255. Oliver M, Desrosiers G, Caron A, Retière C. Juvenile growth of the polychaete Nereis virens feeding on a range of $m$ arine vascular and $m$ acrołgal plant sources. Marine Biology. 1996;125(4):693-9.

256. Am iardTriquet C, Berthet B. Individual Biom arkers. In: Am iardTriquet C, Am iard JC, Mouneyrac C, editors. Aquatic Ecotoxicology. 2015.

257. Esler D, Bowm an TD, Trust KA, Ballachey BE, Dean TA, Jewett SC, et al. Harlequin duck population recovery following the 'Exxon Valdez' oil spill: Progress, process and constraints. Marine Ecology Progress Series. 2002;241:271-86.

258. Eason C, O'Halloran K. Biom arkers in toxicology versus ecological risk assessm ent. Toxicology. 2002;181-182:517-21.

259. Olsen GH, Sva E, Carroll J, Cam us L, De Coen W, Sm olders R, et al.Alterations in the energy budget of Arctic benthic species exposed to oil-related com pounds. Aquatic Toxicology. 2007;83(2):85-92.

260. Cam us L, Jones MB, Børseth JF, Regoli F, Depledge MH. Heart rate, respiration and total oxyradical scavenging capacity of the Arctic spider crab, Hyas araneus, following exposure to polycyclic arom atic com pounds via sedim ent and injection. Aquatic Toxicology 2002;61(1-2):1-13.

261. Jewett SC, Dean TA, Woodin BR, Hoberg MK, Stegem an JJ. Exposure to hydrocarbons 10 years after the Exxon Valdez oil spill: evidence from cytochrom e P4501A expression and biliary FACs in nearshore dem ersal fishes. Marine Environm atal Research. 2002;54(1):21-48.

262. Payne JR, Driskell WB, Short JW, Larsen ML. Long term m onitoring for oil in the Exxon Valdez spill region. Marine Pollution Bulletin. 2008;56(12):2067-81.

263. Boehm PD, Mankiewicz PJ, Reilly JEO, Hartung R, Neff JM, Page DS, et al. Characterization of $\mathrm{m}$ ussel beds with residual oil and the risk to foraging wildlife 4 years after the Exxon valdez oil spill. Environm ental Toxicology and Chem istry. 1996;15(8):1289303.

264. Sm all GM, Burdett K, Connock MJ. A sensitive pectrophotom etric assay for peroxisom al acylCoA oxidase. Biochem ical Journal. 1985;227(1):205-10.

265. Guilherm ino L, Lopes MC, Carvalho AP, Soared AMVM. Inhibition of acetylcholinesterase activity as effect criterion in acute tests with juvenile Daphnia Magna. Chem osphere. 1996;32(4):727-38.

266. Habig WH, Pabst MJ, Jakoby WB. Glutathione S-transferases. The first enzym atic step in m ercapturic acid form ation. Journal of Biological Chem istry. 1974;249(22):71309.

267. Lowry OH, Rosebrough NJ, Lewis Farr A, Randall RJ. Protein m easurem ent with the Folin phenol reagent. Journal of Biological Chem istry. 1951;193(1):265-75.

268. Zabaleta I, Bizkarguenaga E, Prieto A, Ortiz-Zarragoitia M, Fernández LA, Zuloaga O. Sim ultaneous determ ination of perfluorinatedcom pounds and their potential precursors in $\mathrm{m}$ ussel tissue and fish $\mathrm{m}$ uscle tissue and liver sam ples by liquid chrom atographyelectrospray-tandem $\mathrm{m}$ ass spectrom etry. Journal of Chrom atography A. 2015;1387:13-23.

269. Errekatxo A, Prieto A, Zuloaga O, Usobiaga A, Etxebarria N, Fernández LA. Sim ultaneous extraction of several persistent organic pollutants in sedim ent using focused ultrasonic solid-liquid extraction. Analytical and Bioanalytical Chem istry. 2008;392(7):1471-8.

270. Leiniö S, Lehtonen KK. Seasonal variability in biom arkers in the bivalves Mytilus edulis and Macom a balthica from the northern Baltic Sea. Com parative Biochem istry and Physiology Part C: Toxicolgy \& Pharm acology. 2005;140(3-4):408-21.

271. Vidal-Liñán L, Bellas J, Etxebarria N, Nieto O, Beiras R. Glutathione S-transferase, glutathione peroxidase and acetylcholinesterase activities in m ussels transplanted to harbour areas. Science of the Total Environm ent. 2014;470-471:107-16. 
272. From ent J, Langford K, Tollefsen KE, Bråte ILN, Brooks SJ, Thom as KV. Identification of petrogenic produced water com ponents as acetylcholine esterase inhibitors. Environm ental Pollution. 2016;215:1826.

273. Bonacci S, Corsi I, Focardi S. Cholinesterases in the Antarctic scallop Adam ussium colbecki:

Characterization and sensitivity to pollutants. Ecotoxicology and Environm ental Safety. 2009;72(5):1481-8.

274. Lehtonen KK, Turja R, Budzinski H, Devier M-H. An integrated chem icabbiological study using caged m ussels (Mytilus trossulus) along a pollution gradent in the Archipelago Sea (SW Finland, Baltic Sea). Marine Environm ental Research. 2016;119(Supplem ent C):20721.

275. Baussant T, Bechm ann RK, Taban IC, Larsen BK, Tandberg AH, Bjørnstad A, et al. Enzym atic and cellular responses in relation to body burden of PAHs in bivalve m olluscs: A case study with chronic levels of North Sea and Barents Sea dispersed oil. Marine Pollution Bulletin. 2009;58(12):1796-807.

276. Giuliani ME, Benedetti M, Arukwe A, Regoli F. Transcriptional and catalytic responses of antioxidant and biotransform ation pathways in m ussels, Mytilus galloprovincialis, exposed to chem ical $\mathrm{m}$ ixtures. Aquatic Toxicology. 2013;134-135:120-7.

277. Gowland BTG, McIntosh AD, Davies IM, Moffat CF, Webster L. Im plications from a field study regarding the relationship between polycyclic arom atic hydrocarbons and glutathione S-transferase activity in m ussels. Marine Environm ental Research. 2002554(3-5):231-5.

278. González-Fernández C, Albentosa M, Sokolova I. Interactive effects of nutrition, reproductive state and pollution on m olecular stress responses of m ussels, Mytilus galloprovincialis Lam arck, 1819. Marine Environm ental Research. 2017;131:103-15.

279. Orbea A, Cajaraville MP. Peroxisom e proliferation and antioxidant enzym es in transplanted m usels of four basque estuaries with different levels of polycyclic arom atic hydrocarbon and polychlorinated biphenyl pollution. Environm ental Toxicology and Chem istry. 2006;25(6):161626.

280. Brooks S, Harm an C, Soto M, Cancio I, Glette T, Marigóm ez I. Inegrated coastal m onitoring of a gas processing plant using native and caged $\mathrm{m}$ ussels. Science of he Total Environm ent. 2012;426:375-86.

281. Cajaraville MP, Cancio I, Ibabe A, Orbea A. Peroxisom e proliferation as a biom arker in environm ental pollution assessm ent. Microscopy Research and Technique. 2003;61(2):191-202.

282. Cancio I, Ibabe A, P. Cajaraville M. Seasonal variation of peroxisom al enzym e activities and peroxisom al structure in $\mathrm{m}$ ussels Mytilus galloprovincialis and its relationship with the lipd content. Com parative Biochem istry and Physiology Part C: Pharm acology, Toxicology and Endocrinology. 1999;123(2):135-44.

283. Von Oertzen J-A. Cycles and rates of reproduction of six Baltic Sea bivalves of different zoogeographical origin. Marine Biology. 1972;14(2):143-9.

284. Livingstone DR. Biotechnology and pollution m onitoring: Use of $m$ olecular biom arkers in the aquatic environm ent. Journal of Chemical Technology \& Biotechnology. 1993;57(3):195-211.

285. Skarphéðinsdóttir H, Ericson G, Dalla Zuanna L, Gilek M. Tissue differences, dose-response relationship and persistence of DNA adducts in blue m ussels (Mytilus edulis L.) exposed to benzo[a]pyrene. Aquatic Toxicology. 2003;62(2):165-77.

286. Jenny MJ, Walton WC, Payton SL, Powers JM, Findlay RH, O'Shields B, et al. Transcriptom ic evaluation of the Am erican oyster, Crassostrea virginica, deployed during the Deepwater Horizon oil spill: Evidence of an active hydrocarbon response pathway. Marine Environm ental Research. 2016;120:166-81.

287. Carrasco Navarro V, Brozinski J-M, Leppänen MT, Honkanen JO, Kronberg L, Kukkonen JVK. Inhibition of pyrene biotransform ation by piperonyl butoxide and identification of two pyrene derivatives in Lum briculus variegatus (Oligochaeta). Environm ental Toxicology and Ghem istry. 2011;30(5):1069-78. 


\section{List of references}

288. Sim pson CD, Cullen WR, He TYT, Ikonom ou M, Reim er KJ. Metabolism of pyrene by two clam species, Mya arenaria and Protothaca stam inea.Chem osphere. 2002;49(3):315-22.

289. Díaz-Jaram illo M, Miglioranza KSB, Gonzalez M, Barón E, Monserrat JM, Eljarrat E, et al. Uptake, $\mathrm{m}$ etabolism and sublethal effects of BDE-47 in two estuarine invertebrates with different trophic positions. Environm ental Pollution. 2016;213:60817.

290. Guo R, Pan L, Lin P, Zheng L. The detoxification responses, dam age effects and bioaccum ulation in the scallop Chlam ys farreri exposed to single and $\mathrm{m}$ ixtures of benzo[a]pyrene and chrysene. Com parative Biochem istry and Physiology Part C: Toxicology \& Pharm acology. 2017;191:361.

291. Beach DG, Quilliam MA, Rouleau C, Croll RP, Hellou J. Bioaccum ulation and biotransform ation of pyrene and 1-hydroxypyrene by the $\mathrm{m}$ arine whelk Buccinum undatum . Environm ental Toxicology and Chem istry. 2010;29(4):779-88.

292. Beach DG, Quilliam MA, Hellou J. Analysis of pyrenem etabolites in m arine snails by liquid chrom atography using fluorescence and $\mathrm{m}$ ass spectrom etry detection. Journal of Chrom atography B. 2009;877(22):2142-52.

293. Neff JM, Ostazeski S, Gardiner W, Stejskal I. Effects of weathering on the toxicity of three offshore australian crude oils and a diesel fuel to m arine anim als. Environm ental Toxicology and Chem istry. 2000;19(7):1809-21.

294. Sam m arco PW, Kolian SR, Warby RAF, Bouldin JL, Subra WA, Porter SA. Distribution and concentrations of petroleum hydrocabons associated with the BP/Deepwater Horizon Oil Spill, Gulf of Mexico. Marine Pollution Bulletin. 2013;73(1):129-43

295. Helle I, Jolm a A, Venesjärvi R. Species and habitats in danger: estim ating the relative risk posed by oil spills in the northern Baltic Sea. Ecosphere. 2016;7(5):e01344-n/a.

296. Fernández-Macho J. Risk assessm ent for m arine spills along European coastlines. Marine Pollution Bulletin. 2016;113(1):200-10.

297. Laram ore S, Krebs W, Garr A. Effects ofexposure of pink shrim p, Farfantepenaeus duorarum, hrvae to Macondo Canyon 252 Crude Oil and the Corexit dispersant. Journal of Marine Science and Engineering. 2016;4(1):24.

298. Hellou J. Behavioural ecotoxicology, an "early warning” signal to assess environmental quality. Environm entalScience and Pollution Research International. 2011;18(1):1-11.

299. Zim m efFaust RK. The relationship between chem oreception and foraging behavior in crustaceans. Lim nobgy and Oceanography. 1989;34(7):1367-74.

300. Gray RH. Fish behavior and environm ental assessm ent. Environm ental Toxicology and Chem istry. 1990;9(1):53-67.

301. De Coen WM, Janssen CR. The $\mathrm{m}$ issing biom arker link: Relationships between effects on the cellular energy allocation biom arker of toxicantstressed Daphnia $\mathrm{m}$ agna and corresponding population characteristics. Environm ental Toxicology and Chem istry. 2003;22(7):163241.

302. Luís LG, Guilherm ino L. Shortterm toxic effects of naphthalene and pyrene on the com m on prawn (Palaem on serratus) assessed by a m ultiparam eter laboratorial approach: m echanism s of toxicity and im pairm ent of individual fitness. Biom arkers. 2012;17(3):27-885.

303. Tierney KB. Chem ical avoidance responses of fishes. Aquatic Toxicology. 2016;174:228-41.

304. Lotufo GR. Toxicity of sedim entassociated PAHs to an estuarine copepod: Effects on survival, feeding, reproduction and behavior. Marine Environm ental Research. 1997;44(2):149-66. 
305. Hellou J, Cheesem an K, Desnoyers E, Johnston D, Jouvenelle M-L, Leonard J, et al. A non-lethal chem ically based approach to investigate the quality of harbour sedim ents. Science of he Total Environm ent. 2008;389(1):178-87.

306. Scarlett A, Rowland SJ, Canty M, Sm ith EL, Galloway TS. Method for assessing the chronic toxicity of $\mathrm{m}$ arine and estuarine sedim entassociated contam inants using the am phipod Corophium volutator. Marine Environm ental Research. 2007;63(5):457-70.

307. Scott GR, Slom an KA. The effects of environm ental pollutants on com plex fish behaviour: integrating behavioural and physiological indicators of toxicity. Aquatic Toxicology. 2004;68(4):369-92.

308. Blocker TD, Ophir AG. Cryptic confounding com pounds: A brief consideration of the influences of anthropogenic contam inants on courtship and $\mathrm{m}$ ating behaviorActa ethologica. 2013;16(2):10.1007/s10211012-0137-x.

309. Brils JM, Huwer SL, Kater BJ, Schout PG, Harm sen J, Delvigne GAL, et al. Oil effect in freshly spiked $\mathrm{m}$ arine sedim ent on Vibrio fischeri, Corophium volutator, and Echinocardium cordatum . Environm ental Toxicology and Chem istry. 2002;21(10):2242-51.

310. Dehedin A, Piscart C, Marm onier P. Seasonal variations of the effect of tem perature on lethal and sublethal toxicities of am $\mathrm{m}$ onia for three com $\mathrm{m}$ on freshwater shredders. Chem osphere. 2013;90(3):10-122.

311. Foucreau N, Cottin D, Piscart C, Hervant F. Physiological and m etabolic responses to rising tem perature in Gam m arus pulex (Crustacea) populations living under continental or Mediterranean clim ates. Com parative Biochem istry and Physiology Part A: Molecular \& Integrative Physiology. 2014;168:6975.

312. Henry Y, Piscart C, Charles S, Colinet H. Com bined effect of tem perature and am $\mathrm{m}$ onia on $\mathrm{m}$ olecular response and survival of the freshwater crustacean Gam m arus pulex. Ecotoxicology and Environm ental Safety. 2017;137:42-8.

313. Neuparth T, Costa FO, Costa MH. Effects of tem perature and salinity on life history of the m arine am phipod Gam marus locusta. Im plications for ecotoxicological esting. Ecotoxicology. 2002;11(1):61-73.

314. Stronkhorst J, Hattum Bv. Contam inants of oncern in Dutch $\mathrm{m}$ arine harbor sedim ents. Archives of Environm ental Contam ination and Toxicology. 2003;45(3):30616.

315. Koelm ans AA, Kaag K, Sheekes A, Peeters ETHM. Triple dom ain in situ sorption m odeling of organochlorine pesticides, polychlorobiphenyls, polyarom atic hydrocarbons, polychlorinated dibenzo-p-dioxins, and polychlorinated dibenzofurans in aquatic sedim ents. Environm ental Science \& Technology. 2009;43(23):8847-53.

316. Faksness L-G, Altin D, Nordtug T, Daling PS, Hansen BH. Chem ical com parison and acute toxicity of water accom m odated fraction (WAF) of source and field collected Macondo oils from the Deepwater Horizon spill. Marine Pollution Bulletin. 2015;91(1):222-9.

317. Brown-Peterson NJ, Krasnec M, Takeshita R, Ryan CN, Griffitt KJ, Lay C, et al. A m ultiple endpoint analysis of the effects of chronic exposure to sedim ent contam inated with Deepwater Horizon oil on juvenile Southern flounder and their associated m icrobiom es. Aquatic Toxicology. 2015;165(Supplem ent C):19-209.

318. Lotufo GR, Farrar JD, Biedenbach JM, Laird JG, Krasnec MO, Lay C, et al. Effects of sedim ent am ended with Deepwater Horizon incident slick oil on the infaunal am phipod Leptocheirus plum ulosus. Marine Pollution Bulletin. 2016;109(1):253-8.

319. Hunte W, Myers RA. Phototaxis and cannibalism in gam m aridean am phipods. Marine Biology. 1984;81(1):75-9.

320. Verberk WCEP, Overgaard J, Ern R, Bayley M, Wang T, Boardm an L, et al. Does oxygen lim it therm al tolerance in arthropods? A critical review of current evidence. Com parative Biochem istry and Physibogy Part A, Molecular \& Integrative Physiology. 2016;192:6478. 


\section{List of references}

321. Sutcliffe DW. Quantitative aspects of oxygen uptake by Gam m arus (Crustacea, Am phipoda): a critical review. Freshwater Biology. 1984;14(5):443-89.

322. Vellinger C, Gism ondi E, Felten V, Rousselle P, Mehennaoui K, Parant M, et al. Single and com bined effects of cadm ium and arsenate in Gam m arus pulex (Crustacea, Am phipoda): Understanding the links between physiological and behavioural responses. Aquatic Toxicology. 2013;140-141:106-16.

323. Kaufm ann RS. Structure and function of chem oreceptors in scavenging lysianassoid an phipods. Journal of Crustacean Biology. 1994;14(1):54-71.

324. Maazouzi C, Piscart C, Legier F, Hervant F. Ecophysiological responses to temperature of the "killer shrimp" Dikerogammarus villosus: Is the invader really stronger than the native Gammarus pulex? Comparative Biochem istry and Physiology Part A: Molecular \& Integrative Physiology. 2011;159(3):26874.

325. Charron L, Geffard O, Chaum ot A, Coulaud R, Jaffal A, Gaillet V, et al. Influence of m olting and starvation on digestive enzym e activities and energy storage in Gam $m$ arus fossarum. PLOS ONE. 2014;9(4).

326. Scarlett A, Canty MN, Sm ith EL, Rowland SJ, Galloway TS. Can am phipod behavior help to predict chronic toxicity of sedim ents? Hum an and Ecological Risk Assessm ent: An International Journal. 2007;13(3):506-18.

327. Costa FO, Costa MH. Life history of the am phipod Gam m arus locusta in the Sado estuary (Portugal). Acta Oecologica. 1999;20(4):305-14.

328. Jager T, Altin D, Miljeteig C, Hansen BH. Stage-dependent and sex-dependent sensitivity to watersoluble fractions of fresh and weathered oil in the $\mathrm{m}$ arine copepod Calanus finm archicus. Environm ental Toxicology and Chem istry. 2016;35(3):72835.

329. Kolding S, Fenchel TM. Coexistence and life cycle characteristics of five species of the am phipod Genus Gam m arus. Oikos. 1979;33(2):3237.

330. Correia AD, Costa MH, Luis OJ, Livingstone DR. Age-related changes in antioxidant enzym e activities, fatty acid com position and lipid peroxidation in whole body Gam $\mathrm{m}$ arus locusta (Crustacea: Am phipoda). Journal of Experim ental Marine Biology and Ecology. 2003;289(1):83-101.

331. Gism ondi E, CossutLeguille C, Beisel JN. Do $\mathrm{m}$ ale and fem ale gam $\mathrm{m}$ arids defend them selves differently during chem ical stress? Aquatic Toxicology. 2013;140-141:432-8.

332. Welton JS, Clarke RT. Laboratory studies on the reproduction and growth of the am phipod, Gam m arus pulex (L.). Journal of Anim al Ecology. 1980;49(2):581-92.

333. Sutcliffe DW, Carrick TR, Willoughby LG. Effects of diet, body size, age and tem perature on growth rates in the am phipod Gam m arus pulex. Freshwater Biology. 1981;11(2):183214.

334. Delgado L, Guerao G, Ribera C. Effects of different salinities on juvenile growth of Gam m arus aequicauda (Malacostraca: Am phipoda). International Journal of Zoology. 2011;2011:6.

335. Dobrzycka A, Szaniawska A. The effect of salinity on osm oregulation in Corophium volutator (Pallas) and Saduria entom on (linnaeus) from the gulf of Gdańsk Oceanologia. 1995;37(1):111-22.

336. Vereshchagina KP, Lubyaga YA, Shatilina Z, Bedulina D, Gurkov A, Axenov-Gribanov DV, et al. Salinity $\mathrm{m}$ odulates therm otolerance, energy $\mathrm{m}$ etabolism and stress response in am phipods Gam $\mathrm{m}$ arus lacustris. PeerJ. 2016;4:e2657.

337. LeMiere C, Mazo J. Arctic opening: Insecurity and opportunity. Series A, editor: Routledge. 2014.

338. Aksenov Y, Popova EE, Yool A, Nurser AJG, William s TD, Bertino L, et al. On the future navigability of Arctic sea routes: High-resolution projections of the Arctic Ocean and sea ice. Marine Policy. 2017;75:30017. 
339. Forskningsrådet. Long-term effects of discharges to sea from petroleunrelated activities: The results of ten years' research. Oslo (Norway): Research Council of Norway. 2012; Contract No.: 978-82-12-03027-5.

340. Sanni S, Lyng E, Pam panin DM, Sm it MGD. II. Species sensitivity distributions based on biom arkers and whole organism responses for integrated im pact and risk assessm ent criteriaMarine Environm ental Research. 2017;127:11-23.

341. De Bruijn J, Hansen BG, Johansson S, Luotam o M, Munn SJ, Musset C, et al. Technical Guidance Docum ent on Risk Assessm ent (Part 2). European Com m ission003; EUR 20418 EN.

342. Maltby L. Environm ental Risk Assessm ent. In: Harrison RM, Hester RE, editos. Chem icals in the Environm ent: Assessing and Managing Risk. London (United Kingdom ): Royal Society of Chem istry2006.

343. Iversen PE, Lind MJ, Ersvik M, Rønning I, Skaare BB, Green AMV, et al. Guidelines for environm ental $\mathrm{m}$ onitoring of petroleum actiities on the Norwegian continental shelf (Retningslinjer for m iljøovervåking av petrolem svirksom heten til havs). Norwegian Environm ent Agenc.y2015; M-408.

344. Hylland K, Tollefsen K-E, Ruus A, Jonsson G, Sundt RC, Sanni S, et al. Water colum n m onitoringnear oil installations in the North Sea 2001-2004. Marine Pollution Bulletin. 2008;56(3):414-29.

345. Vethaak AD, Davies IM, Thain JE, Gubbins MJ, Martínez-Góm ez C, Robinson CD, et al.Integrated indicator fram ework and $m$ ethodology for $m$ onitoring and asssm ent of hazardous substances and their effects in the $\mathrm{m}$ arine environm ent. Marine Environm ental Research. 2017;124:1-20.

346. Degen R, Aune M, Bluhm BA, Cassidy C, Kędra M, Kraan C, et al. Traitbased approaches in rapidly changing ecosystem s: A roadm $\mathbf{\oplus}$ to the future polar oceans. Ecological Indicators. 2018;91:722-36.

347. Diepens NJ, Arts GHP, Brock TCM, Sm idt H, Van Den Brink PJ, Van Den HeuverGreve MJ, et al. Sedim enttoxicity testing of organic chem icals in the context of prospective risk assessment: A review. Critical Reviews in Environm ental Science and Technology. 2014;44(3):255-302.

348. Peeters ETHM, Gardeniers JJP, Koelm ans AA. Contribution of trace $m$ etals in structuring in situ $\mathrm{m}$ acroinvertebrate com $\mathrm{m}$ unity com position along a salinity gradint. Environm ental Toxicology and Chem istry. 2000;19(4):1002-10.

349. Peeters ETHM, Dewitte A, Koelm ans AA, Velden JAvd, Besten PJd. Evaluation of bioassays versus contam inant concentrations in explaining the $\mathrm{m}$ acroinvertebrate com $\mathrm{m}$ unity structure in thelRne-Meuse delta, the Netherlands. Environm ental Toxicology and Chem istry. 2001;20(12):288391.

350. Washburn TW, Reuscher MG, Montagna PA, Cooksey C, Hyland JL. Macrobenthic com m unity structure in the deep Gulf of Mexico one year after the Deepwater Horizon blowout. Deep Sea Research Part I: Oceanographic Research Papers. 2017;127:21-30.

351. Souster TA, Morley SA, Peck LS. Seasonality of oxygen consum ption in five com m on Antarctic benthic $\mathrm{m}$ arine invertebrates. Polar Biology. 2018.

352. Fernández B, Cam pilb JA, Martínez-Góm ez C, Benedicto J. Assessm ent of the m echanism s of detoxification of chem ical com pounds and antioxidant enzym es in the digestive gland of $m$ ussels, Mytilus galloprovincialis, from Mediterranean coastal sites. Chem osphere. 2012;87(11):123545.

353. Adem ollo N, Patrolecco L, Matozzo V, Marin MG, Valsecchi S, Polesello S. Clam bioaccum ulation of alkylphenols and polyciclic arom atic hydrocarbons in the Venice lagoon under different pressures. Marine Pollution Bulletin. 2017;124(1):121-9.

354. McLeod AM, Paterson G, Drouillard KG, Haffner GD. Ecological im plications of steady state and nonsteady state bioaccum uhtion models. Environm ental Science \& Technology. 2016;50(20):1110311.

355. Włodarska-Kowalczuk M, Górska B, Deja K, Morata N. Do benthic m eiofaunal and m acrofaunal com $\mathrm{m}$ unities respond to seasonality in pelagial processes in an Arctic fjord (Kongsfjorden, Spitsbergen)? Polar Biology. 2016;39(11):2115-29. 


\section{List of references}

356. Svendsen TCC, Lionel, Hargrave B, Fisk A, Muir D, C. G., Borgå K. Polyarom atic hydrocarbons, chlorinated and brom inated organic contam inants as tracers of feeding ecology in polar benthic am phipods. Marine Ecology Progress Series. 2007;337:155-64.

357. Pernet F, Trem blayR, Com eau L, Guderley H. Tem perature adaptation in two bivalve species from different therm al habitats: energetics and rem odelling of $\mathrm{m}$ em brane lipids. Journal of Experim ental Biology. 2007;210(17):2999.

358. Petersen JK, Sejr MK, Larsen JEN. Clearance rates in the Arctic bivalves Hiatella arctica and Mya sp Polar Biology. 2003;26(5):334-41.

359. Gewurtz SB, Laposa R, Gandhi N, Christensen GN, Evenset A, Gregor D, et al. A com parison of contam inant dynam ics in arctic and tem perate fish: A m odeling approh. Chem osphere. 2006;63(8):132841.

360. Sobek A, McLachlan MS, Borgå K, Asplund L, Lundstedt-Enkel K, Polder A, et al. A com parison of PCB bioaccum ulation factors between an arctic and a tem perae $m$ arine food web. Science of he Total Environm ent. 2010,408(13):2753-60.

361. Lehtonen KK, Sundelin B, Lang T, Strand J. Developm ent of tools for integrated $\mathrm{m}$ onitoring and assessm ent of hazardous substances and their biological effects in the Baltic Sea. Am bio. 2014;43(1):69-81.

362. Hanson N, Halling M, Norin H. Biom arkers for Environm ental Monitoring Suggestions for Norwegian $\mathrm{m}$ onitoring program $\mathrm{m}$ es. Miljødirektoratet2013; Contract No.: M-88.

363. Chapm an PM, Wang F, Caeiro SS. Assessing and $\mathrm{m}$ anaging sedim ent contam ination in transitional waters. Environment International. 2013;55:71-91.

364. Bocquené G, Chantereau S, Clérendeau C, Beausir E, Ménard D, Raffin B, et al. Biological effects of the "Erika" oil spill on the common mussel (Mytilus edulis). Aquatic Living Resources. 2004;17(3):309-16.

365. Broeg K, Lehtonen KK. Indices for the assessm ent of environm ental pollution of the Baltic Sea coasts: Integrated assessm ent of a m ultibiom arker approach. Marine Pollution Bulletin. 2006;53(8):508-22.

366. Frantzen M, Regoli F, Am brose Jr WG, Nahrgang J, Geraudie P, Benedetti M, et al. Biological effects of $m$ echanically and chem ically dispersed oil on the Icelandic scallop (Chlam ys islandica). Ecotoxicology and Environm ental Safety. 2016;127:95-107.

367. Geraudie P, Bakkem o R, Milinkovitch T, Thom asGuyon H. First evidence of $m$ arine diesel effects on biom arker responses in the Icelandic scallops, Chlam ys islandica. Environm ental Science and Pollution Research. 2016;23(16):16504-12.

368. Carrasco Navarro V, Leppänen MT, Kukkonen JVK, Godoy Olm os S. Trophic transfer of pyrene $\mathrm{m}$ etabolites between aquatic invertebrates. Environm ental Pollution. 2013;173:617.

369. Vethaak AD, Baggelaar PK, van Lieverloo JHM, Ariese F. Decadal trends in polycyclic arom atic hydrocarbon $(\mathrm{PAH})$ contam ination assessed by 1-hydroxypyrene in fish bile fluid in the Netherlands: Declining in $\mathrm{m}$ arine waters but still a concern in estuaries. Frontiers in Marine Science. 2016 Novem ber 11, 2016;3(215).

370. Nørregaard RD, Nielsen TG, Møller EF, Strand J, Espersen L, Møhl M. Evaluating pyrene toxicity on Arctic key copepod species Calanus hyperboreus. Ecotoxicology. 2014;23(2):163-74.

371. Sornom P, Felten V, Médoc V, Sroda S, Rousselle P, Beisel JN. Effect of gender on physiological and behavioural responses of Gam $\mathrm{m}$ arus roeseli (Crustacea Am pilpoda) to salinity and tem perature. Environm ental Pollution. 2010;158(5):1288-95.

372. Jager T, Salaberria I, Altin D, Nordtug T, Hansen BH. Modelling the dynam ics of growth, developm ent and lipid storage in the $\mathrm{m}$ arine copepod Calanus finm archicus. MarineBiology. 2017;164(1):1.

373. Węławski JM, Legeżyńska J. Life cycles of som e Arctic am phipods. Polish Polar Research. 2002;23(3 4):253-64. 


\section{List of references}

374. Legeżyńska J, Kędra M, Walkusz W. When season does not $m$ atter: sum $m$ er and winter trophic ecology of Arctic am phipods. Hydrobiologia. 2012;684(1):189-214.

375. Wiedm ann I, Reigstad M, Marquardt M, Vader A, Gabrielsen TM. Seasonality of vertical flux and sinking particle characteristics in an ice-free high arctic fjord-Different from subarctic fjords? Journal of Marine System s. 2016;154(Part B):192-205.

376. Galloway TS, Brown RJ, Browne MA, Dissanayake A, Lowe D, Jones MB, et al. Ecosystem $\mathrm{m}$ anagem ent bioindicators: the ECOMAN project- a m ultibiom arker approach to ecosystem $\mathrm{m}$ anagem ent. Marine Environm ental Research. 2004;58(2):233-7.

377. Melwani AR, Gregorio D, Jin Y, Stephenson M, Ichikawa G, Siegel E, et al. Mussel watch update: Long-term trends in selected contam inants from coastal California, 19772010. Marine Pollution Bulletin. 2014;81(2):291-302.

378. Beliaeff B, Burgeot T. Integrated biom arker response: A useful tool for ecological risk assessm ent. Environm ental Toxicology and Chem istry. 2002;21(6):131622. 


\section{Summary}

Expanding oil and gas (O\& $G$ ) and shipping activities in the absence of sufficient baseline data on the sensitivity of Arctic $m$ arine biota to oil related com pounds $m$ akes environm ental risk assessm ent for the Arctic challenging. Delayed oil weathering and biodegradation, ecological seasonal variations or a delayed $\mathrm{m}$ anifestation of toxicityin Arctic $\mathrm{m}$ arine biota could create differences between the susceptibilities of Arctic and tem perate $\mathrm{m}$ onitoring species in the long term. Such differences $\mathrm{m}$ ay be better defined in estuarine or shallow areas, where the frequent resuspension of sedim ent andstrong affinity of oil for sedim ent organic $\mathrm{m}$ atter suggest that a large proportion of oil com poundswill be transferred to the seafloor, increasing exposure of benthic organism s. Arctic benthos, and in particular sedim entdwelling organism s, can be applied as relevant and sensitive bioindicators of chem ical stress and are im portant food sources for higher trophic levels. In addition, Arctic benthic organism s m ay benefit from the projected increase in phytoplankton prim ary production under clim ate change, trengthening the pelagic-benthic coupling and trophic transfer efficiency within Arctic m arine ecosystem s. Their intrinsic ecological value calls for the evaluation and validation of oil toxicokinetic param eters in Arctic benthos as part of current oil rik assessm ent procedures and m onitoring program $m$ es. Such knowledge $m$ ay form an im portant basis for the selection of relevant Arctic benthic bioindicators of long-term environm ental im pacts of O\& $\mathrm{G}$ and shipping activities.

The aim of this thesis is to developa suite of candidate exposure m ethods, including bioaccum ulation and biochem ical $\mathrm{m}$ arkers, for the identification of bioindicators of chem ical stress derived from $O \& \mathrm{G}$ and shipping in Arctic coastabenthic system s. The second aim is to propose, based on experim ents with tem perate species, the avoidance of oil contam inated sedim ent by Arctic benthic am phipods as an oil risk assessm ent tool for the Arctic.

In Chapter 2, the applicability of biota-sedim ent accum ulation factors (BSAFs) as chem ical exposure m etic was evaluated in three representative species of an Arctic coastal benthic system under field conditions. In a prelim inary round, target species were selected based on their feeding $m$ ode, reduced $m$ otility and relative abundance. Two bivalves, the susperion feeder (Astarte borealis) and the surface deposit and suspension feeder (Macoma calcarea), and one polychaete, the predator and deposit feeder (Nephtys ciliata), were selected. These species and corresponding sedim ent sam ples were collected at a refeence area (Blom strandhalvøya) and a relatively oil im pacted area (NyÅlesund) to study the influence of 


\section{Summary}

local sedim ent com ponents on the bioaccum ulation of polycyclic arom atic hydrocarbons (PAHs), polychlorinated biphenyls (PCBs) and hexachlorobenzene (HCB).

Bioaccum ulation differences were detected between both areas for PAHs, with higher 10-90th $\sum{ }_{13}$ PAH BSAF percentiles (i.e., 0.35 - 5.50) in Blom strandhalvøya than in $\mathrm{Ny}$ Ålesund organism s (i.e., $0.00-0.07$ ). Differences in the quality of organic $\mathrm{m}$ atter in sedim ent and other food item s probably affected the sedim ent ingestion and thus, PAH uptake by organism $\mathrm{s}$ from different areas. However, sim ilar patterns across sam pling areas were observed im. calcarea based on $\sum{ }_{13} \mathrm{PAH}$ body residues, with higher lipid-norm alisedconcentrations in NyÅlesund specim ens. This pointed at possible differences in toxicokinetic param eters such as PAH uptake and elim ination, and higher preference for biogenic organic $\mathrm{m}$ atter sources for $M$. calcarea as com pared to the other species. It was concluded that PAH body residues provide a $\mathrm{m}$ ore realistic estim ate of the bioaccessible PAH fraction since their variability am ong individuals and environm ental conditions was lower than for BSAFs. The study also reflected on the necessity to include black carbon as a $\mathrm{m}$ ajor influencing factor of sedim ent exposure to persistent organic contam inants for Arctic benthos.

In Chapter 3, the relative im portance of feeding traits and sedim ent com position for the bioaccum ulation of PAHs by the aforem entined species was evaluated using a dynam ic $\mathrm{m}$ odelling approach. Modelling input data were obtained from a laboratory exposure experim ent perform ed with specim ens collected at Blom strandhalvøya. The experim ent followed the design of an earlier exposure experim ent developed for tem perate counterpart species for com parison purposes. The latter included the surface deposit and suspension feeding bivalve (Limecola balthica) and the deposit feeding polychaete (Alitta virens) frequently used as test species in bioaccum ulation studies. In both experim ents, species were exposed to sedim ent treatm ents $m$ ade from the com bination of different ratios of a reference and a naturally contam inated sedim ent collected in a tem perate estuary. In this laboratory study, PAH body residues were again selected as the $\mathrm{m}$ ost suitable exposure $\mathrm{m}$ etric due to considerable BSAF variability in both the control and exposed groups.

In the Arctic experim ent, differences in the bioavailability of PAHs between sedim ent treatm ents for each taxonom ygroup possibly explained significantly higher lipid-norm alised concentrations observed for 3- and 4-ring PAHs in A. borealis com pared toN. ciliata. However, PAH uptake was lim ited am ong bivalve species which was likely caused by the presence of pyrogenic PAH sources in the contam inated sedim ent, com m only associated with 
black carbon em issions from shipping, and low nutritional value of the bivalves reference sedim ent. The experim ental approach used did not reduce the uncertainty in the relative contribution of different PAH sources to body residues observed in Chapter 2. It was concluded that future studies should look at the influence of the quality and quantity of organic $\mathrm{m}$ atter in different sedim ent PAH sources to help to interpret chem ical exposure in Arctic species.

A com parison with the tem perate experim ent did not yield any significant differences in PAH body residues nor m easured BSAFs between the Arctic and tem perate counterpart species. Sim ilar exposure routes and the considerable biological varibility in the control groups could explain the sim ilarity in the m odel output between experim ents, also reflected by the absence of differences in the $\mathrm{m}$ odel param eters between test species or experim ents. Because of lim itations on the availability of Arcic species and the variability observed during exposure, the m odelling approach did not provide any insightful inform ation on the bioaccum ulation $m$ echanism s. Nevertheless, it is expected that such constraints $m$ ay be overcom e after further characterization of PAH uptake and elim ination routes in Arctic species under local conditions.

In Chapter 4, a suite of biom arkers of PAH exposure (acylCoA oxidase, AOX; glutathione S-transferase, GST; pyrene m etabolites) andneurotoxicity (acetylcholinesterase, AChE) were analysed in the aforem entioned species in order to evaluate the speciesspecific sensitivity of Arctic species to PAHs in com parison to their tem perate counterparts and the general applicability of standard biom arker protocols for predicting sublethal ecological effects in Arctic species. Due to lim ited sam ple availability and general lack of knowledge of PAH biotransform ation pathways am ong $\mathrm{m}$ arine invertebrates, enzym atic biom arkers (i.eAOX, AChE, GST) were analysed in A. borealis sam ples collectedfrom experim ents included in Chapter 3, whereas pyrene $m$ etabolites were analysed in sam ples from Arctici(f. calcarea, N. ciliata) and tem perate species (L. balthica, A. virens).

The results of the study showed neither induction or correlation between the activity of AOX or GST in A. borealis and PAH contam ination levels in sedim ent treatm ents, nor evidence of PAH neurotoxicity according to AChE activity. Lack of enzym atic induction $\mathrm{m}$ ay be related to either too low PAH concentrations in sedim ent or to the nfluence of confounding factors such as low food availability or changing $m$ etabolic status of A.borealis during sam pling. Pyrene biotransform ation rates were lim ited am ong Arctic and tem perate species as the ratio 


\section{Summary}

of pyrene-1-glucuronide (Phase II m etabolte) to pyrene content did not correlate with pyrene exposure in test organism $\mathrm{s}$. It was concluded that PAH $\mathrm{m}$ etabolites $\mathrm{m}$ ay be used to estim ate PAH exposure as a flux balance between PAH parental and m etabolite com pounds, although Phase II biotransform ationpathways need further characterization in test species.

In Chapter 5, the avoidance response to sedim ent contam inated with Distillate Marine grade A (DMA) oil of a freshwater (Gammarus pulex) and m arine (Gammarus locusta) m odel benthic species was evaluated in a 96-h test period and used as the basis for future pilot testing in Arctic species. G. pulex avoided contam inated sedim ent at the highest concentration (1000 m g DMA/kg dry wt.), while G. locusta avoidance was either not consistent with exposure tim e or below effect threshold. Lack of consistency in G. locusta avoidance was possibly caused by differences in the energy allocation to growth and reproduction between G. locusta life-span stages, affecting their ability to escape from DMA. In contrast, a bwer reproductive effort in G. pulex winter individuals $\mathrm{m}$ ay have increased their energy storage capacity and thus, energy allocation to avoidance. In addition, differences in DMA behaviour between freshwater and $\mathrm{m}$ arine tests and $\mathrm{PAH}$ partitioning between $\mathrm{m}$ aine tests likely affected the com parability between tests.

The results of this study highlighted the need for baseline assessm ents of interindividual variability in the avoidance response of benthic am phipods as well as the chem ical characterization of sedim ent treatm ents and overlying water in exposure system $\mathrm{s}$. It was concluded that the com bined analysis of energy consum ption and spatial avoidance could help to elucidate whether the avoidance ability of am phipods $m$ ay be affected by their reproductive strategy and how could avoidance be translated into a recognizable pattern of effects on lifehistory traits of Gammarus spp. Future studies should consider as well the influence of reproductive and m oulting stage on the sensitivity to oil of benthic am phipds.

The final Chapter (6) sum $m$ arizes and discusses the outcom es of Chapters $\mathbb{Z} 05$ in order to select the $\mathrm{m}$ ost appropriate approach to risk identification of $\mathrm{O} \& \mathrm{G}$ and shipping activities in Arctic benthos and to identify research priorities for the validation of candidate m ethods. Recom $\mathrm{m}$ endations for the selection and validation of bioindicators and biom arkers of long term oil spill and O\& G environm ental effects in Arctic coastabenthic system s included (1) the im plem entation of $m$ ore standardized $m$ ethods foedim ent preparation, exposure conditions and acclim atization of field organism $\mathrm{s}(2)$ the collection of baseline data on PAH body residues and biom arker responsesin Arctic bioindicator species, (3) the characterization 


\section{Summary}

of quality and quantity of organic $m$ atter in all different diet com ponentsof exposure treatm ents (4) the evaluation of the relative effect of environm ental and biological factors on the activity of biom arkers (5) the design of com m unity assessm ents to explore the relationship between PAH body residues, sedim ent characteristics andenvironm ental factors and (6) the inclusion of oil avoidance tests using Arctic benthic am phipodsas a candidate tool for oil spill risk assessm ent for the Arctic. This work contributes to the developm ent of Actic benthic bioindicators of the cum ulative effects of $O \& G$ and shipping activities through the identification of robust PAH exposure m etrics in representative benthic species of the Barents Sea region. 


\section{Acknowledgements}

First of all, I would like to thank all $\mathrm{m}$ y predecessors who $\mathrm{m}$ ade it possible to launch the ARCIND project. From the $\mathrm{m}$ om ent I learned that this could be $\mathrm{m} y$ next endeavor, I accepted your offer with great joy and felt im m ediately supported.

Martine, you were $\mathrm{m}$ y beacon, so to speak, duing $\mathrm{m}$ y first halfyear at Wageningen Marine Research. Thanks to your enthusiasm and determ ination all the seem ingly insurm ountable obstacles of our first season in Svalbard vanished like $\mathrm{m}$ ist, and the hard work in preparation for and during our stay on the island really paid off. I hope we will keep in touch and rem ain in the quest for a sustainable Arctic.

Nico, I often wonder how everything would have looked if we had had you on board during our fieldwork. H.D. Thoreau once claim ed that you cannot sit down to write when you have not stood up to live. Som ehow you can only grasp his lesson if tedious labwork leads to having a casual Skype chat about snow's absorbing effect on noise, or how to release a penguin from custom s clearance. Thanks for sharing yourinsight and $m$ irth with the TOX people.

Bart, I am particularly grateful to you for your patience during our papers and thesis writing. I could not have reached this point without your help. You were always available for a chat - I think we $m$ ay have set therecord for the longest supervisor-student talk! - and always brought your positive attitude with you, even if everything seem ed lost. It helped keep m e selfassured during this long battle.

I would like to dedicate som e words to (ex-)AEW people, a great bunch of scientists! Noël and Jacqueline, I am so thankful for your unconditional support and friendship. I am sure we will com e across each other again, and will probably look back on this $\mathrm{PhD}$ with a sense of nostalgia.

Ana Isabel, you were $\mathrm{m}$ y ray of sunhine during $\mathrm{m}$ y first year in Wageningen, and together with Iñaki we built a sm ashingly effective gang!

Big kudos to our technician Frits, who also helped m e ship working $m$ aterials and sam ples within the Netherlands and back and forth between the Netherlands, Svalbard and the Basque Country, and to our form er students Tineke, Chenwen and Joris for their hard work and dedication. 


\section{Acknowledgements}

My gratitude goes as well to the group of form er and current AEW PhDs: Jelle, Marlies, Arie, Bernardo, Bregje, Andreu, Jugk, Annelies, Ingrid, Els, Paula, Merel, Hazi, Babak, Usm an, Maíra, Sanne, Pablo; and staff m em bers: Marten, Egbert, Sebastian, Jeroen, Edwin, Nancy, Petra, Wendy and John. Being part of this com m unity and the Wageningse neighbourhood would certainly not have been as enriching as it was without all of you!

Alba and Maria, thanks for helping $m$ e capture the beauty of the lab surroundings when fatigue appeared. Both the Bay of Plentzia in Biscay (Spain) and the Bay of Kongsfjorden in Svalbard will occupy a special place in $\mathrm{m}$ y heart, and you are a part of that $\mathrm{m}$ agnificent picture.

As for the last part, I would like to say infinitas gracias to $\mathrm{m} y$ fantastic fam ily, especially to $\mathrm{m}$ y parents, Gloria and Ricardo, who often bore the weight of this endless and $\mathrm{m}$ uddy track called $\mathrm{PhD}$. We will see each other soon, this tim e up in the Arctic Circle!

Quiero tam bién agradecer todo su apoyo a la fam ilia de los Ciordia y los Corres que andam os desperdigados por España y expandiéndonos a otros rincones del m undo.

Y a m i pequeño pero tam bién gran herm ano, Kordian, con quien espero que podam os seguir siem pre teniendo nuestras conversaciones en fam ilia;Nunca pierdas tu esencia!

How do people imagine the landscapes they find themselves in? How does the land shape the imaginations of the people who dwell in it?

How does desire itself, the desire to comprehend, shape knowledge? - Barry Lopez - 


\section{Curriculum vitae}

Ariadna S. Szczybelski Ciordia (Zaragoza, Spain, April 2nd 1985) obtained her BSc degree in Biology from the University of Alicante, Spain. During her studies, she was acquainted with several $\mathrm{m}$ arine biology aspects and com pleted an Erasm us exchangat the University of Liège (Belgium ) where she becam e interested in the subject of $m$ arine ecotoxicology and related research perform ed therein. In 2010, she decided to enrol on an MSc program m e in Environm ental Contam ination and Toxicology (University of Valencia, Spain). She focused on the use of biochem ical biom arkers in freshwater and $\mathrm{m}$ arine fish specieso $\mathrm{m}$ onitor effects of organic pollution and did an internship at the Institute of Marine Sciences (ICMCSIC) in Barcelona, Spain. After finishing her MSc degree, she was awarded a Leonardo Da Vinci fund to com plete a $6 \mathrm{~m}$ onth workrelated training at the Ecotoxicology laboratory of IFREMER (Nantes, France). During her stay she was involved in the analysis of $m$ arine fish and shellfish sam ples fromtwo projects funded by the French National Agency for Research (CONPHYPOP and GIMEPEC) and in the sam pling of flatfish speciesin the Seine estuary (France) as part of the BIOCO 2012 cam paign.After finishing her internship, she started a $\mathrm{PhD}$ in the Aquatic Ecology and Water Quality Managem ent Group in Wageningen University (Wageningen, the Netherlands). The $\mathrm{PhD}$ revised the applicability of exposure assessm ent $m$ ethods to oil related com pounds in Arctic and tem peratenthic $\mathrm{m}$ acroinvertebratesfor the selection of relevant Arctic benthic bioindicators to be used in current environm ental risk assessm ent procedures in the Arctic. During her $\mathrm{PhD}$ shecosupervised one BSc student and three MSc students, presented at two international conferences (ARCTIC FRONTIERS and SETAC Europe) and was m em ber of the Dutch National Com m ittee of the Association of Polar Early Career Scientists (APECS) in 2016 2017. She is currently taking her second MSc program m e in Marine Biotechnology atthe University of Trom sø (Trom sø, Norway)with an eye to studying different strategies for optim izing oil biorem ediationin Arctic m arine sedim ents. 


\section{List of publications}

Szczybelski A.S., M.J. van den Heuvel-Greve, A.A. Koelm ans N.W. van den Brink. Subm itted. Biom arker responses and biotransform ation capacity in Arctic and tem perate benthic species exposed to polycyclic arom atic hydrocarbons Science of the Total Environm ent.

Szczybelski A.S., N.J. Diepens, M.J. van den Heuvel-Greve, N.W. van den Brink, A.A. Koelm ans Under revision. Bioaccum ulation of polycyclic arom atic hydrocarbons by Arctic and tem perate benthic species Environm ental Toxicology and Chem istry.

Szczybelski, A.S., T. Kam pen, J. Vrom ans, E.T.H.M. Peeters, M.J. van den HeuvelGreve, N.W. van den Brink, A.A. Koelm ans (2018).Avoidance tests as a tool to detect sublethal effects of oil-im pacted sedim entsEnvironm ental Toxicology and Chem istry 37(6), 1757 1766.

Szczybelski, A.S., M.J. van den Heuvel-Greve, T. Kam pen C. Wang, N.W. van den Brink, A.A. Koelm ans (2016). Bioaccum ulation of polycyclic arom atic hydrocarbons, polychlorinated biphenyls and hexachlorobenzene by three Arctic benthic species from Kongsfjorden (Svalbard, Norway). Marine Pollution Bulletin 112(1-2), 65-74.

Van den Heuvel-Greve, M.J., A.S. Szczybelski, N.W. van den Brink, M.J.J. Kotterm an, C.J.A.F. Kwadijk, A. Evenset, A.J. Murk (2016). Low organotin contam ination of harbour sedim ent in Svalbard Polar Biology 39(10), 1699-1709.

Akcha, F., A. Barranger, E. Bachère, C. Heude Berthelin, D. Piquem al, P. Alonso, R. Rondon Sallan, G. Dim astrogiovanni, C. Porte, D. Menard,A. Szczybelski, A. Benabdelm ouna, M. Auffret, J. Rouxel, T. Burgeot (2016). Effects of an environm entally relevant concentration of diuron on oyster genitors during gam etogenesis: responses of early $\mathrm{m}$ olecular and cellular $\mathrm{m}$ arkers and physiological im pactsEnvironm ental Science and Pollution Research 23(8), 8008-8020. 


\section{SENSE Diploma}

\section{SENSE}

Netherlands Research School for the

Socio-Economic and Natural Sciences of the Environment

\section{I P L O M A}

\section{For specialised PhD training}

The Netherlands Research School for the Socio-Economic and Natural Sciences of the Environment

(SENSE) declares that

\section{Ariadna Sabina Szczybelski Ciordia}

born on 2 April 1985 in Zaragoza, Spain

has successfully fulfilled all requirements of the

Educational Programme of SENSE.

Wageningen, 5 November 2018

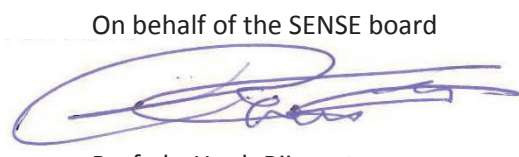

Prof. dr. Huub Rijnaarts

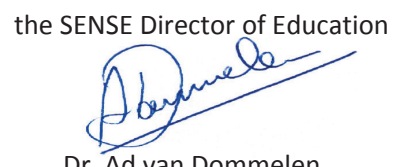

Dr. Ad van Dommelen

The SENSE Research School has been accredited by the Royal Netherlands Academy of Arts and Sciences (KNAW)

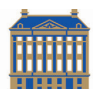

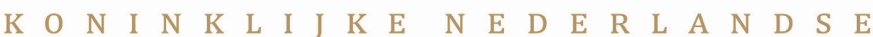

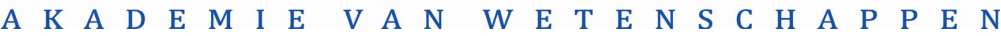




\section{SENSE Diploma}

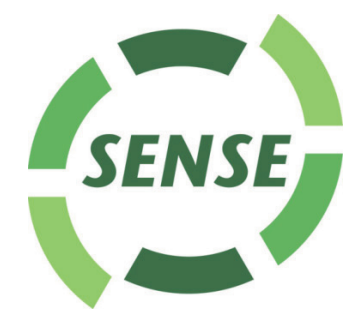

The SENSE Research School declares that Ariadna Sabina Szczybelski Ciordia has successfully fulfilled all requirements of the Educational PhD Programme of SENSE with a work load of $34.9 \mathrm{EC}$, including the following activities:

\section{SENSE PhD Courses}

- Environmental research in context (2013)

- Research in context activity: 'Preparing and organizing of Netherlands / Belgium Symposium for Association of Polar Early Career Scientists, APECS (2 November 2016)'

\section{Selection of Other PhD and Advanced MSc Courses}

\section{External training at a foreign research institute}

- Enzymatic determination of a suite of exposure biomarkers, PIE Research Centre, University of the Basque Country, Spain (2015)

\section{Management and Didactic Skills Training}

- Supervising two MSc students with theses entitled 'Avoidance of DMA contaminated sediment by Gammarus pulex' (2014) and 'Bioaccumulation of polycyclic aromatic hydrocarbons (PAHs) and polychlorinated biphenyls (PCBs) in the Arctic Ocean' (2015)

o Teaching in the BSc course 'Environmental Toxicology' (2014-2015)

\section{Oral Presentations}

- ARCIND - Development of ARCtic biological INDicators for the impact assessment of (new) human activities in the Arctic ecosystem. NWO Symposium 2014, 5 November 2014, The Hague, The Netherlands

- Biological indicators for the impact assessment of (new) human activities in the Arctic. SETAC Europe, 7 May 2015, Barcelona, Spain

- Biological indicators for the impact assessment of (new) human activities in the Arctic. APECS Netherlands Symposium, 6 November 2015, The Hague, The Netherlands

SENSE Coordinator PhD Education

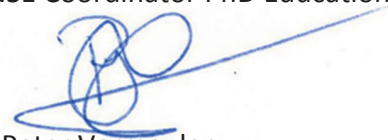

Dr. Peter Vermeulen 
The research described in this thesis was financially supported by Equinor ASA (fka Statoil ASA) and the Wageningen UR TripleP@Sea innovation program m e.

Financial support from the Aquatic Ecology and Water Quality Managem ent Group at Wageningen University for printing this thesis is gratefully acknowledged.

Cover art: Nancy Cam pbell

Akunnagaa, 2011

How To Say 'I Love You' In Greenlandic: An Arctic Alphabet

Bird Editions, Oxford: 2011

Printed by: DigiForce $\|$ ProefschriftMaken 


\section{Propositions}

1. Mechanistic bioaccumulation models for Arctic coastal benthic systems should account for the relative proportion of terrestrial dissolved organic matter and marine dissolved organic matter and its change over time.

(this thesis)

2. The variation in bioaccumulation by Arctic benthic macroinvertebrates can largely be explained by site-specific differences in diet choice and food composition.

(this thesis)

3. Community initiatives to promote physical activity and strength training among pre-frail older adults can significantly reduce health care and social assistance spending.

J. Sacha, M. Sacha, J. Soboń, Z. Borysiuk and P. Feusette (2017). "Is It Tim e to Begin a Public Cam paign Concerning Frailty and Pre-frailty? A Review Article." Frontiers in Physiology 8(484)

4. Geospatial data visualization should be used in decision making about climate change risks to define and communicate extreme events.

5. In the era of political micro-targeting and mass surveillance, our digital footprint can obstruct a functioning democracy.

6. Closing the gender pay gap begins by introducing a universal basic income.

Propositions belonging to the thesis, entitled

'Advancem ent of benthic indicators and biom arkerbased tools for biomonitoring and risk assessm ent in the Barents Sea region'

Ariadna S. Szczybelski Ciordia

Wageningen, 5 November 2018 